\title{
The Russian State and Russian Energy Companies, 1992-2018
}

The Russian State and Russian Energy Companies analyses the development of relations between the state and five major energy companies, and how this shaped Russia's foreign policy in the post-Soviet region. The book argues that the development of Russia's political economy mattered for foreign policy over the quarter of a century from 1992 to 2018. Energy companies' roles in institutional development enabled them to influence foreign policy formation, and they became available as tools to implement foreign policy. The extent to which it happened for each company varied with their accessibility to the Russian state. Institutional development increased state capacity, in a way that strengthened Russia's political regime. The book shows how the combined power of several companies in the gas, oil, electricity, and nuclear energy industry was a key feature of Russian foreign policy, both in bilateral relationships and in support of Russia's regional position. In this way, Russia's energy resources were converted to regional influence. The book contributes to our understanding of Russia's political economy and its influence on foreign policy, and of the formation of policy towards post-Soviet states.

Ingerid M. Opdahl is associate professor at the Norwegian Institute for Defence Studies (IFS) at the Norwegian Defence University College, and heads the IFS's Russian Security and Defence Programme. She obtained a $\mathrm{PhD}$ in Russian, European and Eurasian Studies from the University of Birmingham in 2016. Opdahl has earlier published on Russia's relations with Georgia and with Central Asian states. Her current research is part of the international research project Russia's Politicized Economy, Elite Dynamics and the Domestic-Foreign Policy Nexus (RUSECOPOL), funded by the Norwegian Research Council and led by the IFS. 


\section{BASEES/Routledge Series on Russian and East European Studies}

\section{Series editors:}

sociology and anthropology: Judith Pallot (President of BASEES and Chair), University of Oxford economics and business: Richard Connolly, University of Birmingham media and cultural studies: Birgit Beumers, University of Aberystwyth politics and international relations: Andrew Wilson, School of Slavonic and East European Studies, University College London history: Matt Rendle, University of Exeter

This series is published on behalf of BASEES (the British Association for Slavonic and East European Studies). The series comprises original, highquality, research-level work by both new and established scholars on all aspects of Russian, Soviet, post-Soviet and East European Studies in humanities and social science subjects

128. Security, Society and the State in the Caucasus

Edited by Kevork Oskanian and Derek Averre

129. Memory, the City and the Legacy of World War II in East Central Europe The Ghosts of Others

Uilleam Blacker

\section{US Foreign Policy Towards Russia in the Post-Cold War Era} Ideational Legacies and Institutionalised Conflict and Co-operation David Parker

\section{Tolstoy's Political Thought}

Christian Anarcho-Pacifist Iconoclasm Then and Now

Alexandre Christoyannopoulos

\section{Azerbaijan and the European Union}

Eske Van Gils

\section{Freedom of Expression in Russia's New Mediasphere}

Edited by Mariëlle Wijermars and Katja Lehtisaaris

134. The Russian State and Russian Energy Companies, 1992-2018 Ingerid M. Opdahl

For a full list of available titles please visit: https://www.routledge.com/BASEESRoutledge-Serieson-Russian-and-East-European-Studies/book-series/BASEES 


\section{The Russian State and Russian Energy Companies, 1992-2018}

Ingerid M. Opdahl 
First published 2020

by Routledge

52 Vanderbilt Avenue, New York, NY 10017

and by Routledge

2 Park Square, Milton Park, Abingdon, Oxon OX14 4RN

Routledge is an imprint of the Taylor \& Francis Group, an informa business

(C) 2020 Taylor \& Francis

The right of Ingerid M. Opdahl to be identified as author of this work has been asserted by him in accordance with sections 77 and 78 of the Copyright, Designs and Patents Act 1988.

All rights reserved. No part of this book may be reprinted or reproduced or utilised in any form or by any electronic, mechanical, or other means, now known or hereafter invented, including photocopying and recording, or in any information storage or retrieval system, without permission in writing from the publishers.

Trademark notice: Product or corporate names may be trademarks or registered trademarks, and are used only for identification and explanation without intent to infringe.

British Library Cataloguing-in-Publication Data

A catalogue record for this book is available from the British Library

Library of Congress Cataloging-in-Publication Data

A catalog record has been requested for this book

ISBN: 978-1-351-13407-1 (ebk)

ISBN: 978-0-815-35405-5 (hbk)

Typeset in Times New Roman

by Taylor \& Francis Books 


\section{Contents}

List of illustrations vi vi

Preface and acknowledgements vii

Note on translation and transliteration xiii

Abbreviations and acronyms xiv

1 Introduction: Energy and the institutional development of the Russian state 1

2 Energy and Russia's foreign policy towards post-Soviet states 22

3 The electricity industry: RAO UES and Inter RAO 42

4 The nuclear energy industry: Minatom/Rosatom 90

5 The oil industry: Lukoil 143

6 The oil industry: Transneft and pipeline transport 196

7 The gas industry: Gazprom 257

8 Conclusion: Political economy and foreign policy 315

$\begin{array}{ll}\text { Index } & 325\end{array}$ 


\section{Illustrations}

\section{Figures}

6.1 Map of oil pipelines of Transneft 198

7.1 Map of selected gas trunk pipelines in Russia and eastern Europe 259

\section{Tables}

3.1 Accumulated electricity debts to Russia, 1998-2000 47

3.2 Non-payment and barter in Russia's electricity trade, 1998-2001 48

3.3 Inter RAO's investments in CIS member states 59

6.1 Selected Transneft proposed and completed pipeline projects in Russia and abroad 208

6.2 Transneft share of Russian crude oil export, 2004-2017 214

6.3 Dividends and taxes paid by Transneft, 2001-2018 220

6.4 Transneft's charity donations and sponsorships, 2005-2017 224

7.1 Gazprom's sales to post-Soviet states, 2002-2018 273 


\section{Preface and acknowledgements}

The young company president was barricaded in his Moscow office, the building surrounded by special police. When they went in early the next morning, to force him to give up his position in favour of a politically desirable replacement, media reported that the office door was opened using an angle grinder. ${ }^{1}$ The stand-off ended with the entry of the new company president. While the outgoing had been known for his audacity, his successor was an experienced and adept industry executive. Over the next eight years, he skilfully expanded the business while giving the occasional memorable media statement. Both are now long gone from Transneft, the Russian oil pipeline monopoly. It has since been headed by a loyal, and far less colourful, manager with a similar background to President Vladimir Putin. Conflicts over company management in Transneft and other energy companies are now more low-key, even when dramatic. They involve documents, delaying tactics and the occasional charge of fraud or embezzlement, rather than office sieges broken by police wielding power tools. What has not changed is that the outcome of such conflicts impacts Russian politics and influences institutional change in the economy. After all, they involve control over resource streams - money flows - and relations between the state and energy companies remain crucial in the Russian political economy. This book shows how state-business relations in Russia have developed and made energy companies so important, to the extent that they even became foreign policy tools of the state.

State-company relations are crucial in any political economy, not just Russia's. This is especially the case when the rules of the game change. When every new rule has the potential to upset all short-term plans and long-term strategies, elites make their best effort to control decisive positions, as they did in post-Soviet Russia from 1992 to 2018. Even so, and even in periods of rapid change, the institutions, the rules of the game, evolve more slowly. The scope of this book is a consequence of the theoretical perspective on institutional development. Empirical realities also mattered for the design. The end of the Soviet Union was the beginning of the contemporary post-Soviet states. The centrifugal changes that followed have gradually turned the states into different political entities. It is meaningless to analyse them applying a onesize-fits-all approach. Nevertheless, Russia's energy relations with them 
exhibit many continuities. Some ties have lost their relevance, whereas others have enhanced their significance. Covering a long time period makes it possible to show how and to arrive at a more complete picture.

Overall social order development here is understood as providing a frame for institutional transformation. Institutions, the rules, regulations and customs that structure relations between actors like companies and ministries, and individuals, are fundamental bricks in any political economy. The concept of the limited access order, where political and economic power are united, and rules are enforced according to principles of privilege and not of impersonal rights, is the starting point. This is highly relevant in Russia today, where privileges are decisive, and political and economic power go hand in hand. Institutional development emphasises the general traits of the Russian political economy, even as three of the five cases of state-business relations belong to the petroleum industry, and all five to the energy industries more generally. I also argue that Russia's institutional development impacted foreign policy towards other post-Soviet states. Domestic institutions enabled Russian policymakers to use company operations as foreign policy tools.

The Russian political economy and its influence on foreign policy come under scrutiny here. The book embeds five cases of state-company relations in the energy industries. Perhaps unsurprisingly, Gazprom is included. Few energy companies have mattered as much in foreign policy. But it is not the only company of importance. In the electricity industry, the vertically integrated monopoly RAO UES (to 2008) and its former subsidiary for foreign operations, Inter RAO, played a similar role to Gazprom's in gas. The nuclear energy industry, organised first under the umbrella of the Nuclear Industry Ministry Minatom, later restructured into the state corporation Rosatom, was central in relations with Ukraine and Kazakhstan. At home, its trajectory epitomises many of the challenges of monopolies and their relations with the state. Lukoil is one of Russia's largest oil companies, a pioneer of the industry and central to the state's relations with the industry. It has long had substantial operations in the post-Soviet region. Transneft represents another side of the oil industry, pipeline transport, which has been singularly important for state power, also in relation to Russia's post-Soviet neighbours. The energy industries' integrated infrastructure extended across the post-Soviet region: gas, oil, electricity and nuclear energy, and the companies here were all at first closely related to the state. The changes that followed in the institutional framework for each industry to some extent propelled them away from the state, at very different speeds. One company, Lukoil, is now privately owned. Transneft, Gazprom and Inter RAO have minority shareholders, while a majority is held by the state, although ownership is exercised in very different ways. Rosatom is organised as a state corporation, and holds a more autonomous position in relation to the state. But regardless of the differences to the formal institutional set-up, their institutional trajectories display considerable similarities. Moreover, as this book will show, they all depended on their relations with the Russian state to conduct business operations in the post-Soviet region. 
This book was written with a diverse audience in mind. It comprises eight chapters, five of which contain case studies. They can be read on their own, if the aim is to gain some insight into only one company and its relations with the state. Nevertheless, I encourage scholars, practitioners and students alike to read much of the book. The five case chapters complement each other. The similarities between gas and the nuclear energy industry and their relations with the state, or the complementarity of gas relations, electricity relations and nuclear energy relations in Russian foreign policy, can best be appreciated by reading more than one case chapter. Together, they illuminate a greater range of state-company relations than an exclusive focus on gas, or gas and oil, would have permitted. This breadth of approach has yielded the book's original contribution, that it looks at the variety of Russia's foreign policy tools and explains how the domestic political economy made them accessible to the state.

The case chapters are preceded by two introductory chapters. Chapter 1 takes as a starting point the central role of state-company relations in bringing about institutional change, on the background of Russia's state of development in the early 1990s. Concepts used in the book, such as informality and formality, rents, and state capacity, are defined and discussed, as are the most relevant characteristics of the Russian elite with regard to the analysis here. The break-up of the Soviet Union led to institutional weakness and a state of flux. The energy companies filled central functions in the political economy, making them important also with regard to other post-Soviet states.

Chapter 2 places Russia's energy policy towards post-Soviet states in the context of overall Russian foreign policy in the years 1992-2018. Russian foreign policy from the mid-1990s gradually saw regional integration processes in terms of the possibilities for Russia to dominate. In the beginning, the approach coexisted with a reality of weakening Russian influence in the region. After the turn of the century, continued asymmetric energy dependence, access to more resources, and a greater demand for Russian involvement increased Russia's overall leverage. But as the 2000s progressed, contradictions emerged between Russia's coercive use of foreign economic relations and the pursuit of more cooperative regional integration. This process came to a head with the annexation of Crimea: the repercussions limit Russia's regional power to this day.

The case chapters, Chapter 3 through 7, contain analyses of one company's relations with the state, both at home and with regard to operations in the post-Soviet Union, from 1992 to 2018. The company is introduced, and industry characteristics outlined. The company's overall, predominantly domestic, relations with the state are analysed first for each time period. This is followed by discussion of the relationship over foreign operations and foreign policy.

The non-hydrocarbon companies, RAO UES/Inter RAO and Minatom/ Rosatom, are discussed before the companies of the oil and gas industries, Lukoil, Transneft and Gazprom. Many readers will be familiar with Russia's 


\section{$\mathrm{X}$}

Preface and acknowledgements

oil and gas companies, as the petroleum industries have been the topic of much scholarly and media attention. The progression from less to more familiar ground is intended to draw attention to the general characteristics of statecompany relations in the energy industries. Institutional development and its impact on foreign policy is a broader phenomenon connected to the political economy. Readers interested in the use of gas relations as a foreign policy tool, or in natural monopolies, will find it useful to read the chapters on electricity and nuclear energy, and vice versa. The analysis of Transneft is particularly revealing when it comes to natural monopolies. The chapter on Lukoil provides insight on the differences between state and private companies, but the impact of these differences on foreign policy and on company development come to life in the Gazprom and RAO UES/Inter RAO chapters.

In the Conclusion, I sum up the importance of mutual advantage for the state and business in the development of foreign operations and foreign policy. Towards the end of the period under study, four of the five companies became tools of national economic interest. This held some advantage for the companies. In the latter years discussed here, Russia's foreign economic policy in the post-Soviet region reached certain limits. I propose that this marks the end of the post-Soviet period. I also argue that resource abundance led to slowed development, pinning this down to the combined effects of institutional informality and privilege and the vested interests generated by vast resources. Last but not least, the Conclusion points out that limited access orders have fewer institutional obstacles to the use of companies as foreign policy tools. Particularly when property rights are weakened, states like Russia may have access to foreign economic tools that there are more barriers against using in other political systems. For state-owned companies, the book presents evidence that considerations of company development and efficiency may act as barriers against becoming tools of the state, at home and abroad.

This book is based on a variety of sources, including news media, trade journals and industry reports, both international and Russian. Company websites and reports provide much information and have been used throughout. This wealth of information is unevenly distributed across the cases. Gazprom is by far best covered in existing research, and it has the most comprehensive company website. Lukoil is also quite well covered, both in the Russian media and in international trade journals and financial media. Rosatom and the nuclear energy industry's development in the 1990s and 2000s were for long far less discussed. This improved in the 2010s, but the smaller size and fewer competitors of the global nuclear energy industry contribute to less abundant international media coverage, and fewer trade journals. Analysis of the Russian electricity industry was detailed during the reform period (1998-2008), but relatively little remains from before 1998. After 2008, much company information from RAO UES was available on a preserved website until 2018. The electricity industry in Russia is still rather well covered by Russian media, but Inter RAO is now a less open and transparent company than in 2008. Transneft is overall the least researched and 
least accessible company. A dearth of sources was somewhat remedied by Russian oil and gas trade journals. For all cases, the quality and quantity of Russian news media and trade journal sources are best between the late 1990s and the early 2010s, and distinctly poorer after 2014 .

The written sources were complemented by two rounds of interviews in Moscow in February 2009 and September 2012, with follow-up contact in November 2017 and April 2018. All in all, 23 interviews with 20 people, evenly split between company/industry representatives on the one hand, and scholars and analysts on the other. Interviews were semi-structured, and lasted from one to two hours. One follow-up interview was conducted by phone. The industry representatives came from every industry discussed in the book.

Writing this book would not have been possible without the generosity and patience of many people. I extend a heartfelt thanks to all my interviewees in Russia for taking time away from busy work schedules to share your insights and long experience with me. Your generosity and curiosity in the project brought a wealth of perspectives into the process, for which I am very grateful.

The book is the result of research that began in Vladimir Putin's second period, and was completed early in his fourth period. I thank my employer, the Norwegian Institute of Defence Studies (IFS) at the Norwegian Defence University College, for the possibility to undertake the project and see it through to this book. IFS colleagues deserve a special thanks for their interest and support; none more than Professor Kåre Dahl Martinsen. Your comments on the book manuscript were always critical, generous and often humorous, and our discussions were really enjoyable. I also thank colleagues in the Russian Security and Defence Programme for our interesting discussions, and in particular, Håvard Bækken, Jardar Østbø and Katarzyna Zysk for criticism and comments on parts of the book.

The map in Chapter 6 is reproduced with the kind permission of Transneft. Anna Therese Klingstedt prepared it for this book; your help was greatly appreciated. And in Chapter 7, there would have been no map without your expertise. I am deeply thankful to you for the time and effort that went into our collaboration, and to the Norwegian Defence University College for providing us with the necessary time and not least software. I am also grateful to Research Professor Arild Moe of the Fridtjof Nansen Institute for helpful advice on maps in particular.

The Norwegian Defence University College library has supported the work throughout, its librarians always seeking even better ways to help. Nina Eskild Riege and Einar Tokvam Jamne were Head Librarian and Special Librarian during particularly challenging periods. It is a pleasure to acknowledge your help.

The project came to life as a $\mathrm{PhD}$ thesis at the University of Birmingham, where the Centre for Russian, European and Eurasian Studies (CREES), now housed at the Department for Politics and International Studies, was my 
intellectual home and a stimulating research environment. Thanks to everyone at CREES and in particular my two supervisors, Julian Cooper and Richard Connolly. You never wavered in your enthusiasm and support, and indispensable advice, for which I will always be grateful.

In 2017-2018, I was fortunate to have the possibility of visiting the Institute for Industrial and Market Studies at the Higher School of Economics National Research University, through the International Center for the Study of Institutions and Development and its visiting research programme, twice during the academic year. Thank you to everyone, and especially to Professor Andrei Yakovlev for your generous welcome and to Olga Masyutina for great administrative support.

The transition from thesis to book, and then progress of the book project, was made much easier by the steady hand and helpful advice of Peter Sowden, my editor at Routledge. Your work was highly appreciated. The last leg of the process took place in the unusual spring of 2020. I could not have had a better guide to the copyediting process than Kristina Wischenkamper. Thanks to your efficient work and kind emails, exceptional times turned into good working days.

Many others have been generous with their time, comments, support and discussion of the project at different points in the process, including Pami Aalto, Margarita Balmaceda, Tatyana Dolgopyatova, Jakub Godzimirski, Jonas Grätz, Caroline Kuzemko, Boris Kuznetsov, Julia P. Loe, Arild Moe, Indra Øverland, Alexandra Prodromidou, Elena Shadrina, Hanna Smith, Aglaya Snetkov, and Veli-Pekka Tynkkynen. I also thank the anonymous reviewer, whose detailed suggestions and advice were really welcome.

With so many people to be grateful to, the book remains subject to the usual disclaimers. For the final result, including all the book's inevitable errors and omissions, I take full responsibility.

Without the support from my family and friends, this book would not have happened. Thank you Inger and Nils for much support over many years, and especially for spending so much time with your grandchildren, to everyone's enjoyment. And Magnar, Knut and Synneva for endless love and joyful distraction, and more encouragement than anyone could reasonably expect when the book often took time away from you. I'm sorry that it still doesn't fit the requirements for the school reading competition. You are the best.

\section{Note}

1 According to some reports, the police used a circular saw. Most reports claim that the door was opened forcefully with a power tool, and they form the basis of my account here. However, at least one report claims that such force was not used. 


\section{Note on translation and transliteration}

All translations from Russian language sources that appear in the text are my own. Names in Russian, Ukrainian and Belarusian are transliterated according to simplified versions of the Library of Congress's romanisation tables, using ya/yu instead of ia/iu. All soft and hard signs (for Ukrainian and Belarusian, diacritic signs (i, $\breve{i})$ ) have been omitted in the text, but retained in the references. There are a few exceptions to the general system of transliteration. Well-known names such as Yeltsin (not Eltsin), are spelled according to English language conventions. The same applies to geographical names, like Moscow, and company names where companies have established English-language versions. For references to English language publications, authors' names are displayed as in the English original.

For sources and names in other languages, the spelling of names conforms as closely as possible to the prevalent forms in the country in question at the time of writing, except where conventions apply in English. Where two alphabets are in use, such as in Uzbekistan, a simplified version of the language's Latin script is used. 


\section{Abbreviations and acronyms}

$\begin{array}{ll}\text { ACG } & \text { Azeri-Chirag-Gunesli (oil field) } \\ \text { AIOC } & \text { Azerbaijan International Operating Company } \\ \text { ARMZ } & \begin{array}{l}\text { Atomredmetzoloto (company name until 2008) (nuclear } \\ \text { energy industry) }\end{array} \\ \text { ASE } & \begin{array}{l}\text { Atomstroieksport (name of parts of reorganised company } \\ \text { before 2016) (nuclear energy industry) }\end{array} \\ \text { bcm } & \text { billion cubic metres (of gas) } \\ \text { BPS } & \text { Baltic Pipeline System (oil), in Russian: Baltiiskaya } \\ & \text { truboprovodnaya sistema-BTS } \\ \text { BTC } & \text { Baku-Tbilisi-Ceyhan (oil) pipeline } \\ \text { BTE } & \text { Baku-Tbilisi-Erzurum (gas) pipeline } \\ \text { CAATSA } & \text { Countering America's Adversaries through Sanctions Act } \\ \text { CEO } & \text { chief executive officer } \\ \text { CIR } & \text { Caspian Investment Resources } \\ \text { CIS } & \text { Commonwealth of Independent States } \\ \text { CNPC } & \text { China National Petroleum Corporation } \\ \text { CPC } & \text { Caspian Pipeline Consortium (oil), in Russian: Kaspiiskii } \\ \text { truboprovodnyi konsortsium-KTK } \\ \text { CSR } & \text { Corporate social responsibility } \\ \text { EBRD } & \text { European Bank for Reconstruction and Development } \\ \text { EEU } & \text { Eurasian Economic Union, in Russian: Evraziiskii eko- } \\ & \text { nomicheskii soyuz-EAES } \\ \text { ESPO } & \text { East Siberia-Pacific Ocean (oil) pipeline, in Russian: } \\ & \text { (nefteprovod) Vostochnaya Sibir'-Tikhii Okean-VSTO } \\ \text { EU } & \text { European Union } \\ \text { FAS } & \text { Federal'naya antimonopol'naya sluzhba, in English: Fed- } \\ & \text { eral Anti-Monopoly Service } \\ \text { FSK } & \text { Federal'naya setevaya kompaniya, in English: Federal } \\ \text { FST } & \text { Grid Company (electricity) } \\ \text { G8 } & \text { Federal'naya sluzhba po tarifam, in English: Federal } \\ \text { HEU } & \text { Tariff Service } \\ & \text { Group of Eight } \\ \text { highly enriched uranium }\end{array}$


HPP

IAEA

IFRS

IOC

IPO

IUEC

JV

KGB

KPO

LEU

LNG

$\mathrm{mcm}$

MFA

Minatom

Minsredmash

NATO

NDPI

NMMC

NOC

NPP

NPT

OVR

PSA

RAO UES

Rosimushchestvo

RSBU

RSPP

SNF

SOCAR

SVOP hydropower plant

International Atomic Energy Agency

International Financial Reporting Standards

international oil company

initial public offering

International Uranium Enrichment Centre, in Russian:

Mezhdunarodnyi tsentr po obogashcheniyu urana-MTsOU joint venture

Komitet po gosudarstvennoi bezopasnosti, in English:

Committee for state security (obsolete)

Karachaganak Petroleum Operating Consortium

low-enriched uranium

liquefied natural gas

thousand cubic metres (of gas)

Ministry of Foreign Affairs, in Russian: Ministerstvo

inostrannykh del-MID

Ministerstvo po atomnoi energii, in English: Ministry for atomic energy

Ministerstvo srednego mashinostroeniya, in English:

Ministry for Medium Machine-Building

North Atlantic Treaty Organization

nalog na dobychu poleznykh iskopaemykh, in English:

consolidated production tax

Navoi Mining and Metallurgy Combinat

national oil company

nuclear power plant

Treaty on the Non-Proliferation of Nuclear Weapons

Otechestvo - Vsya Rossiya, in English: Fatherland - All

Russia (political party)

production sharing agreement

Rossiiskoe aktsionernoe obshchestvo "Edinaya Energe-

ticheskaya Sistema", in English: Russian shareholding company United Energy System (literally: single energy system)

Federal'noe agenstvo po upravleniyu gosudarstvennym

imushchestvom, in English: Federal Agency for State Property Management

Rossiiskie standarty bukhgalterskogo ucheta, in English:

Russian Financial Reporting Standards

Rossiiskii soyuz promyshlennikov i predprinimatelei, in

English: Russian Union of Industrialists and

Entrepreneurs, RUIE

spent nuclear fuel

State Oil Company of Azerbaijan

Sovet po vneshnei i oboronnoi politike, in English: Council for Foreign and Defence Policy 
xvi Abbreviations and acronyms

tpa

tonnes per annum (oil)

TPP thermal power plant

UES united energy system (electricity), in Russian: edinaya energeticheskaya sistema-EES

UGSS united gas supply system, in Russian: edinaya sistema gazosnabzheniya - ESG

VVER vodo-vodyanoi energeticheskii reaktor, in English: pressurised water reactor (nuclear energy industry)

WTO World Trade Organization 


\section{Introduction}

\section{Energy and the institutional development of the Russian state}

Russia's international position today is built on energy. Energy resources, especially international oil and gas supplies, make up the fundaments for Russia's position as a great power in international relations and provide revenue for power projection, military and otherwise. Russia's return to great power politics during Vladimir Putin's presidency initially surprised the West, which had in the 1990s become accustomed to a more compliant Russia with little capacity to spare for global affairs. For the post-Soviet states, however, Russia never really went away. While much weakened, it remained a great power in the region, especially in economic terms. Energy power was a central pillar of its position, and underpinned its return to global power status after 2000. Russian energy power has therefore played multiple roles in Russian foreign policy since the end of the Soviet Union. In the 2000s, Russian policymakers came to see it as a source of global and regional power. By virtue of Russia's role in global energy supply, energy relations became a backbone of foreign policy towards a wide variety of states, from Germany to Iraq and China. Due to the legacies of the Soviet economy, energy relations in the post-Soviet region were also potential tools of influence on other states. This turned Russian energy companies into a staple of Russian foreign policy in the post-Soviet region.

At home, Russian energy companies were central to the ability of the state to formulate policy, implement, compel and coerce. Just as Russia in 1992 found itself far feebler in relation to the then newly independent states (quickly conceptualised as the "near abroad"), the state was also considerably weakened with regard to its most basic tasks, including the extraction and redistribution of resources. But the weak Russian state of the 1990s managed to keep afloat, relying to a considerable extent on large companies. Gazprom stepped in when there was a hole in the state budget. The power holding United Energy System (hereafter RAO UES) supplied electricity without payment across regions and industries. Oil companies produced as much oil as they could possibly sell, and paid some taxes. Oil and gas pipelines brought crude oil and natural gas to international markets, even when there were no funds for repairs. The gigantic nuclear energy industry did not disintegrate and turn into a source of illicit nuclear materials, but kept it going, somehow. 


\section{Introduction}

In this way, the large companies that had been formed from production units and ministries in 1991 were indispensable to the state at home. This relationship influenced Russia's political development for years to come. It placed the companies in positions where they could influence foreign policy and act as foreign policy tools in the post-Soviet region. The development of Russia's political economy mattered for its foreign policy.

To analyse how state-company relations influenced foreign policy, the book applies a theoretical framework that builds on social order development, drawing heavily on new institutional economics (North et al., 2009). Development, both political and economic, is understood as institutional development. Companies' role in institutional development made it possible for them to influence foreign policy formation, and domestic institutions made them available as tools to implement foreign policy. The combined power of several industries was a key feature of Russian foreign policy, both in bilateral relationships and as a support for Russia's regional position.

That institutions matter, also when they are in flux, is a recurrent topic in studies of Russian foreign policy. Institutional weakness and resourceful actors characterised Russian foreign policy formation in the 1990s (Malcolm, 1996; Sharlet, 2001, p.199). It remained a feature into the 2000s, impacting relations with Europe, the post-Soviet region and the Middle East (Wenger et al., 2006; Torbakov, 2013; Gvosdev and Marsh, 2014; Marten, 2015) as well as the accession process to the World Trade Organization (Guriev and Rachinsky, 2005, p.146; Connolly and Hanson, 2012, p.489). In the comparative literature on post-Communist transitions, institutional development provides an important explanation for states' integration into the global economy (Guriev and Rachinsky, 2005; Brada, 2013; Drabek and Benacek, 2013). In analyses of Russian foreign policy formation, the salient institutional feature has been a weakly developed institutional framework, supplemented by extensive informal relations between state actors and businesses (Bukkvoll, 2003; Aalto et al., 2012; Balmaceda, 2012; Kivinen, 2012; Poussenkova, 2012; Marten, 2015). Business interests, also in the energy industries, have exerted significant informal influence on foreign policy. The background is found in Russia's political economy, which has been profoundly shaped both by resource abundance, and by energy companies as actors (cf. Fish, 2005; Sutela, 2012; Cooper, 2013; Malle, 2013; Mau, 2016; 2017; Miller, 2018). How business influence on foreign policy has changed over time is however less studied.

One common premise of the institutional explanation for Russian foreign policy is that informal institutions subvert formal institutions, thereby contributing to state weakness. This explanation originated in a scholarly debate over whether business or state actors were more powerful amid weak institutions (for the former view, see Hellman, J., 1998, and Hellman, J.S. et al., 2000, for the latter view, see e.g. Yakovlev, 2006, and Sakwa, 2008). A related discussion centred on whether state-business relations were less conflictual, with wider elite integration amid a fluid, informal 
institutional environment (Åslund, 1999; Peregudov et al., 1999, p.290; Rutland, 2001; Frye, 2002; Ledeneva, 2006; 2013). Building on the studies of elite integration, recent works have analysed how networks of economic and political patronage weaken both state and society (e.g. in Easter, G.M., 2012, pp.20-21; Gel'man, 2015; Hale, 2015, p.10). But even when the state is weak, weakness and informality are only part of the overall framework for state-business interaction. It is the combination of formal rules of the game and their informal interpretation in elite networks that shapes Russia's development.

Integration among political and business elites has important implications when discussing state-company relations over foreign policy (cf. Balmaceda, 2012, p.153; Kaczmarski, 2014). For example, in the case of Gazprom, the political use of energy in foreign policy is frequently seen as external to (Stern, 2005, pp.102-104; Pirani, 2009, pp.5-8) or in subversion of companies' genuine, business-related goals (Baev, 2013; Busygina and Filippov, 2013; Closson, 2014). However, when understood in terms of personalised interaction and mutual support, or mutual favours, it can make considerable sense for a company to make itself useful to the state, also from a business perspective. Margarita Balmaceda (Balmaceda, 2012; 2013) has proposed that Gazprom and other companies accumulate "convertible points" with the Russian state in both the foreign and domestic realm. These "points" can later be translated ("converted") into advantages for the company (Balmaceda, 2012, p.143). The advantages may be significant outside the domestic political economy too. Boris Barkanov finds that Gazprom became a vehicle of Russian statecraft in relations with Europe, but this co-optation enabled Gazprom to influence the terms of Russia's integration into international markets (Barkanov, 2018). Likewise, Adam Stulberg shows how Gazprom and the Russian state coordinated their positions when adjusting to changing constraints in the European gas market in 2013-2015, resulting in a compromise that preserved Ukraine as a gas market for Gazprom (Stulberg, 2015). Gazprom influenced its business environment to a greater degree than what could have been achieved without state support.

The relations suggested in these studies are far from a situation where energy companies see their international business strategies subverted by the state. A more complex understanding of state-business relations over foreign policy is inevitably more complete, particularly when analysing it from the point of view of how these relations connect to those of the domestic political economy. To conduct such an analysis, it is necessary to study state-business relations over time, and include companies in other industries than gas. Adding to the relatively few studies to date that look at several companies over more than a few years (Wenger et al., 2006; Stulberg, 2007; Meister, 2013), this book shows how five energy actors, RAO UES/Inter RAO, Minatom/Rosatom, Lukoil, Transneft and Gazprom, interact with the state and shape Russia's political economy. The findings are then used to show how political economy development influences foreign policy. 


\section{Introduction}

\section{The development of the state and state-company relations}

The reality of the Russian state in the early 1990s was far from the stable, predictable and transparent implementation of an ideal state in the Weberian sense. The Soviet economy by 1990 had a "systemic vacuum" at its heart: "The old planning system has broken down but has not been dismantled; meanwhile, the structures vital to the functioning of a market have yet to be put in place" (IMF et al., 1990, p.1). The systemic vacuum left the state only a nominal force in segments of the economy at the break-up of the Soviet Union at the end of 1991. The reforms introduced by the new Russian government in early 1992 were meant to create private ownership in a market economy. However, as old Soviet institutions were still not dismantled, two sets of institutions existed side by side in two overlapping but incomplete systems until the new Constitution was put in place in late 1993. The chaos of reforms in 1992-1993 further weakened the capacity of the state to regulate the economy, which was in the midst of a transformational recession (Popov, 2013, p.102). The rules of the game were contradictory and in flux, with only a weak rule of law. Private interests and informal networks were prominent in political decision making. When faced with impending financial crisis in 1998, elite disunity and government policies exacerbated Russia's problems. The result was debt default. Ten years later, government policies, once established in 2009, quite successfully met the next international financial crisis. But this response did not use the crisis to embark on structural reform, facilitate new growth, and ease dependence on hydrocarbon production. Instead, it contained sources of stagnation. A few years later, there was a tendency towards state-led development and isolationism in Russia's reaction to the oil crisis in 2014-2016. These four crises, 1991-1993, 1998, 2009-2010 and 2015-2017 (the years of Russia's own economic crises) are milestones in the development of the Russian state.

The trajectory of post-Soviet Russia illustrates how the institutional framework of the state is essential to a functioning modern economy, and that change in the state goes hand in hand with economic change. The Russian state went through a transformation from a fragile state, with little capacity to uphold stable institutions and predictable practices, to an increasingly cohesive organisation with more clearly delineated institutions and interests. The moribund late-Soviet state, incapable of responding forcefully to, let alone shaping, developments in the economy, degraded further into a transitional chaos. Gradually but slowly, the post-Soviet Russian state became more active and flexible, responding with differentiated institutional frameworks for different sectors. Energy companies were integral to this development. They emerged out of state structures in the early 1990s, and by the 2000s they were distinguishable as companies. They had changed from Soviet enterprises wielding control only over the processes of production, to vertically integrated companies with command over input, production, marketing and profits. In return for state and regime support, they shared 
their rents, which included more than just profits, with the state and wider Russian society, through taxation and other channels. This increased the resources available to the state, and ipso facto state capacity.

Change in the state, and specifically, the state's ability to formulate policy and implement it, also pertains to foreign policy. Foreign policy is a specific policy area, often somewhat removed from everyday domestic politics, but it is still affected by the state's capacity to formulate coherent policies and implement them effectively. In the 1990s, many choices of Russia's economic and political transition were linked to foreign policy, and specifically to relations with other post-Soviet states. This applied to choices concerning the organisation of multilateral relations among the post-Soviet states, the pursuit of integration into the global economy, and how bilateral affairs with other states could be exploited for Russia's benefit. Many issues remained unresolved until the mid-1990s. The institutional framework, moreover, was unclear and in flux, leaving considerable room for actors to influence events and policy.

In the energy industries, Russia was left in control of an overwhelming share of infrastructure. State attempts to introduce institutional change for these industries had consequences for the post-Soviet region. Energy companies' operations in the region represented, to the Russian state, a powerful tool of foreign policy in a situation when the elites in Moscow found themselves with a markedly reduced toolbox of influence in its immediate neighbourhood.

\section{The institutional legacies of the Soviet planned economy}

The Soviet economy was a single structure, giant but centralised. Soviet enterprises were not firms in the Western sense, but production units in USSR Inc. (Hanson, 2003, pp.9-13). Institutional transformation was a slow and uneven process. Economic transition, which aimed to change the Soviet economic system into its opposite, was an immense task. In practice, Soviet institutions were in many cases carried over into each post-Soviet state, leading to further degradation (Ericson, 2013, pp.60-61). These institutional remnants continued to function in new circumstances and made it possible to rely on Soviet-type rules and procedures also after 1991. Institutional legacies are here seen to have passed from the Soviet Union to post-Soviet Russia, sometimes in modified form, to become the basis for further institutional and organisational development. This view, that legacies are modified and changed by institutional continuity, sets the definition used here apart from other contributions that define legacies as durable relationships over a longer period of time (Huskey, 2014, p.111; Kotkin and Beissinger, 2014, p.12).

The legacies of USSR Inc. matter in three ways. The first is systemic and concerns the overall structure of the economy. The Soviet economy was characterised by a lack of distinction between economic organisations, at the same level and within and between different hierarchies. Gradually, from the 


\section{Introduction}

late Soviet years (1987-1990) to the mid-1990s, organisations from the giant Soviet superstructure became tangibly distinct units within a Russian economy undergoing reform. Other parts of the superstructure were torn away in the break-up and became the property of other post-Soviet states. The speed of change was shockingly rapid in terms of economic history and in everyday life. Nevertheless, the process of mutual adaptation was a gradual one. The boundaries between the state and company levels remained somewhat indistinct during the 1990s. Where state organisations were targeted for insider privatisation, as happened in the power industry (with RAO EEK), nuclear energy industry (with TVEL Concern) and in Transneft, the resulting entities were ambiguously affiliated with the state. Also at times in the 2000s, the dividing line between core state organisations, state companies, and partially state-owned companies remained blurred and their responsibilities diffuse in some industries. Even so, there was a centrifugal movement away from the state as an economic superstructure, and towards institutionalisation of eventually more distant, and more clearly delineated, ties between the state and the companies. Likewise, the basic institutions that structured the economy, relations of property and organisational autonomy, continued to bear a Soviet imprint that only gradually changed.

The second legacy of USSR, Inc. was the institutional framework at the industry level. Gazprom, RAO UES, Transneft and Rosatom survived relatively intact and unreformed until the mid-1990s, and even the outlier in this regard, Lukoil, started as a legacy company in the privatised Russian oil industry. The four others survived because they were infrastructural monopolies in their respective sectors. In 1992, the Russian state embarked on a transformation that would eventually turn the economy into a partial market economy. However, the institutions that regulated these companies changed at a more leisurely pace. The organisations took on traits that turned them more (Gazprom) or less (Transneft) into companies, but their relations with the state were based on their status as monopolies and on informal rent sharing. The energy sector's institutional framework remained a legacy of the late Soviet period for at least a decade, with gradually introduced modifications. The companies were therefore capable of influencing state policies to an extent not seen in many other sectors, with the defence industry as a possible exception.

The institutions that structured ties with the other post-Soviet states was the third legacy. USSR Inc. extended throughout the entire Union, and linked enterprises by sector across internal boundaries (Bradshaw, 2008, p.194). Over the 25 years that followed the break-up of the Soviet Union, the post-Soviet states have moved away from what was once the centre of USSR Inc. PostSoviet states today are now distinctly different to an extent that was difficult to foresee in 1992. This pertains even as subgroups among the post-Soviet states continue to display political and economic similarities. There is an infrastructural side to this legacy. The pipelines and power grids criss-crossing internal borders were a physical, infrastructural expression of the Soviet 
Union. As Soviet transport grids were concentrated on Russian territory, Russian energy companies were left with more of the Soviet production and transportation chains under their own control than other companies. The companies studied here were large and forceful entities in the post-Soviet context. Due to widespread Soviet rent addiction (Gaddy and Ickes, 2010, p.293), discussed on pp.8-9 and 263, there was a demand for Russia's presence in the energy sectors of other states.

\section{State-company relations and institutional change}

The legacies of the Soviet economy were from the beginning used, and shaped, by Russian elites in a general struggle for power and resources. State-company relations did not progress as a neat negotiation process between two clearly delineated sides. State fragmentation and incapacity in the 1990s opened opportunities for elites, regardless of nominal affiliations with the state or a company, to influence policy and shape property relations. Control of the state's mechanisms for control and coercion was the ultimate weapon against any rival group. Weak state organisations would be employed as fronts for business interests, whereas the stronger would compete with each other for influence. State bodies and new private organisations informally related to state organisations, were available for hire and protection. As the saying went, "the red roof is the tallest and most influential" (Veligzhanina, 2000).

Change in the state, the economy and state-company relations is analysed building on the conceptual framework of social order, introduced by Douglass North, John Wallis and Barry Weingast (North et al., 2009). State-company relations generally reflect the capacity of the state to uphold companies (North et al., 2009, p.47). Companies rely on the state for their very existence, and the state relies on companies to create economic resources for it to extract and redistribute. State regulation of the economy includes overall support for the existence of companies, fundamentally the basic institutions of property rights and contract enforcement, and the institutions that extract resources, such as taxation, and redistribute them through different channels for spending. Institutions are here defined as the rules of the game devised by humans but constraining human interaction (North, 1990, p.4), while state organisations and economic organisations like companies are here all seen to be the players in the game (North, 1990, pp.4-5).

Like many other states, Russia is a limited access order (Connolly, 2013), where access to valuable resources and activities, such as the formation of significant political and economic organisations, is a restricted privilege (North et al., 2009, p.21). In turn, the privileged form a ruling coalition and control the state. The alternative is an all-out war for control of the state. There is no division between economic and political power. Instead, the distribution of political and economic power must correspond for the social order to be stable. Limited access orders are different from open access 


\section{Introduction}

orders, where the access to start or acquire a company, or stand for political office, is an impersonally enforced right and political and economic power are strictly delineated (North et al., 2009, pp.11-12). In limited access orders, institutions constrain differently, as rules are enforced according to privilege, not rights. Relations between the Russian state and large companies have been shaped by a social order that maintains privileges, from the dependence of big companies on particularistic treatment from the state for business development (Hanson and Teague, 2005, p.674), to state actors' privilege to take control of companies (Gans-Morse, 2012; Hanson, 2014; Rochlitz, 2014), to the persistent difficulties of Russian business in using collective action to resist predation and violence from the state (Yakovlev et al., 2014). Without impersonal protection of property rights, reasonable and transparent taxation and open access to markets, companies need to pursue close relations with the state in order to operate and survive. In practise, top managers need to interact with the state's top politicians. In return for the privilege of property right protection and access to economic resources, managers and owners often willingly accept obligations to serve the state. They share their rents with members of the ruling coalition, here called the regime. Rent sharing plays a significant role in increasing state capacity. In result, the regime is relatively stable and in a position to rule.

\section{Resource abundance and institutional development}

Close and personal elite relations place resource-rich energy companies in a powerful position towards the state. Comparative political science has long discussed the challenge that resource abundance, and more specifically, oil wealth, poses for political development (Karl, 1997; Ross, 1999; 2001; Jensen and Wantchekon, 2004; Ross, 2012). This effect has been pinned down more narrowly as one of oil wealth on institutions (Luong and Weinthal, 2006; 2010; Weber, 2018). What matters for regime survival or collapse is the level of institutional development at the moment when resources increase (Smith, 2007). However, the concern here is not collapse, but institutional change in relation to the very industries that control abundant resources. It is reasonable to expect that the wider economic and political effects of wealth, especially increasing wealth, matter. Increased rent streams affect the potential gains of privilege, and may create vested interests that resist change, or have an interest in specific changes.

This is well known from Russia, where there are powerful vested interests favouring the status quo (Yakovlev, 2006; Rochlitz, 2015; Mau, 2016; 2017). There are simply too many groups in the elite with too much to lose from change. Clifford Gaddy and Barry Ickes argue that one economic legacy of the Soviet system is a societal addiction to energy rents. Rents from energy export were in the Soviet period turned into cheap and abundant energy and used to alleviate the effects of, and expand production in, inefficient sectors of the economy (Gaddy and Ickes, 2010, p.293). As a consequence, Russia's 
economic structure was altered, and the interruption of rents will incur potentially disruptive shocks to the system (Gaddy and Ickes, 2013). The elites are aware of this, as illustrated by their priority of keeping factories open during the 2009-2010 crisis, and of accessing more rents from the resource industries after 2014. Rent addiction furthermore extended across the former Soviet Union, with the abundant flow of cheap energy mostly directed from Russia to the other republics. This inherited energy dependence on Russia created rent claimants across the post-Soviet region.

\section{Institutional development: formality and informality}

Returning to the question of how resource abundance affects institutions, Pauline Jones Luong and Erika Weinthal (2010) argue that considerations of power maximisation among leaders result in different types of petroleum ownership. Ownership arrangements in turn shape institutions. Indirect resource management and private ownership speed the development of institutions and state capacity, as in the case of the Russian oil sector before 2005. Direct management through state ownership, as in the case of Gazprom, lets the state access rents directly, but its capacity does not develop as much and the state by necessity acquires a greater role in managing the economy (Luong and Weinthal, 2010, pp.121-180).

However, institutional change cannot be studied without taking into account how ownership is exercised. Resource management institutions may change independent of ownership changes like nationalisation or privatisation. For example, specialisation in the shape of market making strengthened the state and built state capacity in the Russian electricity sector (Wengle, 2012; 2014). Privatisation was only one part of this process, and the institutional framework established during the electricity reform exists regardless of ownership structure. On the other hand, formal rules are not applied impersonally in Russia, neither in law enforcement (Paneyakh, 2014) nor in relation to major companies (Sharlet, 2001; Hanson and Teague, 2005; Sakwa, 2008; Kluge, 2017). The informal rules of the game complement, but also undermine, formal institutions, to the point where informality is seen to represent the "normal" in society from the point of view of e.g. owners of smaller businesses (Vasileva, 2018). At the very top of the elite, informality places opaque constraints on political leaders (Monaghan, 2012, p.8). This impedes the emergence of impartiality, the constant codification, modification and specialisation in institutions that are essential to institutional development.

To capture overall institutional development, institutional variation is approached as a continuum from perfect formality, where rules and rights are applied uniformly and perfectly impersonally, to complete informality, where there are no rules and no property rights, apart from those established through privilege and personal connections. While neither extreme exists in the real life of modern states, the balance between informality and formality indicates a level of overall institutional development, both with regard to a specific industry, and at the aggregate level, in the social order. 


\section{Introduction}

\section{Oversight and control: access and participation}

Returning to the institutional framework, ownership and markets are analytically distinct from the extent to which the state can implement rules and exercise oversight. Informality and its opaque constraints weaken the state's capacity for policymaking and industry control. Instead, policymaking and oversight are likely to be undercut, but also underpinned, by informal relations between state representatives and representatives of the companies. Regulation and policymaking for major companies and their industries turn into a matter of discretion for high-level state actors (Easter, G.M., 2012, p.169), showing how big economic organisations in a limited access order are "necessarily also political ones" (North et al., 2009, pp.268-269). A lack of differentiation between state and private interests also occurred in companies nominally controlled and owned by the state. Formal ownership diverged from de facto, informal control.

This dimension of the institutional framework is often referred to as informality, but the complex reality of weakly enforced institutions and informal privilege demands a more precise description of inclusion and exclusion among elites and their organisations. To capture it, I apply two simple concepts, access and participation. ${ }^{1}$ Access includes opportunities available to top company managers to approach key Russian state officials and top politicians, the regime, and the possibilities available to the state to exercise oversight and extract resources from the companies. The extent of state access reflects its capacity to support more complex economic organisations with less direct ties to the government. The companies' responses reflect their adaptation to the changing state. On occasion, company managements used relations with the state to initiate change. Often company managements resisted the state.

Participation is the extent to which companies influenced government policymaking, and the state could influence sector development. Could the companies influence their institutional environment? From the state's point of view, it is participation in company development and an opportunity to influence company strategies, including foreign operations. In this way, access and participation in formal and informal channels of interaction complemented the formal and informal rent streams described below. In the analysis, these concepts are used to gauge how state capacity to support economic activity, extract and redistribute resources developed over the period under study.

\section{Formal and informal rents}

Finally, resource extraction and redistribution are central to the relationship between the state and companies. Gaddy and Ickes argue that Russia's rent management system is an institutional framework for state-business ties (Gaddy and Ickes, 2010, p.292). They define oil and gas rents in Russia as the 
surplus obtained from oil and gas production (Gaddy and Ickes, 2005, pp.560-561). Often defined as "excess payment above that required to induce supply" (Pomfret, 2013, p.415), rent is a common feature and economic challenge of resource-rich economies.

The importance of petroleum rents to the Russian economy increased over the post-Soviet period. In 1992, crude and refined petroleum and petroleum products represented 45 per cent of all Russian exports, which totalled 34 billion US\$ (UN Comtrade database harmonised by Gaulier and Zignago, 2010, accessed through Simoes and Hidalgo, 2011). ${ }^{2}$ While this share fluctuated through the 1990s, it was back at 45 per cent in 2000, with the total at 102 billion US\$. Overall export increased through the 2000s and peaked at 418 billion US\$ in 2008, of which petroleum and petroleum products represented 58.3 per cent. In 2015, Russia's exports totalled 222 billion US\$, and the share of petroleum and petroleum products was 42.5 per cent (UN Comtrade database harmonised by Gaulier and Zignago, 2010, accessed through Simoes and Hidalgo, 2011). ${ }^{3}$ The changes in the value of petroleum export in this period reflect not only fluctuations in the oil price, such as the period of high oil prices from 2003 to 2015, but also the decline of Russia's non-oil producing industries in the period under study.

Informal rent sharing is of particular relevance here, because it gives political leaders more discretion to redistribute rents according to their preferences outside the formal channels of taxation and state budget. In turn, this requires the deliberate weakening of property rights (Gaddy and Ickes, 2005, p.571). Accordingly, the rent management system includes an informal complement to the state's formal relationship with companies. The particular structure of rents is significant. Nominal costs to Russian companies are inflated by excess extraction costs and informal taxes like bribes, while revenues are deflated by price subsidies (Gaddy and Ickes, 2005, p.561). Rent accordingly comes in many forms: excess costs, informal tax, price subsidies, formal tax, and formal profit. Excess extraction costs are claimed by producers, subcontractors and suppliers, but also by employees on inflated staff rosters. Insofar as staff numbers are inflated by the dispensation of (mandatory) favours to privileged recipients, this is related to bribes and other types of informal taxation. General price subsidies relieve consumers and industrial sectors of part of their energy spending in the short term, while stabilising both society and the regime. In terms of the state budget, these are quasi-fiscal arrangements (Luong and Weinthal, 2010, pp.39-40). Quasi-fiscal arrangements have persisted in Russia, even as typical price subsidies of e.g. gas prices to consumers were reduced in the late 2000 s and 2010s (IMF, 2014, p.63). There is little transparency on the extent and especially the cost of such arrangements (IMF, 2014, p.63).

Informal taxes are often couched in the language of voluntary contributions, but from the companies' point of view, they are no less mandatory than formal taxes, because they are essential for property rights protection and company survival. This may also apply to bribes, inflated corporate 


\section{Introduction}

spending on social services and healthcare, politically recommended corporate social responsibility (CSR) spending (Guriev and Tsyvinskii, 2011), culture, sports (Müller, 2015; Rutland, 2015, p.74) and philanthropy. Charity contributions in particular are understood to channel rents towards a wide variety of causes, which may include the development of residences and sports complexes used also for private leisure. Again, little is known on the cost of non-commercial services extended by many companies. A very incomplete estimate for 2012 arrived at a cost corresponding to 0.1 per cent of GDP (IMF, 2014, p.64). CSR programmes, generous healthcare provisions and spending on sports in part relieve the state and regional budgets of the burden of public services, or contribute towards achieving developmental goals set by the government. They can be seen as a substitute for welfare provision by the state. In contrast, formal after-tax profits are generally distributed among owners (shareholders), and in the case of state ownership represent a formal rent stream shared between companies and the state as an owner. In this way, formal and informal resource streams, and formal and informal relations of control, bind the state and companies together and secure political stability.

\section{State capacity and institutional development}

The constraints of informality, the formal and informal channels of access and participation, limit state autonomy from society. This is a brake on Russia's economic and societal development. State and business are both weak because informal institutions, informal rent sharing and weakly protected property rights inhibit the development of state capacity and of financially healthy companies. But as an all-out war among elites remains a likely outcome in the case of regime breakdown, both the state and the companies maintain the status quo.

In the 1990s, the combination of a weak state and weak companies led to the enrichment of a part of the elite, often called the "oligarchs", at the expense of everyone else. This also affected the state. The state fragmented into constituent sectors and regions, with energy remaining closely linked to central state organisations. The fruits of enrichment, the rents, were however not all siphoned off to private coffers. Some were distributed through informal rent sharing, even reaching selected sections of the general population (Ledeneva, 2013, p.278). In return, the elites became reliant on political machines (Hale, 2010, pp.35-37) that delivered votes and stabilised the wider population.

In this way, state and society are linked through formal and informal institutions. The state can rely on both formal and informal channels of rent to extract resources from the economy and redistribute them to various claimants in the elite and wider population. The constraints of informal channels like patronage networks are interlinked with and embedded in the formally articulated institutional context of the state. In for example tax 
collection in 1991-1992, the discretionary powers of formerly Soviet tax collectors were undermined by both formal institutional changes and widespread elite bargaining in informal networks (Easter, G., 2006, pp.32-33). Bargaining remained important in tax collection through the 1990s. However, even after the introduction of a far more formalised, transparent and enforceable taxation system in 2001, exemptions are granted and taxrelated coercion distributed in a context where real property rights depend upon informal, personal relations with the regime, and in the regions, with regional elites (Rochlitz, 2014; Yakovlev et al., 2014; Gans-Morse, 2017; Vasileva, 2018).

The state is more than institutional context. States are also defined by their power, or capacity, exercised by state organisations according to an institutional framework. Here, state power is seen to consist of policymaking power and infrastructural power. Policymaking power is the range of actions that state organisations can undertake without routine negotiation with society (Mann, 2012, p.59). Infrastructural power is the institutional capacity of a state to "penetrate its territories and logistically implement decisions" (Mann, 2012, p.59). Infrastructural power has a central place in analyses of postSoviet Russia (e.g. in Colton and Holmes, 2006; Stoner-Weiss, 2006), which is not surprising considering how infrastructural weakness has limited its capacity. Both dimensions of state capacity are related to institutional development. Without institutions that are to some extent stable, at least somewhat regularised and formalised, state actors will find it difficult to develop policy, let alone implement decisions.

The Russian state was lower in both policymaking and infrastructural power in the 1990s than in the Soviet period. The relatively rapid weakening of the Soviet state during the break-up of the Union left the new Russian state so weak that it lost real, as opposed to nominal, control of state companies and enterprises. This led to a downward spiral of state capacity in the early 1990s. Its capacity in the energy industries was further weakened by frequent changes in the Fuel and Energy Ministry (1992-2000) and its successor, the Energy Ministry (2000-2004). From August 1996 to June 2001, the longest period served by any Fuel and Energy minister was 12 months. As the system eroded from within, existing channels of access and participation were disrupted without new ones emerging, and companies became insulated from the state. They may even have developed into a state within the state, operating beyond the reach of an impotent state apparatus.

In the 2000s, both policymaking and infrastructural power increased. When Putin came to power, he subordinated the fragmented public sector and its constituent political machines to himself and his supporting coalition, thereby strengthening the state both with respect to policymaking and infrastructural power. State actors gained access to resources that under Yeltsin were subject to negotiation with company managers or regional governors. Where the state's reach ended, it could compel for example energy companies to fund services and thereby substitute state welfare. Informal channels of 


\section{Introduction}

rent management, access and participation persisted, but they were now as likely to reinforce the formal institutional framework as to undercut it. As a result, the state could penetrate its territory and energy sectors better, and more effectively. Institutional frameworks were upheld and implemented to a greater extent.

Changes in state capacity reflect the development from a fragile state to a basic state and then to a mature state, while remaining a limited access order. A fragile state can uphold only itself, and a basic state can support organisations that it controls (North et al., 2009, p.21). As state capacity increases further, the state can support organisations outside its immediate reach. It can at least temporarily enforce and protect some contracts and property rights, extract resources from companies not just by owning them, but also through the less direct method of taxation, and regulate market access for at least some companies. As it matures even more, the state can protect property rights more completely and permanently, extract taxes more indirectly, transparently and predictably, and open up and regulate more markets (North et al., 2009, pp.11-12). The depth of specialisation among state organisations, private companies and political groups indicates the level of development, but in a limited access order, any division into "state" and "private" organisations remains conditional and non-distinct, even as state organisations and companies become more specialised and delineated (Zudin, 2013, pp.16-17). The state cannot impersonally protect property rights and enforce contracts that involve members of the ruling coalition, because the imperative to protect privileges is more important for social and political stability. Still, during the change from a fragile to a mature order, institutions become more important for relations among elite groups. Intra-elite relations develop from constant and personal interaction to interaction regulated by (increasingly) formal institutions. Institutions are enforced more impersonally, regardless of privilege. Organisations depend less directly on the personal influence of their top managers (Zudin, 2013, p.17). But there are limits to how impersonal institutions can become in a limited access order before the stability of the regime is threatened.

\section{Elites in the limited access order}

State-company relations at this level are by definition elite relations. This is especially true of Russia, where elites form a top layer in public affairs, while the general population has only limited influence on how, and whether, its interests are represented in politics at all (Levada, 2010, p.85). As such, the analysis is concerned with a limited set of relations among a few elite groups. Business elites are expected to be prominent. The book shows how company managers, top state bureaucrats and some parts of the ruling coalition were all important to institutional development for and within these industries. While government priorities, also in national security or foreign policy, mattered for overall national development, industrial policies 
and institutions that regulate the economy in Russia have been shaped, primarily, among elites from those industries, and second, among elites with a more general managerial or political background. This broader elite is crucial for regime stability (Rivera and Rivera, 2006). As discussed throughout, and particularly in Chapter 5 on Lukoil, company managers are often aware of this role and loath to rock the boat of current property right arrangements and privileges, even when that reality does not serve their business all that well.

The people in this book are state and company actors, sometimes both. All the companies' predecessors were production units and ministries in the Soviet economy. Their original top managers were industry specialists first and Soviet managers second, typical of the so-called "Red Directors" who had made their careers as enterprise directors before continuing to climb the hierarchy within only one industry (Fortescue, 2006, p.24). Over time, many of Russia's "Red Directors" were replaced by general managers, younger men with a more diverse managerial background. Among the protagonists in this book, the most typical successor to the "Red Director" is a state bureaucrat or technocratic politician, with or without prior knowledge of the industry in question. These people all had close relations with the government, and often with the president when they were appointed to top company positions. In the case of Minatom/Rosatom, they are government members or heads of agencies, although the relations are more complicated than indicated by formal positions. Among the state actors, ministers and otherwise, we find typical reformers in the 1990s as well as trusted, loyal and experienced technocrats in the 2000s.

While the composition of Russia's elites underwent change, how infighting, not consensus, characterised elite relations did not. From the beginning, the breakdown of the Soviet system, reforms and economic crisis were accompanied by elite fragmentation. Personal connections and the sharing of informal rent streams were integral to elite relations under Yeltsin, also when they concerned policy formation and implementation. Elite networks certainly mattered in state-company relations. In the 1990s, financial and operational control over Gazprom in particular was almost tantamount to control of the state via the state budget. Added to this was the possibility of accessing rent streams through companies. The larger the company, and the greater its potential as a source of rents, the more central an object it became in conflicts over control of the state.

Under Putin, these mechanisms changed, and they became less visible. Following his accession to power, he had sufficient support among elites and population alike for a conditional and temporary agreement to emerge. This study confirms Peter Rutland's finding that this was not consensus, but a widespread support for stability over chaos and infighting (Rutland, 2018, p.282). Below this truce on the ruling coalition, infighting in a divided elite remained an essential feature of Russian policy- and decision-making: a feature shaping Russia's political economy. To rule Russia, it was still important 


\section{Introduction}

to master, and dominate, informal relations, personal relationships and informal rent sharing (Baturo and Elkink, 2016). Any regime stability is precarious, because it hinges on balancing among groups of interest. In relatively stable periods between election seasons, elite conflicts around the companies studied here often revolved around modifications of the institutional framework in a way that maximised rents, either to the state, to the companies, or both. But more fundamentally, state-company relations in the energy sphere remained significant because control of any major company had the potential to influence political survival in post-Soviet Russia.

To many elite groups, including state actors, the companies studied here were important for their resources first, and by extension for their political influence. Other company contributions to the economy, for example innovation, appear to have been seen as less significant, even uninteresting. The elites' generally positive view of the nuclear energy industry, which is more research intensive and more dependent on the state than other energy industries, is an exception in this respect. ${ }^{4}$ Russia's elites are in general oriented towards the state (Levada, 2010, p.83). This is evident in how economic power and business development is conceptualised in the case of the energy companies outside the nuclear energy industry. Companies' challenges and opportunities are not widely discussed or even understood in many elite groups. The importance for the national economy of these companies is often approached through concepts like national backwardness (Rutland, 2015, p.83). Putin's use of the term "energy superpower" or "hydrocarbon superpower", discussed in Chapter 2, represents both a departure from this general state of affairs, in emphasising the value of energy resources, and a continuation, in relating this value to the power of the state (Bouzarovski and Bassin, 2011).

The institutions that made it possible to access those resources were fundamental to such power projection. In Chapter 2, I discuss the role of energy in Russian foreign policy towards the post-Soviet region. In the case chapters that come afterwards, I return to institutional development in the energy industries and how it related to the foreign policy role of each company.

\section{Notes}

1 These concepts are also used in education and social studies, where they capture social inclusion.

2 Data available from the Observatory of Economic Complexity (https://atlas.media. mit.edu/en/). Values are calculated using current US dollars to exchange rates provided by the reporting nation.

3 Data available from the Observatory of Economic Complexity (https://atlas.media. mit.edu/en/). Values are calculated using current US dollars to exchange rates provided by the reporting nation.

4 For example, as demonstrated by public displays on the historic and current technological advances of this industry, such as those observed by the author in Moscow in April 2018. 


\section{References}

Aalto, P. et al. (2012) "How are Russian energy policies formulated? Linking the actors and structures of energy policy" in Aalto, P. ed., Russia's Energy Policies. National, Interregional and Global Levels (Cheltenham, UK/Northampton, USA: Edward Elgar), pp.20-42

Åslund, A. (1999) "Russia's collapse”, Foreign Affairs, 78 (5): 64-77

Baev, P.K. (2013) "Diversification, Russian-style: Searching for security of demand and transit" in Godzimirski, J.M. ed., Russian Energy in a Changing World. What is the Outlook for the Hydrocarbons Superpower? (Farnham: Ashgate), pp.111-129

Balmaceda, M.M. (2012) "Russia's central and eastern European energy transit corridor: Ukraine and Belarus" in Aalto, P. ed., Russia's Energy Policies. National, Interregional and Global Levels (Cheltenham, UK/Northampton, USA: Edward Elgar), pp.136-155

Balmaceda, M.M. (2013) The Politics of Energy Dependency. Ukraine, Belarus and Lithuania between Domestic Oligarchs and Russian Pressure (Toronto: University of Toronto Press)

Barkanov, B. (2018) "Natural Gas" in Tsygankov, A.P. ed., Routledge Handbook of Russian Foreign Policy (Abingdon/New York: Routledge), pp.138-152

Baturo, A. and Elkink, J.A. (2016) "Dynamics of regime personalization and patron-client networks in Russia, 1999-2014", Post-Soviet Affairs, 32 (1): 75-98

Bouzarovski, S. and Bassin, M. (2011) "Energy and identity: Imagining Russia as a hydrocarbon superpower", Annals of the Association of American Geographers, 101 (4): 783-794

Brada, J.C. (2013) "The Exchange Rate and Foreign Direct Investment" in Hare, P. and Turley, G. ed., Handbook of the Economics and Political Economy of Transition (London/New York: Routledge), pp.181-189

Bradshaw, M. (2008) “The geography of Russia's new political economy", New Political Economy, 13 (2): 193-201

Bukkvoll, T. (2003) "Putin's strategic partnership with the West: The domestic politics of Russian foreign policy", Comparative Strategy, 22 (3): 223-242

Busygina, I. and Filippov, M. (2013) "'Resource curse' and foreign policy: Explaining Russia's approach to the EU" in Godzimirski, J.M. ed., Russian Energy in a Changing World. What is the Outlook for the Hydrocarbons Superpower? (Farnham: Ashgate), pp.91-109

Closson, S. (2014) "Subsidies in Russia's gas trade" in Oxenstierna, S. and Tynkkynen, V.-P. ed., Russian Energy and Security up to 2030 (London/New York: Routledge), pp.61-76

Colton, T.J. and Holmes, S. (ed.) (2006) The State after Communism. Governance in the New Russia (Langham: Rowman \& Littlefield)

Connolly, R. (2013) The Economic Sources of Social Order Development in PostSocialist Eastern Europe (London/New York: Routledge)

Connolly, R. and Hanson, P. (2012) "Russia's accession to the World Trade Organization", Eurasian Geography and Economics, 53 (4): 479-501

Cooper, J. (2013) "The Russian economy twenty years after the end of the socialist economic system", Journal of Eurasian Studies, 4 (1): 55-64

Drabek, Z. and Benacek, V. (2013) "Trade Reorientation and Global Integration" in Hare, P. and Turley, G. ed., Handbook of the Economic and Political Economy of Transition (London/New York: Routledge), pp.167-180 


\section{Introduction}

Easter, G. (2006) "Building fiscal capacity" in Colton, T.J. and Holmes, S. ed., The State after Communism. Governance in the New Russia (Lanham: Rowman \& Littlefield), pp. $21-52$

Easter, G.M. (2012) Capital, Coercion, and Postcommunist States (Ithaca/London: Cornell University Press)

Ericson, R.E. (2013) "Command economy and its legacy" in Alexeev, M. and Weber, S. ed., The Oxford Handbook of the Russian Economy (Oxford: Oxford University Press), pp.51-85

Fish, M.S. (2005) Democracy Derailed in Russia. The Failure of Open Politics (Cambridge/ New York: Cambridge University Press)

Fortescue, S. (2006) Russia's Oil Barons and Metal Magnates. Oligarchs and the State in Transition (Basingstoke/New York: Palgrave Macmillan)

Frye, T. (2002) "Capture or exchange? Business lobbying in Russia", Europe-Asia Studies, 54 (7): 1017-1036

Gaddy, C.G. and Ickes, B.W. (2005) "Resource rents and the Russian economy", Eurasian Geography and Economics, 46 (8): 559-583

Gaddy, C.G. and Ickes, B.W. (2010) "Russia after the Global Financial Crisis", Eurasian Geography and Economics, 51 (3): 281-311

Gaddy, C.G. and Ickes, B.W. (2013) Bear Traps on Russia's Road to Modernization (London/New York: Routledge)

Gans-Morse, J. (2012) "Threats to property rights in Russia: From private coercion to state aggression”, Post-Soviet Affairs, 28 (3): 263-295

Gans-Morse, J. (2017) "Demand for law and the security of property rights: The case of post-Soviet Russia”, American Political Science Review, 111 (2): 338-359

Gaulier, G. and Zignago, S. (2010) BACI: International Trade Database at the ProductLevel. The 1994-2007 Version. CEPII Working Paper. (Paris: CEPII)

Gel'man, V. (2015) Authoritarian Russia. Analyzing Post-Soviet Regime Changes (Pittsburgh: University of Pittsburgh Press)

Guriev, S. and Rachinsky, A. (2005) "The role of oligarchs in Russian capitalism", Journal of Economic Perspectives, 19 (1): 131-150

Guriev, S. and Tsyvinskii, O. (2011) "Guriev, Tsyvinskii: Pered kem v otvete biznes [Guriev, Tsyvinskii: to whom is business accountable]", Vedomosti, 12 September 2011, Available from: https://www.vedomosti.ru/opinion/articles/2011/09/13/kompa nii_i_filantropy [Accessed 25 March 2020]

Gvosdev, N.K. and Marsh, C. (2014) Russian Foreign Policy. Interests, Vectors, and Sectors (Thousand Oaks/London: SAGE/CQ Press)

Hale, H.E. (2010) "Eurasian polities as hybrid regimes: The case of Putin's Russia", Journal of Eurasian Studies, 1 (1): 33-41

Hale, H.E. (2015) Patronal Politics. Eurasian Regime Dynamics in Comparative Perspective (New York/Cambridge: Cambridge University Press)

Hanson, P. (2003) The Rise and Fall of the Soviet Economy. An Economic History of the USSR from 1945 (Harlow: Pearson Education)

Hanson, P. (2014) Reiderstvo: Asset-grabbing in Russia. Programme papers on Russia and Eurasia. 3. (London: Chatham House)

Hanson, P. and Teague, E. (2005) "Big Business and the State in Russia", Europe-Asia Studies, 57 (5): 657-680

Hellman, J. (1998) "Winners take all: The politics of partial reform in postcommunist transitions", World Politics, 50 (2): 203-234 
Hellman, J.S., Jones, G. and Kaufmann, D. (2000) "Seize the State, Seize the Day". State Capture, Corruption, and Influence in Transition. Policy Research Working Paper. 2444. (Washington, DC: The World Bank)

Huskey, E. (2014) "Legacies and Departures in the Russian State Executive" in Beissinger, M.R. and Kotkin, S. ed., Historical Legacies of Communism in Russia and Eastern Europe (New York: Cambridge University Press), pp.111-127

IMF (2014) Russian Federation. Fiscal Transparency Evaluation. IMF Country Report. (Washington, DC: International Monetary Fund)

IMF et al. (1990) The Economy of the USSR. Summary and Recommendations. Report for Group of Seven Countries. (Washington, DC: World Bank)

Jensen, N. and Wantchekon, L. (2004) "Resource wealth and political regimes in Africa”, Comparative Political Studies, 37 (7): 816-841

Kaczmarski, M. (2014) "Domestic power relations and Russia's foreign policy", Demokratizatsiya, 22 (3): 383-409

Karl, T.L. (1997) The Paradox of Plenty: Oil Booms and Petro-States (Berkeley: University of California Press)

Kivinen, M. (2012) "Public and business actors in Russia's energy policy" in Aalto, P. ed., Russia's Energy Policies. National, Interregional and Global Levels (Cheltenham, UK/Northampton, USA: Edward Elgar), pp.45-62

Kluge, J.N. (2017) "Foreign direct investment, political risk and the limited access order", New Political Economy, 22 (1): 109-127

Kotkin, S. and Beissinger, M.R. (2014) "The historical legacies of Communism: An empirical agenda" in Beissinger, M.R. and Kotkin, S. ed., Historical Legacies of Communism in Russia and Eastern Europe (New York: Cambridge University Press), pp.1-27

Ledeneva, A.V. (2006) How Russia Really Works. The Informal Practices That Shaped Post-Soviet Politics and Business (Ithaca and London: Cornell University Press)

Ledeneva, A.V. (2013) Can Russia Modernise? Sistema, Power Networks and Informal Governance (Cambridge: Cambridge University Press)

Levada, I. (2010) "Ruling authority, the elite, and the masses", Sociological Research, 49 (2): 82-94

Luong, P.J. and Weinthal, E. (2006) "Rethinking the resource curse: Ownership structure, institutional capacity, and domestic constraints", Annual Review of Political Science, 9: 241-263

Luong, P.J. and Weinthal, E. (2010) Oil Is Not a Curse. Ownership Structure and Institutions in Soviet Successor States (Cambridge: Cambridge University Press)

Malcolm, N. (1996) "Foreign policy making" in Malcolm, N. et al. ed., Internal Factors in Russian Foreign Policy (Oxford: The Royal Institute for International Affairs/Oxford University Press), pp.101-168

Malle, S. (2013) "Economic modernisation and diversification in Russia. Constraints and challenges", Journal of Eurasian Studies, 4 (1): 78-99

Mann, M. (2012 [1993]) The Sources of Social Power (Cambridge: Cambridge University Press)

Marten, K. (2015) “Informal political networks and Putin's foreign policy”, Problems of Post-Communism, 62 (2): 71-87

Mau, V. (2016) "Between crises and sanctions: Economic policy of the Russian Federation", Post-Soviet Affairs, 32 (4): 350-377

Mau, V. (2017) "Russia's economic policy in 2015-16: The imperative of structural reform", Post-Soviet Affairs, 33 (1): 63-83 


\section{Introduction}

Meister, S. (ed.) (2013) Economization Versus Power Ambitions: Rethinking Russia's Policy Towards Post-Soviet States (Berlin: Deutsche Gesellschaft für Auswärtige Politik e.V.)

Melville, A., Stukal, D. and Mironyuk, M. (2014) "King of the Mountain', or why postcommunist autocracies have bad institutions", Russian Politics and Law, 52 (2): 7-29

Miller, C. (2018) Putinomics. Power and Money in Resurgent Russia (Chapel Hill: University of North Carolina Press)

Monaghan, A. (2012) "The vertikal: Power and authority in Russia", International Affairs, 88 (1): 1-16

Müller, M. (2015) “After Sochi 2014: Costs and impacts of Russia’s Olympic Games”, Eurasian Geography and Economics, 55 (6): 628-655

North, D.C. (1990) Institutions, Institutional Change and Economic Performance (Cambridge/New York: Cambridge University Press)

North, D.C., Wallis, J.J. and Weingast, B. (2009) Violence and Social Orders. A Conceptual Framework for Interpreting Recorded Human History (Cambridge: Cambridge University Press)

Paneyakh, E. (2014) "Faking performance together: Systems of performance evaluation in Russian enforcement agencies and production of bias and privilege", PostSoviet Affairs, 30 (2-3): 115-136

Peregudov, S.P., Lapina, N.Yu. and Semenenko, I.S. (1999) Gruppy interesov i rossiiskoe gosudarstvo [Interest groups and the Russian state] (Moscow: Editorial URSS)

Pirani, S. (ed.) (2009) Russian and CIS Gas Markets and their Impact on Europe (Oxford: Oxford Institute for Energy Studies/Oxford University Press)

Pomfret, R. (2013) "Resource-rich transition economies" in Hare, P. and Turley, G. ed., Handbook of the Economics and Political Economy of Transition (London/New York: Routledge), pp.406-417

Popov, V. (2013) "Transformational recession" in Alexeev, M. and Weber, S. ed., The Oxford Handbook of the Russian Economy (Oxford: Oxford University Press), pp.102-131

Poussenkova, N. (2012) “"The went East, they went West...': The global expansion of Russian oil companies" in Aalto, P. ed., Russia's Energy Policies. National, Interregional and Global Levels (Cheltenham: Edward Elgar), pp.185-205

Rivera, S.W. and Rivera, D.W. (2006) "The Russian elite under Putin: Militocratic or bourgeois?”, Post-Soviet Affairs, 22 (2): 125-144

Rochlitz, M. (2014) "Corporate raiding and the role of the state in Russia", PostSoviet Affairs, 30 (2-3): 89-114

Rochlitz, M. (2015) "At the crossroads: Putin's third presidential term and Russia's institutions", Political Studies Review, 13 (1): 59-68

Ross, M.L. (1999) "The political economy of the resource curse", World Politics, 51 (2): 297-322

Ross, M.L. (2001) "Does oil hinder democracy?", World Politics, 53 (3): 325-361

Ross, M.L. (2012) The Oil Curse. How Petroleum Wealth Shapes the Development of Nations (Princeton/Oxford: Princeton University Press)

Rutland, P. (ed.) (2001) Business and the State in Contemporary Russia (Boulder, CO: Westview Press)

Rutland, P. (2015) "Petronation? Oil, gas and national identity in Russia", Post-Soviet Affairs, 31 (1): 66-89

Rutland, P. (2018) "The political elite in post-Soviet Russia” in Best, H. and Higley, J. ed., The Palgrave Handbook of Political Elites (London: Palgrave Macmillan), pp.273-294 
Sakwa, R. (2008) "Putin and the Oligarchs", New Political Economy, 13 (2): 185-191

Sharlet, R. (2001) "Putin and the politics of law in Russia", Post-Soviet Affairs, 17 (3): $195-234$

Simoes, A.J.G. and Hidalgo, C.A. (2011) "The Economic Complexity Observatory: An analytical tool for understanding the dynamics of economic development" in Workshops at the Twenty-Fifth AAAI Conference on Artificial Intelligence

Smith, B. (2007) Hard Times in the Lands of Plenty. Oil Politics in Iran and Indonesia (Ithaca/London: Cornell University Press)

Stern, J.P. (2005) The Future of Russian Gas and Gazprom (Oxford: Oxford University Press/Oxford Institute for Energy Studies)

Stoner-Weiss, K. (2006) Resisting the State. Reform and Retrenchment in Post-Soviet Russia (Cambridge: Cambridge University Press)

Stulberg, A.N. (2007) Well-Oiled Diplomacy. Strategic Manipulation and Russia's Energy Statecraft in Eurasia (Albany, New York: State University of New York Press)

Stulberg, A.N. (2015) "Out of gas? Russia, Ukraine, Europe, and the changing geopolitics of natural gas”, Problems of Post-Communism, 62 (2): 112-130

Sutela, P. (2012) The Political Economy of Putin's Russia (London/New York: Routledge)

Torbakov, I. (2013) "Understanding Moscow's conduct: The analysis of the domesticforeign policy nexus in Russia" in Meister, S. ed., Economization Versus Power Ambitions: Rethinking Russia's Policy Towards Post-Soviet States (Berlin: Deutsche Gesellschaft für Auswärtige Politik e.V.), pp.19-33

Vasileva, A. (2018) "Trapped in informality: The big role of small firms in Russia's statist-patrimonial system", New Political Economy, 23 (3): 314-330

Veligzhanina, A. (2000) "Krasnaya 'krysha' vsekh kruche i vyshe [The red 'roof' is the most influential and tallest]", Komsomol'skaya pravda, 14 June 2000

Weber, Y. (2018) "Petropolitics" in Tsygankov, A.P. ed., Routledge Handbook of Russian Foreign Policy (Abingdon/New York: Routledge), pp.99-117

Wenger, A., Perovic, J. and Orttung, R.W. (ed.) (2006) Russian Business Power. The Role of Russian Business in Foreign and Security Relations (London/New York: Routledge)

Wengle, S.A. (2012) "Engineers versus managers: Experts, market-making and statebuilding in Putin's Russia", Economy and Society, 41 (3): 435-467

Wengle, S.A. (2014) Post-Soviet Power. State-led Development and Russia's Marketization (Cambridge/New York: Cambridge University Press)

Yakovlev, A. (2006) "The evolution of business-state interaction in Russia: From state capture to business capture?", Europe-Asia Studies, 58 (7): 1033-1056

Yakovlev, A., Sobolev, A. and Kazun, A. (2014) "Means of production versus means of coercion: Can Russian business limit the violence of a predatory state?", Post-Soviet Affairs, 30 (2-3): 171-194

Zudin, A.Yu. (2013) "Biznes i gosudarstvo v Rossii: opyt primeneniya podkhoda NortaUollisa-Vaingasta. Stat'ya 1. Etapy razvitiya rossiiskikh biznes-assotsiatsii [Business and the state in Russia: an attempt at applying the approach of North-Wallis-Weingast. Article 1. Stages in the development of Russian business associations]", Obshchestvennye nauki i sovremennost', 2013 (2): 15-31 


\section{Notes}

\section{Preface and acknowledgements}

1 According to some reports, the police used a circular saw. Most reports claim that the door was opened forcefully with a power tool, and they form the basis of my account here. However, at least one report claims that such force was not used.

\section{Chapter 1}

1 These concepts are also used in education and social studies, where they capture social inclusion.

2 Data available from the Observatory of Economic Complexity (https://atlas.media. mit.edu/en/). Values are calculated using current US dollars to exchange rates provided by the reporting nation.

3 Data available from the Observatory of Economic Complexity (https://atlas.media. mit.edu/en/). Values are calculated using current US dollars to exchange rates provided by the reporting nation.

4 For example, as demonstrated by public displays on the historic and current technological advances of this industry, such as those observed by the author in Moscow in April 2018.

\section{Chapter 2}

1 First government December 1992 to August 1996, second government August 1996 to March 1998.

2 As discussed in some detail in the cited report, there are some deficiencies in the data used for these calculations (Freinkman et al., 2004, pp.1-5). The unavailability of consistent price data is particularly relevant to the discussion here.

3 Due to deficiencies in trade reporting, it is generally difficult to estimate the exact value and volume of foreign trade flows among CIS member states in the period from 1992 to 1996. The UN Comtrade Database contains data from 1996 onwards. Deficient reporting and very high inflation in some states make it difficult to estimate precise values for CIS energy trade before 1996 (Belkindas and Dikhanov, 1994). For energy, widespread barter payment complicates the picture further. On this background, this chapter does not include calculations for Russia's share in energy imports for other CIS states.

4 Author's calculation based on data from the UN Comtrade Database. Energy exports calculated on the basis of export flows from Russia as reported by Russia to Armenia, Azerbaijan, Belarus, Georgia, Estonia, Kazakhstan, Kyrgyzstan, Latvia, Lithuania, Moldova, Tajikistan, Turkmenistan, Ukraine and Uzbekistan 
of goods reported under the commodity codes 2709 Petroleum oils, oils from bituminous minerals, crude; 2710 Oils petroleum, bituminous, distillates, except crude; 271121 Natural gas in gaseous state; 2716 Electrical energy; 8401 Nuclear reactors, fuel elements, isotope separators. Calculations in US\$.

5 Foreign minister January 1996 to September 1998, prime minister September 1998-May 1999.

6 Acting president 31 December 1999 to March 2000, president 2000-2008 and 2012-.

7 Defence Minister March 2001 to February 2007.

8 At its peak in September 2008, the Reserve Fund held 142.6 billion US\$, while the National Welfare Fund exceeded 80 billion US\$ in 2009. The Reserve Fund was established to offset future shortfalls in oil revenue. Having been used to cover deficits during the 2015-2017 economic crisis, the Fund was depleted by the end of 2017. In January 2018, what remained was merged with the National Welfare Fund. This Fund had been designed to cover national pensions in the mid-term. This did not prevent the government from resorting to the National Welfare Fund to meet income shortfalls.

9 Early proposals were for a pipeline through Turkey, Bulgaria, Romania and Hungary to the gas hub at Baumgarten in Austria. A later proposal, Nabucco West, included only the part from Bulgaria's border with Turkey to Baumgarten.

10 Across the Black Sea to Bulgaria, Serbia, and Hungary to Baumgarten and Slovenia, with a second leg to Greece and Italy.

\section{Chapter 3}

1 Put into use following the $8^{\text {th }}$ All-Russian Congress of Soviets in Moscow on 22-23 December 1920, which passed the plan for electrification of the whole country (Plan GOELRO).

2 UES is used here, as it corresponds to the most frequent English name for the company RAO UES. Edinaya energeticheskaya sistema is abbreviated EES in Russian. United Power System (UPS) is the most frequent translation of EES in the electricity industry.

3 Electricity grids that are connected operate synchronously, meaning that their speed and frequency match. After disconnection, they have to be brought back to exact synchronisation to exchange power.

4 Unbundling refers to the separation of different business lines of a previously integrated company. Ownership unbundling occurs when a company, often a monopoly, is divested of previously integrated assets through legislation. The aim is usually to create more competitive markets.

5 Two electricity grids operated in isolation: the Central Asian grid, which included southern, but not northern Kazakhstan, and the (Far) Eastern grid.

6 An overview of reform legislation is found at http://www.fsk-ees.ru/about/reform/ (in Russian).

7 The synchronous grid of Continental Europe was known as UCTE until 1 July 2009, when it was reorganised as the European network of Transmission System Operators (ENTSO-E).

8 As electricity trade can be effected through high-voltage, synchronous or non-synchronous DC interlinks/interconnectors, export does not necessarily depend on synchronisation.

9 Moldova TPP is sometimes known as Cuciurgan/Kuchurgan, like the adjacent lake. The Russian term for thermal power plant is GRES, originally an abbreviation of gosudarstvennaya raionnaya elektrostantsiya, meaning state regional power plant. The correct modern term is gidroretsirkulyatsionnaya elektrostantsiya, meaning hydro-recycling power plant. Many thermal power plants are designed for 
more than one fuel, with different boilers and the possibility of switching fuels depending on price and availability.

10 Razdan in Russian.

11 Initialised by Russia, Iran and India in 2002. Azerbaijan joined in 2005.

12 In Russian: NP Sovet rynka, https://www.np-sr.ru/

13 The date for unbundling and privatisation was at the time of Inter RAO's expansion in the process of being pushed forward to 2007-2008.

14 An open switch for high current circuits, now generally replaced by closed safety switches.

15 As it later emerged, they were well placed to acquire other assets. In particular, Rappoport and Vladimir Avetisyan, upon unbundling director of a substantial part of RAO UES's generation assets, took control of lesser companies in non-core industries (in e.g. power engineering). Before reform such assets appeared less interesting. After reform they were merged into major companies in their own right. RAO UES's financial advisor, Troika Dialog, organized the financial side of the equity transfers (Shmagun et al., 2019).

16 Gidro-OGK was established in 2004 as part of the electricity reform and later renamed to RusHydro (RusGidro in Russian). Dod left RusHydro unexpectedly, and again involuntarily, in August 2015. He was arrested on charges of fraud, connected to subsequent work with a RusHydro subsidiary, in July 2016.

17 GruzRosEnergo in Russian.

18 In Armenian the slogan was "Voch t'alanin", meaning "No robbery".

19 Manas was an airbase until 2009, when a renewed bilateral agreement between the US and Kyrgyzstan changed its status to a transit centre.

\section{Chapter 4}

1 Rosatom holds enterprises in the nuclear military complex directly. Nuclear construction was in 2011 incorporated in the Atomenergomash holding.

2 ARMZ was until 2008 Atomredmetzoloto, when it became Uranovyi kholding ARMZ (Uranium holding ARMZ).

3 Tekhsnabeksport operates as Tenex internationally.

4 Between 2011 and 2016, Rosatom's nuclear engineering companies NIAEP, Atomenergoproekt, Atomproekt, and Atomstroieksport were reorganized into Rosatom's engineering division ASE.

5 An overview of Russian-produced reactors, in Russia and elsewhere, can be found at http://www.world-nuclear.org/information-library/country-profiles/countries-o-s/ russia-nuclear-power.aspx

6 From civilian production and services. Rosatom's share of military expenditure is part of the non-disclosed part of the state budget.

7 An overview of reactor types, including pressurized water reactors like the Russian VVER, is found at the website of the World Nuclear Association: http://www. world-nuclear.org/

8 Minsredmash existed from 1953 to 1986. Its predecessor was Pervoe glavnoe upravlenie pri SNK (Sovet narodnykh kommissarov) SSSR, in English the First Chief Directorate. PGU was founded in 1945.

9 A golden share is a nominal share that gives an owner, often a government, direct influence over company development and an opportunity to outvote other owners on specific issues. It is an instrument associated with privatisation processes and with sectors of strategic interest to states.

10 At the time of writing, there is no indication that Russia does not keep its obligations within the international regime on non-proliferation regime in relations with Iran, but at that time, there were serious international worries about Russia's interpretation of the non-proliferation regime. 
11 Also known as HEU-LEU in English and VOU-NOU in Russian. Under the programme, which lasted from 1993 to 2013, 500 tonnes of weapons-grade Russian HEU were downblended to LEU using US natural uranium, then transported to the US for use in NPPs. This fuel supplied up to ten per cent of all US electricity in the 20-year period. The two partners in the commercial agreement were Tekhsnabeksport (Tenex) and USEC (from 2014 Centrus Energy Corp.). In an unintended consequence of the programme, the American partner USEC became dependent on Rosatom for enrichment, leaving global primary enrichment services in the hands of three companies, Rosatom, the UK-Netherlands-German company Urenco, and the French company Areva (from January 2018 Orano).

12 Orebodies in Kazakhstan are larger and the ore can be more easily extracted than in Russia's deposits. They are therefore more commercially viable.

13 Ukraine acceded to the NPT in December 1994, following the signing of the Budapest Memorandum on Security Assurances. The Memorandum provided security assurances against threats or use of force against the territorial integrity or political independence of Ukraine, Belarus and Kazakhstan on the part of the US, UK and Russia. As a consequence, Ukraine, Belarus and Kazakhstan gave up their nuclear weapons stockpiles in 1994-1996.

14 Most reactors had a licensed service life of 30 years from first power.

15 The golden share gave TVEL a veto over "unfavourable business decisions" including closure, ownership change, management change, change of business direction and decreases in production.

16 Initially, 45 per cent held by ARMZ, in 201049.67 per cent held by Uranium One.

17 Other state corporations were Vneshekonombank/VEB (foreign investment financial organisation), Rosnano (nanotechnology industry development, shareholding company from 2010), Rostekhnologii (advanced technology development), Olimpstroi (The 2014 Olympic Games in Sochi), and the Corporation for housing reform.

18 In February 2009.

19 Hydropower generation was privileged in a similar way.

20 Evstratov was later released on bail, and the court returned the case to further investigation in 2012 and again in 2014 (Barinov, 2014). The charges were withdrawn in 2016 when the investigating authority, the Central Board of Economic Security and Anti-Corruption of the Interior Ministry, was itself charged with corruption. That trial ended with convictions in 2017. This is also known as the Sugrobov case.

21 The IUEC is not to be confused with the two international nuclear fuel banks. Under the auspices of IAEA, Russia established a nuclear fuel reserve near Angarsk in 2010. Nuclear fuel is available at market rates, to any IAEA member of good standing unable to procure nuclear fuel for political reasons. In addition, IAEA controls a bank of low-enriched uranium in Kazakhstan (Ulba), operational from 2017, which can be made available to any IAEA member that finds it difficult to secure supply of LEU.

22 Dzhakishev had been cleared of similar charges in 2007.

23 Shkolnik was born in Russia, and his son was married to the daughter of Vadim Zhivov, then head of ARMZ (now Uranium One) and responsible for Rosatom's contacts with Kazatomprom.

24 Following Dzhakishev's arrest, Uranium One shares traded down by a third before being suspended from the Toronto stock exchange.

25 From October 2006 Westinghouse-Toshiba following the acquisition of 77 per cent of Westinghouse's shares by Toshiba. This was reduced to 67 per cent in 2007, when a 10 per cent stake was sold to Kazatomprom.

26 Novokonstantinovka in Russian.

27 Ostrovets in Russian. 
28 Cameco is the only other uranium producer that is a public company.

29 The acting CEO in 2013-2014, Nikita Konstantinov, in 2015 took up a position in the Rosatom subsidiary Rusatom International.

30 Had this happened, it would have been a similar development to relations between Gazprom and Naftogaz at the same time. Interestingly, TVEL did not pursue this course of action.

\section{Chapter 5}

1 The Norwegian company Statoil (est. 1972) in 2018 changed its name to Equinor.

2 In the petroleum industry, storage and transport are designated as "midstream" activities. Here, only the terms "upstream" and "downstream" are used, and storage and transport are included with downstream activities.

3 Production associations formed the operational level in the Soviet oil and gas industries. A production association could be comprised of one or more fields, with often substantial production.

4 An all-union Oil Industry Ministry was established in 1939, while the all-union Gas Industry Ministry was established in 1965. The two were merged to become the Ministry for the Oil and Gas Industries in 1989.

5 Mažeikiu dropped out of the project when it became clear that the Soviet Union would break up, and the refinery became Lithuanian property. It did not figure in the government resolution. Ufa did not remain with Lukoil after it became vertically integrated in 1993.

6 Yukos and Surgutneftegaz were the two others.

7 The state's share was 53.2 per cent until 1995, 26.2 per cent by 1999, 15.5 in 2000 and 7.59 in 2002-2004.

8 In a production sharing agreement (PSA) or production sharing contract (PSC), a government awards a company the right to explore and produce a resource from a given field or region, at the company's own risk. If and when costs are recovered, subsequent profits are divided between the government and the company according to the contract. PSAs are used by many governments, especially those new to the global petroleum industry, or in countries associated with high (political) risk. Unlike concessions, they are seen to create a legal enclave in which the contract regulates all relations between the parties. Once signed, they are subject to change only by mutual consent, and therefore alleviate risk for the company. In practise, they are often governed by general legislation, and disputes tend to arise when a specific contract does not align with other legislation. The term PSA is best known outside the industry and is used here.

9 Situated in Navapolatsk (Belarusian)/Novopolotsk (Russian).

10 In 2004, this ministry became a federal agency, Rosimushchestvo.

11 With a government prerogative to veto important management decisions, have a designated place on the Board, and access all internal documents.

12 The Russian government had three representatives on the Board in 1999-2000 (elections were held at shareholder meetings in June), two in 2000-2003 and one in 2003-2005.

13 ONAKO ended up with TNK, later TNK-BP (from 2013 Rosneft).

14 In 2007, Uzbek gas fetched 100 US\$ per thousand cubic metres, while Lukoil's Russian gas fetched 40 US\$.

15 In 2005, Alekperov held a share of approximately 13\%. In the following four to five years, the combined management share increased to above 32 per cent, around 20 of which were held by Alekperov. In 2017, the top management of 14 people, including Alekperov, owned 23.97 per cent of the company, while the members of the Board of Directors, including Alekperov, controlled 33.79 per cent of the company. Alekperov owned 23.13 per cent (Lukoil, 2018a, pp.36-39). 
16 In 2003, Lukoil produced 78.6 million tonnes of oil and gas condensate in Russia, and in 200991.9 million tonnes, with a gradual increase in the years in between (numbers from combined annual reports).

17 Numbers exclude exports to the CIS.

18 In the event, it reached 20.5 per cent in 2017 (Lukoil, 2018a, p.15).

19 Lukoil's stake was reduced from 15 to 13.5 per cent. The financial compensation from KazMunayGaz for its new 10 per cent stake was to be paid out over three years.

20 The other members were Russia, Belarus, Kazakhstan, Kyrgyzstan and Tajikistan.

21 According to Energy Minister Aleksandr Novak, the deal brought Russia an estimated 6 trillion rubles in additional revenue over its two years' duration in 20172018, in addition to 2 to 2.5 trillion rubles to Russia's oil companies in the same period (Oilcapital.ru, 2019b). For comparison, Russia's actual total revenue in 2017 was 15.26 trillion rubles.

22 This turn of events would later in 2016 serve as the background for the corruption accusations against then Minister of Economic Development, Aleksei Ulyukaev, for which he was convicted in 2017.

\section{Chapter 6}

1 Urals is the main crude oil blend in Russia, and a benchmark quality in global oil markets. It is a blend of heavy, sour oil from the Volga and Urals regions and light crudes from West Siberia.

2 This was the extent of the pipeline system after disintegration of oil products pipelines and non-Russian pipelines.

3 In a swap, oil delivered in one place is traded in for oil sold somewhere else, to minimise transport costs.

4 Supergiant fields have in excess of 1 billion barrels ultimately recoverable proven oil reserves or (for gas) oil equivalents.

5 This was the date confirmed by the Duma as per the ordinary election schedule (the previous presidential elections having been held in June 1996). When Yeltsin resigned on 31 December 1999, the election law required that elections be held within three months, and the election was pushed forward to 26 March.

6 Zarubezhneft, established in 1967, only had operations abroad. In 2000, its main activity was a joint venture in Vietnam.

7 The routes were Groznyi-Lysychansk and Samara-West.

8 In Russian: Vostochnaya Sibir-Tikhii Okean (VSTO).

9 In November 2017, Rosneft suggested the possibility of reopening the project and developing Indiga as terminal for oil and LNG from Timan-Pechora, but this was related to a business dispute with Lukoil and not pursued for long.

10 Pivdennyi terminal is Yuzhnyi terminal in Russian, meaning South terminal in English.

11 It was acquired by the Vitol Group in 2006.

12 The route was Vtorovo-Yaroslavl-Kirishi-Primorsk.

13 Crude oil quality is normally determined by sulphur content and gravity, and influences price considerably.

14 The $2228 \mathrm{~km}$ long pipeline goes from Atyrau by the Caspian Sea through Aktobe, Kenkiyak, Kumkol and Atasu to Alashankou on the Kazakhstan-China border. There it connects to the Alashankou-Dushanzi pipeline, completed in December 2005, which supplies a large refinery. The final leg on Kazakhstan's side, AtasuAlashankou, serves China only.

15 FST existed from 2004 to 2015. It inherited the task of overseeing tariffs in the energy industries from the Federal Energy Commission (1992-2005). In 2015, the Federal Anti-Monopoly Service was placed in charge of these tasks.

16 In the first round of Western sanctions against Russian politicians and businessmen in March 2014, Timchenko was subjected to personal sanctions (asset freeze and 
denial of access to transactions) by the US, Canada and Australia. The US Treasury's grounds for designating Timchenko were that his "activities in the energy sector have been directly linked to Putin. Putin has investments in Gunvor and may have access to Gunvor funds" (US Department of the Treasury, 2014).

17 At average exchange rates for 2011. Annual average exchange rate for Euro for 2011 was 40.88 RUB/1 EUR (Statista, 2019). Annual average exchange rate for US\$ for 2011 was 29.406 RUB/1 US\$ (OzForex, 2019).

18 http://www.mbfk.ru/

19 In the event, the APEC summit fell short of expectations, and the local construction boom ahead of the summit was mired in corruption scandals (Nezavisimaya gazeta, 2012). The sea life centre opened in 2016 (Primorskii okeanarium, 2019).

20 In RSBU, there are strict rules as to how accounts must be presented, and what needs to be included or excluded, facilitating controls, taxation, and comparisons between companies. IFRS are principles-based and therefore give companies more flexibility in their reporting, but necessitate more information on a company's financial situation and accordingly hold greater information value for shareholders. Crucially, RSBU do not require integrated holdings to report consolidated financial reports, and large corporations may therefore report profits under RSBU only for the head company (cf. Wikipedia, 2019).

\section{Chapter 7}

1 Until 2003, Novafininvest.

2 Associated gas is conventional gas that is produced during the extraction of crude oil. When the necessary infrastructure exists, selling it is an alternative to both flaring (burning to release the pressure) and reinjection into the field to maintain pressure and ultimately improve oil recovery rates.

3 In Russian Edinaya sistema gazosnabzheniya, ESG.

4 Under a take-or-pay clause (or take-or-pay contract), a buyer is obliged to take a certain volume of gas or pay a penalty for the shortfall. This provision reduces risk and can therefore also reduce the price, but it also represents a barrier to competition, particularly when combined with long-term contracts. Such clauses are especially common in gas trade, and uncommon outside the energy industries.

5 The Commonwealth of Independent States is comprised of all the post-Soviet states except Estonia, Latvia and Lithuania.

6 The project faltered due to US objections.

7 Turkmenistan exported around $40 \mathrm{bcm}$ annually to Ukraine by 2007.

8 The term referred to a price level similar to that of Gazprom's European customers, minus transportation costs.

9 The exception was LNG exported to Asian markets.

10 The proposed route was from Ahiboz outside Ankara to Baumgarten in Austria, with a feeder pipeline from Erzurum to Ahiboz.

11 There were four main projects, Gissarneftegaz, Kokdumalak-Gaz, Shakhpakhty and Ustyurt, with total estimated gas reserves of around $320 \mathrm{bcm}$ and oil reserves of around 20 million tonnes.

12 More evidence in support of this claim emerged during the Telia case (2013-2019), which exposed corrupt dealings between the Swedish telecommunications company TeliaSonera and several Uzbek companies, including Zeromax.

13 Data available from the Observatory of Economic Complexity (https://atlas.media. mit.edu/en/) (Simoes and Hidalgo, 2011). Values are calculated using current US dollars to exchange rates provided by the reporting nation.

14 Due to difficulties in obtaining statistics on the value of trade between Turkmenistan and Iran, it is difficult to estimate precisely the importance of China in Turkmenistan's overall trade. 
15 The most significant other gas producers were Novatek, Lukoil, Rosneft and Surgutneftegaz.

16 Investment for Gazprom group as a whole, including Gazprom Neft and other subsidiaries.

17 Value of total spending on investment from (Kardaś, 2018), value of gasification programme spending from (Gazprom, 2019a). All numbers are ultimately derived from Gazprom.

18 Shortly afterwards, one of the authors behind the report left Sberbank CIB by mutual consent, as did his immediate superior.

19 Market capitalisation is the value of a company's outstanding shares (shares held by investors, not the company).

20 Calculated using Gazprom's consolidated tax payments, consisting of tax on profits and other taxes.

21 Aleksei Miller was in April 2018 added to the US list of persons subjected to personal sanctions in relation to the war in Ukraine.

22 While the reservation mentioned in fn.14 above obtains in general also after 2016, gas export to Iran stopped in January 2017. For this reason the numbers for 2017 are more accurate. Data available at The Observatory of Economic Complexity (https://atlas.media.mit.edu/en/) (Simoes and Hidalgo, 2011). Values are calculated using current US dollars to exchange rates provided by the reporting nation. 


\section{References}

Aalto, P. et al. (2012) "How are Russian energy policies formulated? Linking the actors and structures of energy policy" in Aalto, P. ed., Russia's Energy Policies. National, Interregional and Global Levels (Cheltenham, UK/Northampton, USA: Edward Elgar), pp.20-42

Åslund, A. (1999) "Russia's collapse”, Foreign Affairs, 78 (5): 64-77

Baev, P.K. (2013) "Diversification, Russian-style: Searching for security of demand and transit" in Godzimirski, J.M. ed., Russian Energy in a Changing World. What is the Outlook for the Hydrocarbons Superpower? (Farnham: Ashgate), pp.111-129

Balmaceda, M.M. (2012) "Russia's central and eastern European energy transit corridor: Ukraine and Belarus" in Aalto, P. ed., Russia's Energy Policies. National, Interregional and Global Levels (Cheltenham, UK/Northampton, USA: Edward Elgar), pp.136-155

Balmaceda, M.M. (2013) The Politics of Energy Dependency. Ukraine, Belarus and Lithuania between Domestic Oligarchs and Russian Pressure (Toronto: University of Toronto Press)

Barkanov, B. (2018) "Natural Gas" in Tsygankov, A.P. ed., Routledge Handbook of Russian Foreign Policy (Abingdon/New York: Routledge), pp.138-152

Baturo, A. and Elkink, J.A. (2016) "Dynamics of regime personalization and patron-client networks in Russia, 1999-2014”, Post-Soviet Affairs, 32 (1): 75-98

Bouzarovski, S. and Bassin, M. (2011) "Energy and identity: Imagining Russia as a hydrocarbon superpower", Annals of the Association of American Geographers, 101 (4): 783-794

Brada, J.C. (2013) "The Exchange Rate and Foreign Direct Investment" in Hare, P. and Turley, G. ed., Handbook of the Economics and Political Economy of Transition (London/New York: Routledge), pp.181-189

Bradshaw, M. (2008) "The geography of Russia's new political economy", New Political Economy, 13 (2): 193-201

Bukkvoll, T. (2003) "Putin's strategic partnership with the West: The domestic politics of Russian foreign policy", Comparative Strategy, 22 (3): 223-242

Busygina, I. and Filippov, M. (2013) "Resource curse' and foreign policy: Explaining Russia's approach to the EU" in Godzimirski, J.M. ed., Russian Energy in a Changing World. What is the Outlook for the Hydrocarbons Superpower? (Farnham: Ashgate), pp.91-109 
Closson, S. (2014) "Subsidies in Russia's gas trade" in Oxenstierna, S. and Tynkkynen, V.-P. ed., Russian Energy and Security up to 2030 (London/New York: Routledge), pp.61-76

Colton, T.J. and Holmes, S. (ed.) (2006) The State after Communism. Governance in the New Russia (Langham: Rowman \& Littlefield)

Connolly, R. (2013) The Economic Sources of Social Order Development in PostSocialist Eastern Europe (London/New York: Routledge)

Connolly, R. and Hanson, P. (2012) "Russia's accession to the World Trade Organization", Eurasian Geography and Economics, 53 (4): 479-501

Cooper, J. (2013) "The Russian economy twenty years after the end of the socialist economic system", Journal of Eurasian Studies, 4 (1): 55-64

Drabek, Z. and Benacek, V. (2013) "Trade Reorientation and Global Integration" in Hare, P. and Turley, G. ed., Handbook of the Economic and Political Economy of Transition (London/New York: Routledge), pp.167-180

Easter, G. (2006) "Building fiscal capacity" in Colton, T.J. and Holmes, S. ed., The State after Communism. Governance in the New Russia (Lanham: Rowman \& Littlefield), pp.21-52

Easter, G.M. (2012) Capital, Coercion, and Postcommunist States (Ithaca/London: Cornell University Press)

Ericson, R.E. (2013) "Command economy and its legacy" in Alexeev, M. and Weber, S. ed., The Oxford Handbook of the Russian Economy (Oxford: Oxford University Press), pp.51-85

Fish, M.S. (2005) Democracy Derailed in Russia. The Failure of Open Politics (Cambridge/ New York: Cambridge University Press)

Fortescue, S. (2006) Russia's Oil Barons and Metal Magnates. Oligarchs and the State in Transition (Basingstoke/New York: Palgrave Macmillan)

Frye, T. (2002) "Capture or exchange? Business lobbying in Russia", Europe-Asia Studies, 54 (7): 1017-1036

Gaddy, C.G. and Ickes, B.W. (2005) "Resource rents and the Russian economy", Eurasian Geography and Economics, 46 (8): 559-583

Gaddy, C.G. and Ickes, B.W. (2010) "Russia after the Global Financial Crisis", Eurasian Geography and Economics, 51 (3): 281-311

Gaddy, C.G. and Ickes, B.W. (2013) Bear Traps on Russia's Road to Modernization (London/New York: Routledge)

Gans-Morse, J. (2012) "Threats to property rights in Russia: From private coercion to state aggression", Post-Soviet Affairs, 28 (3): 263-295

Gans-Morse, J. (2017) "Demand for law and the security of property rights: The case of post-Soviet Russia”, American Political Science Review, 111 (2): 338-359

Gaulier, G. and Zignago, S. (2010) BACI: International Trade Database at the ProductLevel. The 1994-2007 Version. CEPII Working Paper. (Paris: CEPII)

Gel'man, V. (2015) Authoritarian Russia. Analyzing Post-Soviet Regime Changes (Pittsburgh: University of Pittsburgh Press)

Guriev, S. and Rachinsky, A. (2005) "The role of oligarchs in Russian capitalism", Journal of Economic Perspectives, 19 (1): 131-150

Guriev, S. and Tsyvinskii, O. (2011) "Guriev, Tsyvinskii: Pered kem v otvete biznes [Guriev, Tsyvinskii: to whom is business accountable]", Vedomosti, 12 September 2011, Available from: https://www.vedomosti.ru/opinion/articles/2011/09/13/kompa nii_i_filantropy [Accessed 25 March 2020] 
Gvosdev, N.K. and Marsh, C. (2014) Russian Foreign Policy. Interests, Vectors, and Sectors (Thousand Oaks/London: SAGE/CQ Press)

Hale, H.E. (2010) "Eurasian polities as hybrid regimes: The case of Putin's Russia", Journal of Eurasian Studies, 1 (1): 33-41

Hale, H.E. (2015) Patronal Politics. Eurasian Regime Dynamics in Comparative Perspective (New York/Cambridge: Cambridge University Press)

Hanson, P. (2003) The Rise and Fall of the Soviet Economy. An Economic History of the USSR from 1945 (Harlow: Pearson Education)

Hanson, P. (2014) Reiderstvo: Asset-grabbing in Russia. Programme papers on Russia and Eurasia. 3. (London: Chatham House)

Hanson, P. and Teague, E. (2005) "Big Business and the State in Russia", Europe-Asia Studies, 57 (5): 657-680

Hellman, J. (1998) "Winners take all: The politics of partial reform in postcommunist transitions", World Politics, 50 (2): 203-234

Hellman, J.S., Jones, G. and Kaufmann, D. (2000) "Seize the State, Seize the Day". State Capture, Corruption, and Influence in Transition. Policy Research Working Paper. 2444. (Washington, DC: The World Bank)

Huskey, E. (2014) "Legacies and Departures in the Russian State Executive" in Beissinger, M.R. and Kotkin, S. ed., Historical Legacies of Communism in Russia and Eastern Europe (New York: Cambridge University Press), pp.111-127

IMF (2014) Russian Federation. Fiscal Transparency Evaluation. IMF Country Report. (Washington, DC: International Monetary Fund)

IMF et al. (1990) The Economy of the USSR. Summary and Recommendations. Report for Group of Seven Countries. (Washington, DC: World Bank)

Jensen, N. and Wantchekon, L. (2004) "Resource wealth and political regimes in Africa”, Comparative Political Studies, 37 (7): 816-841

Kaczmarski, M. (2014) "Domestic power relations and Russia's foreign policy", Demokratizatsiya, 22 (3): 383-409

Karl, T.L. (1997) The Paradox of Plenty: Oil Booms and Petro-States (Berkeley: University of California Press)

Kivinen, M. (2012) "Public and business actors in Russia's energy policy" in Aalto, P. ed., Russia's Energy Policies. National, Interregional and Global Levels (Cheltenham, UK/Northampton, USA: Edward Elgar), pp.45-62

Kluge, J.N. (2017) "Foreign direct investment, political risk and the limited access order", New Political Economy, 22 (1): 109-127

Kotkin, S. and Beissinger, M.R. (2014) "The historical legacies of Communism: An empirical agenda" in Beissinger, M.R. and Kotkin, S. ed., Historical Legacies of Communism in Russia and Eastern Europe (New York: Cambridge University Press), pp.1-27

Ledeneva, A.V. (2006) How Russia Really Works. The Informal Practices That Shaped Post-Soviet Politics and Business (Ithaca and London: Cornell University Press)

Ledeneva, A.V. (2013) Can Russia Modernise? Sistema, Power Networks and Informal Governance (Cambridge: Cambridge University Press)

Levada, I. (2010) "Ruling authority, the elite, and the masses", Sociological Research, 49 (2): 82-94

Luong, P.J. and Weinthal, E. (2006) "Rethinking the resource curse: Ownership structure, institutional capacity, and domestic constraints", Annual Review of Political Science, 9: 241-263 
Luong, P.J. and Weinthal, E. (2010) Oil Is Not a Curse. Ownership Structure and Institutions in Soviet Successor States (Cambridge: Cambridge University Press)

Malcolm, N. (1996) "Foreign policy making" in Malcolm, N. et al. ed., Internal Factors in Russian Foreign Policy (Oxford: The Royal Institute for International Affairs/Oxford University Press), pp.101-168

Malle, S. (2013) "Economic modernisation and diversification in Russia. Constraints and challenges", Journal of Eurasian Studies, 4 (1): 78-99

Mann, M. (2012 [1993]) The Sources of Social Power (Cambridge: Cambridge University Press)

Marten, K. (2015) "Informal political networks and Putin's foreign policy", Problems of Post-Communism, 62 (2): 71-87

Mau, V. (2016) "Between crises and sanctions: Economic policy of the Russian Federation", Post-Soviet Affairs, 32 (4): 350-377

Mau, V. (2017) "Russia's economic policy in 2015-16: The imperative of structural reform", Post-Soviet Affairs, 33 (1): 63-83

Meister, S. (ed.) (2013) Economization Versus Power Ambitions: Rethinking Russia's Policy Towards Post-Soviet States (Berlin: Deutsche Gesellschaft für Auswärtige Politik e.V.)

Melville, A., Stukal, D. and Mironyuk, M. (2014) "'King of the Mountain', or why postcommunist autocracies have bad institutions", Russian Politics and Law, 52 (2): 7-29

Miller, C. (2018) Putinomics. Power and Money in Resurgent Russia (Chapel Hill: University of North Carolina Press)

Monaghan, A. (2012) "The vertikal: Power and authority in Russia", International Affairs, 88 (1): 1-16

Müller, M. (2015) “After Sochi 2014: Costs and impacts of Russia’s Olympic Games”, Eurasian Geography and Economics, 55 (6): 628-655

North, D.C. (1990) Institutions, Institutional Change and Economic Performance (Cambridge/New York: Cambridge University Press)

North, D.C., Wallis, J.J. and Weingast, B. (2009) Violence and Social Orders. A Conceptual Framework for Interpreting Recorded Human History (Cambridge: Cambridge University Press)

Paneyakh, E. (2014) "Faking performance together: Systems of performance evaluation in Russian enforcement agencies and production of bias and privilege", PostSoviet Affairs, 30 (2-3): 115-136

Peregudov, S.P., Lapina, N.Yu. and Semenenko, I.S. (1999) Gruppy interesov i rossiiskoe gosudarstvo [Interest groups and the Russian state] (Moscow: Editorial URSS)

Pirani, S. (ed.) (2009) Russian and CIS Gas Markets and their Impact on Europe (Oxford: Oxford Institute for Energy Studies/Oxford University Press)

Pomfret, R. (2013) "Resource-rich transition economies" in Hare, P. and Turley, G. ed., Handbook of the Economics and Political Economy of Transition (London/New York: Routledge), pp.406-417

Popov, V. (2013) "Transformational recession" in Alexeev, M. and Weber, S. ed., The Oxford Handbook of the Russian Economy (Oxford: Oxford University Press), pp.102-131

Poussenkova, N. (2012) “"The went East, they went West...': The global expansion of Russian oil companies" in Aalto, P. ed., Russia's Energy Policies. National, Interregional and Global Levels (Cheltenham: Edward Elgar), pp.185-205

Rivera, S.W. and Rivera, D.W. (2006) "The Russian elite under Putin: Militocratic or bourgeois?”, Post-Soviet Affairs, 22 (2): 125-144 
Rochlitz, M. (2014) "Corporate raiding and the role of the state in Russia", PostSoviet Affairs, 30 (2-3): 89-114

Rochlitz, M. (2015) "At the crossroads: Putin's third presidential term and Russia's institutions", Political Studies Review, 13 (1): 59-68

Ross, M.L. (1999) "The political economy of the resource curse", World Politics, 51 (2): $297-322$

Ross, M.L. (2001) "Does oil hinder democracy?", World Politics, 53 (3): 325-361

Ross, M.L. (2012) The Oil Curse. How Petroleum Wealth Shapes the Development of Nations (Princeton/Oxford: Princeton University Press)

Rutland, P. (ed.) (2001) Business and the State in Contemporary Russia (Boulder, CO: Westview Press)

Rutland, P. (2015) "Petronation? Oil, gas and national identity in Russia", Post-Soviet Affairs, 31 (1): 66-89

Rutland, P. (2018) "The political elite in post-Soviet Russia” in Best, H. and Higley, J. ed., The Palgrave Handbook of Political Elites (London: Palgrave Macmillan), pp.273-294

Sakwa, R. (2008) "Putin and the Oligarchs", New Political Economy, 13 (2): 185-191

Sharlet, R. (2001) "Putin and the politics of law in Russia", Post-Soviet Affairs, 17 (3): $195-234$

Simoes, A.J.G. and Hidalgo, C.A. (2011) "The Economic Complexity Observatory: An analytical tool for understanding the dynamics of economic development" in Workshops at the Twenty-Fifth AAAI Conference on Artificial Intelligence

Smith, B. (2007) Hard Times in the Lands of Plenty. Oil Politics in Iran and Indonesia (Ithaca/London: Cornell University Press)

Stern, J.P. (2005) The Future of Russian Gas and Gazprom (Oxford: Oxford University Press/Oxford Institute for Energy Studies)

Stoner-Weiss, K. (2006) Resisting the State. Reform and Retrenchment in Post-Soviet Russia (Cambridge: Cambridge University Press)

Stulberg, A.N. (2007) Well-Oiled Diplomacy. Strategic Manipulation and Russia's Energy Statecraft in Eurasia (Albany, New York: State University of New York Press)

Stulberg, A.N. (2015) "Out of gas? Russia, Ukraine, Europe, and the changing geopolitics of natural gas", Problems of Post-Communism, 62 (2): 112-130

Sutela, P. (2012) The Political Economy of Putin's Russia (London/New York: Routledge)

Torbakov, I. (2013) "Understanding Moscow's conduct: The analysis of the domesticforeign policy nexus in Russia" in Meister, S. ed., Economization Versus Power Ambitions: Rethinking Russia's Policy Towards Post-Soviet States (Berlin: Deutsche Gesellschaft für Auswärtige Politik e.V.), pp.19-33

Vasileva, A. (2018) "Trapped in informality: The big role of small firms in Russia's statist-patrimonial system", New Political Economy, 23 (3): 314-330

Veligzhanina, A. (2000) 'Krasnaya 'krysha' vsekh kruche i vyshe [The red 'roof' is the most influential and tallest]", Komsomol'skaya pravda, 14 June 2000

Weber, Y. (2018) "Petropolitics" in Tsygankov, A.P. ed., Routledge Handbook of Russian Foreign Policy (Abingdon/New York: Routledge), pp.99-117

Wenger, A., Perovic, J. and Orttung, R.W. (ed.) (2006) Russian Business Power. The Role of Russian Business in Foreign and Security Relations (London/New York: Routledge)

Wengle, S.A. (2012) "Engineers versus managers: Experts, market-making and statebuilding in Putin's Russia", Economy and Society, 41 (3): 435-467 
Wengle, S.A. (2014) Post-Soviet Power. State-led Development and Russia's Marketization (Cambridge/New York: Cambridge University Press)

Yakovlev, A. (2006) "The evolution of business-state interaction in Russia: From state capture to business capture?", Europe-Asia Studies, 58 (7): 1033-1056

Yakovlev, A., Sobolev, A. and Kazun, A. (2014) "Means of production versus means of coercion: Can Russian business limit the violence of a predatory state?", Post-Soviet Affairs, 30 (2-3): 171-194

Zudin, A.Yu. (2013) "Biznes i gosudarstvo v Rossii: opyt primeneniya podkhoda NortaUollisa-Vaingasta. Stat'ya 1. Etapy razvitiya rossiiskikh biznes-assotsiatsii [Business and the state in Russia: an attempt at applying the approach of North-Wallis-Weingast. Article 1. Stages in the development of Russian business associations]", Obshchestvennye nauki i sovremennost', 2013 (2): 15-31

Anex, R.P. (2002) "Restructuring and privatizing electricity industries in the Commonwealth of Independent States", Energy Policy, 30 (5): 397-408

Arbatov, A.G. (1993) "Russia's foreign policy alternatives", International Security, 18 (2): 5-43

Becker, A.S. (1996) "Russia and economic integration in the CIS", Survival, 38 (4 (Winter 1996-1997)): 117-136

Belkindas, M. and Dikhanov, Y. (1994) "Appendix: Foreign trade statistics in the Former Soviet Union” in Michalopoulos, C. and Tarr, D.G. ed., Trade in the New Independent States (Washington, DC: The World Bank/UNDP), pp.21-27

Closson, S. (2011) "A comparative analysis on energy subsidies in Soviet and Russian policy", Journal of Communist and Post-Communist Studies, 44 (4): 343-356

Closson, S. (2014) "Subsidies in Russia's gas trade" in Oxenstierna, S. and Tynkkynen, V.-P. ed., Russian Energy and Security up to 2030 (London/New York: Routledge), pp.61-76

Crane, K., Peterson, D.J. and Oliker, O. (2005) "Russian investment in the Commonwealth of Independent States", Eurasian Geography and Economics, 46 (6): 405-444

Dabrowski, M. (1993) Two Years of Economic Reform in Russia. Main Results. (Warsaw: CASE - Center for Social and Economic Research)

Decree No. 472 (07/05/1995) Ob osnovnykh napravleniyakh energeticheskoi politiki $i$ strukturnoi perestroiki toplivno-energeticheskogo kompleksa Rossiiskoi Federatsii na period do 2010 goda [On the basic directions of energy policy and structural reorganisation for the fuel and energy complex of the Russian Federation to 2010] (Moscow: President of the Russian Federation)

Decree No. 940 (14/09/1995) Ob utverzhdenii strategicheskogo kursa Rossiiskoi Federatsii s gosudarstvami-uchastnikami Sodruzhestva Nezavisimykh Gosudarstv [In confirmation of the Russian Federation's strategic course towards the participant states in the Commonwealth of Independent States] (Moscow: President of the Russian Federation)

Diplomaticheskii vestnik (1992) "Kolonka redaktora [From the Editor]", Diplomaticheskii vestnik, 1992 (1): 2

Dodsworth, J.R., Mathieu, P.H. and Shiells, C.H. (2002) Cross-Border Issues in Energy Trade in the CIS Countries. IMF Policy Discussion Paper. (Washington, DC: International Monetary Fund)

Drabek, Z. and Benacek, V. (2013) "Trade reorientation and global integration" in Hare, P. and Turley, G. ed., Handbook of the Economic and Political Economy of Transition (London/New York: Routledge), pp.167-180 
Dunlop, J.B. (1997) "Russia: In search of an identity?" in Bremmer, I. and Taras, R. ed., New States, New Politics. Building the Post-Soviet Nations (Cambridge/New York: Cambridge University Press), pp.29-95

Finon, D. and Locatelli, C. (2008) "Russian and European gas interdependence: Could contractual trade channel geopolitics?", Energy Policy, 36 (1): $423-442$

Freinkman, L.M., Polyakov, E. and Revenco, C. (2004) Trade Performance and Regional Integration of the CIS Countries. World Bank Working Paper, 38 (Washington, DC: World Bank Publications)

Gentile, M. (2015) "The Post-Soviet urban poor and where they live: Khrushchev-era blocks, "bad" areas, and the vertical dimension in Luhansk, Ukraine", Annals of the Association of American Geographers, 105 (3): 583-603

Guedes Vieira, A.V. (2016) "Eurasian integration: Elite perspectives before and after the Ukraine crisis", Post-Soviet Affairs, 32 (6): 566-580

Guillet, J. (2011) "How to get a pipeline built: Myth and reality" in Dellecker, A. and Gomart, T. ed., Russian Energy Security and Foreign Policy (London/New York: Routledge), pp.58-73

Harsem, Ø. and Claes, D.H. (2013) "The interdependence of European-Russian energy relations", Energy Policy, 59: 784-791

IEA (2016) Online Data Services, Issue date [online]. Published by International Energy Agency. Available from: http://www.iea.org/statistics/ [Accessed 13 October 2016]

IMF (2007) Russian Federation. Staff Report for the 2007 Article IV Consultation. IMF Country Report No. 351. (Washington, DC: International Monetary Fund)

IMF (2016) Russian Federation. Staff Report for the 2016 Article IV Consultation. IMF Country Report No. 16/229. (Washington, DC: International Monetary Fund)

Just, T. (2016) "Promoting Russia abroad: Russia's post-Cold war national identity and public diplomacy", Journal of International Communication, 22 (1): 82-95

Katz, M.N. (2006) "Primakov redux? Putin's pursuit of 'multipolarism' in Asia", Demokratizatsiya, 14 (1): 144-152

Konoplyanik, A. et al. (ed.) (1992) Neft' i gaz vo vneshnei politike Rossii [Oil and gas in Russia's foreign policy] (Moscow: Fond vneshnei politiki)

Korsun, Yu. (1994) "Energeticheskaya strategiya Rossii do 2010 g [Russia's energy strategy until 2010]”, Obozrevatel' [Observer], 1994 (16-17 and 19-20)

Kozyrev, A. (1992) "Russia: A chance for survival", Foreign Affairs, 71 (2): 1-16

Kremlin.ru (2006) Stenograficheskiy otchet o vstreche s uchastnikami tret'ego zasedaniya Mezhdunarodnogo diskussionnogo kluba "Valdai" [Shorthand report from meeting with participants in the third meeting of the International Discussion Club Valdai] (Moscow: Kremlin.ru)

Kudaibergenova, D. (2016) "Eurasian Economic Union integration in Kazakhstan and Kyrgyzstan", European Politics and Society, 17 (S1): 97-112

Kuzio, T. (2005) "Russian policy towards Ukraine during elections", Demokratizatsiya, 13 (4): 491-517

Libman, A. (2007) "Regionalisation and regionalism in the post-Soviet space: Current status and implications for institutional development", Europe-Asia Studies, 59 (3): 401-430

Libman, A. and Kheifets, B.A. (2007) "Korporativnaya model' regional'noi ekonomicheskoi integratsii [The corporate model of regional economic integration]", Mirovaya ekonomika i mezhdunarodnye otnosheniya, 2007 (3): 15-22 
Light, M. (1996) "Foreign policy thinking" in Malcolm, N. et al. eds., Internal Factors in Russian Foreign Policy (Oxford: The Royal Institute for International Affairs/ Oxford University Press), pp.33-100

Meister, S. (ed.) (2013) Economization Versus Power Ambitions: Rethinking Russia's Policy Towards Post-Soviet States (Berlin: Deutsche Gesellschaft für Auswärtige Politik e.V.)

Michalopoulos, C. and Tarr, D.G. (1994) Trade in the New Independent States. Studies of Economies in Transformation (Washington, DC: The World Bank/UNDP)

Ministry of Energy (2009) Energeticheskaya strategiya Rossii na period do 2030 goda [Russia's Energy Strategy for the period to 2030] (Moscow: Institute of Energy Strategy)

Ministry of Foreign Affairs (1993) Kontseptsiya vneshnei politiki Rossiiskoi Federatsii [Foreign policy concept of the Russian Federation] (Moscow: Diplomaticheskii vestnik)

Ministry of Foreign Affairs (2007) Obzor vneshnei politiki Rossiiskoi Federatsii [An overview of the foreign policy of the Russian Federation] (Moscow: Ministerstvo Inostrannykh Del (MID))

Ministry of Foreign Affairs (2008) Kontseptsiya vneshnei politiki Rossiiskoi Federatsii [Foreign policy concept of the Russian Federation], (Moscow: Ministerstvo Inostrannykh Del (MID))

Ministry of Foreign Affairs (2013) Kontseptsiya vneshnei politiki Rossiiskoi Federatsii [Foreign policy concept of the Russian Federation], (Moscow: Ministerstvo Inostrannykh Del (MID))

Ministry of Industry and Trade (2003) Energeticheskaya strategiya Rossii na period do 2020 goda [Russia's Energy Strategy for the period to 2020] (Moscow: Ministerstvo promyshlennosti i torgovli)

Moshes, A. (2013) A Marriage of Unequals: Russian-Ukrainian Relations under Yanukovych (Berlin: Deutsche Gesellschaft für Auswärtige Politik e.V.)

Nekrasov, A.S. and Sinyak, Yu.V. (2001) "Problemy i perspektivy rossiiskoi energetiki na poroge XXI veka [Problems and perspectives for Russian energy on the threshold to the 21st century]", Problemy prognozirovaniya, 2001 (1): 86-101

Nurgaliyeva, L. (2016) "Kazakhstan's economic soft balancing policy vis-à-vis Russia: From the Eurasian Union to the economic cooperation with Turkey", Journal of Eurasian Studies, 7 (1): 92-105

Orttung, R.W. and Øverland, I. (2011) "A limited toolbox: Explaining the constraints on Russia's foreign energy policy", Journal of Eurasian Studies, 2 (1): 74-85

Pravda, A. (1996) "The public politics of foreign policy" in Malcolm, N. et al. eds., Internal Factors in Russian Foreign Policy (Oxford: Oxford University Press), pp.169-229

Putin, V. (1999) "Rossiya na rubezhe tysyacheletiya [Russia at the turn of the millennium]", Nezavisimaya gazeta, 30 December 1999, p.4

Putin, V. (2000) "Otkrytoe pis'mo Vladimira Putina k rossiiskim izbiratelyam [Vladimir Putin's open letter to Russian voters]", Kommersant, 25 February 2000, p.3

RFE/RL (2003) "RFE/RL Newsline", Radio Free Europe/Radio Liberty, 3 October

Rutland, P. (2008) "Russia as an energy superpower", New Political Economy, 13 (2): 203-210

Rutland, P. and Kazantsev, A. (2016) “The limits of Russia's 'soft power", Journal of Political Power, 9 (3): 395-413 
Samokhvalov, V. (2015) "Ukraine between Russia and the European Union: Triangle revisited", Europe-Asia Studies, 67 (9): 1371-1393

Smith, H. (2016) "Statecraft and post-imperial attractiveness: Eurasian integration and Russia as a Great Power", Problems of Post-Communism, 63 (3): 171-182

Socor, V. (2010) "Salient issues in Ukraine-Russia Relations and Yanukovych's Moscow Visit”, Eurasia Daily Monitor, 10 March

Solanko, L. (2016) Opening up or Closing the Door for Foreign Trade? Russia and China Compared. BOFIT Policy Brief. (Helsinki: Bank of Finland Institute for Economies in Transition)

Sovet po vneshnei i oboronnoi politike (SVOP) (1992) "Strategiya dlya Rossii [A Strategy for Russia]", Nezavisimaya gazeta, 19 August

Stegen, K.S. (2011) "Deconstructing the 'energy weapon': Russia's threat to Europe as a case study", Energy Policy, 39: 6505-6513

Stent, A.E. (2008) "An energy superpower? Russia and Europe" in Campbell, K. and Price, J. ed., The Global Politics of Energy (Washington, DC: Aspen Institute), pp.76-96

Suslov, D. (2003) "Rossiya ob"yavlyaet NATO kholodnuyu voinu [Russia declares a cold war on NATO]", Nezavisimaya gazeta, 10 October, p.5

Ter-Matevosian, V. et al. (2017) "Armenia in the Eurasian Economic Union: Reasons for joining and its consequences", Eurasian Geography and Economics, 58 (3): $340-360$

Wilson, J.L. (2010) "The legacy of the color revolutions for Russian politics and foreign policy", Problems of Post-Communism, 57 (2): 21-36

Anex, R.P. (2002) "Restructuring and privatizing electricity industries in the Commonwealth of Independent States", Energy Policy, 30 (5): 397-408

ARKA News Agency (2012a) "Pravitel'stvo Armenii odobrilo dosrochnoe prekrashchenie dogovora s 'INTER RAO EES' o doveritel'nom upravlenii AES [The government of Armenia approved early termination of the agreement on management of the NPP by 'Inter RAO UES']” [online]. 1 March (Yerevan: ARKA News Agency). Available from: http://arka.am/ru/news/business/pravitelstvo_armenii_odo brilo_dosrochnoe_prekrashchenie_dogovora_s_inter_rao_ees_o_doveritelnom_upra/ [Accessed 25 October 2018]

ARKA News Agency (2012b) "Glava Rosatoma ne schitaet neobkhodimym uchastie Rossii v upravlenii Armyanskoi AES [The head of Rosatom does not find it necessary for Russia to take part in the management of the Armenian NPP]" [online]. 7 February (Yerevan: ARKA News Agency). Available from: http://arka.am/ru/news/economy/gla va_rosatoma_ne_schitaet_neobkhodimym_uchastie_rossii_v_upravlenii_armyanskoy_ aes_/ [Accessed 25 October 2018]

ARKA News Agency (2015) "Deloitte \& Touche says the rise of electricity in Armenia is justified" [online]. 30 September (Yerevan: ARKA News Agency). Available from: http://arka.am/en/news/technology/deloitte_touche_says_rise_of_electricity_ in_armenia_is_justified/[Accessed 22 October 2018]

Avakyan, S. (2014) "Odisseya ZAO 'Elektricheskie seti Armenii' [The Odyssey of the private limited company 'Electric networks of Armenia']” [online]. 10 March (Yerevan: Hetq.am). Available from: https://hetq.am/ru/article/33072 [Accessed 22 October 2018]

Babich, D. (1997) "Boris Nemtsov razbiraetsya s RAO 'EES Rossii' [Boris Nemtsov investigates RAO EES of Russia]" Nezavisimaya gazeta, 9 April, p.1

Bekker, A. (1997) "Gosudarstvo reabilitiruet sebya v pravakh na RAO 'EES' [The state reinstates its entitlement to RAO EES]" Segodnya, 15 January 
Bekker, A. (2003) "V pol'zu RAO EES [To the benefit of RAO UES]" Vedomosti, 7 August

Berger, M. and Proskurnina, O. (2008) Krest Chubaisa [Chubais's Cross] (Moscow: KoLibri)

Blagov, S. (2006) "China eyes Russia, Central Asian states as source of cheap electricity" Eurasia Daily Monitor, 26 June

Bol'shakov, S. and Ishmukhammetov, F. (2007) "Kazakhstan prizval AES k rasplate [Kazakhstan calls on AES for payment]" Kommersant, 6 October, p.5

Bruce, C. and Yafimava, K. (2009) "Moldova's gas sector" in Pirani, S. ed., Russian and CIS Gas markets and their impact on Europe (Oxford: Oxford University Press for the Oxford Institute for Energy Studies), pp.170-202

Burlak, S. (2005) "Voina kak sposob otvlecheniya ot revolyutsii. Voiska i voennaya tekhnika styagivayutsya po obe storony Dnestra [War as a distraction from revolution. Troops and military equipment assemble on both sids of the Dnestr]" Nezavisimaya gazeta, 21 February, p.12

Butrin, D. and Rudenko, G. (2004) "Ukrainskikh energetikov sberegut ot rossiiskikh kolleg putem aresta imushchestva [Ukrainian energy business is protected from Russian colleagues through property confiscation]" Kommersant, 17 March, p.16

Butrin, D. et al. (2003) "Ukraina pozhertvovala vitse-prem'erom posle ego vystupleniya protiv rossiiskogo TEKa [Ukraine sacrifices the deputy prime minister after his statements on the Russian energy sector]" Kommersant, 8 December, p.13

Chubais, A. (2003) "Missiya Rossii v XXI veke [Russia's mission in the 21st century]" Nezavisimaya gazeta, 1 October, p.1

Civil.ge (2003) “AES sells Telasi to Russian UES” [online]. 1 August (Tbilisi: Civil.ge). Available from: https://old.civil.ge/eng/article.php?id=4685 [Accessed 25 October 2018]

Civil.ge (2004) "Ex-energy minister on trial" [online]. 3 November (Tbilisi: Civil.ge). Available from: https://old.civil.ge/eng/article.php?id=8249 [Accessed 25 October 2018]

Civil.ge (2009) "Russia, Georgia to jointly manage Enguri Power Plant" [online]. 12 January (Tbilisi: Civil.ge). Available from: http://old.civil.ge/eng/article.php?id= 20257 [Accessed 12 October 2018]

Civil.ge (2011) "EIB Lends Georgia EUR $20 \mathrm{mln}$ for Enguri HPP" [online]. 7 January (Tbilisi: Civil.ge). Available from: http://old.civil.ge/eng/article.php?id=23025 [Accessed 12 October 2018]

Crane, K., Peterson, D.J. and Oliker, O. (2005) "Russian Investment in the Commonwealth of Independent States", Eurasian Geography and Economics, 46 (6): 405-444

Datamonitor (2009) Electricity in Russia - October 2009. Industry Profile. (New York/ London/Frankfurt/Sydney: Datamonitor)

Decree No. 426 (28/04/1997) Ob osnovnykh polozheniyakh strukturnoi reformy v sferakh estestvennykh monopolii [On the basic provisions for structural reform in the spheres of the natural monopolies] (Moscow: President of the Russian Federation)

Decree No. 688 (21/05/2012) O vnesenii izmenenii v perechen' strategicheskikh predpriyatii i strategicheskikh aktsionernykh obshchestv, utverzhdennii Ukazom Prezidenta Rossiiskoi Federatsii ot 4 avgusta 2004 g. No. 1004 [On changes to the list of strategic enterprises and shareholding companies, established by Presidential Decree no. 1004 from 4 August 2004] (Moscow: President of the Russian Federation)

Decree No. 695 (22/05/2012) O merakh po privatizatsii nakhodyashchikhsya v federal'noi sobstvennosti paketov aktsii krupneishikh kompanii toplivno-energeticheskogo kompleksa [On measures for the privatisation of state-held stocks in the largest companies of the fuel and energy complex] (Moscow: President of the Russian Federation) 
Decree No. 721 (01/07/1992) Ob organizatsionnykh merakh po preobrazovaniyu gosudarstvennykh predpriyatii, dobrovol'nykh ob"edinenii gosudarstvennykh predpriyatii v aktsionernye obshchestva [On the organisational measures to convert state enterprises, voluntary associations of state enterprises into shareholding companies] (Moscow: President of the Russian Federation)

Decree No. 889 (25/07/1998) O merakh po snizheniyu tarifov na elektricheskuyu energiyu [On measures to reduce electricity tariffs] (Moscow: The President of the Russian Federation)

Decree No. 922 (14/08/1992) Ob osobennostyakh preobrazovaniya gosudarstvennykh predpriyatii, ob"edinenii, organizatsii toplivno-energeticheskogo kompleksa v aktsionernye obshchestva [On the specificities of the conversion of state enterprises, associations and organisations in the fuel and energy complex into shareholding companies] (Moscow: The President of the Russian Federation)

Decree No. 923 (15/08/1992) Ob organizatsii upravleniya elektroenergeticheskim kompleksom Rossiiskoi Federatsii v usloviyakh privatizatsii [On the organisation of management of the electricity complex of the Russian Federation during the privatisation process] (Moscow: President of the Russian Federation)

Decree No. 1009 (04/08/2004) Ob utverzhdenii perechnya strategicheskikh predpriyatii i strategicheskikh aktsionernykh obshchestv [On the approval of a list of strategic enterprises and strategic shareholding companies] (Moscow: President of the Russian Federation)

Decree No. 1285 (11/09/2012) O merakh po zashchite interesov Rossiiskoi Federatsii pri osushchestvlenii rossiiskimi yuridicheskimi litsami vneshneekonomicheskoi deyatel'nosti [On measures to protect the interests of the Russian Federation when foreign economic activity is carried out by a Russian juridical person] (Moscow: President of the Russian Federation)

Decree No. 1334 (05/11/1992) O realizatsii v elektroenergeticheskoi promyshlennosti Ukaza Prezidenta Rossiiskoi Federatsii ot 14 avgusta 1992 g. N 922 "Ob osobennostyakh preobrazovaniya gosudarstvennykh predpriyatii, ob"edinenii, organizatsii toplivno-energeticheskogo kompleksa v aktsionernye obshchestva" [On the realisation of Decree no. 922, issued on 14 August 1992 by the President of the Russian Federation "On the specificities of the conversion of state enterprises, associations and organisations in the fuel and energy complex into shareholding companies" in the electricity industry] (Moscow: President of the Russian Federation)

Derbilova, E. and Panyushkin, V. (2007) “'Khochu na pensiiu' - Anatolii Chubais, predsedatel' pravleniya RAO 'EES Rossii' ['I would like to retire' - Anatolii Chubais, head of management at RAO UES of Russia]" Vedomosti, 4 October

Derbilova, E., Tsukanov, I. and Pis'mennaya, E. (2012) "Ne vozvrashchaites' k bylym vozlyublennym' - Anatolii Chubais, predpravleniya 'Rusnano', eks-predpravleniya RAO 'EES Rossii' ['Don't return to old sweethearts', says Anatolii Chubais, CEO of Rusnano and former CEO of RAO UES]" Vedomosti, 15 November, p.5

Dokukina, K. (2012) "“Rezervov dlya rosta tsen uzhe net” - Aleksandr Starchenko, predsedatel' nablyudatel'nogo soveta "Soobshchestva pokupatelei rynkov elektronenergii" ['There are no longer reserves for price increases', says Aleksandr Starchenko, head of the Association of Buyers in Electricity Markets' Monitoring Council]" Vedomosti, 13 August

Dzaguto, V. (2009a) “Igor' Sechin vzyskal dolg s Tadzhikistana [Igor Sechin recovers debt from Tajikistan]" Kommersant, 27 April, p.11 
Dzaguto, V. (2009b) "Tadzhikistan vklyuchil Ural v elektricheskuyu skhemu [Tajikistan includes the Urals in its electricity schedule]" Kommersant, 7 April, p.11

Dzaguto, V. (2010a) “"Inter RAO” pogloshchaet gosudarstevennye aktivy [Inter RAO swallows state equity]" Kommersant, 1 October, p.9

Dzaguto, V. (2010b) "Rossiya tyanet seti k Pakistanu [Russia draws lines to Pakistan]" Kommersant, 19 August, p.9

Dzaguto, V. (2010c) “'Inter RAO’ vozvrashchaetsya na Blizhnyi Vostok [Inter RAO returns to the Middle East]" Kommersant, 2 June, p.11

Dzaguto, V. (2011) "Rossiya tyanet LEP na sebya [Russia draws a power line for itself]" Kommersant, 24 January, p.9

Dzaguto, V. (2016) "Pravila igry v suverennye fondy Rossii menyayutsya [The rules of the game of Russia's sovereign wealth funds are changing]" Kommersant, 27 December, p.7

Dzaguto, V. and Grishkovets, E. (2011) “'Inter RAO' otkazalos' ot malogo [Inter RAO denies itself little]" Kommersant, 13 May, p.12

Dzaguto, V. and Skorlygina, N. (2013) "Den'gi 'Inter RAO' otpravyat v Kirgiziyu [Inter RAO's money will be sent to Kyrgyzstan]" Kommersant, 18 February, p.11

Dzaguto, V. and Dyatel, T. (2017) "'Rusgidro' slivaetsya iz armyanskikh GES [Rushydro flows away from Armenian hydropower plants]" Kommersant, 23 April, p.11

Dzaguto, V., Netreba, P. and Zanina, A. (2012) "Igoryu Sechinu otklyuchayut elektrichestvo [Electricity is turned off for Igor Sechin]" Kommersant, 21 September, p.1

Dzaguto, V., Fomicheva, A. and Mel'nikov, K. (2013) "Igor' Sechin nachal sborku 'Inter RAO' [Igor Sechin begins to assemble Inter RAO]” Kommersant, 6 December, p. 11

Dzyadko, T. (2013) "Sechin vozvrashzhetsya v energetiku [Sechin return to electricity]" Vedomosti, 13 May

Dzyadko, T. and Ivankina, E. (2014) 'Sechin blokiruet 'Inter RAO' [Sechin blocks Inter RAO]" RBK Daily, 20 January, p.1

Egorova, T. (2005) 'Interv'yu: Anatolii Chubais, predsedatel' pravleniya RAO 'EES Rossii': 'Gosudarstvo - plokhoi sobstvennik' [Interview: Anatolii Chubais, chairman of RAO UES's management: 'The state is a poor owner']" Vedomosti, 22 November

Egorova, T. (2006a) 'Interv'yu: Andrei Rappoport, predsedatel' pravleniya Federal'noi setevoi kompanii [Interview. Andrei Rappoport, general manager of the Federal Grid Company]" Vedomosti, 14 February

Egorova, T. (2006b) "Rubil'nik dlya 'Gazproma' [A knife switch for Gazprom]" Vedomosti, 14 February

Egorova, T. and Gavrish, O. (2003) "Kuchma ispugalsya RAO UES [Kuchma scared of RAO UES]" Vedomosti, 22 December

Egorova, T., Gavrish, O. and Nikol'skii, A. (2003) "RAO idet po provodam [RAO follows the power lines]" Vedomosti, 5 December

Ekonomika i zhizn' (1996) “Zerkalo [Mirror]” Ekonomika i zhizn', 24 August

Elektricheskie seti Armenii (2013) Godovoi otchet 2012 [Annual report 2012]. (Yerevan: ENA/Electric Networks of Armenia)

Embassy Chisinau (2007) Moldovan energy woes, 07CHISINAU1520/Wikileaks \#135844. Issue date 28 December 2007. Cablegate [online]. (Published by Wikileaks 1 September 2011). Available from: https://search.wikileaks.org/plusd/cables/07CHI SINAU1520_a.html [Accessed 30 June 2019] 
Embassy Chisinau (2008) Russian energy giant completes takeover of Moldovan Power Plant In Transnistria, 08CHISINAU846/Wikileaks \#166724. Issue date 20 August 2008. Cablegate [online]. (Published by Wikileaks 1 September 2011). Available from: https://search.wikileaks.org/plusd/cables/08CHISINAU846_a.html [Accessed 30 June 2019]

Engoian, A. (2006) "Industrial and institutional restructuring of the Russian electricity sector: Status and issues" Energy Policy, 34 (17): 3233-3244

Fadeeva, A. (2018) "Dolgie provoda [Long lines]" RBK Daily, 4 July, p.12

Fadeeva, A. and Serkov, D. (2018) "Popalas' na donbasskikh setyakh [Caught on the Donbass grids]" RBK Daily, 25 June, pp.1, 3

Fankhauser, S. and Tepic, S. (2007) "Can poor consumers pay for energy and water? An affordability analysis for transition countries" Energy Policy, 35 (2): 1038-1049

Federal Law No. 35 (26/03/2003) Ob elektroenergetike [On electricity] (Moscow: The Federal Assembly)

Federal Law No. 36 (26/03/2003) Ob osobennostyakh funktsionirovaniya elektroenergetiki $v$ perekhodnyi period $i$ o vnesenii izmenenii v nekotorye zakonodatel'nye akty Rossiiskoi Federatsii i priznanii utrativshimi silu nekotorykh zakonodatel'nykh aktov Rossiiskoi Federatsii v svyazi s prinyatiem Federal'nogo zakona 'Ob elektroenergetike'” [On the specificities of the functioning of the electricity system in the transition period and on the entering of alterations in some legislative acts of the Russian Federation and the declaration as invalid of some legislative acts of the Russian Federation in connection with the passing of the Federal law 'On electricity'] (Moscow: The Federal Assembly)

Fialko, A., Mazneva, E. and Chechel', A. (2010) "Koval'chuk sobiraet aktivy [Kovalchuk gathers assets]" Vedomosti, 26 May

FSK (Federal'naya Setevaya Kompaniya) (2018) "Istoriya otrasli [The history of the sector]" [online]. (Moscow: Federal'naya setevaya kompaniya). Available from: http://www.fsk-ees.ru/about/history_industry/ [Accessed 10 October 2018]

Gabuev, A. (2009) 'Predvaritel'naya nedogoverennost' [A preliminary lack of agreement]" Kommersant, 25 February, p.8

Gabuev, A. and Konstantinov, A. (2011) "Poka idet zaderzhka v otnosheniyakh, mesto zanimayut drugie [While [our] relations are held up, others take [our] place]" Kommersant, 4 August, p.6

Gabuev, A. and Karabekov, K. (2011) "Otnosheniya s Kirgiziei postavleny na zhidkuyu osnovu [Relations with Kyrgyzstan on a liquid basis]" Kommersant, 18 November, p. 8

Gaddy, C.G. and Ickes, B.W. (2002) Russia's Virtual Economy (Washington, DC: Brookings Institution Press)

Gaidar, E. and Chubais, A. (2008) Ekonomicheskie zapiski [Notes on the economy] (Moscow: Rossiiskaya politicheskaya entsiklopediya ROSSPEN)

Gamova, S. (2004) "Pereuchet [Stocktaking]" Novye izvestiya, 18 October, p.1

Gamova, S. (2007) "Obmenyali Pasata na kilovatty [Pasat exchanged for kilowatts]" Nezavisimaya gazeta, 18 July 2007, p.1

Gamova, S. and Krashakov, A. (2006) "Kompromissnyi kilovatt. Moldaviya gotova ustupit' "Gazpromu" elektroseti v obmen na deshevyi gaz [Kilowatt compromise. Moldova ready to give up its power grid to Gazprom in return for cheap gas]" Nezavisimaya gazeta, 5 April, p.3

Gazeta (2003) "Chubais predlozhil Voloshinu postoyannuyu rabotu [Chubais offered Voloshin a regular job]" Gazeta, 31 October, p.2

Georgian Industrial Group (2016) "International company, affiliated with the Georgian Industrial Group, as a part of international investors consortium has acquired shares 
in the holding company of energy company 'Mtkvari'" [online]. 2 June (Tbilisi: Georgian Industrial Group). Available from: http://www.gig.ge/?newsid=17 [Accessed 12 October 2018]

Gleason, G. (2004) "Russian companies propose debt-equity swaps in Central Asia" Eurasia Daily Monitor, 11 October

Glumskov, D. and Grib, N. (2004) "Tadzhikistan ne rastratil energiyu vpustuyu [Tajikistan did not spend its energy unnecessarily]" Kommersant, 18 October, p.13

Gordienko, A. and Orlova, N. (2005) "Kocharyan izmenyaet Rossii. Chast' svoego otpuska neprimirimyi borets s Kremlem Mikhail Sakashvili provedet na Sevane v kompanii armyanskogo prezidenta [Kocharyan betrays Russia. The uncompromising campaigner against the Kremlin, Mikhail Saakashvili, will spend part of his holiday on the Sevan in the company of the Armenian president]" Nezavisimaya gazeta, 19 August, p.1

Gorelov, N. (2001) "MAP interesuetsya provodami. Atomshchiki prodolzhayut sporit' s RAO 'EES Rossii' [MAP is interested in grids. The nuclear business continues its conflict with RAO UES]" Vremya novostei, 22 August, p.5

Gorelov, N. (2003) "Energeticheskii kart-blansh [Carte blanche in energy]" Vremya novostei, 15 January, p.1

Gorelov, N. (2004) "Elektrichestvo v obmen na vodu. RAO 'EES' zhelaet postroit' elektrostantsii v Kirgizii [Electricity in return for water. RAO UES wants to build power stations in Kyrgyzstan]" Vremya novostei, 23 August, p.8

Gorelov, N. (2006) "Eksportno-importnoe napryazhenie [Export-import tension]" Vremya novostei, 19 December, p.8

Gorelov, N. (2007a) "Moldavskii transit [Moldavian transit]" Vremya novostei, 16 July, p.8

Gorelov, N. (2007b) "Premiya s chetvertoi popytki [Bonus at fourth attempt]" Vremya novostei, 25 June, p.8

Gorelov, N. (2008a) "Pro eksport zabyli [They forgot about export]" Vremya novostei, 3 July, p.7

Gorelov, N. (2008b) "Elektricheskoe bratstvo [Electric brotherhood]" Vremya novostei, 5 March, p. 8

Gorelov, N. (2008c) "Tadzhikskie nepriyatnosti [Tajik troubles]" Vremya novostei, 21 January, p. 8

Gotova, N. (1997) “Anatolii D’yakov, kazhetsya, smirilsya s MVF [Anatolii D’yakov is apperently reconciled with IMF]" Segodnya, 9 April

Gotova, N. (2003) "Gruzinskii pokhod Chubaisa [Chubais's Georgian campaign]" Profil', 11 August, pp.28-29

Granik, I. (2010) "Rossiya i Kazakhstan zaklyuchili atomnye soglasheniya [Russia and Kazakhstan conclude nuclear agreements]" Kommersant, 6 July

Gray, D. (1995) Reforming the energy sector in transition economies. World Bank Discussion Papers. 296. (Washington, DC: The World Bank)

Grib, N. (2003) "Belorusskie energetiki perekinuli most v Evropu [The Belarussian power sector throw out a bridge to Europe]" Kommersant, 4 February, p. 15

Grib, N. (2004) “"Belenergo' torgovalsya nedolgo [Belenergo did not bargain for long]" Kommersant, 13 April, p.16

Grib, N. and Dar'in, A. (2006) "Moldaviyu rasschitali po-evropeiski [Moldova given a European bill]" Kommersant, 29 May, p.14

Grib, N. and Kornysheva, A. (2006) “'Inter RAO EES' gotova pereimenovat'sya v 'Gazpromenergo' [Inter RAO ready to change name to Gazpromenergo]" Kommersant, 29 June, p.14 
Grib, N., Grishkovets, E. and Gavrish, O. (2006) “'Inter RAO EES' kupit elektroenergiyu na Ukraine v obmen na turkmenskii gaz [Inter RAO buys electricity in Ukraine in return for Turkmen gas]" Kommersant, 2 October, p.17

Grigoryan, A. (2015a) "Sale of Armenia's monopoly electricity distributor confirmed" Eurasia Daily Monitor, 14 October

Grigoryan, A. (2015b) "Planned electricity fee increase may revive protest movement in Armenia" Eurasia Daily Monitor, 12 June

Grigoryan, A. (2015c) "Yerevan electricity protests reach Climax" Eurasia Daily Monitor, 29 June

Grigoryan, A. (2016a) "Armenia, Georgia, Russia and Iran plan to expand energy cooperation" Eurasia Daily Monitor, 4 January

Grigoryan, A. (2016b) "Russian factor remains critical for Armenia's regional projects" Eurasia Daily Monitor, 1 March

Grishkovets, E. (2008a) "Pravila igry [The rules of the game]" Kommersant, 30 April, p.13

Grishkovets, E. (2008b) “'Inter RAO' gotovo torgovat'sya [Inter RAO is ready to trade]" Kommersant, 7 May, p.9

Grishkovets, E. (2008c) “"Inter RAO’ voshlo v Moldavskuyu GRES dvazhdy [Inter RAO entered Moldova GRES twice]" Kommersant, 31 July 2008, p.10

Grishkovets, E. (2009) "Moi vnutrennii golos davno uzhe ne obmanyvaet menya" [My inner voice has not failed me for a long time]" Kommersant, 26 June, p.1

Grishkovets, E. (2010a) "Pravila igry pereklyuchaet rukovoditel' gruppy TEK Ekaterina Grishkovets [The rules of the game as interpreted by the head of the Fuel and Energy Group Ekaterina Grishkovets]" Kommersant, 12 January, p.7

Grishkovets, E. (2010b) "Ne bylo takogo, chtoby nas ne slyshali [It hasn't happened that we weren't heard]" Kommersant, 21 December, p.13

Grishkovets, E. (2011) "Dmitrii Medvedev vklyuchil svet Belorussii [Dmitrii Medvedev turns the light on for Belarus]" Kommersant, 4 July, p.5

Grishkovets, E. and Gavrish, O. (2006) “'Inter RAO EES' vyshlo na Ukrainu [Inter RAO goes to Ukraine]" Kommersant, 21 August, p.6

Grishkovets, E. and Dar'in, A. (2006) "Moldaviya oboidetsya bez rossiiskoi energii [Moldova makes do without Russian electricity]" Kommersant, 7 June, p.15

Grishkovets, E. and Ravinskii, V. (2008) “'Inter RAO EES' podryadilas' na stroiku Rogunskoi GES [Inter RAO contracts to the building of Rogun hydropower plant]" Kommersant, 2 July, p.10

Grishkovets, E. and Solov'ev, V. (2008) "Rossiya vozvrashchaetsya na Rogunskuyu GES [Russia returns to Rogun hydropower plant]" Kommersant, 6 June, p.14

Grishkovets, E. and Dzaguto, V. (2009) 'Glava 'RusGidro' pomozhet 'Inter RAO' potratit' \$2 mlrd [The head of RusHydro helps Inter RAO to spend \$2 bn]" Kommersant, 24 November, p.9

Grishkovets, E., Dzaguto, V. and Popov, V. (2008a) “'Inter RAO' vernulo moldavskii rynok [Inter RAO recovers the Moldavian market]" Kommersant, 24 December, p.17

Grishkovets, E., Dzaguto, V. and Solov'ev, V. (2009) “'Inter RAO' voidet v gruzinskie vody [Inter RAO enters Georgian waters]" Kommersant, 13 January, p.11

Grishkovets, E. et al. (2008b) "Igor' Sechin pribavil v moshchnosti [Igor Sechin puts on power]" Kommersant, 6 October, p.1

Gubenko, O. (2002) "Svet - na prodazhu. RAO 'EES Rossii' sostavilo eksportnye plany [Light for sale. RAO UES assembles export plans]" Izvestiya, 28 December, p.5 
Gudim, A. et al. (2003) Research paper on Transnistria (Chisinau: Center for Strategic Studies and Reforms)

Gularidze, T. (2003a) "Georgian authorities, UES Chief pledge for cooperation" [online]. 7 August (Tbilisi: Civil.ge). Available from: http://old.civil.ge/eng/article. php?id=4724 [Accessed 9 October 2018]

Gularidze, T. (2003b) "Tbilisi would have electricity, for the time being..." [online]. 11 February (Tbilisi: Civil.ge). Available from: https://old.civil.ge/eng/article.php?id= 3167 [Accessed 25 October 2018]

Gularidze, T. (2003c) "AES, Georgian government locked in battle" [online]. 28 February (Tbilisi: Civil.ge). Available from: https://old.civil.ge/eng/article.php?id=3264 [Accessed 25 October 2018]

Gustafson, T. (2012) Wheel of Fortune. The battle for oil and power in Russia (Cambridge, MA/London: The Belknap Press of Harvard University Press)

Hakobyan, A. (2003) “Armenia's light and protection?" Transitions Online, 7 November

Hashimova, U. (2017) "Uzbekistan and Kyrgyzstan undertake resolving their water disputes" Eurasia Daily Monitor, 17 October

IEA (2003) Regulatory reform review of Russia: Background on the electricity sector (Paris: International Energy Agency)

Inter RAO (2006) Godovoi otchet 2005 [Annual report 2005] (Moscow: Inter RAO)

Inter RAO (2009a) Godovoi otchet 2008 [Annual report 2008] (Moscow: Inter RAO)

Inter RAO (2009b) 'Sobranie aktsionerov OAO 'Inter RAO EES' rassmotrit vopros provedeniya dopemissii v pol'zu Vneshekonombanka, FAUGI $i$ GK 'Rosatom' [Inter $R A O$ 's shareholder meeting will consider the question of an additional share issuing in favour of Vneshekonombank, FAUGI and Rosatom State Corporation]" [online]. 1 June 2009 (Moscow: Inter RAO). Available from: http://www.interrao.ru/press-cen ter/news/?ELEMENT_ID=659 [Accessed 29 November 2011]

Inter RAO (2010a) "Import elektroenergii [Electricity import]" [online]. n.d. (Moscow: Inter RAO). Available from: http://www.interrao.ru/activity/traiding/exporteng/ [Accessed 12 January 2010]

Inter RAO (2010b) Godovoi otchet 2009 [Annual report 2009] (Moscow: Inter RAO)

Inter RAO (2011a) "Struktura aktsionernogo kapitala [Capital structure]" [online]. n. d. (Moscow: Inter RAO). Available from: http://www.interrao.ru/company/capital/ [Accessed 28 November 2011]

Inter RAO (2011b) Godovoi otchet OAO “Inter RAO EES” za 2010 god [Annual report for Inter RAO UES in 2010] (Moscow: Inter RAO)

Inter RAO (2011c) "INTER RAO UES and RusHydro close Sevan-Razdan cascade sale in Armenia" [online]. 24 March (Moscow: Inter RAO). Available from: http://www. interrao.ru/en/press-center/news/detail.php?ID=441 [Accessed 22 October 2018]

Inter RAO (2011d) "INTER RAO UES Board of Directors approves corporate development Strategy till 2015 with an outlook till 2020" [online]. 20 January (Moscow: Inter RAO). Available from: http://www.interrao.ru/en/press-center/news/ detail.php?ID=387 [Accessed 22 October 2018]

Inter RAO (2011e) "Inter RAO establishes representative office in the Middle East" [online]. 13 February (Moscow: Inter RAO). Available from: http://www.interrao.ru/ en/press-center/news/detail.php?ID=385 [Accessed 15 October 2018]

Inter RAO (2014) Godovoi otchet OAO “Inter RAO EES” za 2013 god [Annual report for Inter RAO UES in 2013] (Moscow: Inter RAO) 
Inter RAO (2015) Godovoi otchet OAO “Inter RAO EES” za 2014 god [Annual report for Inter RAO UES in 2014] (Moscow: Inter RAO)

Inter RAO (2018a) “Strategiya razvitiya Gruppy 'Inter RAO' na period do 2020 g. [Inter RAO Group's development strategy to 2020]" [online]. (Moscow: Inter RAO). Available from: http://www.interrao.ru/strategy/ [Accessed 22 October 2018]

Inter RAO (2018b) Inter RAO EES. 2017. Godovoi otchet [Inter RAO UES. 2017. Annual report] (Moscow: Inter RAO)

Inter RAO (2018c) "Zarubezhnyi biznes [Foreign business]" [online]. (Moscow: Inter RAO). Available from: http://www.interrao.ru/activity/foreignact/ [Accessed 15 October 2018]

Ispolatov, S. (2010a) "Vpered v proshloe [Forward to the past]" $R B C$ Daily, 26 May

Ispolatov, S. (2010b) “Inter RAO' zaberet ne vse [Inter RAO does not get it all]" $R B C$ Daily, 11 August

Ivanov, N. (1998) “Boris Brevnov i Anatolii D'yakov - kvity [Boris Brevnov and Anatolii D'yakov are quits]" Segodnya, 30 January

Ivzhenko, T. (2005) “Kiev boitsya prodeshevit'. Rossiiskie oligarkhi nachali bor'bu za ukrainskuyu energetiku [Kyiv is afraid of selling too cheap. Russian oligarchs have started their fight for Ukrainian electricity]" Nezavisimaya gazeta, 27 April, p.3

Kaiser, M.J. (2000) "Pareto-optimal electricity tariff rates in the Republic of Armenia" Energy Economics, 22 (4): 463-495

Khrennikov, I. (2006) "Imperiya na vydan'e [A marriageable empire]" Forbes, 3 January

Kiselev, V. and Panfilova, V. (2005) "Konets sveta v otdel'noi vzyatoi strane. Rossiiskie energetiki ne soshlis' s moldavskimi kollegami $\mathrm{v}$ tsene [The end of light in a single country. The Russian energy people did not agree about a price with their Moldovan colleagues]" Nezavisimaya gazeta, 11 November, p.5

Kjærnet, H. (2007) "En smak av egen medisin: Aserbajdsjans russlandsstrategi [A taste of its own medicine: Azerbaijan's Russia strategy]", Nordisk Øst-Forum, 21 (4): 457-474

Klasson, M. (2000) "Energeticheskaya tyaga [The thrust of energy]" Vremya MN, 25 October, p.4

Klasson, M. (2001) "Chubais vvodit za Uralom osoboe polozhenie [Chubais introduces a state of emergency on the other side of the Urals]" Vremya MN, 8 February, p.3

Klasson, M. (2003) "Chubais podnimaet energetiku Gruzii [Chubais raises Georgia's energy]" Vremya $M N, 7$ August, p.1

Knyazev, V. and Reznik, I. (2000) "Tyumenskaya oblast'. Poltora milliarda pod zemlei [Tymen' oblast'. One and a half billion under the turf]" Kommersant-Vlast, 5 December, p.59

Kolesnikov, A. (2008) Anatolii Chubais. Biografiya [Anatolii Chubais. A biography] (Moscow: AST)

Kommersant-Vlast' (2005) "Fevral' bez revolyutsii [February without revolution]" Kommersant-Vlast', 31 January

Kommersant (1994) "Press-konferentsiya RAO [RAO's press conference]" Kommersant, 16 December

Kommersant (2008) "Aleksandr Voloshin pokinul energetiku [Aleksandr Voloshin leaves energy]" Kommersant, 6 October

Kommersant (2009) "Plany 'Inter RAO' [Inter RAO's plans]" Kommersant, 26 June

Kornysheva, A. (2003) "Prezident prinyal otchet Anatoliya Chubaisa o zime [The president received Anatolii Chubais's winter report]" Kommersant, 8 December, p. 2

Kravchenko, E. (2003) “"Mirnyi atom'v rukakh Chubaisa. Armyanskuyu AES peredayut v upravlenie rossiiskomu energokholdingu ['The peaceful atom' in Chubais's 
hands. The Armenian nuclear power plant is being transferred to the Russian power holding's management]" Izvestiya, 8 July, p.5

Kurronen, S. (2006) "Russian electricity sector - reform and prospects", BOFIT Online, 2006 (6). Available from: https://helda.helsinki.fi/bof/bitstream/handle/123456789/ 12518/128145.pdf [Accessed 5 April 2020]

Latukhina, K. (2007) "Chubais dal otvet Putinu [Chubais replies to Putin]" Vedomosti, 18 December

Levinskii, R. (2005) 'RAO EES i 'Gazprom' snova vmeste [RAO UES and Gazprom back together]" Vedomosti, 6 April

Libman, A. and Kheifets, B.A. (2007) "Korporativnaya model' regional'noi ekonomicheskoi integratsii [The corporate model of regional economic integration]", Mirovaya ekonomika i mezhdunarodnye otnosheniya, 2007 (3): 15-22

Litvinov, A. (2004) "Alyuminievye sapogi [Aluminium boots]" Gazeta, 18 October, p.2

Maksimov, V. (2001) "RAO EES sdaet eksport [RAO UES hands over export]" Vedomosti, 31 October

Marat, E. (2008a) "Need for more transparency in Kyrgyz and Tajik energy sectors to avoid future crises" Eurasia Daily Monitor, 19 December

Marat, E. (2008b) "Tajik government asks for contributions to build Rogun hydropower station" Eurasia Daily Monitor, 1 May

Marat, E. (2010) "Will Tajikistan successfully construct Rogun?" Eurasia Daily Monitor, 26 January

Mazaeva, O. (2004) "Kuplyu elektroenergiyu bez posrednikov. Minsk ishchet al'ternativnykh postavshchikov $\mathrm{v}$ obkhod Moskvy [I will buy electricity without intermediaries. Minsk is looking for alternative suppliers to Moscow]" Nezavisimaya gazeta, 18 February, p.5

Mazneva, E. (2008) "Glavnyi po setyam [The head of the grids]" Vedomosti, 2 December

Mazneva, E. (2010) "Doroga v Kazakhstan [The road to Kazakhstan]" Vedomosti, 3 March

Medvedeva, E. (2006) “'Inter RAO' vne zakona [Inter RAO outside the law]” Vedomosti, 19 December

Medvedeva, E. (2007a) “'U nas nastoyashchaya tekhnicheskogo revolyutsiya' - Andrei Rappoport, predsedatel' pravleniya Federal'noi setevoi kompanii ['We are undergoing a genuine technological revolution' - Andrei Rappoport, management chair at the Federal Grid Company]" Vedomosti, 27 December

Medvedeva, E. (2007b) “'Dochka' na vyrost [A 'daughter' to bring up]” Vedomosti, 17 January

Mel'nikov, K. (2012) "Gosudarstvo rasprodast TEK sebe [The state will sell the fuel and energy complex to itself]" Kommersant, 25 May, p.1

Melkumyan, S. (2002) "Ottok energii [Energy exodus]" Novye izvestiya, 1 August, p.4

Mirkadyrov, R. and Gordienko, A. (2004) "Predprodazhnyi vzryv. Nakanune vizita Chubaisa v Baku Azerbaidzhan okazalsya na grani energeticheskogo krizisa [A presell burst. Before Chubais's visit to Baku, Azerbaijan finds itself on the border of a power crisis]" Nezavisimaya gazeta, 25 May, p.1

Mishneva, R., Grib, N. and Butrin, D. (2004) "EES Rossii' ne nashlos' mesta na Ukraine [No room for Russia's UES in Ukraine]" Kommersant, 29 January, p.13

Movsesyan, G. (2005) 'S Chubaisom na vek. RAO 'EES' budet upravlyat' armyanskimi energosetyami 99 let [With Chubais for a century. RAO UES will manage the Armenian electricity grid for 99 years]" Vremya novostei, 25 July, p.7 
Murtazaev, E. (1995) "Dolgi energetikam rastut so skorost'yu 700 mln dollarov v mesyats [Electricity debts rise by 700 million dollars a month]" Segodnya, 20 December

Museum for the History of the Northwest Power Industry (2014) "D'yakov Anatolii Fedorovich" [online]. Muzei istorii energetiki severo-zapada (OAO TGK-1). Available from: http://energomuseum.ru/persons/dyakov_anatoliy_fyedorovich_/ [Accessed 26 September 2014]

Museum of the Urals Power Industry (2018) “Tsentral'noe dispetcherskoe upravlenie EES SSSR [The central control authority of the United Power System of the USSR]" [online]. Muzei energetiki Urala. Available from: http://musen.ru/chronicle/ 1969/ [Accessed 9 October 2018]

Naumova, A. and Grivach, A. (2004) "Opasnyi tranzit. Eksport gaza cherez Belorussiyu vyshel na pik riska [Dangerous transit. Gas export through Belarus reaches highest risk]" Vremya novostei, 18 February, p.7

Nevezhin, Yu. (1996) “Obrashchenie energetikov k pravitel'stvu [The electricity sector employees' address to the government]" Izvestiya, 20 December

Nevezhin, Yu. (1997) "Chto budet s RAO EES? [What will become of RAO EES?]" Izvestiya, 10 April

Newbery, D.M. (1994) "Restructuring and privatizing electric utilities in Eastern Europe", Economics of Transition, 2 (3): 291-316

OAO Inter RAO (OAO Sochinskaya GES) (2008) Godovoi otchet 2007 [Annual Report 2007] (Sochi: Inter RAO)

OECD/IEA (2005) Russian electricity reform. Emerging challenges and opportunities. (Paris: The Organisation for Economic Co-operation/the International Energy Agency)

Oganesyan, L. (2009) "Elektroenergiya - eto i valyuta, i politicheskie dividendy [Electricity is hard currency as well as political dividends]" Golos Armenii, 10 November

Oilcapital.ru (2012) "Reiting vliyaniya krupnykh predprinimatelei i top-menedzherov toplivno-energeticheskogo kompleksa $v$ dekabre $2012 \mathrm{~g}$. [Rating of the influence of major businessmen and top managers in the fuel and energy complex, December 2012]" [online]. 6 December (Moscow: IG Industriya). Available from: https://oilcapital.ru/news/compa nies/06-12-2012/reyting-vliyaniya-krupnyh-predprinimateley-i-top-menedzherov-tek-vdekabre-2012-g [Accessed 18 March 2019]

Oilcapital.ru (2016) "Reiting vliyaniya krupnykh predprinimatelei i top-menedzherov toplivno-energeticheskogo kompleksa v marte $2016 \mathrm{~g}$. [Rating of the influence of major businessmen and top managers in the fuel and energy complex, March 2016]" [online]. 29 March (Moscow: IG Industriya). Available from: https:/oilcapital.ru/news/companies/ 29-03-2016/reyting-vliyaniya-krupnyh-predprinimateley-i-top-menedzherov-toplivno-ene rgeticheskogo-kompleksa-v-marte-2016-g [Accessed 20 February 2019]

Orozobekova, C. (2016) "Kyrgyzstan's capacity to meet its CASA-1000 obligations comes under question" Eurasia Daily Monitor, 26 May

Panchenkova, M. and Starinskaya, G. (2016) "Nevedomoe bogatstvo [Unknown riches]" Vedomosti, 25 October, pp.1, 12

Panfilova, V. (2008a) "Privatizatsiya po-kirgizski [Privatisation Kyrgyz style]" Nezavisimaya gazeta, 4 February, p.17

Panfilova, V. (2008b) "Moskva sdelala predlozhenie Dushanbe [Russia gave Dushanbe an offer]" Nezavisimaya gazeta, 28 November, p.5

Panfilova, V. (2009) "Dushanbe pred'yavit Moskve schet [Dushanbe gives Russia the bill]" Nezavisimaya gazeta, 20 February, p.1 
Panfilova, V. (2011) "Predvybornyi triuk Bishkeka [Bishkek's pre-election trick]" Nezavisimaya gazeta, 12 April, p.6

Patel, S. (2013) "The Russian Power Revolution" Power, 157 (1): $44-49$

Peretolchina, A. (2008) "Po puti v Rumyniyu [On the road to Romania]" Vedomosti, 31 July

Peretolchina, A. and Derbilova, E. (2011) "Prigovor reforme [A sentence for reform]" Vedomosti, 18 March, p.1

Petlevoi, V., Derbilova, E. and Peschinskii, I. (2015) "Igor' Sechin - eto moi starshii tovarishch [Igor Sechin is my older friend]" Vedomosti, 4 July, p.12

Podobedova, L. and Milyukova, Ya. (2016) "Investitsii vmesto dividendov [Investment instead of dividends]" RBK Daily, 15 April, p.16

Polyakova, A. (2010) "Baku i Tbilisi khotyat soedinit' Vostok s Zapadom [Baku and Tbilisi want to unite East and West]" Georgia Times, 26 July

Polyanskii, N. (2001) "Svet i teni energosistemy Armenii. Pochemu vlasti respubliki otvergayut vygodnye predlozheniya rossiiskoi storony [The light and shadows of Armenia's energy system. Why the republic's authorities reject the Russian side's profitable offers]" Nezavisimaya gazeta, 7 April, p.5

Popşoi, M. (2016) "Are Moldovan consumers financing Transnistrian separatism?" Eurasia Daily Monitor, 21 April

Popşoi, M. (2017) "Moldova-Ukraine energy deal upsets Russia by cutting Transnistria out" Eurasia Daily Monitor, 3 April

Prikhodko, N. (2000) "Elektroenergiya kak energiya mirotvorchestva. Kishinev i Tiraspol' sposobny sovmestno reshat' ekenomicheskie voprosy [Electricity as peacemaking power. Chisinau and Tiraspol can decide on economic issues together]" Nezavisimaya gazeta, 19 December, p.5

Pulina, N. (2000) "Astana i Moskva dogovorilis' [Astana and Moscow have made a deal]" Nezavisimaya gazeta, 20 January

RAO UES (1997) Godovoi otchet OAO RAO EES 1996 [RAO UES Annual Report 1996] [electronic version] (Moscow: RAO UES)

RAO UES (1998) Godovoi otchet OAO RAO EES 1997 [RAO UES Annual Report 1997 ] [electronic version] (Moscow: RAO UES)

RAO UES (1999) Godovoi otchet OAO RAO EES 1998 [RAO EES Annual Report 1998 ] [electronic version] (Moscow: RAO UES)

RAO UES (2000) Godovoi otchet OAO RAO EES 1999 [RAO UES Annual Report 1999] [electronic version] (Moscow: RAO UES)

RAO UES (2001) Godovoi otchet OAO RAO EES 2000 [RAO UES Annual Report 2000] [electronic version] (Moscow: RAO UES)

RAO UES (2003) Godovoi otchet OAO RAO EES 2002 [RAO UES Annual Report 2002] (Moscow: RAO UES)

Recknagel, C. (2013) "Promises, promises: Moscow's record of broken aid pledges" [online]. 17 December (Prague: Radio Free Europe/Radio Liberty). Available from: https://www.rferl.org/a/russia-promises-aid-unfilled/25203488.html [Accessed 15 October 2018]

Reznik, I. and Egorova, T. (2006) “'Gazprom' vmesto RAO EES [Gazprom instead of RAO UES]" Vedomosti, 10 April

RFE/RL (2006) "RFE/RL Newsline" 26 January

Rosneftegaz (2014) Godovoi otchet otkrytogo aktsionernogo obshchestva "Rosneftegaz" za 2013 god [Annual Report for the open shareholding company Rosneftegaz for 2013] (Moscow: OAO Rosneftegaz) 
Rosneftegaz (2015) Godovoi otchet otkrytogo aktsionernogo obshchestva "Rosneftegaz" za 2014 god [Annual Report for the open shareholding company Rosneftegaz for 2014] (Moscow: OAO Rosneftegaz)

Rossiiskaya gazeta (1999) "Dokhodov - nul', zato Mersedesov - kucha [Zero income and a heap of Mercedeses]" Rossiiskaya gazeta, 17 November

Rybal'chenko, I. and Razumovskii, K. (2001) "Ukraina khochet poluchat' energiyu RAO 'EES Rossii' [Ukraine wishes to rceive energy from Russia's RAO UES]" Kommersant, 16 August, p.4

Sabonis-Helf, T. (2007) "The unified energy systems of Russia (RAO-UES) in Central Asia and the Caucasus: nets of interdependence", Demokratizatsiya, 15 (4): 429-444

Shmagun, O. et al. (2019) "Koshelek rossiiskoi elity. Kak ustroena ofshornaya imperiya 'Troiki Dialog'. Rassledovanie OCCRP [The wallet of the Russian elite. How Troika Dialog's offshore empire was set up. An OCCRP investigation]" Meduza.io, 4 March

Sikamova, A. and Efimov, A. (2003) "Chubaisa v Gruzii ne zhdali. Pokupka RAO 'EES Rossii' znachtel'noi chasti gruzinskoi energosistemy vyzvala volnu protestov $\mathrm{v}$ Tbilisi [Chubais was not expected in Georgia. RAO UES's acquisitions of a considerable share of the Georgian power system caused a wave of protest in Tbilisi]" Nezavisimaya gazeta, 7 August, p.3

Siluyanova, P. (2003a) "Elektroshok dlya Eduarda Shevardnadze [An electric shock for Eduard Shevardnadze]" Gazeta, 7 August, p. 8

Siluyanova, P. (2003b) “Bor'ba. 'Rosenergoatom' snizhaet eksport [Struggle. Rosenergoatom decreases export]" Gazeta, 11 August, p.8

Siluyanova, P. (2004a) "Plany. 'My igraem v kapitalizatsiyu' [Plans. 'We are working on capitalisation']" Gazeta, 7 September, p.11

Siluyanova, P. (2004b) "Oblom. Anatolii Chubais proigryvaet match [Failure. Anatolii Chubais loses a game]" Gazeta, 17 March, p.10

Siluyanova, P. (2004c) "Ekspansiya. Politicheskii rubil'nik [Expansion. A political knife-switch]" Gazeta, 7 September, p.11

Siluyanova, P. (2005) "Sdelka. Na svoi strakh i risk [Deal. At one's own risk]" Gazeta, 2 February, p. 9

Simonyan, Yu. (2009) "Nepriznannaya Inguri GES [The unrecognised Enguri hydropower plant]" Nezavisimaya gazeta, 20 January, p.1

Skorlygina, N. (2014) “'Rosneftegaz' zaplatit za Kirgiziyu v obmen na aktsii 'RusGidro" Kommersant, 14 March, p.12

Skorlygina, N. and Dzaguto, V. (2012) “'Inter RAO” slivaet dolgi Laosa [Inter RAO merges Laos's debts]" Kommersant, 22 February, p.9

Skyner, L. (2010) "The reform of the Russian power sector: the rhetoric and reality", Europe-Asia Studies, 62 (8): 1383-1402

Smirnov, K. (2000) "Dvenadtsat' [The twelve]" Kommersant-Vlast', 11 July, p.16

Smirnov, K. (2002) "Prezident predlozhil zamorozit' zakon [The president suggested to freeze the law]" Kommersant, 14 January 2002, p.3

Smirnov, K. (2004) "Ot administratsii k elektrifikatsii [From administration to electricification]" Kommersant-Den'gi, 29 March

Solanko, L. (2011) How to succeed with a thousand TWh reform? Restructuring the Russian power sector. FIIA Working Paper. 68. (Helsinki: The Finnish Institute of International Affairs) 
Solanko, L. (2014) "Securing electricity supply for a growing economy" in Oxenstierna, S. and Tynkkynen, V.-P. ed., Russian energy and security up to 2030 (Abingdon: Routledge) pp.129-149

Solov'ev, V. (2006) "Respublika Polurussiya [The Semirussian republic]" KommersantVlast', 10 April, pp.52-56

Solov'ev, V. and Dzaguto, V. (2017) "Moldaviya perekhodit na ukrainskie vatty [Moldova transfers to Ukrainian watts]" Kommersant, 3 April, p.1

Solov'ev, V. and Grishkovets, E. (2008) "Vakhsh vlivaetsya v rossiiskuyu energetiku [Vakhsh flows into Russian electricity]" Kommersant, 23 July, p.6

Solov'ev, V. and Popov, V. (2007) "Nevol'nik mesti [A slave of revenge]" Kommersant, 10 July, p. 10

Stalker, A. (1995) "Ekonomicheskaya integratsiya v SNG [Economic integration in the CIS]" Kommersant, 27 May

Stanovaya, T. (2016) "Ideal'naya zhertva: kto stoit za presledovaniem Doda? [The ideal victim: Who is behind the persecution of Dod?]" Republic, 23 June

Startseva, A. (2003) "Chubais Plans 'Aggressive' Expansion in CIS" The Moscow Times, 9 September, p.5

Stepanenko, S. (2003) "Chem bol'she svyazuyushchikh zven'ev, tem krepche sotrudnichestvo [The more connecting links, the stronger the cooperation]" Vremya novostei, 18 July, p.5

Stepanenko, S. and Gorelov, N. (2001) "I vashim i nashim. Rossiiskie i ukrainskie energetiki nikak ne dogovaryatsya [For yours and ours. Russian and Ukrainian power sector people cannot agree in any way]" Vremya novostei, 5 April, p.5

Sterkin, F. and Mazneva, E. (2011) "Ravnoudalenie kompanii [The equidistancing of companies]" Vedomosti, 4 April

Suvorova, N. (2004) "Rossiya pokupaet SSSR [Russia is buying the USSR]" Versiya, 6 September

TGK-1 (2012) Godovoi otchet OAO TGK-1 2011 [Annual report OAO TGK-1 2011] (St. Petersburg: TGK-1)

The Moscow Times (2009) "Inter RAO's Dod tapped for RusHydro" The Moscow Times, 23 November

Tompson, W. (2004) Restructuring Russia's Electricity Sector: Towards Effective Competition or Faux Liberalisation? OECD Economics Department Working Papers. 403. (Paris: OECD Publishing)

Tovkailo, M., Derbilova, E. and Lyutova, M. (2012) "Sechin protiv Medvedeva [Sechin against Medvedev]" Vedomosti, 12 January

Tregubova, E. (2000) "Vlast' dolzhna byt' zhestkoi [The powers should be tough]" Kommersant-Vlast', 1 August

Turanov, S. (2006) “50 naibolee vliyatel'nykh predprinimatelei i investorov [The 50 most influential businessmen and investors]" Nezavisimaya gazeta, 28 July, p.11

Ul'yanov, V. (2015) "Tainy pridnestrovskogo dvora [The secrets of the Transistrian Court]" Voenno-promyshlennyi kur'er, 25 November, p.4

Urikhanyan, A. (2001) "Pereraspredelenie topliva i kapitala v pol'zu Rossii [The redistribution of fuel and capital in favour of Russia]" Vremya MN, 24 October, p.3

Vardul', N. (2003) "Molchat' [Stay silent]" Kommersant, 28 October, p.1

Varfolomeyev, O. (2015) "Ukraine turns to Russia in energy crisis" Eurasia Daily Monitor, 12 January

Varfolomeyev, O. (2017) "Ukraine moves to integrate its power grid with European network" Eurasia Daily Monitor, 12 July 
Vasil'ev, I.V. (2012) “Otchet o rezul'tatakh kontrol'nogo meropriyatiya 'Proverka organizatsii tamozhennogo kontrolya pri peremeshchenii cherez tamozhennuyu granitsu Rossiiskoi' Federatsii tovarov po liniyam elektroperedachi, formirovaniya kontraktnykh tsen, pravil'nosti ischisleniya, polnoty i svoevremennosti uplaty tamozhennykh platezhei v 2009-2010 godakh i istekshem periode 2011 goda' [Account of the results of the control measure 'Control of the organisation of customs control of the movement of goods across the customs border of the Russian Federation on electricity transmission lines, of contract price formation, correct calculation, full and timely duty payments in 2009-10 and to date in 2011']" Byulleten' Schetnoi' palaty Rossii'skoi' Federatsii, February, pp.45-69

Vedeneeva, A. (2018) “'Lider' posylayut na 'Zvezdu' [Lider will be sent to Zvezda]" Kommersant, 28 July, p.1

Vedomosti (2008) "Vektor. Svobodnyi vybor [Vector. Free choice]" Vedomosti, 28 July

Vignanskii, M. (2003) "Chubais snyal ministra energetiki Gruzii. David Mirtskhulava ne vyderzhal obvinenii v prorossiiskoi orientatsii [Chubais removed the Georgian energy minister. David Mirtskhulava could not stand up to accusations of being pro-Russian]" Vremya novostei, 13 August, p.2

Vin'kov, A. (2005) "Attraktsion shchedrosti [The attraction of generosity]" Ekspert, 31 October, pp. $28-30$

Vin'kov, A. (2008) "Gosudarstvo - eto ty! [You are the state]" Ekspert, 14 January, pp.28-31

Vorotynskii, I. (2000) "Sto dnei dlya energetiki [A hundred days in energy]" Nezavisimaya gazeta, 15 February

Vostochnaya energeticheskaya kompaniya (2018) "Istoriya [History]" [online]. (Blagoveshchensk: Vostochnaya energeticheskaya kompaniya). Available from: http://easternec.ru/about_company/history/ [Accessed 12 October 2018]

Wengle, S.A. (2012) "Engineers versus managers: experts, market-making and statebuilding in Putin's Russia" Economy and Society, 41 (3): 435-467

Wengle, S.A. (2014) Post-Soviet power. State-led development and Russia's marketization (Cambridge/New York: Cambridge University Press)

WNA (2018) "Nuclear power in Armenia" [online]. March 2018 (London: World Nuclear Association). Available from: http://www.world-nuclear.org/information-li brary/country-profiles/countries-a-f/armenia.aspx [Accessed 12 October 2018]

Yakoreva, A. (2016) "Chernaya dyra s polovinoi trilliona. Skol'ko deneg skopil 'Rosneftegaz' [A black hole with half a billion. How much money Rosneftegaz accumulated]" Republic (Slon) 1 November

Yur'ev, S. (2018) “Shpionskie igry Kariny Tsurkan [Karina Tsurkan's espionage games]" Moskovskii Komsomolets, 24 July, p.1

Zaets, I. (2003) "Medvedev v perevode na ukrainskii - eto Medvedchuk. Zachem glava putinskoi administratsii ezdil v Kiev i vstrechalsya s Kuchmoi? [Medvedev in Ukrainian is Medvedchuk. Why did the head of Putin's administration travel to Kyiv and meet Kuchma?]" Nezavisimaya gazeta, 18 December, p.1

Zateichuk, M. (2007) "Firtashu nuzhna energiya [Firtash needs energy]" Vedomosti, 7 November

Zhelenin, A. (2005) "Tushi svet! [Turn off the lights!]” Russkii kur'er, 25 July, p.6

Zhelenin, A. (2007) "Astana proshchaet Bishkeku dolgi [Astana remits Bishkek's debts]” Nezavisimaya gazeta, 13 July, p. 8 
Zvyagin, V. (2004) "Raznost' potentsialov ili potentsial raznykh [Differences in potential or the potential of being different]", Mirovaya energeticheskaya politika, 2003 (4): 50-54

Aalto, P. et al. (2017) "Russian nuclear energy diplomacy in Finland and Hungary", Eurasian Geography and Economics, 58 (4): 386-417

Agentstvo ekonomicheskikh novostei (1999) “Vypusk 'Biznes-fakt. Privatizatsiya' [Edition 'Business news. Privatization']”, Agentstvo ekonomicheskikh novostei, 23 April

Aleksandrov, Yu. (2004) "Monopolii. Ottsy i deti 'Gazproma' [Monopolies. Gazprom's fathers and sons]", Novoe vremya, 14 November, pp.20-22

Alieva, N. (1998) "Estestvennoi monopolii - OAO 'TVEL', po mneniyu ego prezidenta Vitaliya Konovalova, est' chto skazat' [OAO Tvel has something to say for the natural monopoly, according to president Vitalii Konovalov]", Vek, 29 January

Angelova, A. (2008) “AES 'Druzhba': Rossiya na rynke stran tsentral'noi i vostochnoi Evropy [NPP Friendship: Russia on the Central and East European market]", Indeks bezopasnosti, 14 (2): 97-116

Antonov, V., Bocharova, S. and Vaganov, A. (2005) "Dorvalsya do atomnykh milliardov. Kirienko stal khozyainom Rosatoma [Got hold of the nuclear billions. Kirienko head of Rosatom]", Nezavisimaya gazeta, 16 November, p.1

APEK (2017), Reiting vliyaniya krupnykh predprinimatelei i top-menedzherov toplivnoenergeticheskogo kompleksa $v$ iyune $2017 \mathrm{~g}$. [Rating of the influence of major businessmen and top managers in the fuel and energy complex, June 2017] [online]. 29 June (Moscow: Agentstvo politicheskikh i ekonomicheskikh kommunikatsii). Available from: http://apecom.ru/projects/item.php?SECTION_ID=102\&ELE MENT_ID=3803 [Accessed 18 March 2019]

ARKA News Agency (2014) "Rossiya pokroet chast' raskhodov na stroitel'stvo novoi AES v Armenii stoimost'yu v $\$ 4,5$ mlrd. - ministr [Russia will cover partial costs for construction of the new Armenian NPP up to $4.5 \mathrm{bn}$. US\$, says minister]" [online]. 4 July (Yerevan: ARKA News Agency). Available from: http://www.arka. am/ru/news/economy/rossya_pokroet_chast_raskhodov_na_stroitelstvo_novoy_aes_ v_armenii_stoimostyu_v_4_5_mlrd_ministr/ [Accessed 1 July 2019]

ARKA News Agency (2018) "Glava Minenergo ne vidit nasushchnoi neobkhodimosti $\mathrm{v}$ stroitel'stve novoi AES [The Head of the Energy Ministry does not see any urgent need to build a new NPP]" [online]. 25 May (Yerevan: ARKA News Agency). Available from: http://arka.am/ru/news/economy/glava_minenergo_ne_vidit_nasus hchnoy_neobkhodimosti_v_stroitelstve_novoy_aes/ [Accessed 9 November 2018]

Atomnaya strategiya (2009) "K 70-letiyu Evgeniya Olegovicha Adamova [To Evgenii Olegovich Adamov's 70th birthday]", Atomnaya strategiya, June 2009, pp.3-6

Atomredmetzoloto (2010) OAO "Atomredmetzoloto". Godovoi otchet za 2009 god [Atomredmetzoloto. Annual report for 2009] (Moscow: Atomredmetzoloto)

Atomredmetzoloto (2011) 2010 OAO “Atomredmetzoloto" godovoi otchet [2010 Annual report for Atomredmetzoloto] (Moscow: Atomredmetzoloto)

Audit Chamber (2014) Otchet o rezul'tatakh kontrol'nogo meropriyatiya "Proverka tselevogo i effektivnogo ispol'zovaniya byudzhetnykh sredstv, vydelennykh v 2011-2013 godakh na realizatsiyu meropriyatii po stroitel'stvu energoblokov na deistvuyushchikh atomnykh elektrostantsiyakh, svyazannykh s razvitiem atomnogo energopromyshlennogo kompleksa v ramkakh programmy deyatel'nosti gosudarstvennoi korporatsii po atomnoi energii "Rosatom" na dolgosrochnyi period (2009-2015 gody)" [Report on the results of the control activity "Verification of targeted and effective utilisation of budgetary funds issued in 2011-2013 to implement measures to construct units 
at operating atomic power plants in connection with the development of the atomic energy industrial complex within the activity programme of the state corporation for atomic energy Rosatom in the long term period (2009-2015)"] (Moscow: Byulleten' Schetnoi Palaty Rossiiskoi Federatsii)

Avoyan, S. (2008) "Armenia: Yerevan, Moscow set up uranium venture", Radio Free Europe/Radio Liberty, 25 April

Balmaceda, M.M. (2013) The Politics of Energy Dependency. Ukraine, Belarus and Lithuania between Domestic Oligarchs and Russian Pressure (Toronto: University of Toronto Press)

Barinov, V. (2014) “'Atomnye den'gi peredali po sledstvennoi linii [The atomic money were returned to the line of inquiry]", Kommersant, 22 September, p.4

Barsukov, Yu. and Dzaguto, V. (2018) "Belorussiya ukhodit ot Gazproma [Belarus goes away from Gazprom]", Kommersant, 5 September, p. 9

Belkina, O. (2006) "Sovmestnye usiliya [Joint efforts]", Megapolis, 31 July

Belova, A. (2008) "Itogi reformirovaniya atomnoi otrasli Rossii [A summary of the reforms in Russia's nuclear industry]", Indeks bezopasnosti, 14 (2): 141-146

Belton, C. (2009) "Rosatom agrees deal for stake in Uranium One", The Financial Times, 15 June

Belyakov, E. (2006) “'Atomprom' ostanovil svoi poluraspad ['Atomprom' stops its half-disintegration]", Gazeta, 7 December, p.13

Belyakov, E. and Sokolovskaya, M. (2007) "Metamorfozy Rosatoma [Rosatom's metamorphoses]", Gazeta, 9 October, p. 9

Belyaninov, K. (2001) "Strana nepuganykh i.o. [The country of fearless acting heads]", Novye Izvestiya, 31 August, p.1

Blagov, S. (2007) "Russia and Kazakhstan pursue energy partnership", Eurasia Daily Monitor, 4 April

Bogatykh, M. (1999) "Minatom dozrel. I vypolnil postanovlenie pravitel'stva [Minatom grew up. And carried out the government's decision]", Segodnya, 26 March

Bovt, G. (2007) “'Anna Belova: Loshchad' mozhno privesti k vode, no ee nel'zya zastavit' pit" [Anna Belova: You can take the horse to the water, but you cannot force her to drink]", Profil', 26 February, p.44-50

Bradford, P.A. (2009) "The nuclear renaissance meets economic reality", Bulletin of the Atomic Scientists, 65 (6): 60-64

Bukharin, O. (1995) "Integratsiya voennogo i grazhdanskogo yadernykh toplivnykh tsiklov v Rossii [Integration of the military and civilian nuclear fuel cycles in Russia]", Yadernyi kontrol', 1995 (9): 10-13

Butler, W.E. (2008) "Treaty capacity and the Russian state corporation", The American Journal of International Law, 102 (2): 310-315

Butrin, D., Kornysheva, A. and Kiseleva, E. (2006) "Atomokhod Sobyanina [Sobyanin's atomic move]", Kommersant, 29 May, p.1

Centrus Energy Corp. (2018) "Megatons to Megawatts" [online]. (Bethesda, Maryland: Centrus Energy Corp.). Available from: https://www.centrusenergy.com/ who-we-are/history/megatons-to-megawatts/ [Accessed 2 November 2018]

Chereshnev, S. (2004) "Yadernoe toplivo dlya Kremlya. Pomoshchnik prezidenta vozglavil kompaniyu 'TVEL' [Nuclear fuel for the Kremlin. The presidential aide heads the TVEL Company]", Izvestiya, 26 October, p.7

Cooper, J. (1991) The Soviet Defence Industry: Conversion and Reform (London: The Royal Institute of International Affairs/Pinter Publishers) 
Cooper, J. (2013) "The Russian economy twenty years after the end of the socialist economic system", Journal of Eurasian Studies, 4 (1): 55-64

Danielyan, E. (2007) "U.S. moves to help Armenia build new nuclear power plant", Eurasia Daily Monitor, 28 November

Danielyan, E. (2009) "Armenia presses ahead with nuclear power plant construction”, Eurasia Daily Monitor, 29 May

Davydov, I. (2008) "Voznya vokrug yadernoi energetiki [The troubles of nuclear energy]", Nezavisimaya gazeta, 15 January, p.19

Decree No. 61 (29/01/1992) O Ministerstve Rossiiskoi Federatsii po atomnoi energii [On the Ministry for atomic energy of the Russian Federation] (Moscow: President of the Russian Federation)

Decree No. 166 (08/02/1996) O sovershenstvovanii upravleniya predpriyatiyami yaderno-toplivnogo tsikla [On the improvement of management of enterprises in the nuclear fuel cycle] (Moscow: President of the Russian Federation)

Decree No. 446 (15/04/1993) Ob osobennostyakh privatizatsii predpriyatii, nakhodyashchikhsya $v$ vedenii Ministerstva Rossiiskoi Federatsii po atomnoi energii, $i$ upravleniya imi $v$ usloviyakh razvitiya rynochnoi ekonomiki [On the particularities of privatisation of the enterprises that fall under the authority of the Ministry of atomic energy of the Russian Federation, and on management in the circumstances of the development of a market economy] (Moscow: President of the Russian Federation)

Delovaya stolitsa (2008a) "Vremya obogashchat'. Ukraina yaderno kooperiruetsya s Rossiei i Kazakhstanom [It's time to enrich. Ukraine in nuclear cooperation with Russia and Kazakhstan]", Delovaya stolitsa, 9 July

Delovaya stolitsa (2008b) "Gruppa kontaktov. Ukraina vplotnuyu vzyalas' za diversifikatsiyu istochnikov postavok yadernogo topliva [Contact group. Ukraine has begun in earnest to diversify supply sources for nuclear fuel]", Delovaya stolitsa, 7 April

Delovaya stolitsa (2010a) "Geny sovetskogo atoma. Ukraina doverila svoyu atomnuyu energetiku rossiyanam [The Soviet atom's genes. Ukraine entrusts its nuclear power sector to the Russians]", Delovaya stolitsa, 1 November

Delovaya stolitsa (2010b) "Rezerv nakachali uranom. Ukrainskie atomshchiki popytayutsya sokratit' zavisimost' ot Rossii [A reserve pumped up on uranium. The Ukrainian nuclear sector try to limit the dependence on Russia]", Delovaya stolitsa, 18 January

Delovaya stolitsa (2011) "CHAO, atom. Ukraina peredaet korporativnye prava na svoe yadernoe budushchee Rossii [Ciao, atom. Ukraine transfers its corporate rights to a nuclear future to Russia]", Delovaya stolitsa, 18 September

Dyatel, T. (2017) "Mirnyi atom otkladyvayut v dolgii yashchik [The peaceful atom is shelved]", Kommersant 25 October, p.1

Dye, M., Höglund, J. and Benjaminsson, U. (2015) "Diversification of the VVER fuel market" [online]. 30 September Nuclear Engineering International). Available from: https://www.neimagazine.com/features/featurediversification-of-the-vver-fuel-ma rket-4682502/ [Accessed 1 July 2019]

Dzaguto, V. (2009) "Energetikam ogranichili investsostavlyayushchuyu [The investment surcharge is reduced for the electricity sector]", Kommersant, 23 December, p.11

Dzaguto, V. (2010a) "Rossiya dostroit Khmel'nitskuyu AES i sama za eto zaplatit [Russia completes the Khmelnitskyy NPP and also pays for it]", Kommersant, 10 June, p.11

Dzaguto, V. (2010b) "Rossiya i Ukraina ob" edinyatsya na atomnom urovne [Russia and Ukraine will unite at the atomic level]", Kommersant, 28 April, p.9 
Dzaguto, V. (2011a) “"Rosatom” vyros v "renessanse" i nadeetsya uderzhat'sya na fone padeniya rynka [Rosatom grew during the "renaissance" and hopes to hold its ground in the falling market]", Kommersant, 29 September, p.11

Dzaguto, V. (2011b) “"Rosatomu” ukazali ego mesto na rynke yadernogo topliva Ukrainy [Rosatom is shown its place in Ukraine's nuclear fuel market]", Kommersant, 22 August, p.9

Dzaguto, V. (2011c) "Rossiya i Ukraina razzhigayut yadernoe toplivo [Russia and Ukraine kindle the nuclear fuel]", Kommersant, 3 February, p.9

Dzaguto, V. (2016) "Atom tak prosto ne otpuskaet [The atom does not let go that easily]", Kommersant, 6 October, p.4

Dzaguto, V. and Dzhumailo, A. (2018) “'Rosatom' slivaet dokhody [Rosatom merges its incomes]", Kommersant, 11 January, p.9

Dzaguto, V., Barsukov, Yu. and Kozlov, D. (2016a) "Belorusskaya AES mozhet podvinutsya [The Belarusian NPP may move further]", Kommersant, 2 August, p.9

Dzaguto, V. et al. (2016b) "Isotop Sergeya Kirienko [Sergei Kirienko's isotope]", Kommersant, 6 October, p. 1

Dzyadko, T. and Ivankina, E. (2014) "Sechin blokiruet "Inter RAO” [Sechin blocks Inter RAO]”, RBK Daily, 20 January, p.1

Embassy Astana (2009) Kazakhstan: Russian hand in Kazatomprom drama?, 09ASTANA2197/Wikileaks \#241141. Issue date 22 December 2009. Cablegate [online]. (Published by Wikileaks 1 September 2011). Available from: https://search. wikileaks.org/plusd/cables/09ASTANA2197_a.html [Accessed 14 November 2018]

Embassy Kyiv (2008) Ukraine's dependence on Russian energy, 08KYIV2358/Wikileaks \#180940. Issue date 2 December 2008. Cablegate [online]. (Published by Wikileaks 1 September 2011). Available from: https://search.wikileaks.org/plusd/ca bles/08KYIV2358_a.html [Accessed 1 July 2019]

Embassy Kyiv (2010) Ukraine's Deputy PM on money laundering, elections, IMF, 10KYIV193_a. Issue date 5 February 2010. Cablegate [online]. (Published by Wikileaks 1 September 2011). Available from: https://wikileaks.org/plusd/cables/ 10KYIV193_a.html [Accessed 16 November 2018]

Embassy Moscow (2007a) Russia: Vladimir Travin named to head Atomenergoprom, 07MOSCOW3407/Wikileaks \#115159. Issue date 12 July 2007. Cablegate [online]. (Published by Wikileaks 1 September 2011). Available from: https://search.wikilea ks.org/plusd/cables/07MOSCOW3407_a.html [Accessed 1 July 2019]

Embassy Moscow (2007b) Russia: Ambassador's April 26 meeting with Audit Chamber Chairman Stepashin, 07MOSCOW1960/Wikileaks \#106069. Issue date 27 April 2007. Cablegate [online]. (Published by Wikileaks 1 September 2011). Available from: https:// search.wikileaks.org/plusd/cables/07MOSCOW1960_a.html [Accessed 1 July 2019]

Embassy Moscow (2007c) Russia: MFA caught off guard by Burma nuclear deal, 07MOSCOW2316/Wikileaks \#108794. Issue date 18 May 2007. Cablegate [online]. (Published by Wikileaks 1 September 2011). Available from: https://search.wikilea ks.org/plusd/cables/07MOSCOW2316_a.html [Accessed 1 July 2019]

Embassy Moscow (2008) Commentators underscore continuity in assessing new government, 08MOSCOW1336/Wikileaks \#153704. Issue date 13 May 2008. Cablegate [online]. (Published by Wikileaks 1 September 2011). Available from: https://search. wikileaks.org/plusd/cables/08MOSCOW1336_a.html [Accessed 1 July 2019]

Emel'yanenko, V. (1998) "Ukroshchenie stroptivogo [The taming of the obstinate]", Moskovskie novosti, 10 March, p.9 
Emel'yanenkov, A. (2006) "Renessans po Kirienko [A renaissance according to Kirienko]", Rossiiskaya gazeta, 5 July, p.1

Emel'yanenkov, A. (2007a) "Megatonny - nalevo, megavatty - napravo [Megatonnes to the left, megawatts to the right]", Rossiiskaya gazeta, 3 May, p.6

Emel'yanenkov, A. (2007b) "Krylatyi 'Rosatom' [Winged Rosatom]”, Rossiiskaya gazeta, 14 November, p.4

Emel'yanenkov, A. (2007c) "Usloviya diktuet zakazchik [The customer sets the conditions]", Rossiiskaya gazeta, 25 October, p.1

Emel'yanenkov, A. (2009) "Kazakhskii atom otdali Shol'niku [The Kazakh atom is transferred to Shkol'nik]", Rossiiskaya gazeta, 4 June, p.6

Emel'yanenkov, A. (2010) "Nedelimyi atom [The indivisible atom]", Rossiiskaya gazeta, 30 April, p.6

Energoatom (2010) NAEK "Energoatom" NNEGC "Energoatom" (Kiyv: Energoatom)

Energoatom (2018) "Presidents of Energoatom and Westinghouse discussed the progress of implementation of Westinghouse nuclear fuel at Ukrainian nuclear power plants" [online]. 30 May (Kyiv: Energopatom). Available from: http://www.energoatom.kiev.ua/ en/actvts/international/international_activities/53881-presidents_of_energoatom_and_ westinghouse_discussed_the_progress_of_implemenation_of_westinghouse_nuclear_ fuel_at_ukranian_nuclear_power_plants/[Accessed 15 November 2018]

EURATOM Supply Agency (2015) Annual Report 2014. (Luxembourg: EURATOM/ European Union)

EURATOM Supply Agency (2018) "Nuclear Fuel Cycle - Front End" [online]. n.d. (Luxembourg: EURATOM/European Union). Available from: http://ec.europa.eu/ euratom/observatory_segments_e.html [Accessed 22 November 2018]

Fadeeva, A. (2014) “Atomnaya peregruzka [Atomic overload]", Vedomosti, 2 October, p.13 Faizullaev, D.A. (2009) "Tsentral'noaziatskii atomnyi "renessans" [The Central Asian nuclear "renaissance']", Aziya i Afrika segodnya, 2009 (8): 25-31

Federal Law No. 13 (05/02/2007) Ob osobennostyakh upravleniya i rasporyazheniya imushchestvom i aktsiyami organizatsii, osushchestvlyayushchikh deyatel'nost'v oblasti ispol'zovaniya atomnoi energii, i o vnesenii izmenenii v otdel'nye zakonodatel'nye akty Rossiiskoi Federatsii [On the peculiarities of management and direction of property and shares by organisations that carry out their business in the field of atomic energy, and on changes to separate acts of legislation of the Russian Federation] (Moscow: The Federal Assembly)

Federal Law No. 57 (29/04/2008) O poriadke osushchestvleniya inostrannykh investitsii $v$ khozyaistvennye obshchestva, imeyushchie strategicheskoe znachenie dlya natsional'noi bezopasnosti Rossiiskoi Federatsii [On the realisation of foreign investments in entities with a strategic significance for the Russian Federation's national security] (Moscow: The Federal Assembly)

Federal Law No. 317 (01/12/2007) O Gosudarstvennoi korporatsii po atomnoi energii "Rosatom" [On the State corporation for atomic energy "Rosatom"] (Moscow: The Federal Assembly)

Ferguson, C.G. (2009) “A nuclear renaissance?” in Luft, G. and Korin, A. ed., Energy Security Challenges for the 21st Century (Santa Barbara/Denver/Oxford: Praeger Security International), pp.295-307

Filatova, I. (2009) "Clock ticking on state corporations", The Moscow Times, 22 October, p.1

Fomicheva, A. (2015) "Byudzhet perevedut na bystrye neitrony [The budget is transferred to fast neutrons]", Kommersant, 8 April, p.9 
Garnett, S.W. (1995) “Ukraine's decision to join the NPT”, Arms Control Today, 25 (1): 7-12

Gorbenko, P. (2010) "Ukrainskaya simfoniya dlya TVELa [A Ukrainian symphony for TVEL]", Vestnik Atomproma, October, p.20-24

Gorelov, N. (2007) "Rynok s 'dopolnitel'nymi soglasheniyami' [A market with 'extra agreements']", Vremya novostei, 17 January, p.8

Gorst, I. (2009) "Kazakhs charge ex-head of atomic power", The Financial Times, 28 May

Gorst, I. (2010) "Former Kazakh nuclear chief given jail term", The Financial Times, 12 March

Gorst, I. and Simon, B. (2010) "Rosatom launches global charm offensive", The Financial Times, 1 September

Gotova, N. (1998) "Gryaznye tantsy na reaktore [Dirty dancing on the reactor]", Moskovskii Komsomolets, 10 December

Government Order No. 775 (22/04/1992) O chlenakh kollegii Ministerstva Rossiiskoi Federatsii po atomnoi energii [On members of the collegium of the Ministry of atomic energy of the Russian Federation] (Moscow: The Government of the Russian Federation)

Government Resolution No. 175 (19/03/1992 (22/09/1993)) Voprosy Ministerstva Rossiiskoi Federatsii po atomnoi energii [On the question of the Ministry of atomic energy of the Russian Federation] (Moscow: The Government of the Russian Federation)

Government Resolution No. 506-12 (02/06/2014) Ob utverzhdenii gosudarstvennoi programmy Rossiiskoi federatsii "Razvitie atomnogo energopromyshlennogo kompleksa" [On the confirmation of the state programme of the Russian Federation "Development of the atomic energy industry complex"] (Moscow: The Government of the Russian Federation)

Government Resolution No. 605 (06/10/2006) O Federal'noi tselevoi programme "Razvitie atomnogo energopromyshlennogo kompleksa Rossii na 2007-2010 gody $i$ na perspektivu do 2015 goda" [On the Federal development programme 'Development of the Russian atomic energy industry complex in 2007 to 2010 and towards 2015] (Moscow: The Government of the Russian Federation)

Government Resolution No. 815 (21/07/1998) Ob utverzhdenii Programmy razvitiya atomnoi energetiki Rossiiskoi federatsii na 1998-2005 gody i na period do 2010 goda [On the confirmation of a Development programme for the atomic energy industry of the Russian Federation in 1998 to 2005 and the period to 2010] (Moscow: The Government of the Russian Federation)

Grudnitskii, P. (2006a) "Uranovyi tandem [A tandem in uranium]", Ekspert, 23 October, pp.54-55

Grudnitskii, P. (2006b) "Uran - nashe vse [Uranium is our everything]", Ekspert Kazakhstan, 21 May

Hashimova, U. (2011) "East-West diplomacy of the Uzbek President”, Eurasia Daily Monitor, 17 February

Heath, J.R. (2009) "Strategic protectionism? National security and foreign investment in the Russian Federation", George Washington International Law Review, 41 (2009): 101-137

Humber, Y. (2006) "Putin revives nuclear alliance", The Moscow Times, 13 January, p.1

Ibragimova, G. (2010) “Atomnaya energetika v Tsentral'noi Azii: Est' li perspektivy? [Nuclear energy in Central Asia: is there a future?]", Indeks bezopasnosti, 16 (4): $77-103$

IMF (2014) Russian Federation. Fiscal Transparency Evaluation. IMF Country Report. (Washington, DC: International Monetary Fund) 
Ioffe, G. (2011) "Washington struggles to formulate strategy on Belarus", Eurasia Daily Monitor, 12 December

Ioffe, G. (2016) "Possible nuclear plant accident in Belarus sheds light on Minsk's internal political process", Eurasia Daily Monitor, 1 August

IUEC (2019) "Key dates” [online]. n.d. (Angarsk: International Uranium Enrichment Center,). Available from: http://eng.iuec.ru/about/dates/ [Accessed 1 July 2019]

Ivanitskaya, N. et al. (2008) "Nesvoevremennyi vizit [An untimely visit]", Vedomosti, 28 April

Ivanov, V. and Rogozhin, Yu. (2006) "Energetika: Kak postroit' atom [Energy: How to build the atom]", Vedomosti, 28 September

Ivzhenko, T. (2009a) "Kiev rasschityvaet na rossiiskii atomnyi kredit [Kyiv counts on Russia's atomic credit]", Nezavisimaya gazeta, 25 September, p.6

Ivzhenko, T. (2009b) "V Kieve tyanut vremya [Kyiv plays for time]", Nezavisimaya gazeta, 14 July, p.6

Ivzhenko, T. (2010) “Trekhmernyi atom Viktora Yanukovicha [Viktor Yanukovich's three-dimensional atom]", Nezavisimaya gazeta, 17 September, p.1

Ivzhenko, T. (2011) "Mirnyi atom mozhet razdelit'sya [The peaceful atom may split]", Nezavisimaya gazeta, 25 March, p.6

Jeppesen, M. (2006) Russland og arbeidet med kjernefysisk ikke-spredning: en kartleggingsstudie [Russia and the nuclear non-proliferation process: An exploratory study]. FFI Rapport (Kjeller, Norway: Norwegian Defence Research Establishment)

Kadosov, D. (1992a) "Rossiya boretsya za rynki urana [Russia fights for uranium markets]", Kommersant, 27 November

Kadosov, D. (1992b) "Sozdaetsya AO 'Atomredmet' [Atomredmet stock company is founded]", Kommersant, 11 December

Kadosov, D. (1993) "Soglashenie proizvoditelei urana [Agreement among uranium producers]", Kommersant, 25 February

Kasperski, T. (2015) "Nuclear dreams and realities in contemporary Russia and Ukraine”, History and Technology: An International Journal, 31 (1): 55-80

Kats, E. (1999) "Ubytochnyi biznes 'generalov ot radiatsii' [The 'radiation generals' unprofitable business]", Segodnya, 9 February

Katys, M. (2001) "Vvoz otrabotavshikh yadernykh otkhodov [The import of spent nuclear waste]" [online]. 21 February 2001 (Prague: Radio Svoboda). Available from: https://www.svoboda.org/a/24197716.html [Accessed 31 January 2019]

Kazatomprom (2016) Godovoi otchet. 2015 [Annual Report. 2015] (Astana: Kazatomprom)

Khachatrian, H. (2008) "Armenia: Contemplating life as a regional electricity exporter", Eurasianet.org, 30 October

Khripunov, I. (2001) "MINATOM: Time for crucial decisions", Problems of PostCommunism, 48 (4): 49-58

Khvostik, E. et al. (2018) "Bryussel' stavit blok Armyanskoi AES [Brussels puts on the Armenian NPP's reactor]”, Kommersant Daily, 31 January, p.7

Kiselev, S. (2011) "Rossiiskie atomshchiki zakreplyayutsya v Evrope [The Russian nuclear sector gains positions in Europe]", Nezavisimaya gazeta, 12 September, p.4

Kluge, J. (2019) Mounting Pressure on Russia's Government Budget. Financial and Political Risks of Stagnation. SWP Research Paper (Berlin: Stiftung Wissenschaft und Politik)

Kommersant (1992) "Vizit rossiiskikh atomshchikov v Iran [Russian nuclear specialists' visit to Iran]", Kommersant, 27 October 
Koretskii, A. (1994) "Uranovaya sdelka mezhdu Kazakhstanom i SShA [An uranium deal between Kazakhstan and US]", Kommersant, 25 November

Koretskii, A. (1997) "Rossiiskie atomnye 'tabletki' vyzyvayut v Kieve allergiyu [Russian nuclear 'pills' cause allergy in Kiev]", Segodnya, 3 April

Kornysheva, A. (2005a) "V 'Rosenergoatome' smenilsya rukovoditel'. Stanislav Antipov naznachen otvetsvennym za aktsionirovanie kontserna [Change of hands in Rosenergoatom. Stanislav Antipov placed in charge of incorporation of the concern]", Kommersant, 7 May, p.5

Kornysheva, A. (2005b) "Reforma energetiki. Rosatom gotov k aktsionernoi sobstvennosti [Electricity reform. Rosatom is ready for shareholding property]", Kommersant, 4 April, p. 15

Kornysheva, A. (2006a) “'TVEL' i 'Tekhsnabeksport' ostanutsya samostoyatel'nymi yurlitsami" ['TVEL' and 'Tekhsnabeksport' will remain independent juridical persons]", Kommersant, 11 September, p.5

Kornysheva, A. (2006b) 'Atomnaya promyshlennost'. TVEL i 'Tekhsnabeksport' sozdayut gornorudnuyu kompaniyu [Atomic industry. TVEL and 'Tekhsnabeksport' will create a mining company]", Kommersant, 18 July, p.10

Kornysheva, A. (2007a) "Rossiiskii uran budet bogache [Russian uranium will become richer]", Kommersant, 23 June, p.5

Kornysheva, A. (2007b) "Rosatom razgonyayut na apparatnom uskoritele [Speeding up Rosatom on the bureaucratic accelerator]", Kommersant, 5 October, p.14

Kornysheva, A. (2007c) "Ukraina zasvetila atomnye tseny [Ukraine illuminates nuclear prices]", Kommersant, 8 May, p.11

Kornysheva, A. and Chernovalov, A. (2007) "Ukraina vybila iz Rossii atomnuyu skidku [Ukraine manages to get an atomic discount from Russia]", Kommersant, 17 January, p.12

Kornysheva, A., Yambaeva, R. and Grib, N. (2006) "Rosatom sdaet aktivy v 'Atomprom' [Rosatom will place its equity in 'Atomprom']”, Kommersant, 9 February, p.15

Koroleva, N. (2006) "Viktor Mikhailov: Sergeya Kirienko naznachal Predsedatel' Pravitel'stva, a ego reshenie nuzhno uvazhat' [Viktor Mikhailov: The Prime Minister appointed Sergei Kirienko, and we should respect the decision]”, Atomnaya Strategiya, March, p.3

Kosharnaya, O. (2009) "Plan 'ponuzhdeniya' k sotrudnichestvu [A plan for 'forced' cooperation]", Zerkalo Nedeli, 9 October

Kotlyar, E. (2012) "Oboronosposobnost' strany, prevrashchennaya v zoloto [The country's defence capacity is converted to gold]", Moskovskaya pravda, 10 August, p.9

Kovynev, A. (2017) "Nuclear power in Ukraine - 40 years of unease", Nuclear Engineering International. Available from: https://www.neimagazine.com/features/featur enuclear-power-in-ukraine-40-years-of-unease-5956752/ [Accessed 5 April 2020]

Krasavin, A. (2007) "Gosmonopol'zovanie [State monopoly-utilization]", Itogi, 8 October

Kravchenko, E. (1994) “Krupnyi kontrakt 'Tekhsnabeksporta' [A major contract for Tekhsnabeksport]”, Kommersant, 12 January

Kucherenko, V. (2000) "Kirgiziya vstupaet v 'uranovyi proekt' s Rossiei [Kyrgyzstan enters a 'uranium project' with Russia]", Rossiiskaya gazeta, 23 December, p.7

Kudrik, I. et al. (2004) The Russian nuclear industry. Bellona Report. 4 (Oslo, Norway: The Bellona Foundation)

Kudrin, Yu. (2008) "S Rossiei nadezhnee [It is safer with Russia]", Rossiiskaya gazeta, 24 March, p.3 
Kudryashov, D. (2006) “Kirienko naznachaet 'svoikh' [Kirienko appoints loyal hands]", Gazeta, 17 March, p.16

Kurdov, D. (2007) "Tupikovaya diversifikatsiya [Blind alley diversification]", Kievskii Telegraf, 2 July

Kuznetsov, A. et al. (2006) Korporatsiya "TVEL": pervye desyat' [The TVEL Corporation: The first decade] (Moscow: TVEL/OOO Izdatel'skii tsentr "Atompressa”)

Lavr, S. (1992) "Problema uranovoi torgovli ne snyata [The uranium trade problem remains]", Kommersant, 26 October

Leskov, S. (2006) "Smert' Sredmasha [The death of Sredmash]", Profil', 20 November, p.100

Loukianova, A. (2008) "The International Uranium Enrichment Center at Angarsk: A step towards assured fuel supply?", Nuclear Threat Initiative [online]. Available from http://www.nti.org/analysis/articles/uranium-enrichment-angarsk/ [Accessed 8 September 2014]

Malkova, I. (2006) "Nizhegorodskii universal [The universalist from Nizhnii Novgorod]", Vedomosti, 17 March

Malkova, I. and Mazneva, E. (2007) "Sozdaetsya atomnaya goskorporatsiya [An atomic state corporation is being formed]", Vedomosti, 5 October

Marples, D. (2006) "Lukashenka opts for nuclear power", Eurasia Daily Monitor, 6 December

Marples, D. (2008) "New revelations concerning nuclear power plant in Belarus", Eurasia Daily Monitor, 10 January

Marples, D. (2009) "Protests planned against Belarus nuclear plant", Eurasia Daily Monitor, 20 April

Marples, D. (2010) "Surge in nuclear power projects imperils Belarusian program", Eurasia Daily Monitor, 4 August

Marples, D. (2012) "Is Nuclear Power The Panacea For Belarusian Energy Problems?", Eurasia Daily Monitor, 5 March

Mashrab, F. (2018) "Uzbekistan and Russia reach agreement on construction of new nuclear power plant", Eurasia Daily Monitor, 10 July

Melikova, N. (2006) "Fenomen Sobyanina [The Sobyanin phenomenon]", Nezavisimaya gazeta, 13 November, p.7

Melikova, N. (2008) "Zheleznaya doroga za prezidentskii privet [A railway in return for the president's greetings]", Nezavisimaya gazeta, 7 February, p.5

Mikhailin, M. (1995) "Delo o khishchenii izotopov [The isotope theft case]", Kommersant, 25 February

Milov, V. (2015) “'Rosatom': itogi desyatiletiya [Rosatom: summing up a decade]”, Forbes, 15 October

Ministry of Energy (2009) Energeticheskaya strategiya Rossii na period do 2030 goda [Russia's Energy Strategy for the period to 2030] (Moscow: Institute of Energy Strategy)

Ministry of Industry and Trade (2003) Energeticheskaya strategiya Rossii na period do 2020 goda [Russia's Energy Strategy for the period to 2020) (Moscow: Ministerstvo promyshlennosti i torgovli)

Muzalevsky, R. (2010) "Japanese-Kazakh nuclear energy cooperation: a partnership for the future", Eurasia Daily Monitor, 2 August

Naumov, I. (2006) "Kirienko zastryal na starte. Reforma Rosatoma probuksovyvayut na normativno-pravovom pole [Kirienko gets stuck on the start line. The reform of Rosatom is spinning on the normative-legal field]", Nezavisimaya gazeta, 17 April, p.4 
NEI Magazine (2005) "Kazakhstan to become uranium player" [online]. 23 November (London: Nuclear Engineering International). Available from: https://www.neimagazine. com/news/newskazakhstan-to-become-uranium-player [Accessed 1 February 2019]

NEI Magazine (2009) "Areva and Kazatomprom to create fuel JV" [online]. 8 October (London: Nuclear Engineering International). Available from: https://www.neimagazine. com/news/newsareva-and-kazatomprom-to-create-fuel-jv/ [Accessed 15 November 2018]

NEI Magazine (2010a) "Russia picked to build fuel fabrication plant in Ukraine" [online]. 6 October (London: Nuclear Engineering International). Available from: https://www.neimagazine.com/news/newsrussia-picked-to-build-fuel-fabrication-plantin-ukraine/ [Accessed 16 November 2018]

NEI Magazine (2010b) "TVEL wins tender to build fuel plant in Ukraine" [online]. 1 November (London: Nuclear Engineering International). Available from: https://www. neimagazine.com/news/newstvel-wins-tender-to-build-fuel-plant-in-ukraine/ [Accessed 16 November 2018]

NEI Magazine (2010c) "Russia to pay for $85 \%$ of costs to complete Khmelnitsky $3 \& 4$ " [online]. 12 November (London: Nuclear Engineering International). Available from: https://www.neimagazine.com/news/newsrussia-to-pay-for-85-of-costs-to-comp lete-khmelnitsky-34/ [Accessed 20 November 2018]

NEI Magazine (2012a) "Russia-Ukraine nuclear fuel plant begins construction" [online]. 11 October (London: Nuclear Engineering International). Available from: https://www. neimagazine.com/news/newsrussia-ukraine-nuclear-fuel-plant-begins-construction/ [Acce ssed 19 November 2018]

NEI Magazine (2012b) "Russia signs VVER service agreement with Energoatom" [online]. 6 November (London: Nuclear Engineering International). Available from: https://www.neimagazine.com/news/newsrusatom-signs-vver-service-agreement-withenergoatom/ [Accessed 19 November 2018]

NEI Magazine (2015a) "Ukraine pushes ahead with fuel diversification" [online]. 16 November (London: Nuclear Engineering International). Available from: https://www. neimagazine.com/news/newsukraine-pushes-ahead-with-fuel-diversification-4720393/ [Accessed 20 November 2018]

NEI Magazine (2015b) "Ukraine looks to reduce nuclear fuel supplies from Russia" [online]. 24 August (London: Nuclear Engineering International). Available from: https://www.neimagazine.com/news/newsukraine-looks-to-reduce-nuclear-fuel-supp lies-from-russia-4653681/ [Accessed 19 November 2018]

NEI Magazine (2015c) "AREVA wins enrichment contract in Ukraine" [online]. 27 April (London: Nuclear Engineering International). Available from: https://www. neimagazine.com/news/newsareva-wins-enrichment-contract-in-ukraine-4562812/

[Accessed 19 November 2018]

NEI Magazine (2015d) "Russia: Surviving sanctions" [online]. 4 June (London: Nuclear Engineering International). Available from: https://www.neimagazine.com/ features/featurerussia-surviving-sanctions-4592602/ [Accessed 19 November 2018]

NEI Magazine (2016a) "Profits for TVEL" [online]. 5 July (London: Nuclear Engineering International). Available from: https://www.neimagazine.com/news/newsp rofits-for-tvel-4941492/ [Accessed 21 November 2018]

NEI Magazine (2016b) "Urenco to supply enriched uranium to Ukraine" [online]. 23 August (London: Nuclear Engineering International). Available from: https://www. neimagazine.com/news/newsurenco-to-supply-enriched-uranium-to-ukraine-4986122/ [Accessed 22 November 2018] 
NEI Magazine (2016c) "More Westinghouse fuel for Ukraine" [online]. 5 July (London: Nuclear Engineering International). Available from: https://www.neimaga zine.com/news/newsmore-westinghouse-fuel-ukraine-4941497/ [Accessed 21 November 2018]

NEI Magazine (2016d) "Continued Ukraine-Russia tensions over fuel" [online]. 7 June (London: Nuclear Engineering International). Available from: https://www.neimaga zine.com/news/newscontinued-ukraine-russia-tensions-over-fuel-4915829/ [Accessed 21 November 2018]

NEI Magazine (2016e) "Ukraine resumes nuclear fuel trade with Russia" [online]. 9 August (London: Nuclear Engineering International). Available from: https://www. neimagazine.com/news/newsukraine-resumes-nuclear-fuel-trade-with-russia-4974528/ [Accessed 21 November 2018]

NEI Magazine (2017a) "Ukraine presses on with used storage facility" [online]. 19 May (London: Nuclear Engineering International). Available from: https://www.neimagazine. com/news/newsukraine-presses-on-with-used-fuel-storage-facility-5819651/ [Accessed 22 November 2018]

NEI Magazine (2017b) "Ukraine increases nuclear share as power shortage looms" [online]. 22 February (London: Nuclear Engineering International). Available from: https://www.neimagazine.com/news/newsukraine-increases-nuclear-share-as-powershortage-looms-5744263/ [Accessed 22 November 2018]

NEI Magazine (2018a) "Ukraine's fuel priorities" [online]. 8 August (London: Nuclear Engineering International). Available from: https://www.neimagazine.com/features/ featureukraines-fuel-priorities-6703002/ [Accessed 22 November 2018]

NEI Magazine (2018b) "Canada's Brookfield to buy Westinghouse" [online]. 8 January (London: Nuclear Engineering International). Available from: https://www.neimaga zine.com/news/newscanadas-brookfield-to-buy-westinghouse-6021321/ [Accessed 4 December 2018]

NEI Magazine (2018c) "Orano signs contract with Ukraine on fuel reprocessing" [online]. 5 June (London: Nuclear Engineering International). Available from: https://www. neimagazine.com/news/newsorano-signs-contract-with-ukraine-on-fuel-reprocessing6175810/ [Accessed 22 November 2018]

NEI Magazine (2018d) "Areva NP becomes Framatome and Atmea is reorganised" [online]. 8 January (London: Nuclear Engineering International). Available from: https://www.neimagazine.com/news/newsareva-np-becomes-framatome-and-atmeais-reorganised-6021305/ [Accessed 4 December 2018]

NEI Magazine (2018e) "Turboatom and Westinghouse extend nuclear cooperation" [online]. 9 November (London: Nuclear Engineering International). Available from: https:/www.neimagazine.com/news/newsturboatom-and-westinghouse-extend-nuclearcooperation-6843967/ [Accessed 22 November 2018]

Neimysheva, N., Mazneva, E. and Nikol'skii, A. (2006) “Teplaya voda [Tepid water]", Vedomosti, 7 February

Nigmatulin, R.I. and Nigmatulin, B.I. (2006) 'Neft', gaz, energiya, mir, Rossiya: sostoyanie i perspektivy [Oil, gas, energy, the world, Russia: the state of affairs and the perspectives]", Atomnaya strategiya, January, p.11-13

Nikol'skii, A. (2005) “'Rosenergoatom' obmanuli [Rosenergoatom has been fooled]", Vedomosti, 27 June

Nikol'skii, A. (2006a) "Edinyi atom [United atom]", Vedomosti, 10 November 
Nikol'skii, A. (2006b) “Interv'yu: Sergei Obozov, gendirektor FGUP 'Rosenergoatom' [Interview: Sergei Obozov, general director of the federal enterprise 'Rosenergoatom']", Vedomosti, 27 September

Oganesyan, T. (1998) “Atomnye igry [Nuclear games]”, Ekspert, 11 May

Oilcapital.ru (2016) "Reiting vliyaniya krupnykh predprinimatelei $i$ top-menedzherov toplivno-energeticheskogo kompleksa v marte $2016 \mathrm{~g}$. [Rating of the influence of major businessmen and top managers in the fuel and energy complex, March 2016]" [online]. 29 March (Moscow: IG Industriya). Available from: https:/oilcapital.ru/news/compa nies/29-03-2016/reyting-vliyaniya-krupnyh-predprinimateley-i-top-menedzherov-topliv no-energeticheskogo-kompleksa-v-marte-2016-g [Accessed 20 February 2019]

Omelchenko, S. (2008) "Spornyi atom [The disputed atom]", Ekonomika i zhizn', 8 March, p.36

Orlov, V. (2008) "Sergei Kirienko. 'Pri sushchestvuyushchei seichas konkurentsii nevozmozhno byt' vtorym' [Sergei Kirienko. 'In the current competition, it is impossible to come second']", Indeks bezopasnosti, 14 (2): 11-14

Orlov, V.A. and Vinnikov, A. (2005) "The Great Guessing Game: Russia and the Iranian Nuclear Issue", The Washington Quarterly, 28 (2): 49-66

Osetinskaya, E. and Shcherbakova, A. (2001) "Piterskie kadry idut v Minatom [The Petersburg people are coming to Minatom]", Vedomosti, 8 June

Oxenstierna, S. (2010) Russia's Nuclear Energy Expansion. Defence Analysis (Stockholm: FOI Swedish Defence Research Agency)

Palamarchuk, S.I., Podkovalnikov, S.V. and Voropai, N.I. (2001) "Getting the electricity sector on track in Russia", The Electricity Journal, October 2001, pp.52-58

Panfilova, V. (2009) "Uzbekskii ryvok na zapad [An Uzbek dash to the West]", Nezavisimaya gazeta, 11 November, p.1

Pannier, B. (2009) "Link to Iran Spoils Kazatomprom Party" [online]. 30 December (Prague: Radio Free Europe/Radio Liberty). Available from: http://www.rferl.org/con tent/Link_To_Iran_Spoils_Kazatomprom_Party/1917808.html [Accessed 1 July 2019]

Pappe, Ya. and Drankina, E. (2007) "Kak natsionaliziruyut Rossiyu: atomnaya promyshlennost' [How Russia is being nationalised: the nuclear industry]", Kommersant-Den'gi, 24 September

Pavlov, D. (1998) "Skandal v Minatome [Scandal in Minatom]", Kommersant, 12 March, p.1

Pavlov, D. (1999) "Za rossiiskii uran zaplatyat strany NATO [Nato states will pay for Russian uranium]", Kommersant, 26 March, p.2

Pelekhova, Yu. (1998a) "Gazpromu predlozhili mirnyi atom [Gazprom is offered the peaceful atom]”, Kommersant, 7 May, p.9

Pelekhova, Yu. (1998b) "Rasshcheplenie Minatoma [The splitting of Minatom]", Kommersant, 28 April, p.1

Perera, J. (1997) The Nuclear Industry in the Former Soviet Union. Transition from Crisis to Opportunity. Vol I. 2 (London: Financial Times Energy Publishing)

Peschinskii, I. (2017) "Dorogoi mirnyi atom [The expensive peaceful atom]", Vedomosti, 26 September, p.14

Peschinskii, I. and Nikol'skii, A. (2016) "Likhachev vozglavil "Rosatom" [Likhachev heads Rosatom]", Vedomosti, 6 October, p.12

Podrobno.uz (2018) "Rossiiskii eksportnyi tsentr mozhet profinansirovat' stroitel'stvo AES v Uzbekistane [The Russian Export Centre may finance the construction of an NPP in Uzbekistan]" [online]. 25 April (Tashkent: Podrobno.uz). Available from: https://podrobno.uz/cat/uzbekistan-i-rossiya-dialog-partnerov-/rossiyskiy-eksportnyy 
-tsentr-mozhet-profinansirovat-stroitelstvo-aes-v-uzbekistane-/ [Accessed 9 November 2018]

Popov, A. (1995) “AES mogut ostanovit'. Terpenie personala rossiiskikh atomnykh stantsii istoshchaetsya [NPPs may be closed. Nuclear plant personnel's patience is becoming exhausted]", Nezavisimaya gazeta, 2 December

Prime-TASS (1997) "Ukraina i Rossiya sozdayut SP dlya obespecheniya yadernym toplivom ukrainskikh AES [Ukraine and Russia create JV to supply Ukrainian NPPs with fuel]", Prime-TASS, 22 October 1997

Proskurnina, O. and Nikol'skii, A. (2006) "Atom obrel reformatora [The atom has found its reformer]", Vedomosti, 9 February

Proskuryakov, L. and Buran, V. (1994) "TVEL Concern: Road to Amalgamation", International Affairs (Moscow), 1994 (9): 51-55

Putin, V. (2007) "Poslanie Federal'nomu Sobraniyu Rossiiskoi Federatsii Prezidenta Rossii Vladimira Putina [Address to the Federal Assembly of the Russian Federation by President Vladimir Putin]", Rossiiskaya gazeta, 27 April, p.3

Ravinskii, V. (2008) "Ukraina rasshchepila mirnyi atom [Ukraine splits the peaceful atom]", Kommersant, 10 April, p.14

RBK (2018) "RBK 500: Reiting rossiiskogo biznesa [RBK 500: The Russian Business Rating]" [online]. Moscow. Available from: https://www.rbc.ru/rbc500/ [Accessed 23 November 2018]

RBK Daily (2016) "Kto vmesto Kirienko [Who, instead of Kirienko]", RBK Daily, 6 October, p.5

RBK Daily (2017) “Kreditnaya zavisimost' [Credit dependence]”, $R B K$ Daily, 16 June, p.7

Regnum.ru (2012a) "Kazakhstanskomu obshchestvu nasazhdaetsya obraz vraga v litse Rossii: glava "Kazatomprom" [Kazakhstani society is is being inculcated with the image of Russia as an enemy - Kazatomprom's head]" [online]. 15 August (Moscow: Regnum). Available from: https://regnum.ru/news/polit/1561532.html [Accessed 15 November 2018]

Regnum.ru (2012b) “'Kazatomprom; sovmestno s 'TVEL' sozdayut sovmestnye moshchnosti po obogashcheniyu urana [Kazatomprom and TVEL establish joint capacities in uranium enrichment]" [online]. 23 November (Moscow: Regnum). Available from: https://regnum.ru/news/polit/1596706.html [Accessed 15 November 2018]

Regnum.ru (2013) “Tikhoe razmezhevanie' s Rossiei: Kazakhstan za nedelyu [A quiet demarcation with Russia: Kazakhstan this week]" [online]. 10 April (Moscow: Regnum). Available from: https://regnum.ru/news/polit/1646997.html [Accessed 15 November 2018]

Regnum.ru (2017a) "V povyshenii mirovykh tsen na uran vinovat Kazakhstan [Kazakhstan is to blame for the rise in the global uranium price]" [online]. 15 May (Moscow: Regnum). Available from: https://regnum.ru/news/economy/2274747.html [Accessed 15 November 2018]

Regnum.ru (2017b) "Ocherednaya AES na Ukraine perekhodit na amerikanskoe toplivo [Another NPP in Ukraine transfers to American fuel]" [online]. 11 December (Moscow: Regnum). Available from: https://regnum.ru/news/economy/2355822. html [Accessed 15 November 2018]

RFE/RL (2001) "RFE/RL Newsline", Radio Free Europe/Radio Liberty, 23 March RFE/RL (2007) "RFE/RL Newsline”, Radio Free Europe/Radio Liberty, 13 April RIA Novosti (2014) "Rossiya predostavit Armenii \$270 mln. na prodlenie sroka raboty AES [Russia extends \$270 million credit to prolong NPP operational 
period]" [online]. 26 December (Moscow: RIA Novosti). Available from: https://ria. ru/20141226/1040277548.html [Accessed 1 July 2019]

RIA Novosti (2016) "Rosatom v 2016 godu: k strategicheskim tselyam s novym rukovodstvom [Rosatom in 2016: towards strategic goals under a new management]" [online]. 30 December (Moscow: RIA Novosti). Available from: https://ria. $\mathrm{ru} / 20161230 / 1484960036 . \mathrm{html}$ [Accessed 28 November 2018]

Rodin, I. (2006) "Rosatom dvinulsya k privatizatsii [Rosatom got its privatization going]", Nezavisimaya gazeta, 7 November, p.1

Rosatom (2010) Publichnyi godovoi otchet 2009 [Annual report for the public 2009] (Moscow: Rosatom)

Rosatom (2013) Publichnyi godovoi otchet 2012 [Annual report for the public 2012] (Moscow: Rosatom)

Rosatom (2017) Publichnyi godovoi otchet 2016 [Annual report for the public 2016] (Moscow: Rosatom)

Rosatom (2018a) "Prezident RF V. Putin i Prezident Uzbekistana Sh. Mirzieev dali start proektu stroitel'stva pervoi AES v Uzbekistane [The president of the Russian Federation, V. Putin, and the president of Uzbekistan, Sh. Mirziyoyev, gave the start signal for the construciton project for the first NPP in Uzbekistan]" [online]. 19 October (Moscow: Rosatom). Available from: https://www.rosatom.ru/journalist/news/prezident-rf-vputin-i-prezident-uzbekistana-sh-mirzieev-dali-start-proektu-stroitelstva-pervoy-aes-/ [Accessed 9 November 2018]

Rosatom (2018b) Publichnyi godovoi otchet 2017 [Annual report for the public 2017] (Moscow: Rosatom)

Rosenergoatom (2013) Godovoi otchet 2012 [Annual report 2012] (Moscow: Rosenergoatom)

Rubtsov, A. (1999) "Rossiisko-amerikanskii yadernyi konflikt [The Russian-American nuclear conflict]", Kommersant, 24 November

Rykovanova, E. (2006) "Rossiiskaya initsiativa po sozdaniyu sistemy mezhdunarodnykh tsentrov po predostavleniyu uslug yadernogo toplivnogo tsikla [The Russian initiative to create a system of international centres to provide nuclear fuel cycle services]", Voprosy bezopasnosti, 2006 (May)

Sandler, Yu. (2010) "Bratskii atomnyi soyuz [The brotherly atomic union]", Vestnik Atomproma, October, pp.30-33

Segodnya (1994) "Provintsial'naya khronika [The provincial chronicle]", Segodnya, 9 August

Segodnya (1995a) "El'tsin otmenyaet zalogovye auktsiony po aktsiyam 8 strategicheskikh predpriyatii [El'tsin revokes collateral auctions for shares of 8 strategic enterprises]", Segodnya, 9 December

Segodnya (1995b) "El'tsin utverzhdaet spisok predpriyatii, aktsii kotorykh peredayutsya v zalog bankam [El'tsin confirms list of enterprises whose shares will be transferred to banks as collateral]", Segodnya, 27 September 1995

Sergeev, M. (2007a) "Rossiyu ottesnyayut ot kazakhstanskogo urana [Russia is being pushed out of Kazakhstani uranium]”, Nezavisimaya gazeta, 10 July, p.1

Sergeev, M. (2007b) "Kiev ishchet zamenu Rosatomu [Kiev looks for a substitute for Rosatom]", Nezavisimaya gazeta, 20 July, p.1

Sergeev, N. and Sokovnin, A. (2011) "Den'gi Evgeniya Adamova priznany chistymi [Evgenii Adamov's money are found to be clean]", Kommersant, 28 September, p.4 Serov, A. (1997) "Megadollary [Megadollars]", Itogi, 5 May 
Shmidke, A. (2006) “Atomnaya promyshlennost' Kazakhstana: Sovremennoe sostoyanie i perspektivy razvitiya [Kazakhstan's nuclear industry: current situation and development perspectives]", Resursy po stranam - Tsentral'naya Aziya - Analiz

Shtaltovnyi, O. (2011) "Rosiya zberezhe monopoliyu na yaderne palyvo [Russia retains the monopoly on nuclear fuel]" [online]. 7 October (Kyiv: BBC Ukrainian). Available from: http://www.bbc.co.uk/ukrainian/news/2011/10/111007_russia_nuclear_it. shtml [Accessed 1 July 2019]

Sidorenko, V.A. (1997) "Nuclear power in the Soviet Union and in Russia", Nuclear Engineering and Design, 173: 3-20

Siluyanova, P. and Kovalevskii, A. (2004) "Stop, kadr. Atomnyi prikhod [Freeze. A nuclear appointment]", Gazeta, 25 October, p.9

Sindelar, D. (2006) "Russia: Moscow seeks to reignite nuclear power industry" [online]. 14 February Radio Free Europe/Radio Liberty). Available from: http://www.rferl. org/content/article/1065754.html [Accessed 1 July 2019]

Skorlygina, N. (2012) “'Rosenergoatom' stal ubytochnym [Rosenergoatom at a loss]”, Kommersant, 12 March, p.11

Slivyak, V. et al. (2010) Mify ob atomnoi energii. Pochemu razvitie atomnoi energii vedet nas $v$ tupik [Myths on atomic power. Why the development of atomic energy leads us down a cul-de-sac]. (Moscow: Heinrich Böll Stiftung)

Sokovnin, A. (2008) "Devyat' let odnogo dela [One case for nine years]", Kommersant, 25 January, p. 5

Sotnik, A. (2001) "Ekonomika. Atom tyanetsya k alyuminii [Economy. The nuclear sector extends to aluminium]", Moskovskie novosti, 10 April

Starostin, A. (2003) "Troistvennyi' yadernyi soyuz v deistvii [The 'triple' nuclear union in action]", Delovaya stolitsa, 12 May

Stenin, A. (2005) "Peretyagivanie Adamova [The tug-of-war for Adamov]", Gazeta.ru, 19 May

Stulberg, A.N. (2007) Well-oiled Diplomacy. Strategic Manipulation and Russia's Energy Statecraft in Eurasia (Albany, New York: State University of New York Press)

Stulberg, A.N. and Fuhrmann, M. (2013) "Introduction: Understanding the nuclear renaissance", in Stulberg, A.N. and Fuhrmann, M. eds, The Nuclear Renaissance and International Security (Stanford: Stanford Security Studies/Stanford University Press), pp.1-16

The Moscow Times (2012) "Ex-Rosatom deputy head granted $\$ 160,000$ bail", The Moscow Times, 13 November

Thomas, S. (2018) "Russia's nuclear export programme", Energy Policy, 121: 236-247

Torbakov, I. (2006) "Russia welcomes Uzbekistan into its Eurasian energy empire", Eurasia Daily Monitor, 27 January

Tovkailo, M. (2007) "Sergei Kirienko raskolol yadro atoma [Sergei Kirienko splits the atomic nucleus]", Gazeta, 13 December, p.13

Treisman, D. (2010) “Loans for shares' revisited”, Post-Soviet Affairs, 26 (3): 207-227

Turanov, S. (2004) "Rukovoditeli gosudarstvennykh bankov ukreplyayut svoi pozitsii", Ekonomika i zhizn', 24 July, p.21

UNIAN (2011) "TEO zavoda po proizvodstvu yadernogo topliva v Ukraine gotovo na $80 \%$ [The feasibility study for a nuclear fuel factory in Ukraine is $80 \%$ ready]" [online]. 14 September (Kyiv: UNIAN News Agency). Available from: http://energy. unian.net/oilandgas/542093-teo-zavoda-po-proizvodstvu-yadernogo-topliva-v-ukrainegotovo-na-80.html [Accessed 1 July 2019] 
Uranium One Group (2018) "Uranium One: About us" [online]. (Toronto: Uranium One Group,). Available from: http://www.uranium1.com/about-us/\#history [Accessed 13 November 2018]

Vaganov, A. (1998) "Smena rukovodstva Minatoma [Leadership succession in Minatom]", Nezavisimaya gazeta, 3 March, p.1

Vaganov, A. (1999) "Ukraina ssorit'sya s Rossiei nevygodno [Ukraine stands to lose from quarreling with Russia]", Nezavisimaya gazeta, 11 November

Vaganov, A. (2005) "Rosenergoatom" aktsioniruyetsya. Atomnaia energetika zhazhdaet kreditov, investitsii i drugikh atributov rynka [Rosenergoatom is being incorporated. The atomic energy industry thirsts for credits, investment and other market attributes]", Nezavisimaya gazeta, 19 September, p.1

Vaganov, A. (2006) "Atomnuyu energetiku privatiziruyut. No Atomprom budet stoprotsentno gosudarstvennym, uveryayut $\mathrm{v}$ Rosatome [The atomic energy industry is being privatised. But Atomprom will be $100 \%$ state owned, Rosatom assures]", Nezavisimaya gazeta, 10 February, p.3

Vakarelska, R. (2017) "Ukraine's power game" [online]. 2 February Nuclear Engineering International). Available from: https://www.neimagazine.com/features/featur eukraines-power-game-5730089/ [Accessed 20 November 2018]

Vakhmenin, A. (2007) "Koloss na atomnykh nogakh [A colossus with atomic feet]", Moskovskie novosti, 21 December

Varaksin, D. (2009) "Uranovyi obmen [Uranium exchange]", Vedomosti, 16 June

Vinokurov, E. (2007) "Perspektivy integratsii atomno-energeticheskikh kompleksov Rossii i Kazakhstana [Perspectives for integration between Russia's and Kazakhstan's nuclear energy complexes]" [online]. 15 June Proatom.ru). Available from: http://www. proatom.ru/modules.php?name $=$ News\&file $=$ article $\&$ sid= $=1014$ [Accessed 1 July 2019]

Volchko, D. (1998) "Minatom spokoen [Minatom is calm]", Russkii Telegraf, 4 March Voloshin, G. (2015) "India covets comprehensive reengagement with Central Asia", Eurasia Daily Monitor, 28 July

Voskresenskii, G. (2000) "Yadernyi poluraspad integratsionnogo protsessa. Diktuet li logika razvitiya atomnoi energetiki svoi zakony politikam [The integration process's nuclear semi-collapse. Do nuclear energy development logics set their own laws to the politicians]", Vek, 3 November, p.8

Weitz, R. and Choi, D. (2014) "Seoul seeks Central Asian partners", Eurasia Daily Monitor, 14 July

WNA (2008) "Nuclear power in Russia" [online]. August (London: World Nuclear Association). Available from: http://world-nuclear.org/info/inf45.html [Accessed 27 August 2008]

WNA (2011a) "Uranium and Nuclear Power in Kazakhstan" [online]. 1 October 2011 (London: World Nuclear Assosiation). Available from: http://www.world-nuclear. org/info/Country-Profiles/Countries-G-N/Kazakhstan/ [Accessed 7 October 2011]

WNA (2011b) "Russia's nuclear fuel cycle" [online]. 2 September 2011 (London: World Nuclear Association). Available from: http://www.world-nuclear.org/info/ inf45a_Russia_nuclear_fuel_cycle.html [Accessed 10 December 2011]

WNA (2015) "Nuclear power in Russia” [online]. January 2015 (London: World Nuclear Association). Available from: http://world-nuclear.org/info/Country-Profiles/Coun tries-O-S/Russia-Nuclear-Power/ [Accessed 13 February 2015]

WNA (2018a) "Uranium in Uzbekistan" [online]. October World Nuclear Association). Available from: http://www.world-nuclear.org/information-library/country-p rofiles/countries-t-z/uzbekistan.aspx [Accessed 9 November 2018] 
WNA (2018b) "Nuclear power in Russia" [online]. October (London: World Nuclear Association). Available from: http://www.world-nuclear.org/information-library/coun try-profiles/countries-o-s/russia-nuclear-power.aspx [Accessed 28 November 2018]

WNA (2018c) "Nuclear power in Ukraine" [online]. August World Nuclear Association). Available from: http://www.world-nuclear.org/information-library/country-p rofiles/countries-t-z/ukraine.aspx [Accessed 16 November 2018]

WNA (2018d) "Nuclear power in Armenia" [online]. March (London: World Nuclear Association). Available from: http://www.world-nuclear.org/information-library/ country-profiles/countries-a-f/armenia.aspx [Accessed 9 November 2018]

WNA (2018e) "Russia's nuclear fuel cycle" [online]. May (London: World Nuclear Association). Available from: http://www.world-nuclear.org/information-library/coun try-profiles/countries-o-s/russia-nuclear-fuel-cycle.aspx [Accessed 7 November 2018]

WNA (2018f) "Nuclear power in Belarus" [online]. June World Nuclear Association). Available from: http://www.world-nuclear.org/information-library/country-profiles/ countries-a-f/belarus.aspx [Accessed 8 November 2018]

Yamshchikov, S. et al. (1998) "Yadernyi eksport: period poluraspada [Nuclear export: the semi-collapse period]", Obshchaya gazeta, 24 December

Yermukanov, M. (2006) "Astana opts for Russian assistance in nuclear energy development”, Eurasia Daily Monitor, 8 November

Yur'eva, E. (2007) "Rossiya vklyuchilas' v uranovuyu gonku [Russia joins the uranium race]", Ekspert, 8 October, pp.30-36

Zamyatin, V. (1996) "Tender na stroitel'stve zavoda [A tender to construct a factory]", Kommersant, 7 February, p.17

Zotova, I. (1992) "Dzhokhar Dudaev i Ruslan Utsiev zaklyuchili ekonomicheskii soyuz [Dzhokhar Dudaev and Ruslan Utsiev enter into economic union]", Kommersant, 6 January

Afanasiev, V. (2011) "Lukoil to broaden horizons" Upstream, 28 October, p.37

Alekperov, V. (2000) "My slishkom dolgo zapryagali? [Did we prepare for too long?]" Izvestiya, 8 June

Alekperov, V. (2003) "Preimushchestva konkurentsii. Demonopolizatsiya neftyanogo sektora prevratila resursnyi potentsial Rossii v lokomotiv ee ekonomicheskogo razvitiya [The advantages of competition. The de-monopolization of the oil sector turned Russia's resource potential into a locomotive for its economic development]" Izvestiya, 7 March, p. 6

Alekperov, V. (2006) Vystuplenie V.Yu. Alekperova na sobranii aktsionerov [V.Yu. Alekperov's speech at the annual general meeting] (Moscow: Lukoil)

Alekperov, V. (2009) Vystuplenie prezidenta OAO "Lukoil" V.Yu. Alekperova na evropeiskom biznes sammite, Bryussel' [Speech of Lukoil's president, V. Yu. Alekperov, at the European Business Summit, Brussels] (Moscow: Lukoil)

Alekperov, V. (2011a) Oil of Russia. Past, Present \& Future (Minneapolis: East View Press) Alekperov, V. (2011b) "Bazis integratsii [The basis of integration]" Izvestiya, 18 November, p.1

Aleksandrovich, S. (2000) "'Lukoil' formiruet novuyu rossiiskuyu politiku na Kaspii [Lukoil forms the new Russian policy in the Caspian]" Neft' $i$ Kapital, April 2000

Aleksandrovich, S. (2001) "Moskva-Baku: soobshchenie vozobnovlyaetsya [MoscowBaku: contact is renewed]" Neft' $i$ Kapital, January

Aleksashenko, S. (2012) "Russia's economic agenda to 2020", International Affairs, 88 (1): $31-48$ 
Analiticheskii Tsentr (2015) Inertsiya elektroenergetiki [The inertia of electricity]. Energeticheskii byulleten'. (Moscow: Analiticheskii Tsentr pri Pravitel'stve Rossiiskoi Federatsii/Analytical Center for the Government of the Russian Federation)

Anokhin, K. (2017) "Produktivnaya energodiplomatiya [Productive energy diplomacy]" Neftegazovaya vertikal', Nos 1-2, pp.30-33

APEK (2017) "Reiting vliyaniya krupnykh predprinimatelei $i$ top-menedzherov toplivnoenergeticheskogo kompleksa $v$ iyune $2017 \mathrm{~g}$. [Rating of the influence of major businessmen and top managers in the fuel and energy complex, June 2017]" [online]. 29 June 2017 (Moscow: Agentstvo politicheskikh i ekonomicheskikh kommunikatsii). Available from: http://apecom.ru/projects/item.php?SECTION_ID=102\&ELEMENT_ID= 3803 [Accessed 18 March 2019]

Astakhova, O. and Basvain, D. (2011) "LUKOIL zhdet rosta dobychi posle $2012 \mathrm{~g}$., zhazhdet rabotat' v RF [Lukoil expects a rise in production after 2012, is longing to work in Russia]" Reuters, 31 August

Babaeva, S. (2001) "Vagit Alekperov: Neftyanaya otrasl' vyzdorovela [Vagit Alekperov: The oil sector has recovered]" Izvestiya, 28 June, p.1

Balmaceda, M.M. (2008) Energy Dependency, Politics, and Corruption in the Former Soviet Union. Russia's Power, Oligarchs' Profits and Ukraine's Missing Energy Policy, 1995-2006 (London/New York: Routledge)

Barber, L. and Foy, H. (2017) "Lukoil chief says sanctions may last a decade" The Financial Times, 12 October

Barsukov, Yu. (2012) "FAS predlagaet otkryt' shel'f [FAS proposes to open the shelf]" Kommersant, 2 August, p.7

Barsukov, Yu. (2017) "Neftyanikov zapirayut v Rossii [The oilmen are locked in Russia]" Kommersant, 1 November

Blagov, S. (2006) "Russia renews diplomatic-economic offensive" Eurasianet.org, 18 April

Boiko, B. (1999) "Eksport ob"yavlen politicheski vrednym [Export is announced to be politically harmful]" Kommersant, 30 July 1999, p.7

Bolshoi biznes (2003) Interv'yu V. Yu Alekperova zhurnalu Bolshoi Biznes, noyabr' 2003 goda [Interview by V. Yu. Alekperov to Bolshoi Biznes magazine, November 2003] (Moscow: Lukoil)

Bolukbasi, S. (1998) "The controversy over the Caspian Sea mineral resources: Conflicting perception, clashing interests”, Europe-Asia Studies, 50 (3): 397-414

Bradshaw, M. (2009) "The Kremlin, national champions and the international oil companies: The political economy of the Russian oil and gas industry", Geopolitics of Energy, 31 (5): 2-14

Bradshaw, M. (2012) "Russian energy dilemmas: Energy security, globalization and climate change" in Aalto, P. ed., Russia's Energy Policies. National, Interregional and Global Levels (Cheltenham: Edward Elgar), pp.206-229

Bugriy, M. (2016) "Russia's moves to gain dominance in the Black Sea" Eurasia Daily Monitor, 17 February

Burchilina, T. (1995) "Situatsiya vokrug Tengizskogo mestorozhdeniya. Za odnogo bitogo predlozhili dvukh nebitykh [The situation around the Tengiz deposit.Two unconquered ones proposed to replace one vanquished]" Kommersant, 15 November 1995, p.9

Butrin, D. (2001) "Baku-Dzheikhan dotyanetsya do Rossii [Baku-Ceyhan reaches into Russia]" Kommersant, 24 November, p.4 
Butrin, D. (2003) “"Na yuge Evropy nas interesuet vse' ['In southern Europe, everything interests us']" Kommersant, 8 September 2003, p.1

Butrin, D. (2004) "Gazprom menyaet Yamal na Uzbekistan [Gazprom exchanges Yamal for Uzbekistan]" Kommersant, 16 April 2004, p.16

Cockburn, P. (1994) "Russia and US in tussle over oil in Caspian" The Independent, 3 November 1994, p.14

Connolly, R. (2018) Russia's Response to Sanctions (Cambridge: Cambridge University Press)

Daly, J.C.K. (2014) "Russian oil to feature in Baku-Tbilisi-Ceyhan Pipeline: Circumventing possible sanctions?" Eurasia Daily Monitor, 30 May

Davydov, A. (1996) "Novoe soglashenie LUKOILa. Dazhe uidya iz politiki, ne izbezhat' vstrech s politikami [Lukoil's new agreement. Even when you leave politics, it's difficult to avoid meeting politicians]" Kommersant, 6 July 1996, p.9

Decree No. 327 (01/04/1995) O pervoocherednykh merakh po sovershenstvovaniyu deyatel'nosti neftyanykh kompanii [On first measures to perfect the operations of oil companies] (Moscow: President of the Russian Federation)

Decree No. 1403 (17/11/1992) Ob osobennostyakh privatizatsii $i$ preobrazovaniya $v$ aktsionernye obshchestva gosudarstvennykh predpriyatii, proizvodstvennykh i nauchnoproizvodstvennykh ob"edinenii neftyanoi, neftepererabatyvayushchei promyshlennosti $i$ nefteproduktoobespecheniya [On the specificities of privatisation and conversion into shareholding companies of enterprises, production and scientific production associations in the oil and oil refinery industries and oil product distribution] (Moscow: President of the Russian Federation)

Derbilova, E. and Mazneva, E. (2011) “'Moya lyubov' na vsyu zhizn' - eto neft' ['Oil is the love of my life']" Vedomosti, 22 December 2011, p.5

Drankina, E. and Fadeev, V. (2001) "Formula nefti [The oil formula]" Ekspert, 16 April 2001, pp.22-27

Dzyadko, T. and Podobedova, L. (2016) "'Bashneft" v odni ruki [Bashneft in the same hands]" RBK Daily, 7 October, p.1

Easter, G.M. (2012) Capital, Coercion, and Postcommunist States (Ithaca/London: Cornell University Press)

Egorova, T. (2004) "Vse v Baku-Dzheikhan [Everyone to Baku-Ceyhan]" Vedomosti, 18 March

Ekonomika i zhizn' (2009) "Nulevaya stavka NDPI dlya nefti [A zero mineral extraction tax for oil]" Ekonomika i zhizn', 9 October 2009, p.8

Embassy Moscow (2006) Russian oil to Lithuania - Mixing revenge and business, 06MOSCOW9482/Wikileaks \#76658. Issue date 30 August 2006 [online]. (Published by Wikileaks 8 September 2011). Available from: https://wikileaks.org/plusd/ cables/06MOSCOW9482_a.html [Accessed 13 February 2019]

Embassy Vilnius (2005a) Adamkus upset about Conocophillips-lukoil bid on the Baltics' only oil refinery, Issue date 23 September 2005 [online]. (Published by Wikileaks 1 September 2011). Available from: https://wikileaks.org/plusd/cables/05VILNIUS1007_a. html [Accessed 13 February 2019]

Embassy Vilnius (2005b) Conocophillips set to request Usg advocacy on bid with Lukoil for refinery, 05VILNIUS1186/Wikileaks \#44450. Issue date 4 November 2005 [online]. (Published by Wikileaks 1 September 2011). Available from: https:// wikileaks.org/plusd/cables/05VILNIUS1186_a.html [Accessed 13 February 2019]

Embassy Vilnius (2006) Two Russian oil suppliers cancel July crude shipments to Lithuanian refinery, 06VILNIUS618/Wikileaks \#70128. Issue date 3 July 2006 
[online]. (Published by Wikileaks 1 September 2011). Available from: https://wikilea ks.org/plusd/cables/06VILNIUS618_a.html [Accessed 13 February 2019]

Eremenko, A. (2011) "Energorynok: 20 let (ne) zavisimosti [The energy market: 20 years of (in) dependence]" Zerkalo nedeli, 26 August

Federal Law No. 2395 (21/02/1992) O nedrakh [On the subsoil] (Moscow: The Federal Assembly)

Finam (2010) “"Natsional'nyi neftyanoi konsortsium”” mozhet investirovat' \$900 mln v razrabotku bloka Khunin-6 v Venesuele [The National Oil Consortium may invest $\$ 900$ million in the development of the Junin-6 block in Venezuela]" [online]. 26 January 2010 (Moscow: Finam). Available from: http://www.finam.ru/analysis/news item45C28/default.asp [Accessed 13 February 2019]

Firsova, A. (2005) "Edinaya skvazhina dlya investora [A unified borehole for investors]" Finam.ru, 30 March

Fortescue, S. (2006) Russia's Oil Barons and Metal Magnates. Oligarchs and the State in Transition (Basingstoke/New York: Palgrave Macmillan)

Fortescue, S. (2009) "The Russian law on subsurface resources: A policy marathon", Post-Soviet Affairs, 25 (2): 160-184

Fuller, L. (1995) "Azerbaijan: The "Near Abroad" Transitions Online, 28 April

Gavrish, O. (2005) "Viktor Yushchenko preodolel benzinovyi krizis [Viktor Yushchenko overcomes the petrol crisis]" Kommersant, 21 May 2005, p.5

Gavrish, O. (2006) "Vlasti Ukrainy zastavili neftyanikov samoogranichit'sya [Ukraine's powers forces the oilmen to restrain themselves]" Kommersant, 15 August 2006, p. 10

Gavrish, O. and Lysova, T. (1999) "Nesamostiinyi benzin [Dependent petrol]" Ekspert, 26 July

Gavrish, O. and Chernovalov, A. (2005) “'Lukoil-Neftekhim” zanes v 'Lukor' den'gi vmesto aktsii [Lukoil-Neftekhim contributes money instead of shares to Lukor]" Kommersant, 5 December 2005, p.15

Germanovich, A. (2000) "Trebuetsya novoe slovo [A new word is needed]" Vedomosti, 31 July

Glumskov, D. and Skorobogat'ko, D. (2003) "LUKOIL ne zhaleet deneg na Kazakhstan [Lukoil does not spare any money in Kazakhstan]" Kommersant, 14 October 2003, p.13

Golubkova, E. and Ershov, A. (2010) 'Interv'yu prezidenta OAO 'Lukoil' V.Yu. Alekperova agentstvu Reiter [Interview with Lukoil president V.Yu. Alekperov by Reuters agency]" Reuters, 31 August 2010

Golubkova, E., Sapozhnikov, P. and Lyrchikova, A. (2007) "Nam komfortno v proektakh s goskapitalom', - Vagit Alekperov [Vagit Alekperov: 'We are comfortable in projects with state capital']" $R B C$ Daily, 26 February

Gorelov, N. (2001) "Ukrainskie stradaniya. LUKOILu razreshili postavlyat' v Odessu malo nefti [Ukrainian sufferings. Lukoil is allowed to supply little oil to Odesa]" Vremya novostei, 27 September 2001, p.4

Gorshkova, A. (2007) "Kompromiss dlya kitaitsev [A compromise for the Chinese]" Vremya novostei, 13 September 2007, p.8

Gorst, I. (2007) Lukoil: Russia's Largest Oil Company (Houston: The James A. Baker III Institute for Public Policy, Rice University)

Gotova, N. (2004) "Plov i vyshka [Pilau and derrick]" Profil', 21 June 2004, pp.30-32

Government Order No. 18 (25/11/1991) Ob obrazovanii neftyanogo kontserna "LANGEPASURAIKOGALYMNEFT", ("LUKOIL") [On the creation of the oil concern 
"LANGEPASURAIKOGALYMNEFT"” (LUKOIL) (Moscow: The Government of the RSFSR (Russian Soviet Federative Socialist Republic))

Graifer, V.I. (2005) Vystuplenie V.I. Graifera na s"ezde gornopromyshlennikov [V.I. Graifer's speech at the Miners' Convention] (Moscow: Lukoil)

Granik, I. and Gabuev, A. (2009) "Rossiiskii gaz rasshirilsya do Ispanii [Russian gas has been extended to Spain]" Kommersant, 4 March 2009, p.6

Grib, N. and Mel'nikov, K. (2010) "LUKOIL pustit gaz v Kitai [Lukoil sends gas to China]" Kommersant, 20 September 2010, p.9

Grivach, A. (2009) "Berkut-shou v 'Ukrtransnafte' [Golden eagle show in Ukrtransnafta]" Vremya novostei, 23 June 2009, p.8

Gudkov, A. (2010) "LUKOIL pognalsya za 'Rosneft'yu' [Lukoil ran after Rosneft]" Kommersant, 9 November 2010, p.6

Gustafson, T. (2012) Wheel of Fortune. The Battle for Oil and Power in Russia (Cambridge, MA/London: The Belknap Press of Harvard University Press)

Heath, J.R. (2009) "Strategic protectionism? National Security and Foreign Investment in the Russian Federation", George Washington International Law Review, 41 (2009): 101-137

Heil, A. (2008) "5 + $2=42$ million" [online]. Posted to the blog 'Transmission' on 22 July. Available from: http://www.rferl.org/content/Moldova/1185425.html [Accessed 13 June 2019]

Hilyard, J.F. (2012) The Oil \& Gas Industry. A Nontechnical Guide (Tulsa: PennWell)

Ignatova, M. (2003) "Leonid Fedun, vitse-prezident 'LUKOILa': Ideya pobol'she obobrat' neftyanikov segodnya uspeshno realizuetsya [Leonid Fedun, Lukoil's vice president: The idea of grabbing the oil sector as much as possible is being implemented]" Finansovye Izvestiya, 10 October 2003, p.5

Igorev, A. et al. (2000) "Prishli za Alekperovym [They came for Alekperov]" Kommersant, 12 July 2000, p.1

Interfaks-ANI (2011) "Ya ne veryu v \$200 za barrel', no i ne veryu v \$50 [I don't believe in \$200 a barrel, but neither do I believe in \$50]" Interfaks-ANI, 18 November 2011

Interfax (2001) "Lukoil requires more information to purchase Hellenic shares" Interfax Business Report, 2 November

Ivanov, A. (1997) 'Pekin perekhvatil u LUKOILa kazakhskuyu neft' [Beijing intercepts Kazakh oil from Lukoil]" Kommersant, 7 October 1997, p.2

Ivanov, N. (1999) "Svoi chelovek v Mintope [One of our own in the Fuel and Energy Ministry]" Segodnya, 26 May

Jensen, D. (2000) "End Note: Putin to meet oligarchs" Radio Free Europe/Radio Liberty Newsline, 28 July

Kazakhstan Business Magazine (2004) "Kazakhstan's oil sector: Events and facts" Kazakhstan Business Magazine, 38 (1). Available from: http://www.investkz.com/en/ journals/38/159.html [Accessed 5 April 2020]

Kezik, I. (2007) "Lukoil i 'Rosneft" podelili kitaiskuyu druzhbu [Lukoil and Rosneft share Chinese friendship]" Gazeta, 11 September 2007, p.9

Khartukov, E. (2000) "Russia's oil privatization is more greed than fear" Oil \& Gas Journal, 3 July 2000, p.30

Khnychkin, Yu. (1992) "Na neftyanom nebosklone Rossii voskhodit zvezda 'Luk oil' [Luk oil rises on Russia's oil horizon]" Kommersant, 13 July

Khodasevich, A. (2010) "Lukashenko obeshchaet novuyu privatizatsiyu [Lukashenka promises a new privatisation]" Nezavisimaya gazeta, 13 April 2010, p.6 
Kim, A. (2014) "Political scandal in Uzbekistan harms investment climate" Eurasia Daily Monitor, 3 February

Kommersant-Vlast' (2002) "Prem'er v sostoyanii voiny [The premier in a state of war]" Kommersant-Vlast', 28 May, p.9

Kommersant (1996) “'YUKOS' i 'LUKOIL' priobretut sobstvennost' v Litve [Yukos and Lukoil acquire equity in Lithuania]" Kommersant, 13 November 1996, p.8

Kommersant (2002) "Chem vladeyut rossiiskie kompanii na Ukraine [What Russian companies own in Ukraine]" Kommersant, 21 December, p.1

Kommersant (2004a) "Statistika vstrech prezidenta s oligarkhami [Statistics of the president's meetings with the oligarchs]" Kommersant, 2 July 2004, p.2

Kommersant (2004b) "Prezident LUKOILa vstretilsya s prezidentom Ukrainy [Lukoil's president meets Ukraine's president]" Kommersant, 22 October 2004, p.16

Kommersant (2004c) "Kak sozdavalsya LUKOIL [How Lukoil was formed]" Kommersant, 23 July, p.6

Kommersant (2005) "Kto chashche vsekh poseshchal prezidenta [Who visited the president most often]" Kommersant, 25 March 2005, p.1

Kommersant (2006) "Segodnya [Today]" Kommersant, 11 January, p.5

Kommersant (2008) "Nashi blagie namereniya chasto razbivayutsya o kharakter administrirovaniya" ['Our good intentions are often crushed against the nature of administration']" Kommersant, 24 January 2008, p.20

Konoplyanik, A. (2001) "Povyshenie denezhnogo davleniya. Nalogovaya reforma v neftyanoi otrasli: pervye rezul'taty [Increased pressure for money. The tax reform in the oil sector: first results]" Izvestiya, 21 November 2001, p.7

Kozlov, D., Barsukov, Yu. and Butrin, D. (2016) "Neft' bez chastnykh primesei [Oil without private additives]" Kommersant, 3 October, p.1

Krasovskaya, E. (2017) "LUKOIL vypolnit reshenie OPEK o prolongatsii sokrashcheniya neftedobychi [Lukoil will fulfil OPEC's decision on prolonged production cuts]" [online]. 25 May (Moscow: IG Industriya). Available from: https://oilcapital.ru/news/ companies/25-05-2017/lukoyl-vypolnit-reshenie-opek-o-prolongatsii-sokrascheniya-nef tedobychi [Accessed 21 March 2019]

Kravets, M. (2004) "Pol'za ot udvoeniya VVP [The utility of doubling the GDP]" Neftegazovaya vertikal', No. 2, 9 February

Krivorotov, A. (1998) "Delit'sya budem bystro, no chestno [We will divide quickly, but honestly]" Neft' i Kapital, May 1998

Kudinov, I. (2016) "Kurchenko zazhil 'po-novomu' [Kurchenko started a 'new life']" Nefterynok, 29 June

Kupfer, M. and Jardine, B. (2016) "Russia's Bashneft: A very public privatization" The Moscow Times, 5 October

Levinskii, R. (2004) "Tsepnaya reaktsiya [Chain reaction]" Vedomosti, 21 December

Lowe, C. and Sagdiev, R. (2019) "How Russia sank billions of dollars into Venezuelan quicksand" [online]. 14 March (London: Reuters). Available from: https://www.reuters. com/investigates/special-report/venezuela-russia-rosneft/ [Accessed 14 March 2019]

Lukin, O. (2006) "Tashkent zastavit potesnit'sya [Tashkent forces them closer together]" Neftegazovaya vertikal', No. 4, 21 March

Lukin, O. (2007) "Vybor strategii opredelit budushchee TEK Rossii [The choice of strategy decides the future of Russia's energy industry]" Neftegazovaya vertikal', No. 1, 20 January

Lukin, O. (2010a) "Bog dal, Bog vzyal [The Lord giveth and the Lord taketh away]" Neftegazovaya vertikal', No. 8, pp.79-81 
Lukin, O. (2010b) "Ostorozhno, dveri zakryvayutsya [Please mind the closing doors]" Neftegazovaya vertikal', No. 18, pp.62-64

Lukin, O. (2012) "Tsentral'naya Aziya: Usilenie gazovoi konkurentsii [Central Asia: The gas competition strengthens]" Neftegazovaya vertikal', No. 9, pp.18-20

Lukoil-Trans (2014) "OOO 'Varandeiskii terminal' [The Varandei Terminal]" [online]. (Moscow: Lukoil). Available from: http://rans.lukoil.ru/ru/About/Structure/Vara ndeyTerminal [Accessed 1 July 2019]

Lukoil - PJSC "Lukoil” (2019) "Oil Company Lukoil” [online]. (Moscow: Lukoil). Available from: http://www.lukoil.com/ [Accessed 21 February 2019]

Lukoil (2000) Neftyanaya kompaniya Lukoil. Godovoi otchet 1999 [Oil company Lukoil. Annual report 1999] (Moscow: Lukoil)

Lukoil (2001) Lukoil. Neftyanaya kompaniya. Godovoi otchet 2000 [Lukoil, oil company. Annual report 2000] (Moscow: Lukoil)

Lukoil (2003) Neftyanaya kompaniya Lukoil. Otchet o deyatel'nosti 2002 [Oil company Lukoil. Annual report 2002] (Moscow: Lukoil)

Lukoil (2004) Lukoil. Otchet o deyatel'nosti kompanii v 2003 godu [Lukoil. Annual report for 2003] (Moscow: Lukoil)

Lukoil (2007) Lukoil. Otchet o deyatel'nosti 2006 [Lukoil. Annual report 2006] (Moscow: Lukoil)

Lukoil (2015) OAO Lukoil. Annual report 2014 (Moscow: Lukoil)

Lukoil (2016) Lukoil. Always moving forward. Annual report 2015 (Moscow: Lukoil)

Lukoil (2017) Lukoil. The sea of opportunities. Annual report 2016 (Moscow: Lukoil)

Lukoil (2018a) Lukoil. Unlocking the potential. Annual report 2017 (Moscow: Lukoil)

Lukoil (2018b) Lukoil otkryl pervuyu AZS v Uzbekistane [Lukoil opens first petrol station in Uzbekistan] (Moscow: Lukoil)

Lukoil (2018c) Lukoil commissions gas processing complex in Uzbekistan ahead of schedule (Moscow: Lukoil)

Lukoil Overseas Holding Ltd. (2005) Korporativnyi otchet 2004 [Corporate report 2004] (Moscow: Lukoil Overseas)

Lukoil Overseas Holding Ltd. (2011) Korporativnyi otchet 2010 [Corporate report 2010] (Moscow: Lukoil Overseas)

Luong, P.J. and Weinthal, E. (2004) "Contra coercion: Russian tax reform, exogenous shocks, and negotiated institutional change", American Political Science Review, 98 (1): 139-152

Lyapunova, G. (2001) "Deputaty ukhodyat v nedra [Deputies go to the subsoil]" Kommersant, 7 June 2001, p.1

Lysova, T. (1999) "Lukoilu 'nuzhny ne aktsii, a den'gi' [Lukoil does not need shares, but money]" Vedomosti, 13 September

Makarkin, A. (2005a) "Revolyutsiya i proza zhizni [Revolution and the prose of life]" Neft' $i$ Kapital, October

Makarkin, A. (2005b) "Ukraina pri Viktore Yushchenko i interesy rossiiskogo TEK [Ukraine under Viktor Yushchenko and the interests of the Russian energy complex]" Neft' i Kapital, January-February

Makarkin, A. (2008a) "V Tashkente vse stabil'no [In Tashkent, all is stable]" Neft' $i$ Kapital, May

Makarkin, A. (2008b) "Vosem' let prezidenta Putina [Eight years of President Putin]" Neft' i Kapital, April

Malkova, I. (2010) “Otkryt' shel'f [Opening up the shelf]" Vedomosti, 31 March 
Mandrik, I. (2011) “OAO 'LUKOIL': problemy razvitiya mineral'no-syr'evoi bazy [Lukoil: the problems of development of its mineral and raw materials base]" Neftegazovaya vertikal', 5, pp.40-44

Marten, K. (2007) "Russian efforts to control Kazakhstan's oil: The Kumkol case", Post-Soviet Affairs, 23 (1): 18-37

Mazneva, E. (2008) "Daite otsrochku [Give a deferment, please]" Vedomosti, 1 November

Mazneva, E. (2011) "Kazakhskaya arifmetika [Kazakh arithmetics]" Vedomosti, 16 December, p.7

Mazneva, E., Zhelobanov, D. and Tutushkin, A. (2008) "Net pokupatelei i adekvatnoi tseny' - Leonid Fedun sovladelets 'Lukoila', IFD 'Kapital', FK 'SpartakMoskva' [No buyers and no adequate price - Leonid Fedun, co-owner of Lukoil, Kapital and Spartak-Moscow]" Vedomosti, 18 December

Mel'nikov, K. (2010) "Plata za spokoistvie [A charge for peace of mind]" Vremya novostei, 4 June 2010, p.8

Mel'nikov, K. (2011) “'Rebyata, my vozvrashchaemsya v Sovetskii Soyuz, u nas reguliruemaya tsena na benzin' ['Guys, we're returning to the Soviet Union, the petrol price is regulated']" Kommersant, 14 April 2011, p.14

Mel'nikov, K. (2015) "Arkticheski reshennyi vopros [An Arctically decided question]" Kommersant, 26 March, p.1

Meshcherin, A. (2010) "Energeticheskii duumvirat [The energy duumvirate]" Neftegazovaya vertikal', 13-14, pp.16-23

Meshcherin, A. (2011a) "Dividendy: eto vam ne el'dorado [Dividends: no Eldorado]" Neftegazovaya vertikal', 15-16, pp.32-37

Meshcherin, A. (2011b) "Oglushitel'nyi prirost zapasov [A deafening growth in reserves]" Neftegazovaya vertikal', 2, pp.12-15

Meshcherin, A. (2011c) "Fasadnoe blagopoluchie neft' i gaz Rossii 2010: predvaritel'nye itogi [Facade prosperity in Russian oil and gas in 2010: a preliminary summary]" Neftegazovaya vertikal', 4, pp.26-47

Ministry of Industry and Trade (2003) Energeticheskaya strategiya Rossii na period do 2020 goda [Russia's Energy Strategy for the period to 2020) (Moscow: Ministerstvo promyshlennosti i torgovli)

Mordyushenko, O. and Gavrish, O. (2009) "Neft' LUKOILa ostanovilas' v Odesse [Lukoil's oil stopped in Odesa]" Kommersant, 2 October 2009, p.11

Mordyushenko, O. and Barsukov, Yu. (2017) "Problemy strategicheskogo naznacheniya [Problems of strategic purpose]" Kommersant, 26 January, p.1

Moser, N. (2016) "Ownership and enterprise performance in the Russian oil industry, 1992-2012”, Post-Communist Economies, 28 (1): 72-86

Moskovskii Komsomolets (1998) "Non-stop. Politika. Berezovskii zaviduet Kuchme [Non-stop. Politics. Berezovskii envies Kuchma]" Moskovskii Komsomolets, 11 August

Narzikulov, R. (1997) “'Neft' - eto vsegda politika' ['Oil is always politics']” Nezavisimaya gazeta, 14 January 1997, p.1

Neft' $i$ Kapital (1999) 'Interv'yu V.Yu. Alekperova zhurnalu Neft' $i$ Kapital [Interview with V. Yu. Alekperov in Neft' $i$ Kapital magazine]" Neft' $i$ Kapital, November

Neft' i Kapital (2002a) 'Sebestoimost' - sokrashchat', eksport - narashchivat' [Reduce cost, increase export]" Neft' i Kapital, June

Neft' i Kapital (2002b) "'Lukoil Baltija R' gotova prodavat' toplivo v Evrope [Lukoil Baltija R is ready to sell fuel in Europe]" Neft' $i$ Kapital, September 
Neft' $i$ Kapital (2002c) "Tyazhelye razdumki pered reshitel'nym shagom [Difficult considerations before the decisive step]" Neft' $i$ Kapital, October

Neft' i Kapital (2002d) "Vagit Alekperov: 'My s optimizmom smotrim i na segodnyashnyuyu situatsiyu, i na dal'nyuyu perspektivu' [Vagit Alekperov: 'We're optimistic in our view of both the present situation, and when looking at the longer perspective']" Neft' $i$ Kapital, June

Neft' i Kapital (2003a) "'Famil'noe serebro' belorusskoi promyshlennosti [Belarusian industry's 'family silver']" Neft' $i$ Kapital, April

Neft' $i$ Kapital (2003b) "Rim Bagmanov: "Yalama - zadacha strategicheskaya" [Rim Bagmanov: 'Yalama is a strategic task']" Neft' $i$ Kapital, May

Neft' i Kapital (2004a) "Lakmusovaya bumazhka [Litmus paper]" Neft' $i$ Kapital, September

Neft' $i$ Kapital (2004b) "Tochka rosta [A point of growth]" Neft' $i$ Kapital, September

Neft' $i$ Kapital (2004c) "Ukrainskie NPZ [The Ukrainian refineries]" Neft' i Kapital, October

Neft' i Kapital (2004d) "Vagit Alekperov" Neft' i Kapital, October

Neft' $i$ Kapital (2004e) "Lukoil" Neft' i Kapital, October

Neft' i Kapital (2005a) "Ukrainskaya revolyutsia trebuet zhertv [The Ukrainian revolution claims victims]" Neft' i Kapital, May

Neft' $i$ Kapital (2005b) "Netraditsionnyi podkhod [An untraditional approach]" Neft' $i$ Kapital, December

Neft' $i$ Kapital (2006a) "Dvukhletnii taim-aut [A two-year time-out]" Neft' i Kapital, September

Neft' $i$ Kapital (2006b) "Pervomu - 15! [The first-born is 15!]" Neft' $i$ Kapital, November

Neft' $i$ Kapital (2006c) "Knutom i pryanikom [With stick and carrot]" Neft' i Kapital, September

Neft' i Kapital (2007a) "Rosneft" - samaya neftyanaya kompaniya [Rosneft, the oiliest company]" Neft' $i$ Kapital, May

Neft' $i$ Kapital (2007b) "Po vremennoi skheme [Temporary measures]" Neft' i Kapital, December

Neft' $i$ Kapital (2007c) "Ustupaya, nastupai [Advance while conceding]" Neft' i Kapital, December

Neft' $i$ Kapital (2007d) "Plody strategicheskogo al'yansa [The fruits of a strategic alliance]" Neft' $i$ Kapital, January-February

Neft' $i$ Kapital (2008) "LUKOIL' prinyal estafetu [Lukoil takes on the baton]" Neft' $i$ Kapital, May

Neft' i Kapital (2009) 'Kontekst. Gunvor konsolidiruet nefteperevalku v Ust'-Luge [Context. Gunvor is consolidating oil transhipment at Ust-Luga]" Neft' i Kapital, April

Neft' $i$ Kapital (2010) "Kak dym ot papirosy [Like smoke from a cigarette]" Neft' $i$ Kapital, March

Neft' $i$ Kapital (2011a) "Polimery bez polumer [Polymers without half measures]" Neft' i Kapital, October

Neft' i Kapital (2011b) "Uzbekskaya 'sinitsa' [The Uzbek 'bird']” Neft' i Kapital, July

Neft' i Kapital (2011c) "Chetyre pyatiletki 'LUKOILa"” [Lukoil's four five-year plans]" Neft' i Kapital, September

Neft' $i$ Kapital (2011d) 'Iz Tashkenta s nadezhdoi [From Tashkent with hope]" Neft' $i$ Kapital, March 
Neft' i Kapital (2013) 'Zhdem peremen [Waiting for changes]" Neft' $i$ Kapital, June

Neftegazovaya vertikal' (2005) "LUKOIL: po materialam godovogo otcheta [Lukoil: an analysis of the annual report]" Neftegazovaya vertikal', No. 11, 8 August

Neftegazovaya vertikal' (2006a) "Individual'nyi pocherk. Chast' 1 [Individual style. Part 1]" Neftegazovaya vertikal', No. 5, 10 April

Neftegazovaya vertikal' (2006b) "NK 'Lukoil': strategiya udvoeniya [Lukoil: a strategy for doubling]" Neftegazovaya vertikal', No. 16, 16 November

Neftegazovaya vertikal' (2007) "Lukoil v Uzbekistane: Igraet po-krupnomu [Lukoil plays a serious game in Uzbekistan]" Neftegazovaya vertikal', No. 1, 16 January

Neftegazovaya vertikal' (2010a) "Eksport nefti i nefteproduktov [Oil and oil products export]" Neftegazovaya vertikal', No. 5, pp.73-89

Neftegazovaya vertikal' (2010b) "Resursnaya baza: 'Slivki' konchilis' [The resource base: no cream left]" Neftegazovaya vertikal', No. 5, pp.40-53

Neftegazovaya vertikal' (2010c) "TNK-BP 2000-2010 v tsifrakh [TNK-BP 2000-2010 in numbers]" Neftegazovaya vertikal', No. 22, pp.22-27

Neftegazovaya vertikal' (2011a) "Rosneft': Osvoenie shel'fa [Rosneft: opening up the shelf]" Neftegazovaya vertikal', Nos 15-16, pp.28-30

Neftegazovaya vertikal' (2011b) "Podarok sud'by [A gift of fortune]" Neftegazovaya vertikal', Nos 15-16, pp.4-15

Neftegazovaya vertikal' (2011c) "Neftyanaya otrasl' Respubliki Kazakhstan [The oil industry in the Republic of Kazakhstan]" Neftegazovaya vertikal', No. 20, pp.28-33

Neftegazovaya vertikal' (2011d) "Spekulyanty ne veryat v neftyanku [The speculants do not believe in oil business]" Neftegazovaya vertikal', No. 3, pp.52-59

Neftegazovaya vertikal' (2012a) "Antisobytiya goda. Reitingovyi obzor 'Neftegazovoi vertikali' [The non-events of the year. Neftegazovaya vertikal's rating survey]" Neftegazovaya vertikal', No. 1, pp.17-21

Neftegazovaya vertikal' (2012b) “Tendentsii goda. Reitingovyi obzor 'Neftegazovoi vertikali' [The trends of the year. Neftegazovaya vertikal's rating survey]" Neftegazovaya vertikal', No. 1, pp.22-26

Neftegazovaya vertikal' (2016a) "Lukoil' ne vidit riskov dlya SP s 'Bashneftyu' posle privatizatsii etoi kompanii - Alekperov [Alekperov: Lukoil does not see any risks for the JV with Bashneft after the privatisation of the company]" [online]. 12 October. Moscow. Available from: http://www.ngv.ru/news/lukoyl_ne_vidit_riskov_dlya_sp_s_ bashneftyu_posle_privatizatsii_etoy_kompanii_alekperov_/ Accessed 22 March 2019]

Neftegazovaya vertikal' (2016b) "Pyat' pyatiletok Lukoila [Lukoil's five five-year plans]" Neftegazovaya vertikal', No. 22, pp.12-18

Neftegazovaya vertikal' (2016c) "Mirnaya ekspansiya [Peaceful expansion]" Neftegazovaya vertikal', No. 22, pp.32-39

Neftegazovaya vertikal' (2016d) "Valerii Graifer: Vertikal'naya integratsiya nachinalas' s Lukoila [Valerii Graifer: Vertical integration started with Lukoil]" Neftegazovaya vertikal', No. 22, pp.20-25

Neftegazovaya vertikal' (2017a) "Vyekhat' na gaze. V Srednei Azii problemy s dobychei nefti probuyut kompensirovat' pererabotkoi gaza [Going out on gas. Central Asia tries to compensate oil production problems with gas processing]" Neftegazovaya vertikal', No. 11, pp.58-62

Neftegazovaya vertikal' (2017b) "Mikhail Krutikhin: Sozdanie VINK - men'shee iz zol [Mikhail Krutikhin: The creation of the vertically integrated oil companies was the lesser evil]" Neftegazovaya vertikal', No. 21, pp.28-34 
Neftegazovaya vertikal' (2017c) "Ne tol'ko megaproekty [Not just mega-projects]" Neftegazovaya vertikal', No. 9, pp.52-56

Nekrasov, V.I. (2007) "Vystuplenie pervogo vitse-prezidenta OAO "Lukoil” V.I. Nekrasova na zasedanii "kruglogo stola" po neftepererabotke i neftekhimii v Sovete Federatsii RF [Testimony of Lukoil's first vice president V.I. Nekrasov at the meeting of the Roundtable on oil refining and the petrochemical industry in the Federation Council of the Russian Federation]" [online]. 4 July 2007 (Moscow: Lukoil). Available from: http://www.lukoil.ru/press.asp?div_id=2\&id=1123\&year=2007 [Accessed 23 January 2012]

Nikitin, N. (2010) "Benefitsiar neftyanoi perepisi [The beneficiary of the oil inventory]" Neftegazovaya vertikal', No. 21, p.56

Nikitin, N. (2011) "Ogosudarstvlenie v zakone [Transfer into state ownership by law]" Neftegazovaya vertikal', No. 8, p.4-12

Nikolaeva, A. and Bekker, A. (2006) "Pokhod na Kavkaz [Caucasian campaign]" Vedomosti, 2 October

Novolodskaya, S. (2001) “'LUKOIL' ob”edinyaetsya s 'Iteroi' [Lukoil unites with Itera]" Vedomosti, 24 July

O’Cinneide, E. (2011) "Lukoil plans \$48bn splurge" Upstream, 1 December

Oilcapital.ru (2010) "Lukoil prizyvaet Pravitel'stvo RF rasprostranit' nalogovye l'goty na novye neftyanye provintsii [Lukoil calls on the Russian government to extend tax breaks to new oil provinces]" 29 January

Oilcapital.ru (2012a) "LUKOIL budet transportirovat' dobytuyu na Kaspii neft' po sisteme KTK - Alekperov [Alekperov: Lukoil will transport its Caspian oil through the CPC system]" [online]. 16 May (Moscow: IG Industriya). Available from: https://oilcap ital.ru/news/companies/16-05-2012/lukoyl-budet-transportirovat-dobytuyu-na-kaspiineft-po-sisteme-ktk-alekperov [Accessed 20 February 2019]

Oilcapital.ru (2012b) "Reiting vliyaniya krupnykh predprinimatelei i top-menedzherov toplivno-energeticheskogo kompleksa $\mathrm{v}$ dekabre $2012 \mathrm{~g}$. [Rating of the influence of major businessmen and top managers in the fuel and energy complex, December 2012]" [online]. 6 December (Moscow: IG Industriya). Available from: https:/oilcapital.ru/ news/companies/06-12-2012/reyting-vliyaniya-krupnyh-predprinimateley-i-top-menedz herov-tek-v-dekabre-2012-g [Accessed 18 March 2019]

Oilcapital.ru (2014a) “Glava 'LUKOILa' Alekperov prosit pravitel'stvo zamorozit' tarify 'Transnefti', RZhD i portovye sbory v usloviyakh sanktsii [Lukoil head Alekperov asks government to freeze Transneft, RZhD tariffs and port rates due to sanctions]" [online]. 6 November 2014 (Moscow: IG Industriya). Available from: https:/oilcapital.ru/news/ transport/06-11-2014/glava-lukoyla-alekperov-prosit-pravitelstvo-zamorozit-tarify-tran snefti-rzhd-i-portovye-sbory-v-usloviyah-sanktsiy [Accessed 18 March 2019]

Oilcapital.ru (2014b) “'LUKOIL' poka ne vidit ostroi neobkhodimosti v privlechenii sredstv $\mathrm{s}$ vneshnikh rynkov [Lukoil does not yet see any urgency in attracting finance from external markets]" [online]. 5 June (Moscow: IG Industriya). Available from: https:// oilcapital.ru/news/companies/05-06-2014/lukoyl-poka-ne-vidit-ostroy-neobhodimosti-v-p rivlechenii-sredstv-s-vneshnih-rynkov [Accessed 20 March 2019]

Oilcapital.ru (2014c) “"Vnuchka' 'Gazproma' uidet iz Kryma iz-za ugrozy sanktsii [Gazprom's granddaughter leaves Crimea due to the threat of sanctions]" [online]. 25 August (Moscow: IG Industriya). Available from: https:/oilcapital.ru/news/companies/25-082014/vnuchka-gazproma-uydet-iz-kryma-iz-za-ugrozy-sanktsiy [Accessed 20 March 2019] 
Oilcapital.ru (2014d) 'Situatsiya na Ukraine nikak ne skazalas' na rabote predpriyatiy LUKOILa $\mathrm{v}$ strane [The situation in Ukraine has not affected Lukoil's business in the country in any way]" [online]. 17 April (Moscow: IG Industriya). Available from: https:// oilcapital.ru/news/companies/17-04-2014/situatsiya-na-ukraine-ne-skazalas-na-rabote-pr edpriyatiy-lukoyla-v-strane [Accessed 20 March 2019]

Oilcapital.ru (2014e) "Roznichnyi biznes 'LUKOILa' na Ukraine pokupaet avstriiskaya AMIC [Lukoil's retail business in Ukraine acquired by Austrian AMIC]" [online]. 31 July (Moscow: IG Industriya). Available from: https:/oilcapital.ru/news/companies/ 31-07-2014/roznichnyy-biznes-lukoyla-na-ukraine-pokupaet-avstriyskaya-amic [Accessed 20 March 2019]

Oilcapital.ru (2014f) 'Zapravki 'LUKOILa' na Ukraine blokiruyut - OBSE [OSCE: Lukoil's petrol stations in Ukraine are blockaded]" [online]. 29 July (Moscow: IG Industriya). Available from: https://oilcapital.ru/news/companies/29-07-2014/zapra vki-lukoyla-na-ukraine-blokiruyut-obse [Accessed 20 March 2019]

Oilcapital.ru (2015a) “'LUKOIL' predlagaet prodlit' l'goty po NDPI dlya mestorozhdeniya Kaspiya na 10 let. Ob etom zayavil v Gosdume glava NK 'LUKOIL' Vagit Alekperov [Lukoil proposes to extend mineral extraction tax reductions for Caspian deposits by 10 years, as declared by Lukoil head Vagit Alekperov in the State Duma]" [online]. 2 June (Moscow: IG Industriya). Available from: https://oilcapital.ru/news/companies/ 02-06-2015/lukoyl-predlagaet-prodlit-lgoty-po-ndpi-dlya-mestorozhdeniy-kaspiya-na10-let [Accessed 18 March 2019]

Oilcapital.ru (2015b) “Sektoral'nye sanktsii okazali neznachitel'noe vliyanie na deyatel'nost' LUKOILa - Alekperov [Alekperov: The sectoral sanctions have had little impact on Lukoil's business]" [online]. 25 June (Moscow: IG Industriya). Available from: https://oilcapital.ru/news/companies/25-06-2015/sektoralnye-sanktsii-okazali-ne znachitelnoe-vliyanie-na-deyatelnost-lukoyla-alekperov [Accessed 25 February 2019]

Oilcapital.ru (2015c) “'Lukoil' i 'Gazprom' otlozhili burenie na Tsentral'nom mestorozhdenii do snyatiya sanktsii [Lukoil and Gazprom delay drilling on the Tsentral'noe field until sanctions are lifted]" [online]. 24 December (Moscow: IG Industriya). Available from: https://oilcapital.ru/news/Upstream/24-12-2015/lukoyl-i-gazprom-otlozhiliburenie-na-tsentralnom-mestorozhdenii-do-snyatiya-sanktsiy [Accessed 20 February 2019]

Oilcapital.ru (2015d) "'Lukoil”" vygodno prodal aktiv v Kazakhstane kitaitsam [Lukoil sold its active in Kazakhstan to China, at a profit]" [online]. 21 August (Moscow: IG Industriya). Available from: https://oilcapital.ru/news/companies/21-08-2015/lukoyl-vy godno-prodal-aktiv-v-kazahstane-kitaytsam [Accessed 21 February 2019]

Oilcapital.ru (2016a) "Reiting vliyaniya krupnykh predprinimatelei i top-menedzherov toplivno-energeticheskogo kompleksa v marte $2016 \mathrm{~g}$. [Rating of the influence of major businessmen and top managers in the fuel and energy complex, March 2016]" [online]. 29 March (Moscow: IG Industriya). Available from: https:/oilcapital.ru/news/compa nies/29-03-2016/reyting-vliyaniya-krupnyh-predprinimateley-i-top-menedzherov-topliv no-energeticheskogo-kompleksa-v-marte-2016-g [Accessed 20 February 2019]

Oilcapital.ru (2016b) “Alekperov nadeetsya na OPEK, no ne verit v realistichnost' 'Soglasiya' [Alekperov places hopes on OPEC, but does not believe in the realism of a 'deal']" [online]. 16 November (Moscow: IG Industriya). Available from: https:// oilcapital.ru/news/companies/16-11-2016/alekperov-nadeetsya-na-opek-no-ne-ver it-v-realistichnost-soglasiya [Accessed 21 March 2019]

Oilcapital.ru (2016c) "'Bashneft": Prodano! 'Rosneft” kupila kompaniyu s premiei k rynku [Bashneft: Sold! Rosneft buys the company above the market price]" [online]. 2 
December (Moscow: IG Industriya). Available from: https://oilcapital.ru/news/compa nies/02-12-2016/bashneft-prodano-rosneft-kupila-kompaniyu-s-premiey-k-rynku [Acce ssed 21 March 2019]

Oilcapital.ru (2016d) “'Lukoil' poluchil razreshenie na postavki diztopliva grazhdanskim potrebitelyam Ukrainy [LUkoil allowed to supply diesel to civilian customers in Ukraine]" [online]. 30 March (Moscow: IG Industriya). Available from: https:// oilcapital.ru/news/export/30-03-2016/lukoyl-poluchil-razreshenie-na-postavki-diztop liva-grazhdanskim-potrebitelyam-ukrainy [Accessed 18 February 2019]

Oilcapital.ru (2017a) “Azerbaidzhan predlagaet 'LUKOILu' ispol'zovat' nefteprovod BTD dlya nefti s mestorozhdeniya Filanovskogo [Azerbaijan offers use of BTC pipeline to Lukoil to use for oil from the Filanovsky field]" [online]. 13 October (Moscow: IG Industriya). Available from: https://oilcapital.ru/news/transport/13-10-2017/azerba ydzhan-predlagaet-lukoylu-ispolzovat-nefteprovod-btd-dlya-nefti-s-mestorozhdeniyafilanovskogo [Accessed 20 February 2019]

Oilcapital.ru (2017b) “'LUKOIL' ne planiruyet prodavat' dolyu v SP po razrabotke mestorozhdenii Trebsa i Titova [Lukoil does not plan to sell its share of the JV for development of the Trebs and Titov fields]" [online]. 19 January (Moscow: IG Industriya). Available from: https://oilcapital.ru/news/companies/19-01-2017/lukoyl-ne-planiruetprodavat-dolyu-v-sp-po-razrabotke-mestorozhdeniy-trebsa-i-titova [Accessed 22 March 2019]

Oilcapital.ru (2018) "Kaspiiskaya konventsiya: uzh luchshe takaya, chem nikakaya [The Caspian Convention: better still this one than none]" [online]. 1 August (Moscow: IG Industriya). Available from: https://oilcapital.ru/article/general/01-08-2018/kaspiyskaya -konventsiya-uzh-luchshe-takaya-chem-nikakaya [Accessed 18 February 2019]

Oilcapital.ru (2019a) "Negativno vliyayut sanktsii na 'Lukoil', odnako adaptatsiya vozmozhna [The sanctions impact Lukoil negatively, but adaptation is possible]" [online]. 12 March (Moscow: IG Industriya). Available from: https://oilcapital.ru/ news/companies/12-03-2019/negativno-vliyayut-sanktsii-na-lukoyl-odnako-adaptatsi ya-vozmozhna [Accessed 13 March 2019]

Oilcapital.ru (2019b) "6 trln rublei zarabotala Rossiya za vremya sdelki OPEK+ [Russia earned 6 trillion rubles for the duration of OPEC+]" [online]. 13 February (Moscow: IG Industriya). Available from: https://oilcapital.ru/news/markets/14-02-2019/6-trln-ru bley-zarabotala-rossiya-za-vremya-sdelki-opek [Accessed 21 March 2019]

Orekhin, P. (2010) "Bol'shoi priz [The big prize]" Profil', 27 September 2010, pp.6-11

Orekhin, P., Naumov, I. and Ivzhenko, T. (2005) "Fradkov otkazalsya zashchishchat' neftyanikov. Rost tsen na benzin prodolzhaetsya [Fradkov declined to defend the oilmen. The petrol price rise continues]" Nezavisimaya gazeta, 21 April 2005, p.1

Petrachkova, A. (2006) "Interes k Tadzhikistanu [An interest in Tajikistan]" Vedomosti, 18 September

Pravosudov, S. (2000) "Interv'yu L.A. Feduna zhurnalu Russkii Fokus [Interview with L. A. Fedun with the magazine Russkii Fokus]" Russkii Fokus, 5 December

Pravosudov, S. (2003) "Vagit Alekperov: 'Otkuda vy znaete, chto Kukuru ukrali beznakazanno?' [Vagit Alekperov: 'How do you know that Kukura was kidnapped with impunity?" Russkii Fokus, 14 April

Rachkov, B. (2001) "U biznesa i vlasti zaboty obshchie [The business sector and the authorities have common worries]" Ekonomika i zhizn', 23 June

Razumovskii, K. (1998) "Privatizatsiya 'Linosa': Vtoraya popytka [The privatisation of Linos: a second attempt]" Kommersant, 16 January 1998, p.11 
Razumovskii, K. (2001) "Novaya strategiya LUKOILa na Ukraine [Lukoil's new strategy in Ukraine]" Kommersant, 27 September 2001, p.4

RBK (2018) "RBK 500: Reiting rossiiskogo biznesa [RBK 500: The Russian Business Rating]" [online]. Moscow: Available from: https://www.rbc.ru/rbc500/ [Accessed 23 November 2018]

Rebrov, D. (2010a) "Nashi aktsionery riskuyut [Our shareholders take a risk]" Kommersant, 24 June 2010, p.10

Rebrov, D. (2010b) "LUKOILu ne khvataet gaza na polipropilenovyi zavod v Budennovske [Lukoil does not have enough gas for a polypropylene factory in Budennovsk]" Kommersant, 24 June 2010, p.9

Rebrov, D. and Skorlygina, N. (2006) "LUKOIL vyrastet na gaze [Lukoil will grow on gas]" Kommersant, 19 October 2006, p.13

Rebrov, D. and Konstantinov, A. (2008) "LUKOIL ne srabotalsya s CNPC [Lukoil and CNPC did not work well together]" Kommersant, 23 June 2008, p.9

Rebrov, D., Naumova, A. and Tomashevskaya, O. (2006) "Bez nefti vinovatyi [Guilty of no oil]" Vremya novostei, 19 January, p.7

Reuters (2018) "Russia's Lukoil says banks stricter with it after US 'oligarch list"” [online]. 15 February (London: Reuters). Available from: https://www.reuters.com/a rticle/us-russia-lukoil-banks-sanctions/russias-lukoil-says-banks-stricter-with-it-afteru-s-oligarch-list-idUSKCN1FZ19A [Accessed 14 March 2019]

RFE/RL (1996) "RFE/RL Newsline" Radio Free Europe/Radio Liberty, 17 April

RIA Novosti (2009) "Russia, Venezuela sign raft of energy, military deals" [online]. (Moscow: RIA Novosti). Available from: http://en.rian.ru/russia/20090910/ 156088746.html [Accessed 16 February 2019]

Rogers, D. (2015) The depths of Russia. Oil, power, and culture after socialism (Ithaca/ London: Cornell University Press)

Romanova, L. (1999) "Interesy 'neftyanoi diplomatii' [The interests of 'oil diplomacy']" Nezavisimaya gazeta - Sodruzhestvo, 24 February

Romanova, L. and San'ko, V. (1999) "Vagit Alekperov: 'Vse nado schitat" [Vagit Alekperov: 'Everything must be taken into account']" Nezavisimaya gazeta, 27 August, p.4

Rybal'chenko, I. (2000) "Mazeikiu Nafta rasschitivaet na rossiiskuyu neft' [Mazeikiu Nafta counts on Russian oil]" Kommersant, 9 December 2000, p.5

Rybal'chenko, I. (2001) "LUKoil' menyaet investitsii na tarify [Lukoil exchanges investments for tariffs]" Kommersant, 10 February 2001, p.3

Sapozhnikov, P. (2002) "LUKOIL vygodno prodal nedra Azerbaidzhana [Lukoil sold Azerbaijan's mineral wealth profitably]" Kommersant, 21 December 2002, p.4

Sapozhnikov, P. and Khvostik, E. (2004) "LUKOIL kupil ital'yanskuyu polovinu [Lukol buys the Italian half]" Kommersant, 1 July 2004, p.1

Sapozhnikov, P., Sborov, A. and Mamaev, S. (2002) "LUKOIL rasprodaet nedra Azerbaidzhana [Lukoil sells out Azerbaijan's mineral wealth]" Kommersant, 18 November 2002, p. 1

Savushkin, S. (2005) "Kremlevskii kapitalizm na marshe [Kremlin capitalism marches ahead]" Neft' $i$ Kapital, October

Sborov, A. (2000) "Kalyuzhnyi poshel po delu 'LUKoila' v Baku [Kalyuzhnyi goes to Baku on the Lukoil case]" Kommersant, 14 July, p.3

Sharip, F. (2012) "Uzbekistan's quest for Aral Sea oil may weaken Kazakhstan's position in the Caspian" Eurasia Daily Monitor, 2 February

Shevel'kova, O. (2008) "'Padenie dobychi - eto uzhe tendentsiya' [Falling production is already a tendency]" SmartMoney, 12 May 2008, p.24 
Shiryaev, V. (1999) “'LUKoil' mogut poprosit' s Odesskogo NPZ, esli on ne budet vypolnyat' svoikh obyazatel'stv [Lukoil may be asked to leave the Odesa oil refinery if it does not fulfil its obligations]" Novye izvestiya, 23 December

Shumilin, A. (1997) "Sergei Markov: LUKOIL sil'nee MIDa [Sergei Markov: Lukoil is stronger than the MFA]" Kommersant, 23 July 1997, p.4

Sidorov, E. (2001) “'Takoi nalog nam ne nuzhen...' 'Starye' neftyanye kompanii nadeyutsya na ponimanie deputatskogo korpusa ['We don't want this tax...' The 'old' oil companies hope for understanding from deputies]" Nezavisimaya gazeta, 3 July 2001, p.4

Sivakov, D. and Vin'kov, A. (2007) "Prosto ne nado zhadnichat' [Just don’t be greedy]" Ekspert, 12 November 2007, pp.32-39

Skorlygina, N. (2006) "LUKOIL stolknulsya s kitaiskoi ugrozoi [Lukoil clashes with the Chinese threat]" Kommersant, 27 October 2006, p.17

Skorlygina, N. and Rebrov, D. (2007) "LUKOIL obmenyaetsya aktivami s CNPC [Lukoil will exchange equity with CNPC]" Kommersant, 13 September 2007, p.13

Skorobogat'ko, D. (2004) "LUKOIL zarabotal na nalogi [Lukoil has worked on taxes]" Kommersant, 14 January 2004, p.16

Skorobogat'ko, D. (2005) “Minoritarii Nelson soglasilis' na tsenu LUKOILa [Nelson's minority shareholders agree to Lukoil's price]" Kommersant, 21 October 2005, p.15

Slavinskaya, L. (2011) "Geopoliticheskii afront: Rossiya protiv vsekh? [Geopolitical affront: Russia against all?]" Neftegazovaya vertikal', No. 20, pp.44 47

Smirnov, A. (1995) "Neftyanye kompanii delyat resursy nepodelennogo Kaspiya [The oil companies divide the resources of the undivided Caspian]" Kommersant, 10 November 1995, p.1

Smirnov, K. (2002) "Zachem oni tuda khodyat [Why they go there]" KommersantVlast', 21 May

Socor, V. (2009) "Lukoil acquires major stake in Netherlands refinery and marketing" Eurasia Daily Monitor, 26 June

Socor, V. (2013) "Ukraine launches major gas extraction projects with Western companies" Eurasia Daily Monitor, 8 November

Socor, V. (2014) "Beyond Shah Deniz: Azerbaijan's next-generation gas" Eurasia Daily Monitor, 29 January

Stalker, A. (1995) "Rossiiskie neftyaniki zakreplyayutsya v Srednei Azii [Russian oilmen consolidate their hold in Central Asia]" Kommersant, 14 April

Starinskaya, G. and Serov, M. (2015a) "'U nas ni razu ne bylo udachi v peregovorakh s kitaiskimi bankami" ['We never had any luck in negotiations with Chinese banks']" Vedomosti, 7 September. Available from: https://www.vedomosti.ru/busi ness/video/2015/09/07/607775-u-nas-ne-bilo-udachi-s-kitaiskimi-bankami [Accessed 31 March 2020]

Starinskaya, G. and Serov, M. (2015b) “'Kitaiskie kredity - samye dorogie v mire' ['Chinese credits are the most expensive in the world']" Vedomosti, 6 September

Starinskaya, G., Kashevarova, A. and Korytina, E. (2010) "Glava 'Rosnefti' mozhet stat' ministrom energetiki [The head of Rosneft may become energy minister]" $R B C$ Daily, 26 August 2010

Stolyarov, B. (1999) "Professiya: oligarkh. A za chto, skazhite, nas ne lyubit'?! Prezident LUKOILa o svoikh vzaimootnosheniyakh s gosudarstvom [Profession: oligarch. And why, please, should we not be loved? Lukoil's president on his mutual relations with the state]" Novaya gazeta, 29 November

Suleimenov, M. (2005) “Kazakhstanskaya dolya [Kazakhstan's share]” Neft' i Kapital, December 
The New Times (2019) "Vitse-prem'er Yurii Trutnev: investoram v Arktike nuzhny nalogovye kanikuly i l'goty [Vice-premier Yurii Trutnev: Investors in the Arctic need tax breaks and deductions]" The New Times/Novoe Vremya, 4 March

Timoshchenko, V. (2001) "Do Novogo goda eshche daleko, a god Ukrainy uzhe nachinaetsya. Protsessom sblizheniya dvukh bratskikh gosudarstv budut upravlyat' 'kapitany' rossiiskoi ekonomiki [New Year is still far off, but the Year of Ukraine is already starting. The 'captains' of the Russian economy are in charge of the rapprochement process between the two brotherly states]" Nezavisimaya gazeta, 29 November 2001, p.5

Today.kz (2010) “'PetroKazakhstan' i LUKOIL uregulirovali spor po 'Turgai Petroleum' [PetroKazakhstan and Lukoil have regulated their dispute over Turgai Petroleum]" Today.kz, 24 August

Tovkailo, M. (2012) "Propusk na shel'f [Admission to the shelf]" Vedomosti, 3 August

Tret'yakov, P. (2015) “Kitaiskie investory ne speshat vkhodit' v rossiiskie aktivy [Chinese investors are in no haste to acquire Russian equity]" Vedomosti, 5 May

Tutushkin, A. (1995) “'LUKoil' stal liderom mezhdunarodnogo proekta v Azerbaidzhane [Lukoil becomes the leader of an international project in Azerbaijan]" Kommersant, 14 November 1995, p.9

Tutushkin, A. (1996a) "LUKOIL metit territorii benzokolonkami [Lukoil marks territories with petrol pumps]" Kommersant, 11 July 1996, p.9

Tutushkin, A. (1996b) "Vagit Alekperov: My ne khotim teryat' svyaz' s gosudarstvom [Vagit Alekperov: We do not want to lose our ties to the government]" Kommersant, 6 February 1996, p.10

Tutushkin, A. (1999) “Vagit Alekperov: 'Esli by ne Lukoil...' [Vagit Alekperov: 'If not for Lukoil...']" Vremya MN, 5 November

Tutushkin, A. (2000) “Zashchita Alekperova [Alekperov's defence]" Vedomosti, 9 June

Tutushkin, A. (2003) 'Interv'yu: Vagit Alekperov, prezident neftyanoi kompanii 'Lukoil' [Interview: Vagit Alekperov, president of the oil company Lukoil]" Vedomosti, 20 June

Tutushkin, A. (2004) "Interv'yu: Vagit Alekperov, prezident NK 'Lukoil' [Interview. Vagit Alekperov, president the oil company Lukoil]" Vedomosti, 23 June

Tutushkin, A. (2008) "'U menya prochnoe sovetskoe vospitanie', - Vagit Alekperov, prezident 'Lukoila' ['I have a solid Soviet upbringing', says Vagit Alekperov, Lukoil's president]" Vedomosti, 1 September

Tutushkin, A., Ivanitskaya, N. and Kramnets, G. (2007) "'Lyudi ne dolzhny boyat'sya' ['People should not be scared']" Vedomosti, 10 October

Tutushkin, A. et al. (2004) "Putin dal dobro. Na investitsii ConocoPhillips v aktsii 'LUKOILa' [Putin approved. Of ConocoPhillips's investments in Lukoil shares]" Vedomosti, 23 July

US Congress (02/08/2017) Countering America's adversaries through Sanctions Act (Washington, DC: Congress of the United States.)

US Department of the Treasury (2018) Report to Congress Pursuant to Section 241 of the Countering America's Adversaries Through Sanctions Act of 2017 Regarding Senior Foreign Political Figures and Oligarchs in the Russian Federation and Russian Parastatal Entities (Washington, DC: US Dept of the Treasury)

Upstream (1997) "Russians shift on Caspian carve-up" Upstream, 25 October

Upstream (1998a) "Lukoil's boss bows to the Kazakhs" Upstream, 24 January

Upstream (1998b) "Caspian Sea thaw" Upstream, 31 January

Upstream (2001) "Lukoil eyes Baku-Ceyhan stake" Upstream, 26 December

Upstream (2010) "Lukoil, CNPC talk team up" Upstream, 28 September 
Useinov, A. (2001) "Diskussiya o truboprovodakh [A discussion on pipelines]" Vremya novostei, 16 November, p.2

Useinov, A. (2002) “'Bol'she blagozhelatel'nosti, bol'she dobrososedstva'. Geidar Aliev opyat' stal drugom Rossii ['More goodwill, more good-neighbourliness'. Heydar Aliev is again friends with Russia]" Vremya novostei, 24 January, p.2

Vahtra, P. and Liuhto, K. (2004) Expansion or exodus? - Foreign operations of Russia's largest corporations. Electronic Publications of Pan-European Institute. 8/2004. (Turku, Finland: Turku School of Economics and Business Administration)

Vandenko, A. (1999) "Prezident Ukrainy Leonid KUCHMA: Ya 38 let zhenat na russkoi, o chem nikogda ne zhalel [Ukraine's president Leonid Kuchma: I've been married to a Russian woman for 38 years, and never regretted]" Komsomol'skaya Pravda, 29 September

Vardul', N. (1995) “Azartna lyubaya igra v karty. Osobenno v geograficheskie [Any card game is a game of chance. Especially a geography game]" Kommersant-Vlast', 29 August 1995, p.12

Vedomosti (1999) "Zolotaya reviziya [Golden revision]" Vedomosti, 15 November

Vedomosti (2002a) "Baku-Dzheikhan postroyat bez Rossii [Baku-Ceyhan will be built without Russia]" Vedomosti, 17 April

Vedomosti (2002b) "Pogovorili [Someone had a chat]" Vedomosti, 12 April

Vedomosti (2005) "Interv'yu: Vagit Alekperov, prezident NK 'LUKOIL' [Interview: Vagit Alekperov, president of the oil company Lukoil]" Vedomosti, 11 July

Vedomosti (2012) "Vkrattse [In brief]" Vedomosti, 4 June

Victor, D.G., Hults, D.R. and Thurber, M.C. (ed.) (2012) Oil and Governance. Stateowned Enterprises and the World Energy Supply (Cambridge: Cambridge University Press)

Vin'kov, A., Rubanov, I. and Sivakov, D. (2011) "Zametit' korovu v korovnike [To notice the cow in the cowshed]" Ekspert, 28 March 2011, pp.36-44

Vin'kov, A. et al. (2004) "Tsena bezdeistviya [The cost of doing nothing]" Ekspert, 11 October, pp.38-43

Vinogradova, O. (2003) "Kozyrnaya karta uzbekskogo gaza [The trump card of Uzbek gas]" Neftegazovaya vertikal', 6 December 2003

Vinogradova, O. (2010) “Total'nyi kontrol' pridet vmeste s zakonom o nefti [Total control will come with the Law on oil]" Neftegazovaya vertikal', pp.52-57

Vinogradova, O. (2011) "Nastuplenie na Chernoe more [An offensive on the Black Sea]" Neftegazovaya vertikal', pp.70-74

Weaver, C., Hille, K. and Seddon, M. (2018) "US imposes toughest Russian sanctions to date" The Financial Times, 6 April

Yakovleva-Ustinova, T. (2004) "Interv'yu. Andrei Gaidamaka, nachal'nik upravleniya investitsionnogo analiza i otnoshenii s investorami LUKOILa: 'My vynuzhdeny izobretat' novye transportnye skhemy' [Interview. Andrei Gaidamaka, head of the Department for investment analysis and investor relations in Lukoil: "We have to devise new transport plans']" Kommersant, 26 October 2004, p.20

Yergin, D. (2012 (1993)) The Prize. The epic quest for oil, money and power (London/ New York: Simon \& Schuster)

Yermakov, V. (2001) New Russian oil taxes: A World of the Second Best? Cambridge Energy Research Associates Decision Brief. (Cambridge, MA: Cambridge Energy Research Associates) 
Zagorodnaya, E. (2003) "Vagit Alekperov: 'My gotovy k tomu, chtoby dinamichno razvivat'sya' [Vagit Alekperov: 'We are ready for dynamic development']" Izvestiya, 26 June 2003, p.7

Zotova, E. (2008) "Zapasnoi platsdarm Lukoila. Ekspansiya za rubezh - edinstvennaya vozmozhnost' razvitiya dlya negosudarstvennykh neftegazovykh kompanii [Lukoil's reserve base. Expanding abroad is the only possibility to develop for nonstate oil and gas companies]" Business \& FM, 25 January 2008

Zudin, A.Yu. (2013) "Biznes i gosudarstvo v Rossii: opyt primeneniya podkhoda Norta-Uollisa-Vaingasta. Stat'ya 1. Etapy razvitiya rossiiskikh biznes-assotsiatsii [Business and the state in Russia: an attempt at applying the approach of NorthWallis-Weingast. Article 1. Stages in the development of Russian business associations", Obshchestvennye nauki i sovremennost', 2013 (2): 15-31

Aleksandrov, Yu. and Orlov, D. (2001) "Truboprovodnaya ekspansiya Rossii. Radikal'noe usilenie roli nashei strany na prostranstve SNG nachinaetsya so stroitel'stva magistral'nykh nefteprovodov [Russia's pipeline expansion. The radical strengthening of our country's role in the CIS begins with the construction of trunk oil pipelines]" NG Politekonomiya, 17 April, p.6

Aleksandrovich, S. (2001) "Moskva-Baku: soobshchenie vozobnovlyaetsya [MoscowBaku: contact is renewed]" Neft' i Kapital, January

Analiticheskii Tsentr (2014a) Stimulirovanie razvitiya vozobnovlyaemoi energetiki [Stimulating the development of renewable energy]. Energeticheskii byulleten' 17, September. (Moscow: Analiticheskii Tsentr pri Pravitel'stve Rossiiskoi Federatsii/ Analytical Center for the Government of the Russian Federation)

Analiticheskii Tsentr (2014b) Energeticheskaya bednost' $i$ energeticheskaya obespechennost' [Energy poverty and energy prosperity]. Energeticheskii byulleten' 10, February. (Moscow: Analiticheskii Tsentr pri Pravitel'stve Rossiiskoi Federatsii/ Analytical Center for the Government of the Russian Federation)

Analiticheskii Tsentr (2015) Potentsial energeticheskogo sotrudnichestva stran BRIKS [The potential of energy cooperation among BRICS countries]. Energeticheskii byulleten' 26, July. (Moscow: Analiticheskii Tsentr pri Pravitel'stve Rossiiskoi Federatsii/ Analytical Center for the Government of the Russian Federation)

Analiticheskii Tsentr (2017a) V fokuse: Pribaltika-ozhivlenie posle Velikoi retsessii [In focus: The Baltic states - revival after the Great Recession]. Byulleten' o tekushchikh tendentsiyakh mirovoi ekonomiki 20, May. (Moscow: Analiticheskii Tsentr pri Pravitel'stve Rossiiskoi Federatsii/Analytical Center for the Government of the Russian Federation)

Analiticheskii Tsentr (2017b) Tekhnologicheskie prioritety v energetike [Technological priorities in electricity]. Energeticheskii byulleten' 47, April. (Moscow: Analiticheskii Tsentr pri Pravitel'stve Rossiiskoi Federatsii/Analytical Center for the Government of the Russian Federation)

Analiticheskii Tsentr (2017c) Novye prognozy mirovoi energetiki i mesto Rossii v nei [New prognoses for global energy and Russia's place in it]. Energeticheskii byulleten' 54, November. (Moscow: Analiticheskii Tsentr pri Pravitel'stve Rossiiskoi Federatsii/Analytical Center for the Government of the Russian Federation)

Anishyuk, A. (2010) "Talks frozen in Belarus oil dispute" Moscow Times, 11 January, p.1

APEK (2017) "Reiting vliyaniya krupnykh predprinimatelei i top-menedzherov toplivnoenergeticheskogo kompleksa v iyune $2017 \mathrm{~g}$. [Rating of the influence of major businessmen and top managers in the fuel and energy complex, June 2017]" [online]. 29 June (Moscow: Agentstvo politicheskikh i ekonomicheskikh kommunikatsii). 
Available from: http://apecom.ru/projects/item.php?SECTION_ID=102\&ELE MENT_ID=3803 [Accessed 18 March 2019]

Archi.ru (2019) “Nauchno-issledovatel'skii kompleks 'Primorskii okeanarium' (g.Vladivostok, ostrov Russkii) [The science research complex 'Primore ocean centre' (Vladivostok, Russkii Island)]” [online]. (Russia: Archi.ru). Available from: https://a rchi.ru/projects/russia/7750/nauchno-issledovatelskii-kompleks-primorskii-okeana rium-g-vladivostok-ostrov-russkii [Accessed 10 May 2019]

Audit Chamber (2009) "Schetnaya palata proverila raskhodovanie sredstv na stroitel'stvo TS "VSTO" [The Audit Chamber has audited the expenditure of funds in the construction of the transport system ESPO]" [online]. 2 February (Moscow: Schetnaya palata [Audit Chamber]). Available from: http://www.ach.gov.ru/press_center/ news/318 [Accessed 1 April 2019]

Audit Chamber (2015) "Investitsionnye programmy 'Transnefti' ne v polnoi mere sootvetstvuyut pokazatelyam strategicheskogo planirovaniya RF [Transneft's investment programmes do not completely comply with the Russian Federation's strategic planning indicators]" [online]. 18 March (Moscow: Schetnaya palata [Audit Chamber]). Available from: http://www.ach.gov.ru/activities/control/21054/ [Accessed 1 May 2019]

Audit Chamber (2017) Zaklyuchenie Schetnoi palaty Rossiiskoi Federatsii na proekt federal'nogo zakona "O federal'nom byudzhete na 2018 god i na planovyi period 2019 $i 2020$ godov" [The Audit Chamber's Conclusion on the federal law draft 'On the federal budget for 2018 and the planning period 2019 and 2020"'], (Moscow: Schetnaya Palata Rossiiskoi Federatsii)

Azarova, S. (1997) “'Baltiiskuyu truboprovodnuyu sistemu' reshili postroit' [Baltic Pipeline System decision made]" Neft' i Kapital, March

Babali, T. (2009) "Prospects of export routes for Kashagan oil", Energy Policy, 37: $1298-1308$

Balmaceda, M.M. (2008) Energy dependency, politics, and corruption in the Former Soviet Union. Russia's power, oligarchs' profits and Ukraine's missing energy policy, 1995-2006 (London/New York: Routledge)

Balmaceda, M.M. (2012) "Russia's central and eastern European energy transit corridor: Ukraine and Belarus" in Aalto, P. ed., Russia's energy policies. National, interregional and global levels (Cheltenham, UK/Northampton, USA: Edward Elgar), pp.136-155

Bazanova, E. and Petlevoi, V. (2019) "Dividendy ot sanktsii [Dividends from the sanctions]" Vedomosti, 18 April, p.10

Bekker, A. (1999a) "Sila i bessilie Putina [Putin's strength and impotence]" Vedomosti, 4 October

Bekker, A. (1999b) "Vainshtok stal tsarem truby [Vainshtok becomes tsar of the pipe]" Vedomosti, 17 September

Bekker, A. (2002) “Interv'yu: Viktor Khristenko, vitse-prem'er [Interview: Viktor Khristenko, vice premier]" Vedomosti, 25 March, p.A2

Bernstein, J. (2007) "Stanislav Belkovsky: Putin will leave power completely" Eurasia Daily Monitor, 19 November

Bernstein, J. (2008) "Belkovsky predicts Medvedev will tighten the screws" Eurasia Daily Monitor, 7 January

Bloomberg/The Moscow Times (2009) "Transneft in biggest bond issue" Moscow Times, 20 May

Bolukbasi, S. (1998) "The controversy over the Caspian Sea mineral resources: Conflicting perception, clashing interests”, Europe-Asia Studies, 50 (3): 397-414 
BP (2019) "Baku-Tbilisi-Ceyhan pipeline" [online]. (London: BP). Available from: https://www.bp.com/en_az/caspian/operationsprojects/pipelines/BTC.html[Accessed 2 May 2019]

Bradshaw, M. (2014) "The progress and potential of oil and gas exports from Pacific Russia" in Oxenstierna, S. and Tynkkynen, V.-P. eds, Russian energy and security up to 2030 (London/New York: Routledge), pp.192-212

Bratersky, A. (2010) "Transneft accused of \$4bln theft" The Moscow Times, 18 November, p. 1

Butrin, D. (2008) "Pravila igry [The rules of the game]" Kommersant, 1 February, p.13

Butrin, D. (2010) "Goskompanii vnosyat v dokhodnuyu chast' byudzheta [The state companies will be transferred to the profitable part of the budget]" Kommersant, 26 July, p. 2

Butrin, D. and Sapozhnikov, P. (2004) "Ukraine otkazali v legkoi nefti [Ukraine denied light oil]" Kommersant, 23 June, p.7

Butrin, D. and Rebrov, D. (2007) "Chevron vernula Rossii tarify KTK [Chevron returns CPC tariffs to Russia]" Kommersant, 20 September, p.14

Butyrina, E. (2007) “Berik Tolumbaev, AO 'KazTransOil': 'Glavnyi printsip nashei raboty sozdanie sovremennoi integrirovannoi nefteprovodnoi sistemy Kazakhstana' [Berik Tolumbaev, KazTransOil: 'The main principle of our work is to create a modern and integrated oil pipeline network in Kazakhstan']" Panorama, 16 February

Buyantseva, L. (2000) "Baku zagruzit 'Transneft" [Baku loads Transneft]" Vedomosti, 19 September

Buyantseva, L. and Osetinskaya, E. (2000) "Transneft" predlagaet skidku [Transneft offers a discount]" Vedomosti, 7 July

Chernitskii, O. (1999) "Mintop obvinyaet Dmitriya Savel'eva v rastrate [The Fuel Ministry is accusing Dmitrii Savelev of embezzlement]" Vedomosti, 12 November

Chernitskii, O. (2001a) "Vainshtok pozhalovalsya. V bor'be s KTK 'Transneft" rasschitivaet na pravitel'stvo [Vainshtok complains. In the campaign against CPC, Transneft counts on the government]" Vremya novostei, 6 June, p.4

Chernitskii, O. (2001b) "Igor' Yusufov: 'Sistema eksporta nefti budet spravedlivoi' [Igor Yusufov: 'The oil export system will be fair']" Vremya novostei, 14 September, p.1

CPC (2019) "Project chronology" [online]. n.d. (Moscow/Novorossiisk/Astana: Caspian Pipeline Consortium). Available from: http://www.cpc.ru/EN/about/Pages/ chronology.aspx [Accessed 23 April 2019]

Cutler, R.M. (2014) “Chinese energy companies' relations with Russia and Kazakhstan”, Perspectives on Global Development and Technology, 13 (5-6):673-698

Daborowski, T. (2011) "Bulgaria withdraws from the Trans-Balkan oil pipeline construction project" CeWeekly, 14 December

Davydova, M. (2000) “'Auktsionirovanie' neftyanogo eksporta. Pravitel'stvo izmenyaet poryadok vydachi kvot na vyvoz nefti [The auctioning of oil export. The government changes the order of oil export quota allocation]" Segodnya, 11 November, p.3

Davydova, M. (2001) "Neft' poidet s molotka [Oil will go under the hammer]" Kommersant, 29 May, p.8

Decree No. 327 (01/04/1995) O pervoocherednykh merakh po sovershenstvovaniyu deyatel'nosti neftyanykh kompanii [On first measures to perfect the operations of oil companies] (Moscow: President of the Russian Federation)

Decree No. 1285 (11/09/2012) O merakh po zashchite interesov Rossiiskoi Federatsii pri osushchestvlenii rossiiskimi yuridicheskimi litsami vneshneekonomicheskoi deyatel'nosti [On measures to protect the interests of the Russian Federation when foreign 
economic activity is carried out by a Russian juridical person] (Moscow: President of the Russian Federation)

Decree No. 1403 (17/11/1992) Ob osobennostyakh privatizatsii i preobrazovaniya v aktsionernye obshchestva gosudarstvennykh predpriyatii, proizvodstvennykh i nauchno-proizvodstvennykh ob"edinenii neftyanoi, neftepererabatyvayushchei promyshlennosti $i$ nefteproduktoobespecheniya [On the specificities of privatisation and conversion into shareholding companies of enterprises, production and scientific production associations in the oil and oil refinery industries and oil product distribution] (Moscow: President of the Russian Federation)

Delovoi Peterburg (1999a) "Primorsk poluchil dostup k nefti [Primorsk receives access to oil]" Delovoi Peterburg, 24 March

Delovoi Peterburg (1999b) "Primakov b'et po interesam finnov [Primakov combats Finnish interest]" Delovoi Peterburg, 24 February

Derbilova, E. (2006) “Interv'yu: Semen Vainshtok, prezident 'Transnefti' [Interview: Semen Vainshtok, president of Transneft]" Vedomosti, 6 June

Derbilova, E. (2007) "Rosneft" ne puskayut v Kitai [Rosneft is not let into China]" Vedomosti, 15 January

Derbilova, E. and Borisov, N. (2006) "Rossiya menyaet taktiku [Russia changes tactics]" Vedomosti, 13 January

Derbilova, E. and Bekker, A. (2006) "Vse sol'yut v trubu [Everyone will pour into the pipe]" Vedomosti, 4 May

Dmitriev, A. (2000) "Semen Vainshtok: Gosudarstvo dolzhno sebya zashchishchat' [Semyon Vainshtok: The state should defend itself]" Komsomol'skaya Pravda, 14 November, p.20

Dmitriev, A. (2002a) "Peremychka kak simvol kompromissa. Nefteprovod Baku-Novorossiisk i KTK budut soedineny blagodarya Vainshtoku i Alekperovu [A connection as a symbol of compromise. The Baku-Novorossiisk and CPC pipelines will be united thanks to Vainshtok and Alekperov]" Nezavisimaya gazeta, 29 January, p.11

Dmitriev, A. (2002b) "Snova Vainshtok. Godovoe sobranie aktsionerov 'Transnefti': s dividendami, no bez sensatsii [Vainshtok again. The annual shareholder meeting in Transneft: with dividends, but without sensations]" Nezavisimaya gazeta, 2 July, p.11

Dmitriev, A. (2003) "Sergei Grigor'ev: 'Vybor zavisit ot pravitel'stva, i tol'ko ot pravitel'stva'. Vitse-prezident kompanii 'Transneft" ubezhden o tom, chto chastnye nefteprovodnye proekty v Rossii ne slishkom perspektivny [Sergei Grigor'ev: 'The decision depends on the government, and only on the government'. Transneft's vicepresident is convinced that there is little promise in private oil pipeline projects in Russia]" Nezavisimaya gazeta, 28 March, p.10

Dodsworth, J.R., Mathieu, P.H. and Shiells, C.H. (2002) Cross-border issues in energy trade in the CIS countries. IMF Policy Discussion Paper (Washington, DC: International Monetary Fund)

Dospekhov, A. (2008) "Rossiiskomu khokkeyu pokazali amerikanskie printsipy [American principles are held up to Russian hockey]" Kommersant, 12 March, p.24

Drankina, E. (2019) "Chastnyi punkt priema nefti [A private oil inflow spot]" Meduza. io, 7 May

Druzenko, E., Savushkin, S. and Chernov, M. (2002) "Politicheskie vektory novykh nefteprovodov [The political directions of new pipelines]" Neft' $i$ Kapital, April

Dyner, A.M. (2010) "Is Russia getting closer to taking over Belarusian refineries?" Eastweek, 3 February 
Eastweek (2011) "Russian Federation: Is the Burgas-Aleksandroupolis pipeline plan close to collapse?" Eastweek, 23 February

Embassy Astana (2008) Kazakhstan: Timur Kulibayev discusses oil transportation and Georgia Investments, 08ASTANA2081/Wikileaks \#174382. Issue date 20 October 2008. Cablegate [online]. (Published by Wikileaks 1 September 2011). Available from: https:// wikileaks.org/plusd/cables/08ASTANA2081_a.html [Accessed 1 April 2019]

Embassy Bratislava (2006a) Putin to Slovakia - Why would you want to own an empty pipeline?!, 06BRATISLAVA911/Wikileaks \#85946. Issue date 16 November 2006. Cablegate [online]. (Published by Wikileaks 1 September 2011). Available from: https:// wikileaks.org/plusd/cables/06BRATISLAVA911_a.html [Accessed 1 April 2019]

Embassy Bratislava (2006b) Russians waiting for clock to run out on Transpetrol, 06BRATISLAVA972/Wikileaks \#89956. Issue date 18 December 2006. Cablegate [online]. (Published by Wikileaks 1 September 2011). Available from: https://wikilea ks.org/plusd/cables/06BRATISLAVA972_a.html [Accessed 1 April 2019]

Embassy Bratislava (2006c) Slovakia pursues Transpetrol through murky legal waters, 06BRATISLAVA816/Wikileaks \#80988. Issue date 6 October 2006. Cablegate [online]. (Published by Wikileaks 1 September 2011). Available from: https://wikilea ks.org/plusd/cables/06BRATISLAVA816_a.html [Accessed 1 April 2019]

Embassy Moscow (2006) Russian oil to Lithuania - Mixing revenge and business, 06MOSCOW9482/Wikileaks \#76658. Issue date 30 August 2006 [online]. (Published by Wikileaks 8 September 2011). Available from: https://wikileaks.org/plusd/ cables/06MOSCOW9482_a.html [Accessed 13 February 2019]

Embassy Vilnius (2006) Two Russian oil suppliers cancel July crude shipments to Lithuanian refinery, 06VILNIUS618/Wikileaks \#70128. Issue date 3 July 2006 [online]. (Published by Wikileaks 1 September 2011). Available from: https://wikilea ks.org/plusd/cables/06VILNIUS618_a.html [Accessed 13 February 2019]

Embassy Warsaw (2005) Polish pipeline company finalizing a business plan for Odessa-Brody-Gdansk, still looking for Chevron support, 05WARSAW1282/Wikileaks \#28330. Issue date 8 March 2005. Cablegate [online]. (Published by Wikileaks 1 September 2011). Available from: https://wikileaks.org/plusd/cables/05WAR SAW1282_a.html [Accessed 1 April 2019]

Embassy Warsaw (2006) Poland's PKN Orlen discusses Mazeikiu Nafta, Kazakhstan, Azerbaijan, Odessa-Brody, 06WARSAW2008/Wikileaks \#78600. Issue date 15 September 2006. Cablegate [online]. (Published by Wikileaks 1 September 2011). Available from: https://wikileaks.org/plusd/cables/06WARSAW2008_a.html [Accessed 1 April 2019]

Eremenko, A. (2011) "Energorynok: 20 let (ne) zavisimosti [The energy market: 20 years of (in) dependence]" Zerkalo nedeli, 26 August

FGBU Administratsiya morskikh portov Baltiiskogo morya (2019) "Arkhiv dannykh po gruzooborotu [Data archive on turnover of goods]" [online]. (St Petersburg: FGBU Administratsiya morskikh portov Baltiiskogo morya). Available from: http s://www.pasp.ru/arhiv [Accessed 9 May 2019]

Fokina, E. (2006) "TEK. Bol'shaya proverka [The fuel and energy complex. A major examination]" Profil', 15 May, pp.38-39

Fuller, L. (1995) "Azerbaijan: The "Near Abroad" Transitions Online, 28 April

Gabuev, A. et al. (2010) "Dmitrii Medvedev ogranichil Azerbaidzhan [Dmitrii Medvedev limits Azerbaijan]" Kommersant, 4 September, p.1

Gavrish, O. (2003) "TNK razvernula ukrainskuyu trubu [TNK unrolls a Ukrainian pipeline]" Vedomosti, 27 May 
Gavshina, O. (2008) "BP vyzhivayut iz KTK [BP is being driven out of CPC]" Gazeta, 20 November, p. 12

Gavshina, O. (2011) "Tanker vygodnee truby [A tanker is more profitable than a pipeline]" Vedomosti, 16 February, p.7

Gavshina, O. and Reznik, I. (2010) "Milliardy iz truby [Billions out of the pipe]" Vedomosti, 17 November, p.1

Gazprom (2016) Vnutrennyaya sila. Finansovyi otchet PAO "Gazprom” za 2016 god [Internal strength. Financial statement for the public company Gazprom for 2016] (Moscow: Gazprom)

Gordeev, I. (2007) "Transneft" v bezopasnosti [Transneft is safe]" Vremya novostei, 16 October, p. 8

Gorelov, N. and Tomashevskaya, O. (2007) "Podal'she ot Lukashenko [A little farther from Lukashenko]" Vremya novostei, 6 February, p.1

Gorshkova, A. (2007) "Vainshtok umeet ubezhdat" ['Vainshtok knows how to convince']" Vremya novostei, 20 September, p.8

Government Resolution No. 512 (27/05/1998) Voprosy aktsionernoi kompanii po transportu nefti "Transneft", [Questions concerning the shareholding oil transport company Transneft] (Moscow: The Government of the Russian Federation)

Government Resolution No. 810 (14/08/1993) Ob uchrezhdenii aktsionernoi kompanii po transportu nefti "Transneft"' [On the foundation of the shareholding company in oil transport 'Transneft'] (Moscow: The Government of the Russian Federation)

Government Resolution No. 1325 (16/10/1997) O proektirovanii, stroitel'stve $i$ ekspluatatsii Baltiiskoi truboprovodnoi sistemy [On project development, construction and exploitation of the Baltic Pipeline System] (Moscow: The Government of the Russian Federation)

Government Resolution No. 1333 (17/10/1997) O merakh po obospecheniyu gosudarstvennogo upravleniya zakreplennymi $v$ federal'noi sobstvennosti aktsiyami aktsionernoi kompanii po transportu nefti "Transneft" [On measures to guarantee state management of the federal property of shares in the shareholding oil transport company Transneft] (Moscow: The Government of the Russian Federation)

Guliyev, F. and Arkhrarkhodjaeva, N. (2008) Transportation of Kazakhstani Oil via the Caspian Sea (TKOC). Arrangements, actors and interests. RUSSCASP Working Paper. (Lysaker, Norway/Bremen, Germany: Fridtjof Nansen Institute)

Gustafson, T. (2012) Wheel of Fortune. The battle for oil and power in Russia (Cambridge, MA/London: The Belknap Press of Harvard University Press)

Harding, L. (2007) "Putin, the Kremlin power struggle and the \$40bn fortune" The Guardian, 21 December, p.1

IA FK-Novosti (2009) 'Transneft' rassmatrivaet vozmozhnost' perenapravleniya v Novorossiisk vsego neftyanogo tranzita Kazakhstana [Transneft is looking into the possibility of sending all Kazakhstan's oil transit through Novorossiisk]" Kommersant, 5 June

IEA (2002) Russia energy survey 2002 (Paris: International Energy Agency)

IEA (2015) Online Data Services, Issue date [online]. (Published by International Energy Agency 2015). Available from: http://www.iea.org/statistics/ [Accessed 6 October 2015]

Ignatova, M. (2003) "Kachai nazad! 'Transneft” uvelichit eksport za schet Ukrainy [Pump it back! Transneft expands export at the expense of Ukraine]" Izvestiya, 31 May, p.6

Inozemtsev, G. (1999) "Kogo ne ustraivaet 'baltiiskii proekt'? [Who isn't happy with the 'Baltic project'?]” Rossiiskaya gazeta, 4 August 
Ivanov, N. (1997) “Transneft' sobiraet druzei [Transneft gathers its friends]" Segodnya, 5 December

Ivanova, S., Surzhenko, V. and Derbilova, E. (2008) "Beskontrol'nye milliardy [Uncontrolled billions]" Vedomosti, 24 March

Ivzhenko, T. (2004) "Kiev gotov reshit' vse problemy s Moskvoi do vyborov prezidenta. Ukraina namerena stat' osnovnym strategicheskim napravleniem tranzita rossiiskoi nefti [Kiev is ready to solve all problems with Moscow before the presidential elections. Ukraine wants to be the primary strategic route for Russian oil transit]" Nezavisimaya gazeta, 23 June, p.5

Kanevskaya, P. (2003) "Kon"yunktura ne dlya nas. Rossiiskie neftyanye kompanii ne uspeyut vospol'zovat'sya blagopriyatnoi situatsiei na mezhdunarodnykh rynkakh [Not our state of the market. Russian oil companies will not succeed in taking advantage of the favourable conditions in international markets]" Nezavisimaya gazeta, 13 January, p.4

Karagiannis, E. (2002) Energy and security in the Caucasus (London/New York: RoutledgeCurzon)

Kaz'min, D. (2012) "Ne ot chistoi pribyli [Not from clean profits]" Vedomosti, 10 August

Kazakhstan-China Pipeline LLP (2014) Kazakhstan-China Pipeline LLP Financial statements for year ended 31 December 2014 with independent auditor's report (Almaty: Kazakhstan-China Pipeline LLP)

Kazakhstan-China Pipeline LLP (2016) Kazakhstan-China Pipeline LLP Financial statements for year ended 31 December 2016 with independent auditor's report (Almaty: Kazakhstan-China Pipeline LLP)

Kazakhstan-China Pipeline LLP (2018) Kazakhstan-China Pipeline LLP Financial statements for year ended 31 December 2018 with independent auditor's report (Almaty: Kazakhstan-China Pipeline LLP)

KazMunayGaz (2012) "Transportirovka nefti [Oil transportation]" [online]. 13 April (Astana: KazMunayGaz). Available from: http://www.kmg.kz/manufacturing/oil/ [Accessed 30 April 2012]

Kezik, I. (2007) “'Druzhba' zakryta navek [Druzhba is forever closed]” Gazeta, 24 April, p.19

Khalip, I. (2007) “'Druzhba' so vsemi vytekayushchimi [Druzhba and all its meanderings]" Novaya gazeta, 11 January, p.9

Khikmatov, T. (2001) "Morskoi status. Rossiya ukreplyaet svoi pozitsii na Baltiiskom more [Naval position. Russia strengthens its positions on the Baltic Sea]" Izvestiya, 26 December, p.5

Kolesnikov, A. (2006) "Baikalspasaigrup [BaikalSaveGroup]" Kommersant, 27 April, p.1

Kommersant (2010) "Rosneft" i "Transneft" protiv svoei privatizatsii [Rosneft and Transneft against their own privatisation]" Kommersant, 27 July

Kommersant-Vlast' (1999) "Nedelya 14.09.-20.09 1999” Kommersant-Vlast', 21 September, p. 20

Komsomol'skaya Pravda Kazakhstan (2007) "AO KazTransOIL': Neft' idet zadannym marshrutom [JSC KazTransOil: Oil flows on the set route]" Komsomol'skaya Pravda Kazakhstan, 5 October

Korytina, E. (2010) "Uzakonennaya neft' [Legalised oil]" $R B C$ Daily, 28 September

Kozlov, D. and Dzhumailo, A. (2017) “"Transneft' gotovyat k privatizatsii [Transneft is prepared for privatization]" Kommersant, 19 July, p.8

Kravchenko, E. (2003) "Ventspils prosit russkogo syr'ya. Latviiskii port mozhet ne vyderzhat' blokadu [Ventspils asks for Russian crude. The Latvian port may not endure the blockade]" Izvestiya, 14 March, p.6 
Kulikov, S. (2007) "Berlin proverili na energozavisimost' [Berlin is checked for energy independence]" Nezavisimaya gazeta, 27 August, p.1

Kupchinsky, R. (2006) "Russia: Moscow extends its pipeline web" [online]. 23 June (Prague: Radio Free Europe/Radio Liberty). Available from: http://www.rferl.org/ content/article/1069413.html [Accessed 1 April 2019]

Kutuzova, M. (2017) "Uspekhi i pechali Transnefti [Transneft's successes and sorrows]" Neftegazovaya vertikal', Nos 1-2, pp.70-72

Lavrov, A. (2007) “'Druzhba' - za den'gi [Friendship at a price]” Gazeta, 9 January, p.1

Lee, R. (2013) "The Russian Far East: Opportunities and challenges for Russia's window on the Pacific", Orbis, 57 (2): 314-324

Makarkin, A. (2007a) "Eksportnye marshruty uglevodorodov [Hydrocarbon export routes]" Neft' i Kapital, June

Makarkin, A. (2007b) "Neftyanoi general [Oil general]" Neft' $i$ Kapital, November

Malkova, I. (2009) "Komu pomogaet 'Transneft" [Who does Transneft help]" Vedomosti, 7 May

Malkova, I. (2010) "Shareholder wins ruling against Transneft over charity funds" The Moscow Times, 7 May

Markus, U. (1995) "Belarus: Heading off an energy disaster" Transition, 14 April

Markus, U. (1996) "Energy: Ukraine and Belarus seek help abroad" Transition, 3 May

Marochkin, V. (2012) "Trassa nezavisimosti [The route of independence]" Truboprovodnyi transport nefti, 2012 (1-2), pp.14-25

Martynov, K. (2007) "Vozvrashchenie rezidenta [The return of the resident]" Kommersant (Business Guide), 20 November

Martynov, K. (2008) "Pustaya truba [The empty pipeline]" Kommersant (Business Guide), 24 March

Mazneva, E. (2007) "Upravlyat' konkurentom [To manage a competitor]" Vedomosti, 27 June

Mel'nikov, K. (2009) "KTK uzhe rasshiryaetsya [CPC is already being extended]" Vremya novostei, 17 December, p.8

Mel'nikov, K. (2015) "Glave 'Transnefti' dali eshche pyat' let [The head of Transneft is given another five years]" Kommersant, 27 April, p.7

Meshcherin, A. (2014) "Pir v preddverii chumy? [A feast on the eve of plague?]" Neftegazovaya vertikal', Nos 13-14, pp.74-81

Ministry of Energy (2009) Energeticheskaya strategiya Rossii na period do 2030 goda [Russia's energy strategy for the period to 2030] (Moscow: Institute of Energy Strategy)

Ministry of Industry and Trade (2003) Energeticheskaya strategiya Rossii na period do 2020 goda [Russia's Energy Strategy for the period to 2020] (Moscow: Ministerstvo promyshlennosti i torgovli)

Mishin, V. (2000) "“Transneft” vryad li poluchit den'gi iz Baku [Transneft not likely to get any money from Baku]" Vremya $M N, 7$ July

Mishin, V. (2017) "Neft' Kazakhstana zhdut v Baku [Baku waits for Kazakhstan's oil]" Neftegazovaya vertikal', Nos 1-2, pp.94-97

Mokrousova, I. and Reznik, I. (2013) "Chelovek s resursom [A resourceful person]" Vedomosti, 21 January, p.1

Mordyushenko, O. (2016) "Dividendy 'Transnefti' rassmotryat po sushechestvu [Transneft's dividends will be judged on substance]" Kommersant, 19 September, p.9

Mordyushenko, O. (2017) “Aktsii 'Transnefti' zhdut yuanei [Transneft's shares are waiting for yuans]" Kommersant, 4 August, p.9 
Nazarbaev, N. (1997) "Pochemu Nazarbaev nedovolen Rossiei [Why Nazarbaev is unhappy with Russia]" Novaya gazeta, 26 May

Neft' i Kapital (1998) "Dmitrii Savel'ev: 'Seichas net smysla privatizirovat' Transneft" [Dmitrii Savelev: 'There is no point now in privatising Transneft']" Neft' i Kapital, October

Neft' i Kapital (2002a) "Imangali Tasmagambetov: 'Kazakhstan stoit na pozitsiyakh postroeniya mnogovektornoi neftetransportnoi sistemy' [Imangali Tasmagambetov: 'Kazakhstan maintains its position of building a multivector oil transport system']" Neft' i Kapital, September

Neft' $i$ Kapital (2002b) "Kachestvo opredelyaet napravlenie [The quality determines the direction]" Neft' $i$ Kapital, September

Neft' $i$ Kapital (2002c) "Torzhestvo zdravogo smysla [A triumph for common sense]" Neft' i Kapital, October

Neft' $i$ Kapital (2002d) "Novaya severo-zapadnaya kontseptsiya [A new northwest concept]" Neft' i Kapital, September

Neft' i Kapital (2002e) "Tyazhelaya neft' mozhet pomoch' Ventspilsu [Heavy crude may help Ventspils]" Neft' $i$ Kapital, January

Neft' $i$ Kapital (2002f) "Truba chetyrekh [The pipeline of four]" Neft' $i$ Kapital, December

Neft' i Kapital (2003a) "Yurii Medvedev: 'Polovina FGUP segodnya absolyutno ne nuzhny gosudarstvu' [Yurii Medvedev: 'Half the federal state unitary enterprises are today absolutely not needed by the state']" Neft' $i$ Kapital, March

Neft' i Kapital (2003b) "Sergei Maslov: 'My rabotaem nad razvitiem sistemy magistral'nykh produktoprovodov' [Sergei Maslov: 'We're working on the development of a system of trunk oil product pipelines']" Neft' $i$ Kapital, July-August

Neft' $i$ Kapital (2003c) "Konkurent ne dremlet [The competitor is watching]" Neft' $i$ Kapital, May

Neft' i Kapital (2003d) "Yanis Adamsons: 'Nam pryamo zayavili - problema v tom, chto v Ventspilse net rossiiskogo kapitala' [Janis Adamsons: 'We were told outright: the problem is that there is no Russian capital in Ventspils']" Neft' $i$ Kapital, April

Neft' $i$ Kapital (2003e) "Bol'shie nadezhdy [Great hopes]" Neft' $i$ Kapital, June

Neft' $i$ Kapital (2003f) "Gordiev uzel protivorechii [A Gordian knot of contradictions]" Neft' i Kapital, May

Neft' $i$ Kapital (2003g) "Truba v Podnebesnuyu [A pipeline to the land under the heavens]" Neft' $i$ Kapital, May

Neft' $i$ Kapital (2004a) "Kaspiiskii truboprovodnyi konsortsium [The Caspian Pipeline Consortium]" Neft' i Kapital, October

Neft' $i$ Kapital (2004b) "Baltiiskaya truboprovodnaya sistema [The Baltic Pipeline System]" Neft' i Kapital, October

Neft' i Kapital (2004c) "Transneft" Neft' i Kapital, October

Neft' $i$ Kapital (2004d) "I vse-taki revers! [Reversed, after all]" Neft' $i$ Kapital, September

Neft' i Kapital (2004e) "Ventspils" Neft' i Kapital, October

Neft' i Kapital (2004f) "Omishal' pobezhdaet Odessu [Omisalj is vanquishing Odesa]" Neft' i Kapital, March

Neft' $i$ Kapital (2004g) "Poltora goda bez truby [One and a half year without a pipeline]" Neft' i Kapital, June

Neft' $i$ Kapital (2004h) "Privilegirovannye aktsii Transnefti [Transneft's privileged shares]" Neft' i Kapital, October 
Neft' i Kapital (2004i) "Sukhodol'naya-Rodionovskaya" Neft' $i$ Kapital, October Neft' i Kapital (2004j) "Mazheikyu nafta [Mazeikiu Nafta]" Neft' i Kapital, October

Neft' i Kapital (2004k) "Vagit Alekperov" Neft' i Kapital, October

Neft' i Kapital (2005a) "Semen Vainshtok: 'Transneft" predlagaet sokratit' eksport nefti. Protsentov na 50-60' [Semyon Vainshtok: 'Transneft proposes to reduce oil export. By 50 to 60 per cent']" Neft' $i$ Kapital, December

Neft' $i$ Kapital (2005b) 'Strana-khozyaika stavit usloviya [The host country sets conditions]" Neft' $i$ Kapital, September

Neft' $i$ Kapital (2005c) "Mechty sbyvayutsya [Dreams are coming true]" Neft' $i$ Kapital, October

Neft' $i$ Kapital (2005d) "Ventspils v ozhidanii peremen [Ventspils is waiting for change]" Neft' i Kapital, March

Neft' i Kapital (2005e) "Vse v Dzheikhan! [All to Ceyhan!]" Neft' i Kapital, December

Neft' $i$ Kapital (2006a) "'Energeticheskii orel' priletel [The energy eagle has landed]" Neft' i Kapital, June

Neft' $i$ Kapital (2006b) "Proyasnyayutsya perspektivy [The perspectives are becoming clear]" Neft' i Kapital, September

Neft' i Kapital (2006c) "Eto tol'ko nachalo [This is just the beginning]" Neft' i Kapital, October

Neft' i Kapital (2006d) "Kak obychno, 'v sleduyushchem godu' [As usual, 'next year']" Neft' i Kapital, October

Neft' $i$ Kapital (2006e) "Svoya ruka - vladyka [One's own hand is sovereign]" Neft' $i$ Kapital, December

Neft' $i$ Kapital (2006f) "Trebuetsya neft' rossiiskogo proizvodstva [Wanted: Russianproduced oil]" Neft' i Kapital, January-February

Neft' i Kapital (2006g) "'Druzhba' otkhodit na zadnii plan [Druzhba is receding into the background]" Neft' $i$ Kapital, September

Neft' i Kapital (2006h) "Kuryk ne nuzhen? [Is Kuryk superfluous?]" Neft' i Kapital, January-February

Neft' $i$ Kapital (2007a) "Pora opredelyat'sya [It's time to make up one's mind]" Neft' $i$ Kapital, September

Neft' $i$ Kapital (2007b) "Dlya strakhovki [Just in case]" Neft' $i$ Kapital, March

Neft' $i$ Kapital (2007c) "Truba ne terpit pustoty [A pipe cannot be empty]" Neft' $i$ Kapital, March

Neft' i Kapital (2007d) "Novoe litso 'Severa' [Sever's new face]" Neft' i Kapital, April

Neft' $i$ Kapital (2007e) "Al'ternativno, no dorogo [Alternatively, but expensively]" Neft' i Kapital, June

Neft' i Kapital (2007f) "Semen Vainshtok: 'V blizhaishie neskol'ko let nashim prioritetom budet VSTO' [Semyon Vainshtok: 'In the next few years, ESPO will be our priority']" Neft' i Kapital, March

Neft' i Kapital (2008a) "BTS-2 [BPS-2]" Neft' $i$ Kapital, August

Neft' $i$ Kapital (2008b) "Semen Vainshtok [Semyon Vainshtok]" Neft' $i$ Kapital, August

Neft' $i$ Kapital (2008c) "Vse ne tak, rebyata... [This isn't all OK, guys...]" Neft' $i$ Kapital, March

Neft' $i$ Kapital (2009a) "Kitaiskii pauk [The Chinese spider]" Neft' $i$ Kapital, November 
Neft' i Kapital (2009b) “Kontekst. Gunvor konsolidiruet nefteperevalku v Ust'-Luge [Context. Gunvor is consolidating oil transhipment at Ust-Luga]" Neft' $i$ Kapital, April

Neft' $i$ Kapital (2009c) "Ty mne - ya tebe [You give me and I give you]" Neft' $i$ Kapital, December

Neft' $i$ Kapital (2010a) "Prizraki proshlogo 'Transnefti' [Ghosts from Transneft's past]" Neft' $i$ Kapital, June

Neft' i Kapital (2010b) "Chistoe delo [A clear case]" Neft' i Kapital, September

Neft' i Kapital (2011a) "Slaboe zveno [The weak link]" Neft' $i$ Kapital, October

Neft' i Kapital (2011b) "Ot kazhdogo - po sposobnostyam [From each on the basis of ability]” Neft' i Kapital, November

Neft' $i$ Kapital (2011c) "Kaspiiskii priliv [A Caspian influx]" Neft' $i$ Kapital, April

Neft' i Kapital (2011d) "Politicheskii marshrut [The political route]" Neft' i Kapital, August

Neft' $i$ Kapital (2012a) "Ne ochen'-to i khotelos'! [Not that we wanted it in the first place!]” Neft' $i$ Kapital, January-February

Neft' $i$ Kapital (2012b) "Khoteli kak luchshe... [They wanted the best...]" Neft' $i$ Kapital, April

Neft' i Kapital (2012c) "Smena orientatsii [A change of orientation]" Neft' i Kapital, January-February

Neftegazovaya vertikal' (2012) "Statistika [Statistics]" Neftegazovaya vertikal', No. 3, p.87

Neftegazovaya vertikal' (2013) "Statistika [Statistics]" Neftegazovaya vertikal', No. 3, p.115

Neftegazovaya vertikal' (2014a) "Statistika [Statistics]" Neftegazovaya vertikal', No. 3, p.83

Neftegazovaya vertikal' (2014b) "Truboprovody. Sil'noe zveno [Pipelines. The strong link]” Neftegazovaya vertikal', No. 23-24, pp.82-87

Neftegazovaya vertikal' (2015) "Statistika [Statistics]" Neftegazovaya vertikal', No. 3, p.75

Neftegazovaya vertikal' (2016a) "Statistika [Statistics]" Neftegazovaya vertikal', No. 3 4, p. 123

Neftegazovaya vertikal' (2016b) "Mirnaya ekspansiya [Peaceful expansion]" Neftegazovaya vertikal', No. 22, pp.32-39

Neftegazovaya vertikal' (2017a) "Ne tol'ko megaproekty [Not just mega-projects]" Neftegazovaya vertikal', No. 9, pp.52-56

Neftegazovaya vertikal' (2017b) "Statistika [Statistics]" Neftegazovaya vertikal', No. 34, p. 127

Nezavisimaya gazeta (2012) "Sammit ATES ne opravdal ozhidanii [The APEC summit did not deliver on expectations]", Nezavisimaya gazeta, 29 December, p. 5

Nikolaev, N. (2003) "Truba u viska [A pipe at the temples]" Rossiiskie vesti, 29 January, p.7

Oilcapital.ru (2002) 'Neftenalivnyi port Primorsk rabotaet na polnuyu moshchnost' [The oil port Primorsk is working to full capacity]" [online]. 11 July (Moscow: IG Industriya). Available from: https://oilcapital.ru/news/markets/11-07-2002/neftenalivnoy-port-prim orsk-rabotaet-na-polnuyu-moschnost [Accessed 12 April 2019]

Oilcapital.ru (2009) "'Transneft" ne planiruet povyshat' tarif na prokachku nefti v blizhaishee vremya [Transneft does not plan to increase the tariff on oil transport in the near future]" [online]. 19 April (Moscow: IG Industriya). Available from: https://oilcap ital.ru/news/markets/19-05-2009/transneft-ne-planiruet-povyshat-tarif-na-prokachkunefti-v-blizhayshee-vremya [Accessed 1 April 2019]

Oilcapital.ru (2012) "Reiting vliyaniya krupnykh predprinimatelei i top-menedzherov toplivno-energeticheskogo kompleksa $\mathrm{v}$ dekabre $2012 \mathrm{~g}$. [Rating of the influence of major businessmen and top managers in the fuel and energy complex, December 
2012]" [online]. 6 December (Moscow: IG Industriya). Available from: https://oilcapita 1.ru/news/companies/06-12-2012/reyting-vliyaniya-krupnyh-predprinimateley-i-topmenedzherov-tek-v-dekabre-2012-g [Accessed 18 March 2019]

Oilcapital.ru (2013a) "Minenergo RF planiruet do kontsa goda podgotovit' model' 'banka kachestva' nefti [The Energy Ministry plans to prepare a model for a 'quality bank' by the end of the year]" [online]. 18 March (Moscow: IG Industriya). Available from: https://oilcapital.ru/news/markets/18-03-2013/minenergo-rf-planiruet-do-kontsa -goda-podgotovit-model-banka-kachestva-nefti [Accessed 9 May 2019]

Oilcapital.ru (2013b) “"Transneft” otkazalas' ot prorabotki proekta otvoda ot VSTO do Komsomol'skogo NPZ [Transneft refuses to develop the ESPO spur to Komsomol refinery]" [online]. 30 September (Moscow: IG Industriya). Available from: https:// oilcapital.ru/news/transport/30-09-2013/transneft-otkazalas-ot-prorabotki-proekta-otv oda-ot-vsto-do-komsomolskogo-npz [Accessed 3 May 2019]

Oilcapital.ru (2013c) “"Transneft” povysila stoimost' nefteprovoda Kuyumba-Taishet do $120 \mathrm{mlrd}$ rub [Transneft increases cost of Kuyumba-Taishet pipeline to 120 billion rubles]" [online]. 16 September (Moscow: IG Industriya). Available from: https:// oilcapital.ru/news/transport/16-09-2013/transneft-povysila-stoimost-nefteprovoda-kuy umba-tayshet-do-120-mlrd-rub [Accessed 3 May 2019]

Oilcapital.ru (2013d) "Tarify 'Transnefti' v 2014 g. mogut byt' zamorozheny - gazeta [Transneft's tariffs for 2014 may be subject to freeze - newspaper]" [online]. 26 September (Moscow: IG Industriya). Available from: https://oilcapital.ru/news/ma rkets/26-09-2013/tarify-transnefti-v-2014-g-mogut-byt-zamorozheny-gazeta [Accessed 3 May 2019]

Oilcapital.ru (2013e) "Rasshirit' VSTO dlya 'Rosnefti' mozhno za schet povysheniya tarifa dlya kompanii - Novak [Novak: ESPO may be expanded for Rosneft at company's expense]" [online]. 2 July (Moscow: IG Industriya). Available from: https:// oilcapital.ru/news/transport/02-07-2013/rasshirit-vsto-dlya-rosnefti-mozhno-za-schetpovysheniya-tarifa-dlya-kompanii-novak [Accessed 3 May 2019]

Oilcapital.ru (2013f) "Kazakhstan utverdil tarif dlya tranzita nefti iz RF v Kitai [Kazakhstan confirms tariff for oil transit from Russia to China]" [online]. 27 December (Moscow: IG Industriya). Available from: https:/oilcapital.ru/news/exp ort/27-12-2013/kazahstan-utverdil-tarif-dlya-tranzita-nefti-iz-rf-v-kitay [Accessed 3 May 2019]

Oilcapital.ru (2014) "Nefteprovody Kazakhstana obespechat transportirovku vsei dobyvaemoi v strane nefti - general'nyi direktor AO "KazTransOil” [KazTransOil General director: Kazakhstan's oil pipelines sufficient for transport of all oil produced in country]" [online]. 21 October (Moscow: IG Industriya). Available from: https://oilcapital. ru/news/transport/21-10-2014/nefteprovody-kazahstana-obespechat-transportirovkuvsey-dobyvaemoy-v-strane-nefti-generalnyy-direktor-ao-kaztransoyl [Accessed 3 May 2019]

Oilcapital.ru (2016) "Reiting vliyaniya krupnykh predprinimatelei i top-menedzherov toplivno-energeticheskogo kompleksa v marte $2016 \mathrm{~g}$. [Rating of the influence of major businessmen and top managers in the fuel and energy complex, March 2016]" [online]. 29 March (Moscow: IG Industriya). Available from: https:/oilcapital.ru/ news/companies/29-03-2016/reyting-vliyaniya-krupnyh-predprinimateley-i-top-menedz herov-toplivno-energeticheskogo-kompleksa-v-marte-2016-g [Accessed 20 February 2019]

Oilcapital.ru (2017) “Transneft": ideyu banka kachestva nefti slozhno realizovat' [Transneft: The idea of a quality bank is difficult to implement]" [online]. 28 
December 2017 (Moscow: IG Industriya). Available from: https://oilcapital.ru/ news/markets/28-12-2017/transneft-ideyu-banka-kachestva-nefti-slozhno-realizovat [Accessed 25 April 2019]

Oliphant, R. (2010) "Putin orders openness at Transneft" The Moscow Times, 25 October, p.1

Osetinskaya, E. (1999) "Neftyaniki ne khotyat svyazyvat'sya s Chechnei [The oilmen do not want to associate with Chechnya]" Segodnya, 9 October

Osetinskaya, E. (2000a) "Tumannyi BTS [Foggy BPS]" Vedomosti, 11 February

Osetinskaya, E. (2000b) "Mintopenergo zhelaet znat' [The Fuel and Energy Ministry wants to know]" Vedomosti, 24 February

Osetinskaya, E. (2000c) "U Minenergo zabrali trubu [Pipelines taken away from the Energy Ministry]" Vedomosti, 9 November

Osetinskaya, E. (2000d) "Khristenko vzyalsya za trubu [Khristenko got busy with the pipelines]" Vedomosti, 24 November

Osetinskaya, E. (2001) "Eksport gotovyat k torgam [Export prepared for sale]" Vedomosti, 27 April

Osetinskaya, E. and Velikanov, S. (1999) "Truby goryat... [The pipes are burning...]" Segodnya, 17 September

OzForex (2019) "Yearly average rates" [online]. (Sydney: OzForex). Available from: https://www.ofx.com/en-au/forex-news/historical-exchange-rates/yearly-average-ra tes/ [Accessed 30 April 2019]

Paramonov, S. (2001) "Rynochnye obstoyatel'stva. Rossiya poluchila novoe 'okno v Evropu' [Market conditions. Russia received a new 'window to Europe']" Rossiiskaya gazeta, 17 August, p.26

Petrov, N. and Titkov, A. (1999) Nachalo kampanii [The beginning of the campaign] (Moscow: Gendalf)

Poluektov, N. (1999) "Vzyatie 'Transnefti' [The conquer of Transneft]" Kommersant, 22 September, p. 3

Pravosudov, S. (2003) "Vagit Alekperov: 'Otkuda vy znaete, chto Kukuru ukrali beznakazanno?' [Vagit Alekperov: 'How do you know that Kukura was kidnapped with impunity?"” Russkii Fokus, 14 April

Prime-TASS (2006) "Pravitel'stvo RF utverdilo rekomendatsii federal'nym vedomstvam v otnoshenii pozitsii gosaktsionera po voprosam vyplaty dividendov i raspredeleniya pribyli [The Russian government has confirmed its recommendations to federal agencies on the state's position on dividends payouts and profit distribution]" Prime-TASS, 1 June

Primorskii okeanarium (2019) "Primorskii okeanarium - odin iz krupneishchikh nauchno-poznavatel'nykh kompleksov mira [The Primore ocean centre: One of the largest scientific educational complexes in the world]". Available from http://primocea n.ru/primorskiy-okeanarium-odna-iz-samyh-cennyh-i-interesnyh-zhemchuzhin-kraya. html [Accessed 10 May 2019]

Protsenko, A. (1998) “Chetvertaya opora Rossii [Russia's fourth buttress]” Trud, 20 October

Pynnöniemi, K. (2008) New road, new life, New Russia. Ph.D. thesis, University of Tampere

Quiring, M. (2007) "Man sollte die aktive Rolle Putins nicht überschätzen [One shouldn't overestimate Putin's active role]" Die Welt, 12 November, p.5

Rahimov, R. (2019) "Turkmenistan redirects its oil export flows from Azerbaijan to Russia” Eurasia Daily Monitor, 25 February 
RBK (2018) RBK 500: Reiting rossiiskogo biznesa [RBK 500: The Russian Business Rating] [online]. Moscow. Available from: https://www.rbc.ru/rbc500/ [Accessed 23 November 2018]

Rebrov, D. (2005) "Mazeikiu Nafta lishili kazakhskoi nefti [Mazeikiu Nafta is deprived of Kazakh oil]" Vremya novostei, 18 November, p. 8

Rebrov, D. (2006) "Administrativnoe preimushchestvo [Administrative advantage]" Vremya novostei, 13 February

Rebrov, D. (2008) "Sergei Maslov ushel na birzhu [Sergei Maslov went to the exchange]" Kommersant, 3 October, p.17

Rebrov, D. (2009a) "'Stroit' mozhno chto ugodno, no tarif togda budet bezumnyi' ['You can build anything, but the tariff then becomes insane']" Kommersant, 3 December, p. 14

Rebrov, D. (2009b) "Uspokoili spetskorrespondenta otdela biznesa Denisa Rebrova [The business section's special correspondent Denis Rebrov is reassured]" Kommersant, 10 February, p.9

Reuters News (1994) "Russia's Gazprom in oil pipeline deal with Greece" Reuters, 15 September

Reznik, I. (2000a) “'LUKoil' oboshel 'Transneft' [Lukoil gets round Transneft]" Kommersant, 8 September, p.4

Reznik, I. (2000b) “"My eshche ne znaem, kak delit' tarif' ['We still do not know how to divide the tariff]" Kommersant, 8 September, p.4

Reznik, I. (2001) “Interv'yu: Semen Vainshtok, prezident transportnoi kompanii 'Transneft" [Interview: Semyon Vainshtok, president of the transport company Transneft]" Vedomosti, 25 October

Reznik, I. (2002a) “Interv'yu: Semen Vainshtok, prezident 'Transnefti' [Interview: Semyon Vainshtok, Transneft's president]" Vedomosti, 14 October

Reznik, I. (2002b) “"Transneft'-kontroler [Transneft the controller]" Vedomosti, 3 June

Reznik, I. (2003) "Interv'yu: Semen Vainshtok, prezident kompanii 'Transneft' [Interview: Semen Vainshtok, president of Transneft]" Vedomosti, 26 November

Reznik, I. and Binchuk, P. (2000) "Putin podygral Alekperovu [Putin played up to Alekperov]" Kommersant, 11 February

RFE/RL (1997) "RFE/RL Newsline" Radio Free Europe/Radio Liberty, 14 November RFE/RL (1999) "RFE/RL Newsline" Radio Free Europe/Radio Liberty, 27 September Romanova, L. (1999) 'Mintop obvinyaet eks-prezidenta 'Transnefti' [The Fuel Ministry is accusing the ex-president of Transneft]" Nezavisimaya gazeta, 2 November, p.1

Romanova, L. (2000) "Krizis ukrainskoi nezavisimosti [A crisis in Ukrainian independence]" Nezavisimaya gazeta, 25 January

Romanova, O., Volobuyev, I. and Useinov, A. (1997) "Rossiya otkazalas' ot transportirovki azerbaidzhanskoi nefti cherez Chechnyu [Russia refuses to transport Azerbaijani oil across Chechnya]" Segodnya, 5 February

Rosbalt (2007) "Transneft" teryaet interes k nefteprovodu Khar'yaga-Indiga [Transneft loses interest in Khar'yaga-Indiga pipeline]" [online]. 6 January 2007 (Moscow/ St Petersburg: Rosbalt). Available from: http://www.rosbalt.ru/main/2007/01/06/ 281207.html [Accessed 8 May 2019]

Rutland, P. (1999) “Oil, politics, and foreign policy" in Lane, D. ed., The political economy of Russian oil (Lanham, Maryland: Rowman \& Littlefield), pp.163-188

Samoilova, T. (2000) “'Transneft' teryaet neft' [Transneft is losing oil]” Vedomosti, 31 August 
Sapozhnikov, P. and Ovchinnikov, R. (2000) "Baltiiskaya truboprovodnaya sistema zakryta [The Baltic pipeline system is closed]" Kommersant, 6 September, p.4

Savushkin, S. (2003) "Igry patriotov [Patriots' games]" Neft' i Kapital, September

Savushkin, S. (2007) “Zadvizhka Moskvy [Moscow's catch]” Neft' i Kapital, JanuaryFebruary

Sborov, A. (2000) “Kalyuzhnyi poshel po delu 'LUKoila' v Baku [Kalyuzhnyi goes to Baku on the Lukoil case]" Kommersant, 14 July, p.3

Sharip, F. (2018) "Faced with Chinese expansion, Kazakhstan seeks alternative energy markets" Eurasia Daily Monitor, 30 April

Shevel'kova, O. (2005) “'Kazmunaigaz' ne puskayut v Litvu [KazMunaiGaz is not let into Lithuania]" Gazeta, 18 November, p.21

Shvedko, I. (2002) "Bor'ba za Slavneft' ne zakonchena [The fight for Slavneft is not over]", Mirovaya energeticheskaya politika, 1 (4): 69-71

Siddiky, C.I.A. (2012) Cross-border pipeline arrangements. What would a single regulatory framework look like? (Alphen aan den Rijn: Kluwer Law International)

Sim, L.-C. (2008) The rise and fall of privatization in the Russian oil industry (Basingstoke: Palgrave-Macmillan)

Skornyakova, A. and Skorlygina, N. (2006) "Rossiya nashla komu doverit' KTK [Russia found someone with whom to entrust CPC]" Kommersant, 13 January, p.5

Slyusarenko, S. (1999) "Primakov blagoslovil novye porty na Baltike [Primakov blesses new ports on the Baltic Sea]" Kommersant, 25 February, p.7

Smirnov, G. (1998) “'Svyashchennaya korova' 'Transnefti' [Transneft's sacred cow]" Neft' i Kapital, February

Socor, V. (2007) "Bridgehead in Europe: Kazakhstan acquires Romania's Rompetrol" Eurasia Daily Monitor, 7 September

Socor, V. (2008) "Oil-handling capacities growing and available on Georgia's Black Sea Coast" Eurasia Daily Monitor, 13 February

Socor, V. (2009) "Samsun-Ceyhan pipeline project designed to divert Kazakhstani oil" Eurasia Daily Monitor, 23 October

Socor, V. (2010) "Moscow tightens squeeze on Belarus oil industry" Eurasia Daily Monitor, 15 January

Socor, V. (2012) "Russia completing Baltic Pipeline system construction, reducing Druzhba pipeline flow" Eurasia Daily Monitor, 24 February

Sokolov, A. (1999) "S. i V. sideli na trube [S. and V. sat on a pipe]" Nezavisimaya gazeta - Figury i litsa, 8 October, p.4

Solodovnikova, A. (2013) “'Transneft' delit chuzhie sverkhpribyli [Transneft shares others' superprofits]" Kommersant, 25 November, p.1

Solov'ev, D. (2000) "Proshu slova. Truba nezavisimosti [In one's own words. The pipe of independence]" Profil', 6 November, p.22

SPB Vedomosti (1999) “'I vse-taki v Porvoo!' ['And yet it will go to Porvoo!']” SPB Vedomosti, 23 February

Starinskaya, G. (2010) "Truba za schet neftyanikov [A pipeline at the oilmen's expense]" RBC Daily, 6 September

Statista (2019) "Euro (EUR) to Russian ruble (RUB) average annual exchange rate from 1999 to 2018" [online]. (Hamburg: Statista). Available from: https://www.statista.com/ statistics/412824/euro-to-ruble-average-annual-exchange-rate/ [Accessed 30 April 2019]

Stevens, P. (2009) Transit troubles. Pipelines as a source of conflict. Chatham House Report (London: Chatham House) 
Stolyarov, B. (2000) “Sensatsiya! Podvig Khristenko [Sensation! Khristenko's accomplishment]" Novaya gazeta, 20 November

Stratfor (2005) "Russia: Improving the oil infrastructure", Stratfor [online] (16 August). Available from http://www.stratfor.com/russia_improving_oil_infrastruc ture [Accessed 1 April 2019]

Strel'tsov, A. (1999) "Yuzhnyi marshrut neftyanoi reki [The oil river's southern course]" Ekonomika i zhizn', 22 May

Surzhenko, V. (2007) "Den'gi v obmen na trubu [Money in return for a pipe]" Vedomosti, 20 September

Surzhenko, V. and Reznik, I. (2008) "'Vse ravno, skol'ko stoyat aktsii', - Nikolai Tokarev, prezident 'Transnefti' ['It does not matter how much the shares go for', says Nikolai Tokarev, Transneft's president]" Vedomosti, 18 February

Sysoev, G. and Gankin, L. (1998) "Rossiya ob"yavila Latvii neftyanoi boikot [Russia declares oil boycott on Latvia]" Kommersant, 9 April, p.3

Tkachev, I. (2017) "Schetnaya palata priznala nedostovernym plan Minfina po sboru dividendov [The Audit Chamber finds the Finance Ministry's plan for dividends extraction unreliable]" RBC Daily, 13 October

Tomashevskaya, O. et al. (2007) "Iz-za bat'ki - v peklo [To hell because of Batka]" Vremya novostei, 10 January, p.1

Tovkailo, M. and Biryukov, A. (2010) "Chastnaya ugroza [The private menace]" Vedomosti, 2 August

Transneft-Diaskan (2019) “AO 'Transneft-Diaskan' v 2018 godu vypolnilo diagnostiku bolee 4 tys. kilometrov truboprovodov za rubezhom [Transneft-Diaskan carried out diagnostics of more than $4000 \mathrm{~km}$ pipelines abroad]" [online]. (Moscow: TransneftDiaskan). Available from: https://diascan.transneft.ru/press/news/?id=59611 [Accessed 6 May 2019]

Transneft (2006) Godovoi otchet OAO “AK Transneft” za 2005 god [Annual report for Transneft for 2005] (Moscow: Transneft)

Transneft (2007) Godovoi otchet OAO “AK Transneft" za 2006 god [Annual Report for Transneft for 2006] (Moscow: Transneft)

Transneft (2008) Godovoi otchet za 2007 god [Annual Report for 2007] (Moscow: Transneft)

Transneft (2009a) "Vo vtornik 26 maya prezident OAO "AK Transneft" Nikolai Petrovich Tokarev vstretilsya s zhurnalistami [On Tuesday 26 May Transneft's president, Nikolai Petrovich Tokarev, met with journalists]" [online]. 26 May 2009 (Moscow: Transneft). Available from: http://www.transneft.ru/news/view/id/128/ [Accessed 1 April 2019]

Transneft (2009b) Godovoi otchet za 2008 god [Annual report for 2008] (Moscow: Transneft)

Transneft (2010) Godovoi otchet za 2009 god [Annual report for 2009] (Moscow: Transneft)

Transneft (2011a) Informatsiya ob okazanii blagotvoritel'noi pomoshchi OAO “AK Transneft", v $2011 \mathrm{~g}$. [Information about the rendering of charity aid by Transneft in 2011 (Moscow: Transneft). Available from: http://www.transneft.ru/files/2012-05/ 2Z56Q.x1sTBpubN.pdf [Accessed 1 April 2019]

Transneft (2011b) OAO AK "Transneft". Godovoi otchet za 2010 god [JSC Transneft. Annual report for 2010] (Moscow: Transneft)

Transneft (2014a) "Ustav [Statutes]" [online]. (Moscow: Transneft). Available from: http://transneft.ru/information/104/ [Accessed 1 April 2019] 
Transneft (2014b) "Istoriya [History]" [online]. (Moscow: Transneft). Available from: http://transneft.ru/about/story/ [Accessed 1 April 2019]

Transneft (2018) Godovoi otchet za 2017 god [Annual Report for 2017] (Moscow: Transneft)

Transneft (2019) "Proekty 'Transnefti' v oblasti blagotvoritel'nosti [Transneft's projects in the charity sphere]" [online]. (Moscow: Transneft). Available from: https://www. transneft.ru/social_responsibility/charity/proekti/ [Accessed 10 May 2019]

Transnefteprodukt (2009) Godovoi otchet za $2008 \mathrm{~g}$. [Annual report for 2008] (Moscow: Transnefteprodukt)

Tutushkin, A. (2005) “'Transneft' vmeshalas' v sdelku 'YuKOSa' [Transneft meddles in Yukos's deal]" Vedomosti, 18 November

Tutushkin, A. (2008) "V ocheredi k trube [In line for the pipe]" Vedomosti, 12 March

US Department of the Treasury (2014) "Treasury sanctions Russian officials, members of the Russian leadership's inner circle, and an entity for involvement in the situation in Ukraine" [online]. 20 March 2014 (Washington, DC: US Department of the Treasury). Available from: https://www.treasury.gov/press-center/press-releases/Pa ges/j123331.aspx [Accessed 13 January 2017]

Ubushaeva, K. and Ivankina, E. (2014) "Transneft" bez investtarifa [Transneft without an investment tariff]" RBC Daily, 12 February, p.5

US Office Almaty (2006) Kazakhstan: Kulibayev discusses energy with Ambassador, 06ALMATY1237/Wikileaks \#59752. Issue date 7 April 2006. Cablegate [online]. (Published by Wikileaks 1 September 2011). Available from: https://wikileaks.org/p lusd/cables/06ALMATY1237_a.html [Accessed 1 April 2019]

Useinov, A. and Klasson, M. (1999a) "Transneft" stala zalozhnitsei Chechni [Transneft has become a hostage of Chechnya]" Vremya $M N, 21$ May

Useinov, A. and Klasson, M. (1999b) "Syurprizy dlya 'Transnefti' [Surprises for Transneft]" Vremya $M N, 9$ February

Useinov, A. and Tutushkin, A. (1999) "Nadoelo [Sick of it]" Vremya MN, 21 July

Vainshtok, S. (2000) "Transneft': 46,700 km of Oil Pipelines", International Affairs (Moscow) 46 (2): $44-47$

Vasil'ev, A. and Suchkov, A. (1999) "Prirodnye resursy [Natural resources]" AiF Interfax, 29 January

Vedomosti (1999) "Vainshtok stal tsarem truby [Vainshtok becomes pipeline tsar]" Vedomosti, 17 September

Vedomosti (2000) "Azerbaidzhanu ne khvatilo nefti [Azerbaijan does not have enough oil]" Vedomosti, 12 January

Vedomosti (2003) "'Transneft' khochet kupit' 50\% Ventspils Nafta [Transneft wants to buy $50 \%$ of Ventspils Nafta]" Vedomosti, 11 April

Vedomosti (2017) "Vkrattse [In brief]" Vedomosti, 13 April, p.11

Verezemskii, S. (1998a) "Transneft" stoit messy [Transneft is well worth a mass]" Neft' $i$ Kapital, October

Verezemskii, S. (1998b) "Peremeny v Transnefti [Changes in Transneft]" Neft' i Kapital, August

Vin'kov, A. and Rubanov, I. (2006) "Osobo tsennaya gosudarstvennaya kompaniya [A particularly valuable state company]" Ekspert, 19 June, pp.82-88

Vin'kov, A. et al. (2004) "Tsena bezdeistviya [The cost of doing nothing]" Ekspert, 11 October, pp.38-43

Vinogradova, O. (2015) "Marshruty rossiiskoi nefti [The routes of Russian oil]" Neftegazovaya vertikal', No. 7, pp.56-62 
Vodyanova, M. (1999) "Zashchemlenie neftyanogo nerva [Pinching the oil nerve]" Obshchaya gazeta, 7 October

Vremya $M N$ (1999) "Neft' propala [The oil disappeared]" Vremya $M N, 30$ November

Wikipedia (2019) "Russian Accounting Standards/Rossiiskie standarty bukhgal'terskogo ucheta" [online]. (San Francisco: Wikimedia Foundation). Available from: https://en. wikipedia.org/wiki/Russian_Accounting_Standards [Accessed 1 May 2019]

Yafimava, K. (2011) The transit dimension of EU energy security (Oxford: Oxford University Press for the Oxford Institute for Energy Studies)

Yakoreva, A. (2016) "Chernaya dyra s polovinoi trilliona. Skol'ko deneg skopil 'Rosneftegaz' [A black hole with half a billion. How much money Rosneftegaz accumulated]" Republic (Slon)1 November

Zhiznin, S. (2010) "Nuzhna li Rossii 'Druzhba'? [Does Russia need Druzhba?]" Nezavisimaya gazeta, 9 February, p.11

Zhulebin, E. (1999) "Shchedraya ruka Viktora Kalyuzhnogo [Viktor Kalyuzhnyi's generous hand]" Kommersant-Vlast', 14 September

Zimin, D. (2012) "How can foreign companies influence Russia's economic course? The cases of Finnish firms Fortum and Neste", Post-Soviet Affairs, 28 (2): 209-231

Zotova, E. (2008) "KTK pod kontrolem [CPC under control]" Vedomosti, 5 November

Zuev, A. (2009) "Eshche odin vykhod v Evropu [Yet another outlet to Europe]" Truboprovodnyi transport nefti, 2009 (5): 15-17.

Abrahamyan, G. (2015) "Could Russia spoil Armenia's Iranian investment dreams?" Eurasianet.org, 17 July

Afanasiev, V. (2009) "Sector bridges great divide" Upstream, 20 August

Analiticheskii Tsentr (2016) Trudnosti na puti vostochnogo gazovogo vektora [Difficulties on the road to an eastern gas vector]. Energeticheskii byulleten'. (Moscow: Analiticheskii Tsentr pri Pravitel'stve Rossiiskoi Federatsii/Analytical Center for the Government of the Russian Federation)

Analiticheskii Tsentr (2017) V fokuse: Kazakhstan - chetvert' veka reform [In focus: Kazakhstan - a quarter of a century of reform]. Byulleten' o tekushchikh tendentsiyakh mirovoi ekonomiki. (Moscow: Analiticheskii Tsentr pri Pravitel'stve Rossiiskoi Federatsii/Analytical Center for the Government of the Russian Federation)

APEK (2017) "Reiting vliyaniya krupnykh predprinimatelei i top-menedzherov toplivno-energeticheskogo kompleksa v iyune $2017 \mathrm{~g}$. [Rating of the influence of major businessmen and top managers in the fuel and energy complex, June 2017]" [online]. 29 June (Moscow: Agentstvo politicheskikh i ekonomicheskikh kommunikatsii). Available from: http://apecom.ru/projects/item.php?SECTION_ID=102\& ELEMENT_ID=3803 [Accessed 18 March 2019]

Bagrov, A. (2000) "Kak delitsya Vyakhirev [How Vyakhirev will be divided]" Kommersant, 29 January, p.1

Bakhtadze, R. (2002) "Russian energy giant takes over Georgian gas distribution system" [online]. 16 August 2002 (Tbilisi: Civil.ge). Available from: http://www.civil. ge/eng/article.php?id=2490 [Accessed 15 May 2019]

Balmaceda, M.M. (1998) "Gas, oil, and the linkages between domestic and foreign policies: The case of Ukraine", Europe-Asia Studies, 50 (2): 257-286

Balmaceda, M.M. (2008) Energy Dependency, Politics, and Corruption in the Former Soviet Union. Russia's Power, Oligarch' Profits and Ukraine's Missing Energy Policy, 1995-2006 (London/New York: Routledge) 
Bardin, V. (1992) "TsBR registriruet zarubezhnye scheta eksporterov nefti i gaza [The Central Bank registers oil and gas exporters' foreign accounts]" Kommersant, 25 May

Barsukov, Yu. (2017) "Nalog na dobychu dividendov [A tax on dividends extraction]" Kommersant, 13 June, p.1

Barsukov, Yu. (2018) "Dividendy poslednei nadezhdy [Dividends of the last resort]" Kommersant, 3 September, p.9

Bedevian, A. (2013) "New details of Russian-Armenian gas deal emerge" [online]. 17 December (Prague: Radio Free Europe/Radio Liberty). Available from: https:// www.azatutyun.am/a/25204160.html [Accessed 20 May 2019]

Belyakov, E. (2006) “'Gazprom’ pokoryaet Kazakhstan [Gazprom conquers Kazakhstan]" Gazeta, 26 October, p.13

Belyakov, E. (2008) "Energodiktat Moskvy i Astany stanovitsya yav'yu [The energy diktat of Moscow and Astana becomes reality]" Gazeta, 9 September, p. 9

Berger, M. and Proskurnina, O. (2008) Krest Chubaisa [Chubais's Cross] (Moscow: KoLibri)

Bilanenko, P. (2013) "Eto byl stroitel' imperii [He was an empire builder]" Kommersant, 12 February, p.7

Blagov, S. (2007) "Russia struggles to finalize Caspian gas pipeline deal with Turkmenistan" Eurasia Daily Monitor, 1 November

Bolukbasi, S. (1998) "The controversy over the Caspian Sea mineral resources: Conflicting perception, clashing interests”, Europe-Asia Studies, 50 (3): 397-414

BP (2012) BP Statistical Review of World Energy June 2012. London: BP. Available from: http://www.bp.com/statisticalreview [Accessed 14 June 2012]

Brauer, B. (2002) "Oil field hopes to become world power" The New York Times, 10 April, p.W001

Bruce, C. (2007) "Power resources. The political agenda in Russo-Moldovan gas relations", Problems of Post-Communism, 54 (3): 29-47

Bruce, C. and Yafimava, K. (2009) "Moldova's gas sector" in Pirani, S. ed., Russian and CIS Gas Markets and their Impact on Europe (Oxford: Oxford University Press for the Oxford Institute for Energy Studies) pp.170-202

Bugriy, M. (2013) “Kyiv testing 'pause' in EU integration” Eurasia Daily Monitor, 14 November

Butrin, D. (2001) "Nasledstvo Rema Vyakhireva [Rem Vyakhirev's heritage]" Kommersant-Den'gi, 6 June, p.12

Butrin, D. (2003a) “'Gazprom' sproektiruet gazoprovod iz Turkmenii, chtoby ego ne stroit' [Gazprom will plan a pipeline from Turkmenistan in order not to build it]" Kommersant, 25 July, p.6

Butrin, D. (2003b) “Gazprom' stal importerom [Gazprom became an importer]” Kommersant, 11 April, p.13

Butrin, D. (2005) "Orenburgskii GPZ stanet napolovinu kazakhskim [Orenburg Gas Processing Plant becomes half-Kazakh]” Kommersant, 10 March, p.13

Calus, K. (2015) “A Moldovan Yerevan” Transitions Online, 22 July

Chazan, G. (2008) "Turkmenistan gas field is one of world's largest" The Wall Street Journal, 16 October 2008, p.A9

Civil.ge (2003a) "President makes new appointments as Energy Minister resigns" [online]. 13 August (Tbilisi: Civil.ge). Available from: https://civil.ge/archives/103878 [Accessed 15 May 2019] 
Civil.ge (2003b) “GazProm, Georgia agree on strategic cooperation” [online]. 24 July (Tbilisi: Civil.ge). Available from: https://civil.ge/archives/103766 [Accessed 15 May 2019]

Civil.ge (2006) “Tbilisi receives Russian Gas via Azerbaijan” [online]. 23 January (Tbilisi: Civil.ge). Available from: https://civil.ge/archives/109637 [Accessed 15 May 2019]

Civil.ge (2017) "President, political parties, CSOs slam new transit deal with Gazprom" [online]. 17 January (Tbilisi: Civil.ge). Available from: https://civil.ge/a rchives/126087 [Accessed 21 May 2019]

Crawford, D. and White, G.L. (2005) "Dresdner official to get post with Baltic pipeline" The Wall Street Journal, 9 December

Daly, J.C.K. (2008) "Washington and Moscow vie for Turkmenistan's supplies" Eurasia Daily Monitor, 6 June

Danielyan, E. (2005a) "Putin visit highlights Russian interest in Armenia" Eurasia Daily Monitor, 29 March

Danielyan, E. (2005b) "Surge in Russian gas prices raises eyebrows in Armenia" Eurasia Daily Monitor, 7 December

Danielyan, E. (2005c) "Russian takeover of Armenian power grid prompts concern" Eurasia Daily Monitor, 21 July

Danielyan, E. (2007) "Soaring trade boosts Russian-Armenian economic ties" Eurasia Daily Monitor, 30 October

Decree No. 426 (28/04/1997) Ob osnovnykh polozheniyakh strukturnoi reformy $v$ sferakh estestvennykh monopolii [On the basic provisions for structural reform in the spheres of the natural monopolies] (Moscow: President of the Russian Federation)

Decree No. 478 (12/05/1997) O merakh po obospecheniyu gosudarstvennogo upravleniya zakreplennymi v federal'noi sobstvennosti aktsiyami Rossiiskogo aktsionernogo obschestva "Gazprom" [On measures to provide for state management of the shares of the Russian shareholding company "Gazprom" held in federal ownership] (Moscow: President of the Russian Federation)

Decree No. 529 (28/05/1997) O poryadke obrashcheniya aktsii Rossiiskogo aktsionernogo obshchestva "Gazprom" na period zakrepleniya v federal'noi sobstvennosti aktsii Rossiiskogo aktsionernogo obschestva "Gazprom" [On the order of circulation of the shares of the Russian shareholding company "Gazprom" in the period of federal ownership of the shares of the Russian shareholding company "Gazprom"] (Moscow: President of the Russian Federation)

Decree No. 538 (01/06/1992) Ob obespechenii deyatel'nosti Edinoi sistemy gazosnabzheniya strany [On securing the operation of the country's United system of gas supply] (Moscow: President of the Russian Federation)

Decree No. 599 (22/04/1996) O prodlenii sroka deistviya dogovora o doveritel'nom upravlenii zakreplennymi v federal'noi sobstvennosti aktsiyami mezhdu Pravitel'stvom Rossiiskoi Federatsii i Rossiiskim aktsionernom obshchestvom "Gazprom" [On prolongation of the agreement between the Government of the Russian Federation and the Russian shareholding company "Gazprom" on trustee management of shares held as federal property] (Moscow: President of the Russian Federation)

Decree No. 887 (25/07/1998) O realizatsii aktsii Rossiiskogo aktsionernogo obshchestva "Gazprom" [On realisation of the shares in the Russian shareholding company "Gazprom"] (Moscow: The President of the Russian Federation)

Decree No. 1285 (11/09/2012) O merakh po zashchite interesov Rossiiskoi Federatsii pri osushchestvlenii rossiiskimi yuridicheskimi litsami vneshneekonomicheskoi deyatel'nosti 
[On measures to protect the interests of the Russian Federation when foreign economic activity is carried out by a Russian juridical person] (Moscow: President of the Russian Federation)

Decree No. 1333 (05/11/1992) O preobrazovanii gosudarstvennogo gazovogo kontserna "Gazprom" v rossiiskoe aktsionernoe obshchestvo "Gazprom" [On the reorganisation of the state gas concern "Gazprom" into the Russian shareholding company "Gazprom"] (Moscow: President of the Russian Federation)

Decree No. 1333 (12/05/1997) O preobrazovanii gosudarstvennogo gazovogo kontserna "Gazprom" v rossiiskoe aktsionernoe obshchestvo "Gazprom" [On the reorganisation of the state gas concern "Gazprom" into the Russian shareholding company "Gazprom"] (Moscow: President of the Russian Federation)

Decree No. 2213 (26/12/1994) Ob uporyadochenii eksporta prirodnogo gaza [On the effectuation of natural gas export] (Moscow: The President of the Russian Federation)

Decree No. 2296 (24/12/1993) O doveritel'noi sobstvennosti (traste) [On entrusted property (trust)] (Moscow: The President of the Russian Federation)

Dubnov, V. (2003) "Rossiya - Turkmeniya. Istoriya darenogo konya, ili Gaz v obmen na ekstraditsiyu [Russia - Turkmenistan. The story of the gifted horse, or Gas in return for extradition]" Novoe vremya, 20 April, p.32

Embassy Ashgabat (2009) Turkmenistan: Gazprom and Turkmen government blame each other for April 9 pipeline explosion, 09ASHGABAT462/Wikileaks \#201845. Issue date 10 April 2009. Cablegate [online]. (Published by Wikileaks 1 September 2011). Available from: https://wikileaks.org/plusd/cables/09ASHGABAT462_a.html [Accessed 15 May 2019]

Embassy Moscow (2007) Russian corporate statism: Watch this space, 07MOSCOW1442/Wikileaks \#102758. Issue date 2 April 2007. Cablegate [online]. (Published by Wikileaks 8 September 2011). Available from: https://wikileaks.org/p lusd/cables/07MOSCOW1442_a.html [Accessed 15 May 2019]

Embassy Tashkent (2008) Uzbekistan: Gulnora Karimova's Geneva UN appointment may reflect concerns about the future, 08TASHKENT1072/Wikileaks \#170357. Issue date 18 September 2008. Cablegate [online]. (Published by Wikileaks 8 September 2011). Available from: https://wikileaks.org/plusd/cables/08TASHKENT1072_a.html [Accessed 15 May 2019]

Embassy Tashkent (2010) Uzbekistan: From A To Zeromax, 10TASHKENT27/Wikileaks \#244365. Issue date 20 January 2010. Cablegate [online]. (Published by Wikileaks 8 September 2011). Available from: https://wikileaks.org/plusd/cables/ 10TASHKENT27_a.html [Accessed 15 May 2019]

Embassy Yerevan (2005) Armenia looking to Iran to reduce dependence on Russian energy resources, 05YEREVAN2005391_a. Issue date 4 March 2005. Cablegate [online]. (Published by Wikileaks 30 August 2011). Available from: https://wikileaks. org/plusd/cables/05YEREVAN391_a.html [Accessed 21 May 2019]

Emel'yanov, S. (2003) "Eksport rossiiskogo gaza: istoriya, sostoyanie, perspektivy [Export of Russian gas: history, position, perspectives]" Neftegazovaya vertikal', No. 6

Ericson, R.E. (2012) "Eurasian natural gas: Significance and recent developments", Eurasian Geography and Economics, 53 (5): 615-648

Federal Law No. 117 (18/07/2006) Ob eksporte gaza [On the export of gas] (Moscow: The Federal Assembly)

Federal Tax Service (2007) Otchet po forme No.1-NM za 2006 g., svodnyi v tselom po Rossiiskoi Federatsii [Account for form No.1-NM for 2006, summarised for the 
Russian Federation]. 1nm2006.xls. Moscow: Federal'naya nalogovaya sluzhba. Available from: https://www.nalog.ru/rn77/related_activities/statistics_and_analytics/ forms/3832158/ [Accessed 13 June 2019]

Federal Tax Service (2008) Otchet po forme No.1-NM za 2007 g., svodnyi v tselom po Rossiiskoi Federatsii [Account for form No.1-NM for 2007, summarised for the Russian Federation]. 1nm2007.xls. Moscow: Federal'naya nalogovaya sluzhba. Available from: https://www.nalog.ru/rn77/related_activities/statistics_and_analytics/ forms/3832160/ [Accessed 13 June 2019]

Federal Tax Service (2009) Otchet po forme No.1-NM za 2008 g., svodnyi v tselom po Rossiiskoi Federatsii [Account for form No.1-NM for 2008, summarised for the Russian Federation]. 1nm2008.xls. Moscow: Federal'naya nalogovaya sluzhba. Available from: https://www.nalog.ru/rn77/related_activities/statistics_and_analytics/ forms/3832163/ [Accessed 13 June 2019]

Federal Tax Service (2010) Otchet po forme No.1-NM za 2009 g., svodnyi v tselom po Rossiiskoi Federatsii [Account for form No.1-NM for 2009, summarised for the Russian Federation]. 1nm2009.xls. Moscow: Federal'naya nalogovaya sluzhba. Available from: https://www.nalog.ru/rn77/related_activities/statistics_and_analytics/ forms/3827841/ [Accessed 13 June 2019]

Federal Tax Service (2011) Otchet po forme No.1-NM za 2010 g., svodnyi v tselom po Rossiiskoi Federatsii [Account for form No.1-NM for 2010, summarised for the Russian Federation]. 1_nm_svod070411.xls. Moscow: Federal'naya nalogovaya sluzhba. Available from: https://www.nalog.ru/rn77/related_activities/statistics_a nd_analytics/forms/3827842/ [Accessed 13 June 2019]

Federal Tax Service (2012) Otchet po forme No.1-NM za 2011 g., svodnyi v tselom po Rossiiskoi Federatsii [Account for form No.1-NM for 2011, summarised for the Russian Federation]. svod030412.xls. Moscow: Federal'naya nalogovaya sluzhba. Available from: https://www.nalog.ru/rn77/related_activities/statistics_and_analytics/ forms/3800184/ [Accessed 13 June 2019]

Federal Tax Service (2015) Otchet po forme No.1-NM za 2014 g., svodnyi v tselom po Rossiiskoi Federatsii [Account for form No.1-NM for 2014, summarised for the Russian Federation]. 1nm010115.xls. Moscow: Federal'naya nalogovaya sluzhba. Available from: https://www.nalog.ru/rn77/related_activities/statistics_and_analytics/ forms/4621635/ [Accessed 13 June 2019]

Federal Tax Service (2016) Otchet po forme No.1-NM za 2015 g., svodnyi v tselom po Rossiiskoi Federatsii [Account for form No.1-NM for 2015, summarised for the Russian Federation]. 1nm010116.xls. Moscow: Federal'naya nalogovaya sluzhba. Available from: https://www.nalog.ru/rn77/related_activities/statistics_and_analytics/ forms/5432274/ [Accessed 13 June 2019]

Federal Tax Service (2017) Otchet po forme No.1-NM za 2016 g., svodnyi v tselom po Rossiiskoi Federatsii [Account for form No.1-NM for 2016, summarised for the Russian Federation]. 1nm010117.xls. Moscow: Federal'naya nalogovaya sluzhba. Available from: https://www.nalog.ru/rn77/related_activities/statistics_and_analytics/ forms/6040192/ [Accessed 13 June 2019]

Federal Tax Service (2018) Otchet po forme No.1-NM za 2017 g., svodnyi v tselom po Rossiiskoi Federatsii [Account for form No.1-NM for 2017, summarised for the Russian Federation]. 1nm010118.xls. Moscow: Federal'naya nalogovaya sluzhba. Available from: https://www.nalog.ru/rn77/related_activities/statistics_and_analytics/ forms/6772396/ [Accessed 13 June 2019] 
Fedorova, T. and Kulikov, S. (2007) 'Pensii za Tiraspol' zaplatit 'Gazprom' [Gazprom will pay Tiraspol's pensions]" Nezavisimaya gazeta, 13 July, p.1

Finon, D. and Locatelli, C. (2008) "Russian and European gas interdependence: Could contractual trade channel geopolitics?", Energy Policy, 36 (1): 423-442

Flink, A. (2002) "Kazakhskii gaz pustyat v rossiiskuyu trubu [Kazakh gas allowed into Russian pipe]" Kommersant, 6 December, p.14

Franza, L. (2015) From South Stream to Turk Stream. CIEP Paper. 05 (Clingendael: Clingendael International Energy Programme)

Gabuev, A. (2016) Friends with Benefits? Russian-Chinese Relations after the Ukraine Crisis (Moscow: Carnegie Moscow Center)

Gabuev, A. and Granik, I. (2009) "Iran i Rossiya sovpali v Kaspiiskom more [Iran and Russia agree in the Caspian Sea]" Kommersant, 18 August, p.5

Gabuev, A. et al. (2010) "Dmitrii Medvedev ogranichil Azerbaidzhan [Dmitrii Medvedev limits Azerbaijan]" Kommersant, 4 September, p.1

Gamova, S. (2012) 'Kreml' stryakhivaet pyl' s 'plana Kozaka' [Kremlin dusts off the Kozak plan]" Nezavisimaya gazeta, 12 September, p.1

Gaulier, G. and Zignago, S. (2010) BACI: International Trade Database at the Product-level. The 1994-2007 Version. CEPII Working Paper. (Paris: CEPII)

Gavshina, O. (2007) "Dorogie sosedi [Dear neighbours]" Gazeta, 11 May, p.13

Gazprom (2003) Gazprom. Godovoi otchet 2002 [Gazprom. Annual report 2002] (Moscow: Gazprom)

Gazprom (2004a) Gazprom. Godovoi otchet 2003 [Gazprom. Annual report 2003] (Moscow: Gazprom)

Gazprom (2004b) "Na puti k energeticheskoi kompanii - tezisi doklada Predsedatelya Pravleniya "OAO Gazprom" Alekseya Millera [On the way to an energy company theses from a presentation by Gazprom's management chairman, Aleksei Miller]" [online]. 25 June (Moscow: Gazprom). Available from: http://www.gazprom.ru/p ress/news/2004/june/article54896/ [Accessed 15 May 2019]

Gazprom (2005) Gazprom. Godovoi otchet 2004 [Gazprom. Annual report 2004] (Moscow: Gazprom)

Gazprom (2006) “Ob itogakh vizita delegatsii OAO 'Gazprom' v Uzbekistan [Results of Gazprom delegation's visit to Uzbkistan]” [online]. 17 May (Moscow: Gazprom). Available from: http://www.gazprom.ru/press/news/2006/may/article55734/ [Accessed 15 May 2019]

Gazprom (2007) Gazprom. Godovoi otchet 2006 [Gazprom. Annual report 2006] (Moscow: Gazprom)

Gazprom (2008) Gazprom v tsifrakh 2004-2008 gg. Spravochnik [Gazprom in numbers 2004-2008. A handbook] (Moscow: Gazprom)

Gazprom (2009) Gazprom. Godovoi otchet 2008 [Gazprom. Annual report 2008] (Moscow: Gazprom)

Gazprom (2012a) "Srednyaya Aziya - Tsentr [Central Asia-Centre]" [online]. n.d. (Moscow: Gazprom). Available from: http://www.gazprom.ru/about/production/p rojects/pipelines/central-asia/ [Accessed 4 July 2012]

Gazprom (2012b) Rasshiryaya gorizonty. Godovoi otchet 2011 [Broadening horizons. Annual report 2011] (Moscow: Gazprom)

Gazprom (2013a) "Gazprom na rossiiskom rynke [Gazprom on the Russian market]" [online]. n.d. (Moscow: Gazprom). Available from: http://www.gazpromquestions. ru/russian-market/ [Accessed 19 June 2013] 
Gazprom (2013b) “'Gazprom' planiruet uvelichit' dolyu v 'ArmRosgazprome' do $100 \%$ [Gazprom plans to increase share in ArmRosgazprom to 100\%]" [online]. 17 June (Moscow: Gazprom). Available from: http://www.gazprom.ru/press/news/2013/ june/article164593/ [Accessed 15 May 2019]

Gazprom (2019a) "Gazifikatsiya [Gasification]" [online]. (Moscow: Gazprom). Available from: http://www.gazprom.ru/about/production/gasification/ [Accessed 30 May 2019]

Gazprom (2019b) "Gas and oil production" [online]. (Moscow: Gazprom). Available from: http://www.gazprom.com/about/production/extraction/ [Accessed 1 June 2019]

Gazprom (2019c) "Marketing" [online]. (Moscow: Gazprom). Available from: http:// www.gazprom.com/about/marketing/ [Accessed 1 June 2019]

Gazprom (2019d) "Podzemnoe khranenie gaza [Underground storage of gas]" [online]. (Moscow: Gazprom). Available from: http://www.gazprom.ru/about/production/ underground-storage/ [Accessed 30 May 2019]

Golub, K. (2012) "Ot Ungen do Yass gazoprovodom podat' [Ungheni is just a gas pipeline from Iasi]" Kommersant Moldova, 14 March 2012

Gray, D. (1995) Reforming the Energy Sector in Transition Economies. World Bank Discussion Papers. 296 (Washington, DC: The World Bank)

Grib, N. and Gavrish, O. (2009) "Predlozhenie, ot kotorogo nel'zya ne uzhat'sya [An offer you cannot but shrink away from]" Kommersant, 2 June, p.1

Grigor'eva, E. (2005) "Putin - Yushchenko: Gazovyi torg neumesten [Putin-Yushchenko: Gas bargaining inappropriate]" Izvestiya, 9 December, p.1

Grigoryan, A. (2013) "Armenia chooses Customs Union over EU Association Agreement" CACI Analyst, 18 September

Grivach, A. (2005) 'Sosedi. Syurpriz 'Gazpromu' [Neighbours. A surprise for Gazprom]" Vremya novostei, 4 October, p.8

Grivach, A. (2009) "Ob'yasnenie vzryva [An explanation for the explosion]" Vremya novostei, 2 June, p. 8

Grivach, A. (2010) "Vostochnaya khitrost' [Eastern cunning]" Vremya novostei, 20 July, p.7

Gularidze, T. (2003a) "Government Posed to Yield to the US Pressure on GazProm Deal" [online]. 9 June (Tbilisi: Civil.ge). Available from: http://www.civil.ge/eng/a rticle.php?id=4354 [Accessed 15 May 2019]

Gularidze, T. (2003b) "Georgia's pending GazProm deal stirs political controversy" [online]. 30 May (Tbilisi: Civil.ge). Available from: http://www.civil.ge/eng/article. php?id=4296 [Accessed 15 May 2019]

Gurbanov, I. (2018) "Southern gas corridor raises significant financing, but still faces provocations" Eurasia Daily Monitor, 3 April

Gustafson, T. (2012) Wheel of Fortune. The Battle for Oil and Power in Russia (Cambridge, MA/London: The Belknap Press of Harvard University Press)

Henderson, J. (2015) "Competition for customers in the evolving Russian gas market", Europe-Asia Studies, 67 (3): 345-369

Henderson, J. et al. (2018) "The SPIMEX gas exchange: Russian gas trading possibilities", Oxford Energy Paper [online] NG 126 Available from https://www.oxforde nergy.org/wpcms/wp-content/uploads/2018/01/The-SPIMEX-Gas-Exchange-RussianGas-Trading-Possibilities-NG-126.pdf [Accessed 1 June 2019]

Hill, F. (2004) Energy Empire: Oil, Gas, and Russia's Revival (London: The Foreign Policy Centre) 
IAA Trend (2006) "Prirodnyi gaz v Gruziyu budet postavlyat' kompaniya 'KazRosGaz' [KazRosGaz will supply natural gas to Georgia]" IAA Trend, 22 May

IEA (2015) Online Data Services, Issue date [online]. (Published by International Energy Agency 2015). Available from: http://www.iea.org/statistics/ [Accessed 6 October 2015]

Infotag (2012) "'Esli Moldova i Pridnestrov'e - obshchee gosudarstvo, to i gazovyi schet dolzhen byt' obshchim' - Dmitrii Rogozin [Dmitrii Rogozin: 'If Moldova and Transnistria are a common state, then the gas bill, too, should be common']" [online]. 19 November (Chisinau: Information Agency Infotag). Available from: http://www. infotag.md/news/598422/ [Accessed 15 May 2019]

Ioffe, G. (2011) "Washington struggles to formulate strategy on Belarus" Eurasia Daily Monitor, 12 December

Ismayilov, R. (2007) "Rich country, poor people" Transitions Online, 17 January

Ivanov, N. (1997) “Gazpromu mozhno tol'ko verit' [In Gazprom one can only believe]" Segodnya, 16 May

Jack, A. (2001a) "Link between Gazprom and Itera found", Financial Times, 14 March, p.33

Jack, A. (2001b) "Gazprom auditors to probe links with Itera", Financial Times, 15 March, p.29

Jack, A. (2001c), "Auditors find no evidence of deals that aided Itera", Financial Times, 6 July, p.22

Kardaś, S. (2018) Neither Super-rich, nor Bankrupt. Gazprom's Financial Condition. OSW Studies. 79 (Warsaw: OSW Centre for Eastern Studies/Osrodek Studiow Wschodnich)

Kardaś, S. and Iwański, T. (2018) "From vassalisation to emancipation. UkrainianRussian gas cooperation has been revised" OSW Commentary, 7 March

KazRosGaz (2012) "KazRosGaz": soyuz Rossii i Kazakhstana [KazRosGaz: a union between Russia and Kazakhstan]. Promotional material, KazRosGaz

Kirichenko, N. and Solov'ev, M. (1992) "Dom, kotoryi postroil Viktor [The house that Viktor built]" Kommersant, 21 December

Konończuk, W., Matuszak, S. and Paszyc, E. (2012) "Russian-Turkish agreement on the South Stream pipeline - an instrument of pressure on Ukraine" OSW Analysis, 4 January

Konończuk, W., Kardaś, S. and Łoskot-Strachota, A. (2014) "Success? The Russia/ Ukraine/EU gas agreement" OSW Analysis, 5 November

Krashakov, A. (2006) "Erevan obmenyal trubu na gaz [Yerevan exchanged a pipeline for gas]" Nezavisimaya gazeta, 7 April, p.3

Krasnaya Zvezda (1992) "Pravitel'stvo Rossii izyskivaet sredstva dlya finansirovaniya rossiiskikh voisk $\mathrm{v}$ stranakh Baltii [The Russian government seeks out funds to finance the Russian forces in the Baltic states]" Krasnaya Zvezda, 12 November

Kravets, V. (1997) "Ni shagu nazad [Not a step back]" Neft' $i$ Kapital, September

Kravets, V. (1998) "Do polnoi 'otklyuchki' [Up to full disconnection]" Neft' i Kapital, August

Krym.Realii (2019) "Rossiya ne priznaet reshenie suda v Gaage po isku 'Naftogaza' ob aktivakh v Krymu [Russia does not acknowledge the Hague Court's decision on Naftogaz's suit for Crimea assets]" [online]. 1 March (Prague: Radio Free Europe/Radio Liberty). Available from: https://ru.krymr.com/a/news-rossiya-ne-priznaet-reshenia -suda-v-gaage-po-aktivam-v-krymu/29798688.html [Accessed 24 May 2019] 
Kryukov, V. and Moe, A. (1996) The New Russian Corporatism? A Case Study of Gazprom. The Post-Soviet Business Forum (London: The Royal Institute of International Affairs)

Levin, K. (2000) "Vyakhireva rezhut popolam [Vyakhirev will be cut in two]" Kommersant-Den'gi, 2 February, p. 15

Logvinenko, E. (2001) “'Goluboi potok' s nebes - na zemlyu [Blue Stream: from the heavens down to earth]" Neft' $i$ Kapital, April

Łoskot-Strachota, A., Konończuk, W. and Kardaś, S. (2014) "Gas negotiations Ukraine-Russia-EU: War of attrition" OSW Analysis, 8 October

Lukin, O. (2010) "Im ne zhit' drug bez druga? [Can they not live without each other?]" Neftegazovaya vertikal', No. 6, pp.64-66

Lukin, O. (2011) "Podklyuchili Kaspii [The Caspian is connected]" Neftegazovaya vertikal', No. 18 , pp.84-87

Lukin, O. (2012) “Tsentral'naya Aziya: Usilenie gazovoi konkurentsii [Central Asia: The gas competition strengthens]" Neftegazovaya vertikal', No. 9, pp.18-20

Lyashenko, G. (2003) "Byudzhetnye den'gi tekut potokom [Budget money runs in a stream]" Kommersant, 18 January, p.5

Makarkin, A. (2009) "Kaspiiskoe protivostoyanie [Caspian confrontation]" Neft' $i$ Kapital, October

Makarkin, A. (2013) "Dva predsedatelya [Two chairmen]" Neft' i Kapital, JanuaryFebruary

Malkova, I. and Igumenov, V. (2012) "Poslednee interv'yu Rema Vyakhireva: 'Putin kogda uslyshal, chto ya ukhozhu, tak obradovalsya' [Rem Vyakhirev's final interview: 'When he heard that I was leaving, Putin was so happy']" Forbes, September

Markus, U. (1995) "Belarus: Heading off an energy disaster" Transition, 14 April

Markus, U. (1996) "Energy: Ukraine and Belarus seek help abroad" Transition, 3 May

Meshcherin, A. (2014a) "Pir v preddverii chumy? [A feast on the eve of plague?]" Neftegazovaya vertikal', No. 13-14, pp.74-81

Meshcherin, A. (2014b) "Ne bylo by schast'ya... [There would be no happiness...]" Neftegazovaya vertikal', No. 11, pp.36-45

Milov, V. (2011) "Ups and downs of the Russia-Turkmenistan relationship" in Dellecker, A. and Gomart, T. ed., Russian Energy Security and Foreign Policy (London/New York: Routledge) pp.89-106

Ministry of Energy (2009) Energeticheskaya strategiya Rossii na period do 2030 goda [Russia's Energy Strategy for the period to 2030] (Moscow: Institute of Energy Strategy)

Ministry of Industry and Trade (2003) Energeticheskaya strategiya Rossii na period do 2020 goda [Russia's Energy Strategy for the period to 2020) (Moscow: Ministerstvo promyshlennosti i torgovli)

Mite, V. (2003) "Russia: Gazprom May Abandon Cooperation Deals with Belarus, Leaving Minsk in Economic Lurch" [online]. 10 September (Prague: Radio Free Europe/Radio Liberty). Available from: http://www.rferl.org/content/article/ 1104305.html [Accessed 15 May 2019]

Mitrova, T. (2009) "Natural gas in transitions: systemic reform issues" in Pirani, S. ed., Russian and CIS Gas Markets and their Impact on Europe (Oxford: Oxford University Press) pp.13-53

Mitrova, T., Pirani, S. and Stern, J.P. (2009) "Russia, the CIS and Europe: Gas trade and transit" in Pirani, S. ed., Russian and CIS Gas Markets and their Impact on Europe (Oxford: Oxford University Press) pp.395-441 
Molnar, S. (2012) "Romanian Government approves gas pipeline between Romania and Moldova" Natural Gas Europe, 6 June

Monaghan, A. (2012) "The vertikal: power and authority in Russia", International Affairs, 88 (1): 1-16

Mordyushenko, O., Rozhdestvenskaya, Ya. and Solov'ev, V. (2012) "Ukaz prezidenta Rossii nashel pervogo potrebitelya [The president of Russia's decree found its first user]" Kommersant, 13 September, p.6

Moshes, A. (2012) "Za retseptom dolgoletiya [For the recipe of a long life]" Ezhednevnyi zhurnal, 30 May

Muradova, M. and Abbasov, R. (2006) "Heat from the South" Transitions Online, 9 January

Naftogaz Ukrainy (2015) Richnyi zvit 2014 [Annual report 2014]. (Kyiv: Naftogaz Ukrainy)

Naftogaz Ukrainy (2016) "Naftogaz files arbitration against Russia to recover \$2.6 billion for stolen Crimea assets" [online]. 19 October (Kyiv: Naftogaz Ukrainy). Available from: http://www.naftogaz.com/www/3/nakweben.nsf/0/DC8AA6A56E589FE3C2258 05100278490 [Accessed 24 May 2019]

Naftogaz Ukrainy (2018) "Win for Naftogaz in the gas transit arbitration with Gazprom. Gazprom to pay USD 2.56 billion to Naftogaz" [online]. 28 February (Kyiv: Naftogaz Ukrainy). Available from: http://www.naftogaz.com/www/3/nakweben.nsf/ 0/4927C1CECCAC4969C22582420076095F [Accessed 13 June 2019]

Naftogaz Ukrainy (2019) "Types of activities" [online]. (Kyiv: Naftogaz Ukrainy). Available from: http://www.naftogaz.com/www/3/nakweben.nsf/0/74B2346ABA0CB C69C22570D80031A365 [Accessed 24 May 2019]

Neft' $i$ Kapital (2003a) "Gordiev uzel protivorechii [A Gordian knot of contradictions]" Neft' i Kapital, May

Neft' $i$ Kapital (2003b) "Est' takoe slovo l'goty [There is a word called privilege]" Neft' i Kapital, March

Neft' i Kapital (2003c) "Lider menyaetsya [The leader is changing]" Neft' $i$ Kapital, February

Neft' i Kapital (2003d) “Turkmenskie perspektivy 'Gazproma' [Gazprom's Turkmen perspectives]" Neft' $i$ Kapital, May

Neft' $i$ Kapital (2004) "Rem Vyakhirev" Neft' i Kapital, October

Neft' $i$ Kapital (2005a) "Torg umesten [Bargaining is appropriate]" Neft' $i$ Kapital, May

Neft' $i$ Kapital (2005b) 'Geopoliticheskoe ruslo 'Golubogo potoka' [Blue Stream's geopolitical turn]" Neft' $i$ Kapital, December

Neft' i Kapital (2005c) "Iranskii gaz mozhet pomoch' Rossii [Iranian gas can help Russia]" Neft' i Kapital, May

Neft' $i$ Kapital (2006a) "Proyasnyayutsya perspektivy [The perspectives are becoming clear]" Neft' $i$ Kapital, September

Neft' $i$ Kapital (2006b) "Bakinskii gazovyi uzel [The Baku gas junction]" Neft' $i$ Kapital, May

Neft' $i$ Kapital (2006c) "Nikto i ne somneval'sya [As nobody even doubted]" Neft' $i$ Kapital, July

Neft' $i$ Kapital (2006d) "Gazovyi debyut [A gas debut]" Neft' $i$ Kapital, October

Neft' i Kapital (2007) "No transit!” Neft' i Kapital, May

Neft' i Kapital (2008a) "God gazovoi nezavisimosti [The year of gas independence]" Neft' i Kapital, November

Neft' i Kapital (2008b) “Turkmenskii gaz [Turkmen gas]” Neft' i Kapital, August 
Neft' $i$ Kapital (2009a) "Put' svoboden [The road is open]" Neft' $i$ Kapital, November

Neft' $i$ Kapital (2009b) "Bol'she, chem kazhetsya [More than meets the eye]" Neft' $i$ Kapital, April

Neft' $i$ Kapital (2010a) “Transaziatskii ekspress [Trans-Asian express]" Neft' i Kapital, October

Neft' $i$ Kapital (2010b) "Shel'f za trubu [The shelf for a pipe]" Neft' $i$ Kapital, October

Neft' $i$ Kapital (2010c) "Igra na gazovoi trube [The gas pipeline game]" Neft' $i$ Kapital, September

Neft' i Kapital (2011a) "Svoi chelovek v 'Gazprome' [A man at home in Gazprom]" Neft' i Kapital, July

Neft' i Kapital (2011b) “'Gazprom' i Moldova rassmotreli voprosy zaklyucheniya novogo kontrakta [Gazprom and Moldova consider questions related to the conclusion of a new contract]" [online]. 3 November (Moscow: IG Industriya). Available from: https:// oilcapital.ru/news/export/03-11-2011/gazprom-i-moldova-rassmotreli-voprosy-zaklyuc heniya-novogo-kontrakta [Accessed 15 May 2019]

Neft' $i$ Kapital (2011c) "Polimery bez polumer [Polymers without half measures]" Neft' i Kapital, October

Neft' $i$ Kapital (2012a) "Rossiya trebuet ot Moldavii otkazat'sya ot Tret'ego energopaketa EC vzamen na skidku na gaz [Russia demands that Moldova retracts from the EU's Third Energy Package in return for a gas discount]" [online]. 13 September (Moscow: IG Industriya). Available from: https://oilcapital.ru/news/export/ 13-09-2012/rossiya-trebuet-ot-moldavii-otkazatsya-ot-tretiego-energopaketa-es-vzam en-na-skidku-na-gaz [Accessed 15 May 2019]

Neft' $i$ Kapital (2012b) "Moldaviya poprosit ES otlozhit' vnedrenie tret'ego energopaketa do $2020 \mathrm{~g}$. [Moldova will ask the EU to delay implementation of the Third Energy Package to 2020]" [online]. 1 October (Moscow: IG Industriya). Available from: https://oilcapital. ru/news/export/01-10-2012/moldaviya-poprosit-es-otlozhit-vnedrenie-tretiego-energopa keta-do-2020-g [Accessed 15 May 2019]

Neft' $i$ Kapital (2013a) 'Po-prezhnemu nedootsenen [Undervalued as always]" Neft' $i$ Kapital, January-February

Neft' $i$ Kapital (2013b) “Gaz Rossii v Rossii [Russia’s gas in Russia]” Neft' i Kapital, January-February

Neft' i Kapital (2013c) "Chto khorosho dlya Gazproma... [What is good for Gazprom...]" Neft' $i$ Kapital, January-February

Neft' $i$ Kapital (2013d) "Razvitie nezavisimykh [The development of the independents]" Neft' i Kapital, January-February

Neft' $i$ Kapital (2013e) "Strukturnaya evolyutsiya neftegazovoi otrasli [The structural evolution of the oil and gas industry]" Neft' $i$ Kapital, May

Neftegazovaya vertikal' (2003) "Vklad v delo razvitiya eksporta gaza [A contribution to the cause of gas export development]" Neftegazovaya vertikal', No. 6

Neftegazovaya vertikal' (2011) "Karachaganak Petroleum Operating B.V." Neftegazovaya vertikal', No. 18, pp.42-43

Neftegazovaya vertikal' (2015) "Gazovye golovolomki [Gas puzzles]" Neftegazovaya vertikal', No. 3, pp.52-58

Neftegazovaya vertikal' (2017a) 'Mikhail Krutikhin: Sozdanie VINK - men'shee iz zol [Mikhail Krutikhin: The creation of the vertically integrated oil companies was the lesser evil]" Neftegazovaya vertikal', No. 21, pp.28-34

Neftegazovaya vertikal' (2017b) "Ne tol'ko megaproekty [Not just mega-projects]" Neftegazovaya vertikal', No. 9, pp.52-56 
Neftegazovaya vertikal' (2017c) "Uzbekskaya metamorfoza [Uzbek metamorphosis]" Neftegazovaya vertikal', No. 18, pp.80-84

Nikitin, D. and Evdokimova, A. (2014) "Ukraina bez skidok [Ukraine without discounts]" RBK Daily, 4 April, p.4

Nikolaev, I., Privalov, A. and Kalinichenko, N. (1994) "Privatizatsiya Gazproma [The privatisation of Gazprom]" Kommersant, 8 February

Oilcapital.ru (2012) "Reiting vliyaniya krupnykh predprinimatelei i top-menedzherov toplivno-energeticheskogo kompleksa $v$ dekabre $2012 \mathrm{~g}$. [Rating of the influence of major businessmen and top managers in the fuel and energy complex, December 2012]" [online]. 6 December (Moscow: IG Industriya). Available from: https://oilcapita 1.ru/news/companies/06-12-2012/reyting-vliyaniya-krupnyh-predprinimateley-i-top-me nedzherov-tek-v-dekabre-2012-g [Accessed 18 March 2019]

Oilcapital.ru (2016) "Reiting vliyaniya krupnykh predprinimatelei i top-menedzherov toplivno-energeticheskogo kompleksa v marte $2016 \mathrm{~g}$. [Rating of the influence of major businessmen and top managers in the fuel and energy complex, March 2016]" [online]. 29 March (Moscow: IG Industriya). Available from: https:/oilcapital.ru/ news/companies/29-03-2016/reyting-vliyaniya-krupnyh-predprinimateley-i-top-menedz herov-toplivno-energeticheskogo-kompleksa-v-marte-2016-g [Accessed 20 February 2019]

OMRI (1995) “OMRI Daily Digest” [online]. 16 May (Prague: Open Media Research Institute). Available from: http://www.rferl.org/content/article/1140936.html [Accessed 15 May 2019]

Panfilova, V. (2004) "Molchanie patriotov. Shest'desyat tysyach rossii'skikh grazhdan v Turkmenii poboyalis' prinyat' uchastie v vyborakh prezidenta [The silence of the patriots. Sixty thousand Russian citizens in Turkmenistan were afraid to participate in the presidential elections]" Nezavisimaya gazeta, 19 March, p.5

Panfilova, V. (2009) "Dushanbe pred"yavit Moskve schet [Dushanbe gives Russia the bill]" Nezavisimaya gazeta, 20 February, p.1

Pannier, B. (2017) "Iran rejects Turkmen proposal for gas shipments to Turkey" [online]. Posted to the blog 'Qishloq Ovozi' on 30 October. Available from: https:// www.rferl.org/a/iran-rejects-turkmenistan-proposal-gas-shipments-turkey/28824118. html [Accessed 22 May 2019]

Panyushkin, V. and Zygar', M. (2007) Gazprom. Novoe russkoe oruzhie [Gazprom. The new Russian weapon] (Moscow: Zakharov)

Parfenova, M. (2012) 'Schetnaya palata nedovol'na 'Gazpromom' [The Audit Chamber is dissatisfied with Gazprom]" Izvestiya, 19 April, p.5

Pirani, S. (2009a) "Ukraine: A gas dependent state" in Pirani, S. ed., Russian and CIS Gas Markets and their Impact on Europe (Oxford: Oxford University Press for the Oxford Institute for Energy Studies) pp.93-132

Pirani, S. (2009b) "Introduction. Political and economic factors in the Russian and CIS gas trade" in Pirani, S. ed., Russian and CIS Gas Markets and their Impact on Europe (Oxford: Oxford University Press for the Oxford Institute for Energy Studies) pp.1-12

Pirani, S. (2018a) "After the Gazprom-Naftogaz arbitration: Commerce still entangled in politics", Oxford Energy Insight [online] (31). Available from https://www. oxfordenergy.org/wpcms/wp-content/uploads/2018/03/After-the-Gazprom-Naftoga z-arbitration-commerce-still-entangled-with-politics-Insight-31.pdf [Accessed 24 May 2019] 
Pirani, S. (2018b) "Russian gas transit through Ukraine after 2019: the options", Oxford Institute for Energy Studies [online] Available from https://www.oxfordenergy.org/p ublications/russian-gas-transit-ukraine-2019-options/ [Accessed 23 May 2019]

Pirani, S., Stern, J.P. and Yafimava, K. (2010) The April 2010 Russo-Ukrainian Gas Agreement and its Implications for Europe (Oxford: The Oxford Institute for Energy Studies)

Podobedova, L. and Dzyadko, T. (2018) "Pribyl'nyi vsem podryad [Profitable for one after the other] (paper)/Pribyl' dlya podryadchikov: skol'ko aktsionery 'Gazproma' teryayut na stroikakh [Profits for subcontractors: how much Gazprom's shareholders lose on construction] (web)" RBK Daily, 21 May, pp.1, 10

Popov, I. (2007) "Staraya gvardiya [The old guard]" Forbes, April

Popşoi, M. (2016) "Are Moldovan consumers financing Transnistrian separatism?" Eurasia Daily Monitor, 21 April

Prokhorov, I. (2006) "A u nas - tbilisskii gaz! [But we have Tbilisi’s gas]" Kazakhstanskaya pravda, 23 May 2006

Prostakov, G. (2012) “Chernomorskie kozyri Ukrainy [Ukraine’s Black Sea trump cards]" Neftegazovaya vertikal', No. 10, pp.30-32

Rahimov, R. (2019) "Turkmenistan redirects its oil export flows from Azerbaijan to Russia” Eurasia Daily Monitor, 25 February

RBK (2018) "RBK 500: Reiting rossiiskogo biznesa [RBK 500: The Russian Business Rating]" [online]. (Moscow: Available from: https://www.rbc.ru/rbc500/ [Accessed 23 November 2018]

Reznik, I. (2002a) "Vyakhirev ukhodit v otstavku [Vyakhirev resigns]" Vedomosti, 29 January

Reznik, I. (2002b) "Usmanov pomog Milleru [Usmanov helps Miller]” Vedomosti, 26 December

Reznik, I. (2009) "Chistil'shchik Ryazanov [Ryazanov the cleaner]" Vedomosti, 23 March

Reznik, I. and Egorova, T. (2006a) “'Gazprom” vmesto RAO EES [Gazprom instead of RAO UES]” Vedomosti, 10 April

Reznik, I. and Egorova, T. (2006b) “'Gazprom' propisalsya v Armenii [Gazprom settles in Armenia]" Vedomosti, 7 April

RFE/RL (1998) "RFE/RL Newsline" Radio Free Europe/Radio Liberty, 31 July

RFE/RL (1999) "RFE/RL Iran Report" Radio Free Europe/Radio Liberty, 22 November

RFE/RL (2000) "RFE/RL Newsline" Radio Free Europe/Radio Liberty, 2 March

RFE/RL (2001a) "RFE/RL Newsline" Radio Free Europe/Radio Liberty, 13 March

RFE/RL (2001b) "RFE/RL Newsline" Radio Free Europe/Radio Liberty, 16 March

RFE/RL (2004) "RFE/RL Newsline" Radio Free Europe/Radio Liberty, 28 June

RFE/RL (2005) "RFE/RL Newsline" Radio Free Europe/Radio Liberty, 9 September

RFE/RL (2006) "RFE/RL Newsline" Radio Free Europe/Radio Liberty, 30 January

RFE/RL (2015) "Romania starts shipping gas to Moldova" [online]. 4 March (Prague: Radio Free Europe/Radio Liberty). Available from: https://www.rferl.org/a/romania -moldova-gas/26882225.html [Accessed 25 May 2019]

RIA Novosti (2015) "Medvedev podpisal postanovlenie o predostavlenii Ukraine skidki na gaz [Medvedev signs resolution on extending a gas discount to Ukraine]" [online]. 1 April (Moscow: RIA Novosti). Available from: https://ria.ru/20150401/1055883614. html [Accessed 24 May 2019]

Roberts, J. (2011) “After the war" in Dellecker, A. and Gomart, T. ed., Russian Energy Security and Foreign Policy (London/New York: Routledge) pp.170-187 
Rozhkova, M. and Reznik, I. (2013) "U nego bylo chut'e [He had a good nose]" Vedomosti, 12 February

Rukhadze, V. (2015) "Russia's Gazprom seems set to return to Georgia” Eurasia Daily Monitor, 21 October

Samokhvalov, V. (2015) "Ukraine between Russia and the European Union: Triangle revisited”, Europe-Asia Studies, 67 (9): 1371-1393

Sapozhkov, O. (2012) "Gosudarstvo zabiraet chetvertinu [The state will take one quarter]" Kommersant, 17 November, p.1

Savushkin, S. (2000) "Turkmeniskii gaz snova v rossiiskoi trube [Turkmen gas again fills Russia's pipelines]" Neft' i Kapital, February

Sergeev, V. and Grib, N. (2006) "Moldaviya gotova otdat' chuzhoe [Moldova ready to give away what isn't theirs]" Kommersant, 18 January, p.7

Sherr, J. (2013) Hard Diplomacy and Soft Coercion. Russia's Influence Abroad (London: Chatham House)

Silady, A., Tesema, M. and Frye, B. (2013) "The Eastern Partnership Summit: A cheat sheet" Transitions Online, 22 November

Simoes, A.J.G. and Hidalgo, C.A. (2011) "The Economic Complexity Observatory: An analytical tool for understanding the dynamics of economic development" in Workshops at the Twenty-Fifth AAAI Conference on Artificial Intelligence

Smirnov, G. (1997) "Gazovyi bumerang vozvrashchaetsya [The gas boomerang returns]" Neft' $i$ Kapital, July-August

Smith, H. (2012) "Russian foreign policy and energy: The case of the Nord Stream gas pipeline" in Aalto, P. ed., Russia's Energy Policies. National, Interregional and Global Levels (Cheltenham, UK/Northampton, USA: Edward Elgar) pp.117-135

Socor, V. (2006) "Russian energy supply cut off to Georgia: Another wake-up signal to the West" Eurasia Daily Monitor, 23 January

Socor, V. (2012) "Moldova's Filat discusses energy sector agreement with Russia's Putin and Medvedev" Eurasia Daily Monitor, 14 September

Sokolov, L. (2007) "KazRosGaz' - pyat' let na gazovom rynke [KazRosGaz: five years in the gas market]" Kazakhstanskaya pravda, 21 March

Stern, J.P. (1993) Oil and Gas in the Former Soviet Union. Post-Soviet Business Forum (London: Royal Institute of International Affairs)

Stern, J.P. (2005) The Future of Russian Gas and Gazprom (Oxford: Oxford University Press/Oxford Institute for Energy Studies)

Stern, J.P. (2009) "The Russian gas balance to 2015: Difficult years ahead" in Pirani, S. ed., Russian and CIS Gas Markets and their Impact on Europe (Oxford: Oxford University Press for the Oxford Institute for Energy Studies) pp.54-92

Tatevosyan, A. and Reutov, A. (2006) "Armeniyu ubedili oruzhiem [Armenia was convinced by weapons]" Kommersant, 24 March, p.9

Tatevosyan, A., Reutov, A. and Grib, N. (2006) "Soglashenie. Armeniya perekhodit na 'Gazprom' [Agreement. Armenia transfers to Gazprom]” Kommersant, 7 April, p.1

Ter-Grigoryan, A. (2006) "V Armenii schitayut, chto otnosheniya s Rossiei napravleny na ukreplenie politiki Kocharyan [In Armenia, relations with Russia are seen as directed towards strengthening Kocharyan's policy]" [online]. 13 November (Moscow: Kavkaz-Uzel). Available from: http://www.kavkaz-uzel.ru/articles/103489/ [Accessed 15 May 2019]

Tomiuc, E. (2003) "Moldova: Caught between a hammer and a sickle as anti-Communist protests continue" [online]. 28 November (Prague: Radio Free Europe/Radio 
Liberty). Available from: http://www.rferl.org/content/article/1105158.html [Accessed 15 May 2019]

Tomiuc, E. and Krushelnycky, A. (2003) "Moldova: Putin cancels trip to Chisinau as Moldovan, Transdniestrian leaders prepare to sign memorandum" [online]. 25 November (Prague: Radio Free Europe/Radio Liberty). Available from: http://www. rferl.org/content/article/1105122.html [Accessed 15 May 2019]

Transitions (1995) "Slow progress for CIS economics" Transitions, 25 February

Tutushkin, A. (2001) "Karachaganak spotknulsya o nalogi [Karachaganak gets stuck on taxes]" Vedomosti, 24 September

Varfolomeyev, O. (2014) "Ukraine readies to resume buying EU gas" Eurasia Daily Monitor, 14 March

Varfolomeyev, O. (2017) "Ukraine has gas for upcoming winter, but time for reform is running out" Eurasia Daily Monitor, 1 November

Vedomosti (1999) "Gazprom postroit gazoprovod iz Irana v Armeniyu [Gazprom will build a pipeline from Iran to Armenia]" Vedomosti, 16 November

Verezemskii, S. (1997) "Dobro pozhalovat' v 'kavkazskii gazovyi koridor' [Welcome to the 'Caucasian gas corridor']" Neft' $i$ Kapital, October

Verkhoturov, D. (2006) "Karashagynak: vynuzhdennoe reshenie 'Gazproma' [Karashagynak: Gazprom's forced decision]" APN Kazakhstan, 5 October

Victor, N. and Sayfer, I. (2012) "Gazprom: The struggle for power" in Victor, D.G., Hults, D.R. and Thurber, M. ed., Oil and governance. State-owned enterprises and the world energy supply (Cambridge: Cambridge University Press) pp.655-700

Vignanskii, M. and Grivach, A. (2005) "Gaz s ubezhdeniyami [Gas with convictions]" Vremya novostei, 22 November, p.7

Vinogradova, O. (2014) "Neft' i gaz Kryma: Poteri i priobreteniya [Crimea's oil and gas: Losses and acquisitions]" Neftegazovaya vertikal', No. 8, pp.4-7

Vinogradova, O. (2015) "Gazovyi revers Ukrainy [Ukraine's gas reverse]" Neftegazovaya vertikal', No. $17-18$, pp.26-30

Vinogradova, O. (2017) "Tsennik Gazproma ocharoval evropeitsev [Gazprom's price tag charmed the Europeans]" Neftegazovaya vertikal', No. 1-2, pp.44-49

Voloshin, G. (2016) "Gas-rich Turkmenistan looks to export diversification" Eurasia Daily Monitor, 8 April

Watkins, E. (2011) “Turkmenistan claims supergiant gas find” Oil \& Gas Journal, 13 October

Wyzan, M.L. (1999) "Mixing oil with politics" Transition, 15 March

Yafimava, K. (2007) Post-Soviet Russian-Belarusian Relationships. The Role of Gas Transit Pipelines (Stuttgart: ibidem-Verlag)

Yafimava, K. (2009) "Belarus: The domestic gas market and relations with Russia" in Pirani, S. ed., Russian and CIS Gas Markets and their Impact on Europe (Oxford: Oxford University Press for the Oxford Institute for Energy Studies) pp.133-169

Yafimava, K. (2010) "The June 2010 Russian-Belarusian gas transit dispute: A surprise that was to be expected", Oxford Energy Paper [online] NG 43 Available from http://www.oxfordenergy.org/2010/07/the-june-2010-russian-belarusian-gas-transitdispute-a-surprise-that-was-to-be-expected/ [Accessed 15 May 2019]

Yafimava, K. (2011) The Transit Dimension of EU Energy Security (Oxford: Oxford University Press for the Oxford Institute for Energy Studies)

Yafimava, K. (2015) "Evolution of gas pipeline regulation in Russia: Third party access, capacity allocation and transportation tariffs", Oxford Energy Paper [online] NG 95 Available from https://www.oxfordenergy.org/publications/evolution-of-gas-pipeline- 
regulation-in-russia-third-party-access-capacity-allocation-and-transportation-tariffs/ [Accessed 15 May 2019]

Yafimava, K. and Stern, J.P. (2007) "The 2007 Russia-Belarus gas agreement", Oxford Energy Comment [online] Available from http://www.oxfordenergy.org/2007/01/ the-2007-russia-belarus-gas-agreement/ [Accessed 15 May 2019]

Yakuba, A. (2007) “'Gazprom' produvaet truby [Gazprom blows the pipes]” Russkii kur'er, 14 May, p.9

Yenikeyeff, S.M. (2008) “Kazakhstan's gas: Export markets and export routes”, Oxford Energy Paper [online] NG 25 Available from https://www.oxfordenergy.org/wpcms/wpcontent/uploads/2010/11/NG25-KazakhstansgasExportMarketsandExportRoutes-Sha milYenikeyeff-2008.pdf [Accessed 18 May 2019]

Yermakov, V. (2018) "Shrinking surplus: The outlook for Russia's spare gas productive capacity", Oxford Energy Insight [online] (42). Available from https://www.oxforde nergy.org/wpcms/wp-content/uploads/2018/12/Shrinking-surplus-the-outlook-for-Russ ias-spare-gas-productive-capacity-Energy-Insight-42.pdf [Accessed 30 May 2019]

Yermakov, V. (2019) “It don't mean a thing, if it ain't got that swing: Why gas flexibility is high on the agenda for Russia and Europe", Oxford Energy Insight [online] (48). Available from https://www.oxfordenergy.org/wpcms/wp-content/uploads/2019/ 02/It-Dont-Mean-a-Thing-If-It-Aint-Got-That-Swing-Why-Gas-Flexibility-Is-Highon-the-Agenda-for-Russia-and-Europe-Energy-Insight-48.pdf [Accessed 30 May 2019]

Zhelenin, A. (2007) "Tsena gazovogo voprosa [The price of the gas question]" Nezavisimaya gazeta, 16 May, p.6

Zimin, D. (2012) "How can foreign companies influence Russia's economic course? The cases of Finnish firms Fortum and Neste", Post-Soviet Affairs, 28 (2): 209-231

Decree No. 1285 (11/09/2012) O merakh po zashchite interesov Rossiiskoi Federatsii pri osushchestvlenii rossiiskimi yuridicheskimi litsami vneshneekonomicheskoi deyatel'nosti [On measures to protect the interests of the Russian Federation when foreign economic activity is carried out by a Russian juridical person] (Moscow: President of the Russian Federation) 